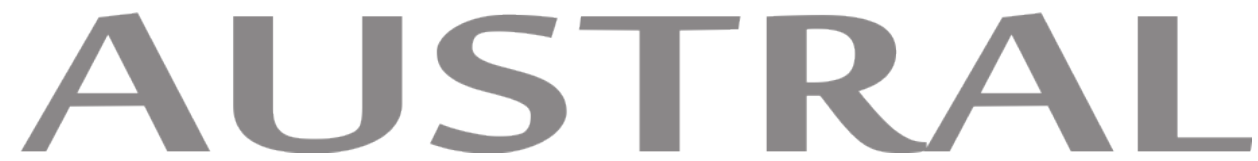

Revista Brasileira de Estratégia e Relações Interacionais Brazilian Journal of Strategy \& International Relations

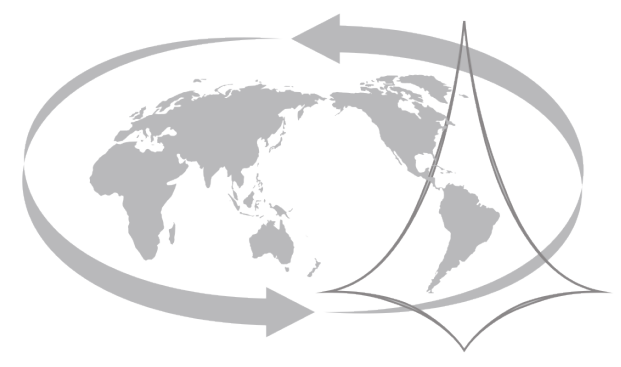

Porto Alegre, v.4, n.7 | Jan./Jun. 2015
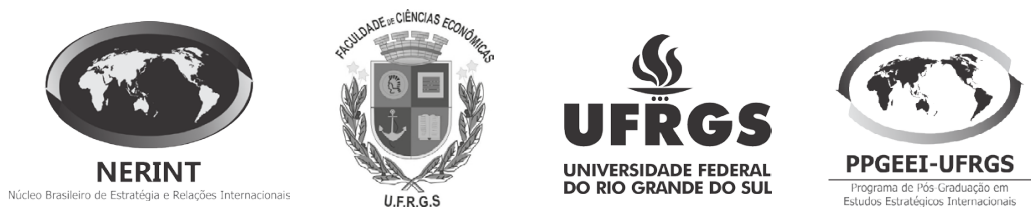


\section{Sobre a Revista}

AUSTRAL: Revista Brasileira de Estratégia e Relações Internacionais é um veículo essencialmente acadêmico, ligado ao o Núcleo Brasileiro de Estratégia e Relações Internacionais (NERINT) e ao Programa de Pós-Graduação em Estudos Estratégicos Internacionais (PPGEEI) da Faculdade de Ciências Econômicas (FCE) da Universidade Federal do Rio Grande do Sul (UFRGS). Seu foco plural busca contribuir para o debate da ordem política e econômica internacional a partir da perspectiva dos países em desenvolvimento.

A revista publica artigos originais e críticas a livros que estejam relacionados à vasta área de Estratégia e Relações Internacionais, com especial interesse em assuntos relacionados a países em desenvolvimento e à Cooperação Sul-Sul - seus problemas securitários; os desenvolvimentos políticos, econômicos e diplomáticos dos países emergentes; e suas relações para com as potências tradicionais - em inglês, português ou espanhol. O público-alvo da revista consiste em pesquisadores, especialistas e estudantes de pós-graduação em Relações Internacionais.

A revista tentará, através de sua política de publicação, assegurar que cada volume tenha ao menos um autor de cada um dos grandes continentes do Sul (Ásia, América Latina e África), de modo a estimular o debate e a difusão de conhecimento produzido nessas regiões. Todas as contribuições serão submetidas a uma avaliação científica.

\section{Indexadores}

Livre! | Latindex | ISN-ETH | Journal TOCs | Sumário de Revistas Brasileiras Beardsley Library Journals | Directory of Open Acess Journals

Columbia International Affairs Online

Este trabalho foi apoiado pelo

Programa de Apoio à Edição de Periódicos (PAEP) - UFRGS

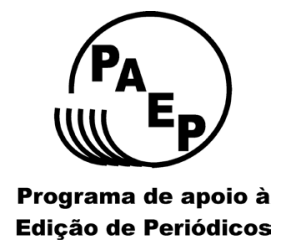




\section{Equipe Editorial | Editorial Team}

\section{Editor | Editor}

Paulo Visentini (Universidade Federal do Rio Grande do Sul, Brasil)

Editor Adjunto I Deputy Editor

Marco Cepik (Universidade Federal do Rio Grande do Sul, Brasil)

\section{Conselho Editorial | Editorial Board}

Celso Amorim (Ministério das Relações Exteriores / NERINT, Brasil)

Carlos Arturi (Universidade Federal do Rio Grande do Sul, Brasil)

Chris Landsberg (University of Johannesburg, África do Sul)

Eduardo Migon (Escola de Comando e Estado-maior do Exécito, Brasil)

Érico Esteves Duarte (Universidade Federal do Rio Grande do Sul, Brasil)

Fábio Morosini (Universidade Federal do Rio Grande do Sul, Brasil)

Gladys Lechini (Universidad Nacional de Rosario, Argentina)

Immanuel Wallerstein (Yale University, Estados Unidos da América)

Marcelo Milan (Universidade Federal do Rio Grande do Sul, Brasil)

Ruchita Beri (Institute for Defence Studies and Analyses, Índia)

\section{Assistentes de Ediçãol Edition Assistants}

Vitória Gonzalez Rodriguez (Universidade Federal do Rio Grande do Sul, Brasil)

Isadora Caminha Coutinho (Universidade Federal do Rio Grande do Sul, Brasil)

\section{Conselho Consultivo | Consultative Board}

Adam Habib (University of Johannesburg, África do Sul)

Amado Luiz Cervo (Universidade de Brasília, Brasil)

Analúcia Danilevicz Pereira (Universidade Federal do Rio Grande do Sul, Brasil)

André Luiz Reis da Silva (Universidade Federal do Rio Grande do Sul, Brasil)

Antônio Carlos Lessa (Universidade de Brasília, Brasil)

Antonio Jorge Ramalho (Universidade de Brasília, Brasil)

Beatriz Bissio (Universidade Federal do Rio de Janeiro, Brasil)

Bertrand Badie (Sciences Po, França)

Boris F. Martynov (Russian Academy of Sciences, Rússia)

Carlos Aurélio Pimenta de Faria (Pontifícia Universidade Católica de Minas Gerais, Brasil)

Cristina Pecequillo (Universidade Federal de São Paulo, Brasil)

Diego Pautasso (ESPM-Sul / Unisinos, Brasil)

Henry Kam Kah (University of Buea, Camarões)

Ilter Turan (Istanbul Bilgi University, Turquia)

José Ariosa Pérez (Universidad de la Habana, Cuba)

Liu Youfa (China Institute of International Studies, China)

Lotfi Kaabi (Institut Tunisien des Études Stratégiques, Tunísia)

Lucas Kerr de Oliveira (Universidade Federal da Integração Latino-Americana, Brasil)

Luiz Augusto Estrella Faria (Universidade Federal do Rio Grande do Sul, Brasil)

Luiz Rogério Goldoni (Escola de Comando e Estado-Maior do Exército, Brasil)

Mamoudou Gazibo (Université de Montréal, Canadá)

Marcos Costa Lima (Universidade Federal de Pernambuco, Brasil)

Maria Regina Soares de Lima (IESP, Universidade do Estado do Rio de Janeiro, Brasil)

Mehdi Parvizi Amineh (University of Amsterdam, Países Baixos)

Monica Hirst (Universidad Torcuato di Tella, Argentina)

Nikolai Mikhailov (Russkiy Mir Foundation, Rússia)

Sean W. Burges (Australian National Centre for Latin American Studies, Austrália) 


\section{AUSTRAL再或}

(C) Núcleo Brasileiro de Estratégia e Relações Internacionais - UFRGS

Arte da Capa: Vitória Gonzalez Rodriguez

Diagramação: Tiago Oliveira Baldasso

AUSTRAL: Revista Brasileira de Estratégia e Relações Internacionais está disponível online em: www.seer.ufrgs.br/austral

\section{Contato}

Universidade Federal do Rio Grande do Sul

Faculdade de Ciências Econômicas

Av. João Pessoa, 52 sala 33-A - $3^{\circ}$ andar - CEP 90040-00o - Centro

Porto Alegre/RS - Brasil

Fone: +55 51 3308.3963 | Fax: +55 51 3308.3963

E-mail: austral@ufrgs.br

www.seer.ufrgs.br/Austral

Cataloging-in-Publication (CIP)

Austral : Revista Brasileira de Estratégia e Relações Internacionais $=$ Brazilian Journal of Strategy \& International Relations / Universidade Federal do Rio Grande do Sul, Faculdade de Ciências Econômicas.

- v. 4, n. 7 (Jan./Jun. 20I5). - Porto Alegre:

NERINT/PPGEEI/FCE/UFRGS, 20I2-

Semestral.

ISSN 2238-6262. e-ISSN 2238-6912

I. Political Science. 2. International Relations.

3. International Politics. 4. Diplomacy. 5. Developing

Countries.

CDU 327

Biblioteca Gládis Wiebbelling do Amaral, Faculdade de Ciências Econômicas da UFRGS. 


\section{AUSTRALI歌 \\ Volume 4, Número 7 (Jan./Jun. 2015) \\ Sumário}

Editorial

Paulo Fagundes Visentini

Grande Estratégia: política externa e defesa em um mundo em transformação

Celso Amorim

As causas da $3^{a}$ Guerra Mundial: classe, geopolítica e hegemonia no século XXI - uma releitura de Arrighi, através de McDermott, Schumpeter e Veblen

Steven Colatrella

Relações navais entre Brasil e Reino Unido durante a Guerra Gria: o caso da aquisição das fragatas Vosper

João Roberto Martins Filho

Uma análise comparativa do imbróglio do Japão Imperial na China e do impasse norte-americano no Iraque pós-Saddam: similaridades, lições e implicações

Masahiro Matsumura

A emergência da periferia no Sistema Mundial: da Conferência de Bandung à Conferência de Buenos Aires (1955-1978)

Analúcia Danilevicz Pereira, Klei Medeiros

Política externa regional de Angola: mudanças frente à Ordem Sistêmica (1975-2010)

Igor Castellano da Silva

Reflexões sobre a Emergência Chinesa

Cesar Augusto Lambert de Azevedo

Desenvolvimento e a OMC: liberdade para quem?

Rafael Rosa Cedro

Do centro às periferias: o deslocamento ideológico da diplomacia da Santa Sé com o Papa Francisco

Anna Carletti 
Orden interno y política exterior argentina: la cuestión de los 240 biocombustibles

Cristian Lorenzo

$\begin{array}{ll}\text { Parceiros } & 260\end{array}$

Normas de Submissão / Números Anteriores 263

A responsabilidade do conteúdo dos artigos é de seus respectivos autores. The responsibility for the content of the articles is of their respective authors.

Austral: Revista Brasileira de Estratégia e Relações Internacionais e-ISSN 2238-6912 | ISSN 2238-6262| v.4, n.7, Jan./Jun. 2015 


\section{EDITORIAL}

\section{Paulo Fagundes Visentini ${ }^{1}$}

Dois anos atrás, nosso editorial se intitulou Brasil, o elo fraco do BRICS? $\left(\mathrm{n}^{\mathrm{o}} 4\right)$, e no ano passado foi denominado A Guerra Econômica e o silêncio da Academia $\left(\mathrm{n}^{\circ} 6\right)$. Para alguns leitores, pareciam análises exageradas. Todavia, a extrema polarização política das eleições brasileiras e os posteriores processos-relâmpago anticorrupção da Operação Lava a Jato, por um lado, e a acelerada deterioração econômico-financeira e diplomático-militar das relações internacionais, por outro, parecem conferir sentido a tais editoriais.

Os grupos de oposição brasileiros (e seus aliados externos), de fato, não aceitaram a quarta derrota consecutiva nas urnas em 2014 e buscam, por diversos meios, questionar a legitimidade do governo. As grandes empresas brasileiras internacionalizadas, o setor de energia e o de ciência e tecnologia foram bastante afetados, o que explica, em parte, a frágil situação econômica. No plano externo, a oposição parece tentar afastar a integração sul-americana, a Cooperação Sul-Sul e a participação no BRICS da agenda diplomática brasileira.

Enquanto ocorrem ataques especulativos contra a moeda brasileira e as Bolsas de Valores chinesas, a Rússia segue pressionada por sanções europeias e norte-americanas, inclusive perturbando a preparação do Campeonato Mundial de Futebol de 2018 nesse país. Por outro lado, na Europa, a questão do conflito ucraniano e da crise grega agora é secundária na agenda. O fluxo de refugiados, que cruzava o Mar Mediterrâneo, da desgovernada Líbia para a Itália, foi superado por outro ainda mais expressivo. Sírios, afegãos e outros caminham, em levas maciças, através dos Balcãs rumo à Alemanha e outras nações. Muitas regras da União Europeias parecem estar sendo suspensas,

I Professor Titular do curso de Relações Internacionais da Universidade Federal do Rio Grande do Sul. Doutor em História Econômica pela USP e Coordenador do Núcleo Brasileiro de Estratégia e Relações Internacionais. E-mail: paulovi@ufrgs.br. 
num movimento regressivo. E a Hungria, que em ig 89 demoliu a cerca que a separava do "mundo livre", às pressas construiu outra para impedir a entrada dos refugiados.

A intervenção e apoio a movimentos opositores no Iraque, na Líbia e na Síria constitui um dos fatores mais expressivos da origem dos problemas migratórios atuais. A chegada de centenas de milhares de pessoas da região, que o Ocidente classificava como vítimas, se transformou num tsunami humano durante as férias de verão do hemisfério norte. A Europa, então, se viu sem uma resposta e não pode impedir a chegada nem enviá-los de volta. Até fronteiras internas da União Europeia passaram a ser controladas, fato inédito em meio século. O surpreendente é que a Europa não esperava tais consequências e não tem a menor ideia do que fazer para resolver o problema.

Mais do que eventos isolados, esses acontecimentos fazem parte de um processo sistêmico. Para abordar tais questões, nesse número contamos, entre outros, com artigos do ex-Ministro Celso Amorim sobre o cenário da área de defesa, do pesquisador Steven Colatrella sobre os fundamentos teóricos da economia mundial e de uma virtual Terceira Guerra Mundial, além de análises sobre a Marinha do Brasil (João Roberto Martins Filho), o significado dos 60 anos da Conferência de Bandung (Analúcia Pereira e Klei Medeiros), a política externa de Angola (Igor Castellano) e sobre a inovadora Diplomacia do Papa Francisco I (Anna Carletti), além de outras importantes reflexões.

$* * *$

Agradecemos o apoio da Pró-Reitoria de Pesquisa da UFRGS, através do Programa de apoio à Editoração de Periódicos (PAEP) para tradução, edição e impressão, bem como a toda equipe que trabalhou na edição e tradução, em particular às Assistentes de Edição Vitória Gonzalez e Isadora Coutinho. Também somos gratos à Professora Cristina Soreanu Pecequilo pela revisão das versões em inglês. E, com satisfação, informamos que a revista AUSTRAL renovou sua Equipe Editorial, agregando nomes de prestígio, comprometidos com o projeto, iniciando uma nova fase. 


\section{GRANDE ESTRATÉGIA: POLÍTICA EXTERNA E DEFESA EM UM MUNDO EM TRANSFORMAÇÃO'}

\section{Celso Amorim²}

No dia 2 de janeiro de 20I4, um atentado a bomba em Beirute feriu 60 pessoas e tirou a vida de pelo menos cinco, entre elas a brasileira Malak Zahwe. A jovem Malak, nascida em Foz do Iguaçu, morava com a família no Líbano, e estava fazendo compras com sua madrasta quando a explosão ocorreu. Uma grande comunidade libanesa vive entre nós e um número crescente de brasileiros reside no Líbano. Temos uma ligação próxima e direta com aquele país. Como nos recordou o bárbaro atentado de janeiro de 20I4, essa ligação é, acima de tudo, uma ligação humana.

Situações trágicas como essa reforçam a compreensão de que somos parte da sociedade global. A indiferença frente aos desafios com que nos deparamos no estrangeiro não é mais cabível. Atitudes isolacionistas do tipo "não devemos nos meter em assuntos que não são nossos" revelam não apenas insensibilidade, mas também alta dose de irrealismo e incompreensão. Um dos efeitos da tão propalada globalização é que "todos os assuntos são nossos".

Temos um interesse claro na paz mundial, e devemos contribuir para preservá-la. Foi o que o Brasil tentou fazer, com êxito em alguns casos, e lançando sementes que germinariam mais tarde em outros. Atraímos Cuba para o Grupo do Rio e para a CELAC. Hoje aquele país convive pacificamente com todas as nações das Américas. Juntamente com a Turquia, empenhamo-nos em negociações com o Irã sobre seu programa nuclear que, quando menos,

I Texto baseado parcialmente em palestra proferida na Escola de Guerra Naval em I4 de maio de 2015 .

2 Diplomata brasileiro e ex-Ministro da Defesa. Ao longo de sua carreira, ocupou o cargo de Ministro das Relações Exteriores do Brasil. Pesquisador do Núcleo Brasileiro de Estratégia e Relações Internacionais (NERINT). 
demonstraram que havia campo para buscar soluções por meio do diálogo para a espinhosa questão do programa nuclear iraniano. Hoje, nos dois casos, felicitamos os avanços realizados pela maior potência do mundo.

Em outra ocasião, afirmei que o Brasil não deveria se contentar em ser um país pacífico, mas deveria buscar ser um país "provedor de paz". Para tanto, o Brasil deve adotar uma grande estratégia que conjugue política externa e política de defesa. Naturalmente, a diplomacia é a primeira linha de defesa dos nossos interesses. E o diálogo dever ser seu principal instrumento. Mas em um mundo em que o conflito está longe de ser extinto e as grandes potências frequentemente recorrem a ações unilaterais, a diplomacia deve ter o respaldo permanente da política de defesa.

Muito se fala do poder brando, desde que Joseph Nye, professor de Harvard e ex-secretário Assistente de Defesa, cunhou o termo. Trata-se de conceito inovador, que se aplica a muitas características do Brasil e seu povo, sua cultura e sua tradição de paz. Mas nenhum país se afirma no mundo somente pela atração de sua cultura e de seus hábitos. E há situações, como a que vivemos durante a II Guerra Mundial, em que o poder brando por si só não é suficiente para prevenir agressões ou incursões que afetem nossa soberania. Por isso, ao mesmo tempo em que cultivamos e exercitamos o nosso poder brando, devemos tratar de robustecê-lo. Nosso poder brando (soft power), expresso na capacidade de cooperar de forma mutuamente benéfica com outros países, será reforçado por nosso poder robusto (hard power), capaz de dissuadir ameaças e de tornar a colaboração com nossos vizinhos e parceiros, em matéria de defesa (por exemplo na proteção de recursos naturais) uma realidade.

A até aqui bem sucedida experiência no Haiti, em que contribuímos para restaurar a ordem naquele país, devolvendo ao povo haitiano a capacidade de decidir sobre o seu destino, é um exemplo de combinação de poder brando e poder robusto em uma situação em que não se tratava de uma ameaça imediata ao nosso país. No Haiti existia o risco, muito real, de que uma nação irmã, com a qual temos muitas afinidades - e que, afinal, não está tão distante de nós - caísse sob o domínio de bandos armados, uma combinação perversa de ex-militares golpistas e traficantes. Foi a propósito do Haiti que cunhamos (ou tomamos emprestado da União Africana, até hoje não estou certo) o conceito de "não indiferença".

A presença de uma fragata da Marinha do Brasil na componente marítima da Força Interina das Nações Unidas no Líbano, a Unifil, é outra ilustração de como o emprego de instrumentos militares pode reforçar a ação diplomática na busca da paz. Apesar das grandes dificuldades que o Líbano enfrenta, temos a certeza de estarmos cumprindo nossa responsabilida- 
de para com essa nação amiga. Além disso, reforçamos com nossa presença militar, os trunfos para uma eventual atuação politico-diplomática, quando as condições da região permitirem. Há uma ou duas décadas, a participação de um navio de guerra brasileiro em operações no Mar Mediterrâneo, um dos mais tradicionais tabuleiros da geopolítica mundial, seria vista como altamente improvável. Hoje, mesmo os críticos do envolvimento brasileiro em questões aparentemente distantes, como as do Oriente Médio, não parecem duvidar da importância de nossa contribuição à Unifil. Essa evolução não deixou de guardar relação com os impactos muito diretos da guerra de 2006 entre Israel e Líbano, na qual sete brasileiros morreram e três mil compatriotas foram evacuados por via aérea para o Brasil, em uma operação coordenada pelo MRE com o decisivo apoio de nossa Força Aérea. Eu estive em Beirute, no dia seguinte ao cessar fogo, e pude ver, com os meus olhos, o testemunho eloquente da proximidade entre os dois povos: camisetas da seleção brasileira e bandeiras do Brasil em meio aos escombros e destruição causada pelos bombardeios israelenses.

Nossa participação no Líbano, bem como nossa atuação diplomática em situações como as que levaram à “Declaração de Teerã” sobre o programa nuclear iraniano, e também o convite para participarmos na Conferência de Annapolis sobre o conflito Israel-Palestina ${ }^{3}$ sublinham a importância de refletirmos sobre nossos desafios e de definirmos nossos interesses. Temos de pensar sobre nosso papel no mundo sem complexos e com autonomia. A concepção de uma grande estratégia autenticamente brasileira - envolvendo política externa e política de defesa - resultará de um amplo diálogo público acerca de nossos desafios e prioridades, que envolve os meios políticos, diplomáticos e militares, com a participação da academia, da mídia, dos setores produtivos (empresários e trabalhadores) e da sociedade de modo geral. A publicação em 20I3 do Livro Branco da Defesa e de edições revistas da Política Nacional de Defesa e da Estratégia Nacional de Defesa deve ser vista como parte desse diálogo.

Muito já se escreveu sobre a natureza fluida da realidade internacional. Nos últimos anos do século XX, com o fim da guerra fria, passamos da bipolaridade para uma espécie de "unipolaridade consentida". Posteriormente, já no novo milênio, o mundo evoluiu para uma estrutura mista, que conserva traços da unipolaridade, mas que, em certos aspectos, se aproxima de um mundo multipolar. Ao mesmo tempo, vemos se desenhar, no horizonte, uma potencial nova bipolaridade, com a China assumindo, mutatis mutandi, o papel da antiga União Soviética, sem o fervor ideológico.

3 Trato desses dois temas em duas das narrativas do meu mais recente livro Teerã, Ramalá e Doha: memórias da política externa ativa e altiva (Benvirá, 20I5). 
Vivemos em um tempo de mudanças rápidas, profundas, mas marcadas por ambivalências. A emergência de novos atores e das chamadas "ameaças assimétricas”, frequentemente mencionada por estudiosos de defesa e de relações internacionais, não eliminou os antigos agentes na ordem mundial. E o conflito entre Estados não desapareceu de todo do horizonte. Mesmo em tempos de globalização econômica, os Estados nacionais guardam sua importância e a soberania segue sendo um princípio condutor. A "comunidade internacional" foi frequentemente invocada para justificar ações que correspondiam ao interesse de uma ou mais de uma grande potência. A "responsabilidade de proteger", consagrada em resoluções da ONU, foi invocada em situações em que o verdadeiro objetivo era a "mudança de regime" e não, como alegado, a "proteção de populações civis". O multilateralismo não superou a defesa de posições nacionais.

$\mathrm{Na}$ esteira da crise financeira global de 2008 , tomou corpo nos Estados Unidos um amplo debate acerca do suposto declínio de sua posição relativa no mundo. Eu mesmo, quando estive em Harvard por um mês, em uma fellowship da famosa Kennedy School of Government, depois de ter deixado a Pasta das Relações Exteriores, há quatro anos, pude assistir a várias discussões e debates em que o declínio relativo (ou não) dos Estados Unidos era um tema central para os próprios acadêmicos norte-americanos. Voltei àquela instituição após minha saída do Ministério da Defesa, em 2015, e verifiquei que o eixo da discussão mudou. Hoje, mais que a multipolaridade, é a ascensão da China, sua influência econômica e sobretudo sua estratégia de projeção marítima que despertam interesse e apreensão. A lógica do interesse nacional, mais do que qualquer outra, preside a definição de posições. É nesse quadro que se deve entender o estímulo a que o Japão retome um papel militar e estratégico, que havia sido abandonado após a II Guerra Mundial.

Em um mundo em que as ideologias perderam peso na definição das políticas nacionais, as coalizões de Estado, mais do que nunca, espelham uma geometria variável. Apesar dos esforços de Washington, os governos das grandes economias europeias não se furtaram a participar do Banco Asiático, liderado por Beijing. O antigo grupo das sete grandes economias industrializadas, o G7, evoluiu rumo ao G8, com a incorporação temporária da Rússia (mais por seu status nuclear do que por seu peso econômico), e daí ao G2o, que incluiu as economias emergentes e que foi definido pelo presidente dos Estados Unidos como tendo o principal papel (primary role) em temas econômicos e financeiros. O ressurgimento recente do G-7 não muda este panorama. E, na realidade, é um fato muito menos relevante do que a crescente coordenação entre os membros dos BRICS. Alguns autores passaram a achar que, com a gradual dissipação do excedente de poder da superpotência, esta- 
riam dadas as condições para um chamado "G-Zero", no qual nem os Estados Unidos poderiam liderar, nem os demais países estariam dispostos a seguir. Fareed Zakaria, entre outros, chamou a atenção para o que ele definiu como the rise of the rest ${ }^{4}$.

Quaisquer que sejam esses "Gs", temos hoje uma realidade complexa, que não se presta a modelos ditados pelo "pensamento único". Há amplo consenso de que estaria em curso uma desconcentração do poder nos campos político, econômico e cultural e, mesmo (talvez em menor grau), nos campos científico e tecnológico. A multipolaridade, mesmo que imperfeita, tem despertando esperanças de um mundo mais equilibrado e livre de hegemonias. Entretanto, no campo militar a unipolaridade continua, em larga medida, a prevalecer. Basta lembrar que os gastos com defesa nos Estados Unidos superam a soma das despesas militares de todos os demais países. Os avanços desse país em áreas como a cibernética não têm equivalentes em outras potências.

Apesar dessa superioridade, fatores psicológicos e sociais variados, sobretudo o crescimento da aversão às mortes de compatriotas, graficamente transmitidas pelos meios modernos de comunicação, reduzem as margens para a projeção do poder militar em outras regiões. Se a televisão contribuiu de alguma forma, com suas imagens cheias de tragédia sobre as vítimas do napalm, para apressar o fim da guerra do Vietnã, pode-se imaginar o que fariam as redes sociais, o twitter, etc. em uma situação similar nos dias de hoje. Daí a busca incessante de meios de destruição "sem risco" ou de baixíssimo risco como os drones e as ameaças de guerra cibernética. Mesmo formas menos avançadas de ataques com baixo risco foram aplicadas, por exemplo, nas operações militares contra a Sérvia, no Kosovo, onde os bombardeios aéreos eram realizados a grandes altitudes, o que impedia o discernimento preciso dos alvos. Tanto em um caso como em outro, os efeitos colaterais sobre populações civis são consideravelmente aumentados.

A exceção a essa aversão à exposição ao risco ocorreu apenas - e com as qualificações acima - em situações em que a segurança do próprio povo norte-americano foi percebida como diretamente ameaçada, como ocorreu no ir de Setembro. Apesar de toda a repulsa causada pelo chamado "estado islâmico", o número de sortidas aéreas contra os militantes do ISIS ou ISIL é infinitamente menor do que o que se verificou na segunda guerra do Golfo, que resultou na derrubada do regime de Saddam Hussein.

A suposição comumente compartilhada é a de que, em um "mundo pós-hegemônico”, as instituições internacionais criadas ao final da Segunda

4 Zakaria, Fareed. The post-American world and the rise of the rest. (Penguin Books, 2009). 
Guerra seriam mantidas. Com a provável superação dos Estados Unidos pela China como a maior economia do mundo nas próximas décadas, seria conveniente para todo o mundo e para os próprios Estados Unidos que Washington abandonasse a lógica do excepcionalismo e aderisse, de forma mais estrita, às normas de instituições multilaterais. As corajosas iniciativas do Governo Obama em relação ao Irã e a Cuba permitem algum otimismo, em que pese às resistências de setores mais conservadores norte-americanos.

Isso também traria benefícios para os demais países, assegurando-se certo grau de estabilidade às relações internacionais. Esses benefícios, entretanto, só serão plenos, no caso das nações em desenvolvimento, caso o compromisso com normas internacionais se faça acompanhar de reformas efetivas do processo decisório dessas instituições, a começar pelo Conselho de Segurança da ONU. Mas em relação a esse tema, a oposição maior parece provir não tanto da ainda maior potência - que mantém uma posição ambivalente sobre a ampliação - mas de outros quadrantes, inclusive da China, nossa sócia nos BRICS, o que mais uma vez sublinha a complexidade das relações entre Estados no mundo contemporâneo.

Em artigo recente, Kofi Annan e Gro Harlem Brundtlands fazem uma proposta de compromisso interessante: mandatos de longa duração, com os membros de longo mandato reelegíveis indefinidamente. Mas mesmo essa solução intermediária parece de difícil adoção no curto e médio prazo, uma vez que ela implica reforma da Carta de São Francisco, o que requer a ratificação das eventuais emendas por 2/3 dos Estados membros, inclusive os chamados P5. Um G-20 que passasse a se ocupar também de temas relativos à paz e a segurança internacionais - sem prejuízo da retenção pelo CSNU do poder último de decisão - parece oferecer a melhor esperança de um maior grau de descentralização da ordem internacional, injetando "ar fresco" nas discussões sobre tais temas.

Em relação à situação do Oriente Médio, as principais potências pareceram, em certo momento, entender a importância de uma participação mais ampla de países de várias regiões, inclusive nações em desenvolvimento. O convite de Washington a que Brasil, Índia e África do Sul participassem da Conferência de Annapolis, em dezembro de 2007, ilustra esse tipo de entendimento. Evidentemente, arranjos informais como o do G-20 não podem substituir a necessidade de um Conselho de Segurança reformado, que deve continuar a ser um objetivo estratégico da política externa brasileira, com reflexos na política de defesa. A reforma do CSNU é, necessariamente, parte integrante da "Grande Estratégia" do Brasil.

5 Disponível em: http://www.nytimes.com/2015/02/o7/opinion/kofi-annan-gro-harlembruntland-four-ideas-for-a-stronger-un.html?_r=o 
Os autores que admitem a retração (absoluta ou relativa) da hegemonia norte-americana apontam as contradições que ela envolve. O envolvimento político e militar da superpotência em múltiplos conflitos e crises ao redor do globo, consequência da lógica de hegemonia global que resultou do fim da Guerra Fria, drenaria recursos indispensáveis a investimentos em outras áreas como o meio ambiente, a saúde ou a educação. Um menor envolvimento implicaria, por sua vez, revisão dos compromissos com vários aliados e, de forma geral, o desengajamento de uma série de teatros de operação. Dependendo do ponto de vista, uma evolução desse tipo pode ser vista como positiva ou negativa, mas teria implicações importantes para o ordenamento internacional.

Um ponto comum a essas teses, todas elas publicadas no âmbito do debate norte-americano, é o reconhecimento de uma tendência de redução, discreta, mas perceptível, de algumas das assimetrias que separam a superpotência dos demais Estados. O exame de algumas dessas teses "declinistas" reforçaria a leitura de que a redistribuição do poder mundial é fenômeno de alcance ainda imprevisível. Por ora, não é possível dizer se o novo ordenamento pós-unipolar se consolidará como multipolaridade, isto é, uma distribuição do poder mundial entre um certo número de Estados - ou agrupamentos de Estados -, em relativo equilíbrio, ou se, como aventado acima, tomará a direção de uma nova bipolaridade, desta vez entre os Estados Unidos e a China.

Olhando o mundo do nosso ângulo e, com o indispensável realismo, parece certo afirmar que ainda persistirá por algum tempo, senão uma realidade unipolar, ao menos uma mentalidade unipolar. $\mathrm{O}$ aspecto mais preocupante dessa mentalidade é que ela não é puramente descritiva ou analítica, mas traz embutido um elemento prescritivo do tipo "temos que aceitar a realidade e nos adaptar a ela”. Em outras palavras: caberia ao Brasil, segundo essa visão acanhada, continuar a desempenhar um papel secundário no cenário global, submetendo-se à estratégia da potência dominante e buscando, no máximo, extrair vantagens de uma associação subalterna.

Igualmente perigosa é a equiparação entre hegemonia e estabilidade. Na visão "hegemonista", que predominou no imediato "pós-guerra fria”, a estabilidade seria garantida por uma certa "dominação benigna”. Como a década passada demonstrou, a tese de que a hegemonia gera estabilidade é falaciosa. A invasão do Iraque e a subsequente desestabilização da precária ordem do Oriente Médio, em sentido contrário aos interesses da própria superpotência, inclusive com a expansão do terrorismo, são testemunho eloquente de que a hegemonia gera insegurança, não estabilidade.

Tucídides, em sua magistral narrativa da guerra entre os povos helênicos, já compreendia perfeitamente esse ponto. Logo no começo da Histó- 
ria da Guerra do Peloponeso, o historiador ateniense explica que a origem do conflito foi o alarme gerado em Esparta pelo excessivo acúmulo de poder em Atenas. Em outra parte da obra, Tucídides faz um esclarecimento de importância transcendente sobre o assunto, e válido até os dias de hoje: "Não culpo aqueles que desejam dominar, mas sim aqueles que se submetem muito rapidamente. É tão próprio da natureza do homem dominar aqueles que se submetem a ele, quanto o é resistir àqueles que o atacam" (IV, 6I). Essas palavras se aplicam com muita propriedade quando se busca explicar a oposição de vários Estados ao ataque ao Iraque em 2003. Tal oposição refletiu também preocupação com a integridade do sistema normativo da Carta das Nações Unidas, o qual proscreve o uso da força sem a autorização prévia e explícita do Conselho de Segurança (exceto em caso de legítima defesa, conceito que deve sempre ser interpretado de forma cautelosa e restritiva $)^{6}$.

A perspectiva histórica lança uma luz adicional à razão por que o Brasil passou a trabalhar incansavelmente, a partir do início da década passada, no sentido de estimular os incipientes elementos de multipolaridade do mundo contemporâneo. Não só do ângulo dos princípios, mas até do pragmatismo, o unilateralismo, estimulado pela hegemonia, trouxe consequências contrárias às desejadas. O objetivo da multipolaridade foi buscado pelo Brasil em diferentes frentes, como a alta prioridade atribuída à integração da América do Sul; o pleito pela democratização das instâncias decisórias das Nações Unidas; a busca de maior justiça nas negociações comerciais, na Organização Mundial do Comércio; e a articulação com novos parceiros do mundo em desenvolvimento, como os membros do IBAS e dos BRICS, mas também com países árabes e africanos. Desnecessário dizer que motivações econômicas, culturais e humanas também estiveram presentes, em graus diversos, nesses esforços. A multipolaridade, baseada em normas multilateralmente aceitas, oferece as condições mais propícias a que o Brasil defina com autonomia os seus interesses e leve a efeito uma grande estratégia que inclua não apenas a dimensão de um país pacífico, mas um país provedor de paz.

Atravessamos um período de transição entre a mentalidade unipolar, o risco de nova bipolaridade e a promessa da multipolaridade. É contra esse pano de fundo que se devem examinar as áreas dinâmicas de algumas das situações com potencial de conflito na realidade atual. Uma dessas situações refere-se às disputas sobre territórios marítimos ricos em recursos naturais na Ásia, em que diferentes Estados pleiteiam a extensão de suas jurisdições sobre espaços que se superpõem. Temos assistido a uma competição que envolve potências regionais, como a China, o Japão, a Coréia do Sul, as Filipinas,

6 Na iminência da II Guerra do Golfo, os defensores de um ataque militar utilizaram abundantemente a ideia, prenhe de implicações perigosas, de preemptive self-defense. 
o Vietnã e a Índia, além de potências extrarregionais, como os Estados Unidos. A evolução recente nessa área indica, em primeiro lugar, um esforço do Governo norte-americano em reorientar seu engajamento político-militar, no chamado "pivô para a Ásia".

Em editorial, importante jornal dos Estados Unidos apoiou as medidas do governo japonês na direção de maior flexibilidade no emprego de sua força militar e cobrou a formação de uma aliança de democracias na Ásia para contrabalançar - são palavras do editorial - a ascensão chinesa. A insuficiência na Ásia de mecanismos de criação de confiança, promoção de transparência e definição de regras comuns de conduta é um fato ponderável na análise da evolução daquela região.

Outra área, que é palco de grandes mudanças - nem todas de sentido positivo - é o Oriente Médio. A chamada "primavera árabe" despertou grandes esperanças de que vários países caminhassem para ordenamentos políticos mais democráticos, com maior participação popular. Mas com a possível exceção da Tunísia (e mesmo ela sujeita a violentas erupções terroristas que põem em xeque a capacidade do governo de enfrentar a atração de doutrinas fundamentalistas), o que se viu foi a degeneração do movimento democrático em conflitos faccionais, como na Síria, ou o retrocesso puro e simples em direção ao autoritarismo, como no Egito.

Despontaram, nos últimos anos, inquietações acerca do futuro do status quo territorial criado pelo famoso Acordo Sykes-Picot, entre a França e a Grã Bretanha, prevendo o fim do Império Otomano ao final da Primeira Guerra. Isso até poderia ser positivo, caso o encaminhamento das mudanças tivesse ocorrido de forma pacífica - o que é obviamente não é o caso. A famosa expressão de Marx de que a "violência é a parteira da História" aplica-se plenamente ao Oriente Médio, só que não em direção do progresso social e político, como preconizava o pensador alemão.

A possibilidade de que o mapa do Oriente Médio, tal como foi desenhado há aproximadamente um século, deixe de existir é vista mais com apreensão do que com esperança. Algumas das ações das grandes potências contribuíram fortemente para essa evolução. O apoio político e a concessão de armamentos a facções revoltosas alimentaram setores fundamentalistas, do mesmo modo que, no outro extremo, a ajuda militar a governos autoritários não estimulou a busca de soluções pelo diálogo.

Do outro lado da balança, o recente acordo entre os $\mathrm{P}_{5}+\mathrm{I}$ e o Irã cria uma expectativa positiva para o encaminhamento de certas questões como o futuro do Iraque e da Síria (e a correlata questão do autodenominado "estado islâmico"), não obstante os temores, por razões distintas, de alguns países da região como a Arábia Saudita e Israel. 
No Oriente Médio, fatores de ordem estratégica mesclam-se com interesses por acesso a recursos naturais e acentuam clivagens étnicas ou religiosas. Até há pouco, a Síria vinha sendo um microcosmo dessas tensões. Hoje, ela disputa essa posição com o Iraque, sem falar no Iêmen. $\mathrm{O}$ acordo patrocinado pela Rússia e apoiado pelos Estados Unidos em setembro de 20I3, que prevê a destruição do arsenal químico sírio, foi um sinal encorajador do espaço aberto à diplomacia. Pouca gente sabe, mas o enviado especial do Diretor da Organização de Proibição de Armas Químicas nessa importante missão, é um brasileiro, o Embaixador José Artur Denot Medeiros, que durante cinco anos foi nosso representante junto à OPAQ.

É comum ouvir-se, no caso da Síria, o conhecido (e correto) refrão de que não há solução militar para o conflito. Ao mesmo tempo, o comportamento das grandes potências, armando um ou outro lado da guerra civil, contrasta com essa propalada convicção pacifista. A desestabilização causada na Líbia e no Norte da África pela intervenção militar anglo-franco-americana contra o regime Gaddafi, em 20II, se insere no mesmo cenário.

Ao drama dos refugiados se soma o dos imigrantes. Embora a interferência externa no conflito sírio não tenha alcançado proporções similares, é preciso registrar que a conflagração naquele país já transbordou para países vizinhos, como ficou claro no atentado em Beirute que vitimou nossa compatriota Malak Zahwe.

A ameaça de um "estado islâmico" agressivo se estende do Oriente Médio até praticamente o Golfo da Guiné. Crises como a da Síria exigem uma postura de respeito às regras da $\mathrm{ONU}$ e de trabalho conjunto com todas as partes interessadas que possam ter influência sobre o processo político em curso, inclusive - no caso - o Irã. O que quero indicar é que, ao contrário do que muitas vezes vemos ser defendido, a intervenção estrangeira é um remédio que costuma atacar o paciente, e não a doença. A situação do Iraque pós2003, ameaçado por conflitos étnico-religiosos e pela proliferação de grupos terroristas tem sido uma triste demonstração disso.

Uma situação que evidencia a fluidez crescente na realidade internacional contemporânea é constituída pelos vastos espaços localizados fora da jurisdição nacional dos Estados soberanos ou nos seus limites, caso das profundezas oceânicas, das altas latitudes e do espaço sideral. Essas áreas não estão livres de pretensões de controle hegemônico (e não falo aqui de uma única superpotência) em detrimento de direitos de Estados costeiros ou da exploração segundo regras multilaterais de conduta. A abertura de novas rotas e as possibilidades de exploração no Ártico deram ímpeto à discussão do assunto. Um editorial do Financial Times observou, sobre aquela região, que, "por enquanto, a contenda por recursos permanece polida. Mas isso pode não 
durar, se as descobertas passarem à frente das regras do jogo". Obviamente, esse risco não se limita ao Ártico. Ele se estende a todos os pontos do planeta em que a disputa por recursos naturais tenderá a acirrar-se, à medida que cresce a demanda mundial. O Atlântico Sul, área do nosso interesse direito, não estará livre dele.

O espaço cibernético é outra dimensão em que é visível o engajamento com fins econômicos e militares por parte das grandes potências. Por estar ainda em seus princípios, a guerra cibernética ainda não é um fenômeno plenamente conhecido. Indaga-se já, porém, em analogia com as concepções vigentes à época da Primeira Guerra Mundial, se não se está criando um "culto da ofensiva cibernética". Essa impressão é reforçada por iniciativas como a decisão tomada por um importante país, a Grã Bretanha, no sentido de desenvolver capacidades de ataque (e não apenas de defesa) no campo cibernético. A abordagem franca do tema pelo Ministro do país em questão causou grande repercussão. Mas certamente Londres não é a única capital a perseguir essa via. O caso do vírus Stuxnet, que atacou o programa nuclear do Irã, deve ser estudado com cuidado, ainda mais quando se conhece a tendência, em certos círculos, de estender o conceito e o alcance da não-proliferação para o de "contra-proliferação".

Segundo alguns especialistas, novas tecnologias de guerra como a cibernética, mas também os veículos aéreos não tripulados, apagarão as distinções tradicionais entre "guerra" e "paz", "militar" e "civil", "estrangeiro" e "doméstico" e "nacional" e "internacional", com o potencial de inverter a lógica da aversão ao risco a que me referi antes. Mais amplamente, o que vai surgindo no horizonte é a possibilidade de que se instaure um estado de beligerância permanente entre países adversários, até porque as fronteiras entre a espionagem e a guerra não são definidas com precisão. Para David Rothkopf, editor da revista Foreign Policy, trata-se de um novo tipo de guerra, que chama em inglês de Cool War, por oposição à Cold War. Ao passo que na Guerra Fria a destruição mútua assegurada (significativamente conhecida como "MAD", na sigla em inglês) pelas armas nucleares evitava que as superpotências se atacassem, nessa nova guerra, um pouco mais 'quente' que a anterior, cada contendor poderia ser capaz de "atacar constantemente, sem desencadear uma guerra aberta”. Países como o Brasil não podem ficar indiferentes aos sinais de que essas linhas de pensamento venham a prevalecer.

O denominador comum das tensões territoriais na Ásia, dos riscos de fragmentação no Oriente Médio, da rivalidade nos fundos marinhos e da militarização do espaço cibernético, entre várias outras áreas fluidas do sistema internacional, é o potencial de se alastrarem globalmente, inevitavelmente afetando o Brasil e o nosso entorno, a começar pela América do Sul e o Atlân- 
tico Sul, no processo. Alguns desses elementos de tensão estão, naturalmente, mais distantes de nós, enquanto outros inspiram cuidados mais imediatos. Todos têm, contudo, repercussão sistêmica, e podem ser fatores de vulnerabilidade para os interesses brasileiros e de outros países sul-americanos, que nos interessa coletivamente proteger.

Um razoável equilíbrio do poder mundial é condição fundamental, ainda que não suficiente, para a manutenção da paz. Esse é um dos pressupostos da grande estratégia do Brasil, que combina poder brando e poder robusto na busca de prover a paz. Cumpre-nos estar adequadamente capacitados para defender nosso território, nossa população e nossos interesses. O objetivo dessas e de muitas outras medidas é garantir ao Brasil a posse, com domínio tecnológico, de meios que afastem ameaças e agressões que possamos vir a sofrer a qualquer tempo e originadas em qualquer quadrante.

Para defender, não basta dissuadir. É preciso também cooperar. Esse tem sido e deve continuar a ser o princípio básico da política de defesa no entorno estratégico brasileiro. Com os vizinhos da América do Sul, vamos aprofundando a confiança, a transparência e a visão comum dos objetivos de Defesa, bilateralmente e por meio do Conselho Sul-Americano de Defesa. A defesa da América do Sul é uma responsabilidade dos sul-americanos. É importante que, progressivamente, essa visão impregne as políticas de todos os países do nosso subcontinente. A recém-criada Escola Sul-Americana de Defesa (ESUDE), com sede em Quito, mas que atuará de forma decentralizada, é um grande passo para aprofundar e estender a cooperação tradicional que já temos com outras nações sul-americanas. Devemos levar essa cooperação a novas áreas, como as da indústria e da alta tecnologia, como a aeroespacial e a cibernética (o que já começa a ocorrer) bem como a países que, em virtude de seu desenvolvimento ainda incipiente, sejam mais vulneráveis a incursões de interesses extrarregionais.

Também no Atlântico Sul, são dignas de nota a cooperação que temos prestado à formação da guarda costeira e à capacidade naval de Cabo Verde e a assessoria que a Marinha está dando à União Africana, no que diz respeito à segurança marítima. A Marinha brasileira, de forma pioneira, estendeu a cooperação com a Namíbia e se tem feito presente nas discussões e exercícios relativos à segurança no Golfo da Guiné. E não é apenas por solidariedade, que também é relevante, mas por interesse direto do Brasil, porque por lá passa boa parte do nosso comércio com a África, principalmente do nosso suprimento de petróleo. Por meio da ZOPACAS7, unimos esforços para que nosso oceano seja uma zona de paz e cooperação, livre de armas nucleares e

7 A Zona de Paz e Cooperação do Atlântico Sul (ZOPACAS) foi estabelecida em I986, por meio da Resolução 4I/II da Assembleia Geral das Nações Unidas. 
de todo tipo de rivalidades estranhas ao nosso entorno.

O entendimento realista das necessidades de defesa do Brasil no mundo tem precursores insignes. Foi com grande presciência que Rui Barbosa, em obra de i896, ponderou que "a paz é a cláusula essencial do nosso progresso. Mas (...) a primeira condição da paz é a respeitabilidade, e a da respeitabilidade a força”. Ou, em terminologia mais atual: o poder brando deve estar apoiado no poder robusto.

\section{REFERÊNCIAS}

Amorim, Celso. 2015. Teerã, Ramalá e Doha: memórias da política externa ativa e altiva. São Paulo: Benvirá.

Nye, Joseph. 2004. Soft Power: The Means to Success in World Politics. New York: Public Affairs Press.

Zakaria, Fareed. 2009. The post-American world and the rise of the rest. London: The Penguin Books.

New York Times. 2015. Four Ideas for a Stronger U.N. February 6, 2015. http:// www.nytimes.com/2015/02/07/opinion/kofi-annan-gro-harlembruntland-four-ideas-for-a-stronger-un.html?_r=o

\section{RESUMO}

Nos últimos anos do século XX, com o fim da Guerra Fria, o mundo evoluiu para uma estrutura mista, que conserva traços da unipolaridade, mas que, em certos aspectos, se aproxima de um mundo multipolar. Em uma realidade internacional de natureza fluida, a emergência de novos atores e das chamadas "ameaças assimétricas" não eliminou os antigos agentes na ordem mundial, e o conflito entre Estados não desapareceu de todo do horizonte. Nessa conjuntura, a diplomacia deve ter o respaldo permanente da política de defesa. Para tanto, no caso brasileiro, o artigo apresenta que o país deve adotar uma grande estratégia que conjugue política externa e política de defesa, na qual o poder brando (soft power) será reforçado pelo poder robusto (hard power).

\section{PALAVRAS-CHAVE}

Grande Estratégia; Política Externa; Política de Defesa; Brasil.

Recebido em 11 de agosto de 2015. Aprovado em 2 de setembro de 2015. 


\section{AS CAUSAS DA $3^{\text {a }}$ GUERRA MUNDIAL: CLASSE, GEOPOLÍTICA E HEGEMONIA NO SÉCULO XXI - UMA RELEITURA DE ARRIGHI, ATRVÉS DE MCDERMOTT, SCHUMPETER E VEBLEN}

\section{Steven Colatrella ${ }^{1}$}

\section{Introdução}

Nos últimos meses, a política mundial rumou de uma ênfase nas questões da globalização para aquelas de geopolítica. Os anos entre o crash financeiro de 2008 e a Primavera de 2014 tinham sido dominados pelos temas da austeridade, confiança dos investidores, agências de classificação de risco, Governança Global e por uma oscilação gradual e incompleta dos compromissos militares norte-americanos em zonas de conflito. Mas desde que o golpe patrocinado por EUA-UE provocou a crise na Ucrânia, e com os conflitos em torno das Ilhas do Mar do Sul da China e o compromisso militar dos EUA renovado na Ásia Ocidental, a economia parece ter dado lugar à política. Assim, encontramos uma nova ênfase na competição geopolítica, na agressividade da OTAN, no conflito entre Grandes Potências e entre competidores hegemônicos.

Os eventos desde o início da crise na Ucrânia sugerem que as análises de Arrighi e Silver em Caos e Governança no Moderno Sistema Mundo, e de Arrighi em Adam Smith em Pequim estão sendo confirmadas: o declínio da hegemonia dos EUA e a ascensão de um bloco alternativo com a China em seu centro podem afinal se defrontar com a asserção do poder militar dos

\footnotetext{
I Professor de Relações Internacionais da John Cabot University em Roma, Itália. Autor de Workers of the World: African and Asian Migrants in Italy in the 199os. E-mail: stevencolatrella@ gmail.com
} 
EUA que pretende frustrar - ou quase encerrar - o ciclo de potências hegemônicas que Arrighi identificou pela primeira vez em $O$ Longo Século $X X^{2}$. Mas a própria possibilidade de tal ação estar em uma posição para terminar um ciclo secular e estrutural no próprio coração do sistema mundial moderno sugere que a contingência desempenha um papel, igualmente significativo ou eficaz em todos os momentos e lugares ${ }^{3}$. Isto significa que a identificação de quem são os atores-chave, quais linhas são falhas em suas alianças e blocos hegemônicos, e quais são as suas estratégias e as opções torna-se importante não só para a análise, mas mais urgentemente para nos permitir construir alianças, estruturas e estratégias alternativas que podem nos dar uma chance para tirar o mundo do abismo. Devemos prestar muita atenção para um tema que é central, mas não explorado em profundidade na obra de Arrighi. Este tema é a relação entre alianças de interesses de classe - incluindo facções particulares de interesse de classe - e as agências de poder estatal. Por este último não pretendo me referir necessariamente a um Estado ou interesse nacional totalmente unido por trás de tal Estado ou aliança (como nas formulações da escola realista). Ver as agências estatais como heterogêneas e constituídas por e em relação a interesses divergentes na sociedade pode nos ajudar a entender mais precisamente porque algumas estratégias prevalecem sobre as outras em vários momentos. Assim, o período anterior de mercados abertos e de globalização, com sua ênfase no comércio e de certa forma no desenvolvimento pacífico de um mercado mundial como um bem comum, de fato, está mais intimamente relacionado com o recente retorno de temores legítimos de uma guerra mundial do que aparenta em uma primeira vista. Irei mostrar mais sobre a forma como este argumento está relacionado com a análise de classe desenvolvida no início do artigo. A nossa abordagem é em direção a estratégias alternativas que poderiam tornar mais prováveis que movimentos, alianças de classe e Estados fossem ser capazes de desfazer as causas de uma terceira guerra mundial antes dessas chegarem a uma materialização horripilante.

O deslocamento para o discurso geopolítico em meados de 2014 foi mais notável na medida em que ocorreu quase imediatamente depois das declarações públicas do Presidente Obama nas quais afirmou que a atual potência hegemônica estava deixando para trás uma década de guerra (no Afeganistão, no Iraque e em outros lugares) e anunciou cortes significativos nos gastos militares ${ }^{4}$. Presumiu-se que todas essas mudanças eram parte de

2 Giovanni Arrighi, O Longo Século XX: Money. Nova York e Londres: Verso I994.

3 Ver a explicação do argumento de Marx em O 18 Brumário de Luís Bonaparte por Massimiliano Tomba, em Max Tomba, “Marx como o materialismo histórico. Re-lendo O Dezoito Brumário”. Materialismo Histórico, Vol. 2I, Nr. 2 (2013), pp. 2I-46.

4 Embora os formuladores da política dos EUA tenham enfatizado anteriormente o chamado 
uma nova ênfase na diplomacia encapsulada na declaração de Obama de que a nova norma dos EUA para a política externa seria "não fazer coisas estúpidas." Embora a explicação mainstream da mídia Ocidental para essa mudança seja a postura supostamente mais agressiva do Presidente Putin, da Rússia, em relação ao mundo, e a crise na Ucrânia em particular, podemos pelo menos dizer que esta narrativa é altamente contestada por interpretações alternativas dos fatos 5 . Podemos ir ainda mais além e notar que, a partir da expansão da OTAN na década de 1990 e início de 2000 até a derrubada do governo eleito em Kiev, tem sido os EUA e seus aliados da OTAN os que têm mostrado a maior vontade de provocar, e não a Rússia ${ }^{6}$. Ao mesmo tempo, o Mar do Sul da China tornou-se palco de tensões crescentes com a China fazendo reivindicações de soberania sobre algumas ilhas, algumas das quais são prováveis fontes de petróleo e outras que podem ser pontos de estrangulamento importantes das rotas marítimas. O primeiro-ministro do Japão, Abe, tem sido extraordinariamente franco em uma série de eventos internacionais, usando a retórica sobre a China e a necessidade de enfrentá-la, sendo pouco diplomático ${ }^{7}$. Outros países da região, incluindo o Vietnã e as Filipinas também têm expressado preocupação e deixaram claro sua intenção de reforçar suas forças navais na região para bloquear as ambições chinesas. O Japão iniciou um significativo reforço militar enquanto, ao mesmo tempo, fazia uma mudança em políticas realizadas a décadas, vendia suas armas para outros países (nomeadamente a Índia) e alterava a sua legislação para permitir que as suas forças pudessem ser usadas fora das suas fronteiras nacionais e de seu território marítimo. A Índia, por sua vez, tornou-se a maior compradora internacional de armas, comprando da Rússia, do Japão, dos EUA e da Eu$\mathrm{ropa}^{8}$. O novo primeiro-ministro da Índia, Modi, no decurso de um pequeno

"Pivot para a Ásia": ver “Observações do Presidente Obama para o Parlamento australiano" I7 de novembro de 2011 www.whitehouse.gov; A frase "Pivot para a Ásia” vem da então secretária de Estado, Hillary Clinton: Hillary Clinton, "Engajamento americano é vital para o futuro da Ásia” Foreign Affairs Novembro de 20 II.

5 Entre outros, John J. Mearsheimer, "Por que a crise Ucrânia é culpa do Ocidente: Os Delírios Liberais que provocaram Putin" Foreign Affairs, setembro / outubro de 20I4; Steve Weissman, "Conheça os americanos que realizaram o Golpe de Estado em Kiev" Reader Supported News 25 de março de 20I4; Steve Weissman, "Parte II: Conheça os americanos que realizaram o Golpe de Estado em Kiev" Reader Supported News o4 de abril de 2014.

6 Ver Mike Whitney: “Será que Putin apenas trouxe a paz para a Ucrânia?” em Counterpunch, Sept.5-7 de 20I4 http://www.counterpunch.org/20I4/o9/05/did-putin-just-bring-peace- to-Ucrânia / e Mike Whitney, "Uncle Sam Does Ukraine” Io de setembro de 2014, http://www. counterpunch.org/2014/09/Io/uncle-sam-does-ukraine/ entre outros.

7 “China's Disputes in Asia Buttress Influence of U.S.” Int. Herald Tribune Sept. 23, 20I0; "Shinzo Abe takes a dangerous gamble" Economist Jan.4, 2014

8 "India has learned to flirt with the world—and suitors everywhere are dazzled" Obsession 
período de três semanas entre o final do verão e o início do outono de 20I4, realizou reuniões de cúpula com os líderes do Japão, da China e dos EUA. A China e a Rússia, por sua vez, começaram a construir laços econômicos mais estreitos, fornecendo a base para o início de um sistema monetário que seria independente da zona do dólar`. Este acordo permite a livre troca de moedas no âmbito da Organização de Cooperação de Xangai. Ao mesmo tempo, as duas potências chegaram a um acordo sobre um grande gasoduto, planejado há muito tempo, da Rússia para suprir as necessidades chinesas, um ato que deixou os países da UE preocupados com as fontes de combustível para o inverno ${ }^{\text {Io }}$.

Independentemente do que isso objetivava, não era para fornecer confiança aos mercados, tranquilizando os investidores ou credores ou cumprindo os requisitos das agências de classificação de risco, temas que pareciam ter substituído a política nos últimos anos ${ }^{\text {II }}$. Durante décadas, os líderes do Ocidente tinham insinuado, e em algumas ocasiões afirmaram explicitamente, que a globalização e o livre comércio tornariam o mundo mais seguro e fariam com que grandes guerras fossem impensáveis. Esferas de influência política e hegemonia regional foram tornadas obsoletas, e talvez até o próprio interesse nacional per se. Estas teses eram duvidosas nos seus melhores momentos, mas eram dominantes no discurso político devido a tudo isso. Agora é a visão globalizada, supostamente atualizada, do mundo que parece tão ultrapassada quanto a ideologia da Guerra Fria parecia apenas I2 meses antes. O que tinha acontecido?

Giovanni Arrighi, em $O$ Longo Século XX demonstrou pela primeira vez ciclos seculares ao longo da história do capitalismo em que sucessivas potências hegemônicas teriam surgido, criado novas bases para a organização da produção capitalista, para os mercados, para as relações internacionais e para a distribuição de riqueza e poder. Esse livro termina com a hipótese de que a hegemonia dos Estados Unidos da América estava chegando ao fim, um declínio sinalizado como no passado pela crescente importância das finanças no lugar da produção e do comércio na economia dos EUA (o famoso

Sept.9, 2014

9 "Vladimir Putin's Asia-Pacific Economic Cooperation (APEC) Summit Speech: Trade in Rubles and Yuan Will Weaken Dollar's Influence” Global Research, November II, 20I4; "Moscow's 'Mr. Yuan' Builds China Link as Putin Tilts East” Bloomberg Sept. 24, 2014.

Io "Gazprom says unable to meet rising gas demand from Europe for now" Reuters September I7, 2014

II Ver a minha análise do conteúdo de classe da substituição aparente da economia para a política como uma regra em hieróglifos de Steven Colatrella, " Meet the Global Ruling Class: Telling the Players with a Scorecard" Counterpunch 24 de novembro de 20 II. 
"sinal de outono", de Fernando Braudel). Arrighi cria uma hipótese, ainda, que alguma potência asiática, naquele momento mais provavelmente o Japão, mas talvez com uma aliança com a China, continuaria a tendência da história capitalista de expandir a escala e a representatividade das potências hegemônicas no sistema mundial. Havia um porém, além da questão lancinante sobre o quão provável era um consórcio Japão-China no futuro próximo - embora Arrighi não tenha feito previsões, demonstrou, ao invés disso, como a diferença nas relações de poder entre os EUA e o Japão poderia ser um potencial obstáculo para a renovação do ciclo. O poder militar dos EUA como Estado hegemônico não era como a bastante relativa - na melhor das hipóteses - superioridade militar de potências anteriores, como os holandeses (que na verdade eram formidáveis principalmente através da sua capacidade de financiar outros exércitos, juntamente com algumas grandes inovações no treinamento militar) ou os britânicos (cujas vantagens militares eram de mobilidade - a Marinha -e devido ao seu acesso às forças armadas indianas em nome do Império Britânico e financiado pelos contribuintes indianos).

Ao contrário, a vantagem militar dos EUA era absoluta. No ensaio final na coleção Caos e Ordem no Moderno Sistema-Mundo, Arrighi e Beverly Silver destacaram o significado deste paradoxo: que a maior ameaça ao funcionamento cíclico normal do capitalismo mundial era precisamente o que parecia ter sido há muito tempo a sua vantagem, a sua proteção de todas as ameaças graves, ou seja, o poder do militar dos EUA. Essas forças armadas, caso as elites dominantes dos EUA decidam não seguir os precedentes e, ao invés disso, resistam a entrar em declínio por meio do financiamento da próxima potência hegemônica, presumivelmente a China, poderiam estar em posição de bloquear não só essa transferência do poder mundial como o poder militar poderia superar o poder econômico e a necessidade capitalista. Isso também implicaria lançar o mundo sobre o precipício e para o abismo do holocausto global e até nuclear. Este desenvolvimento paralelo, de declínio dos EUA, crise e agressividade militar, e do crescimento econômico chinês e sua candidatura hegemônica, foi o tema do trabalho final de Arrighi: Adam Smith em Pequim. Esse livro postulou que a argumentação de Adam Smith de que um verdadeiro sistema de mercado mundial, baseado no "jogo limpo", pode significar uma diminuição gradual das desigualdades estruturais do capitalismo, nivelar condições econômicas globais e domésticas, e dar base a um mundo multicentrado politicamente em que qualquer número de grandes países iria interagir no mercado como nominalmente iguais. Para Arrighi, a possibilidade no século XXI em termos concretos foi que, ao contrário do universalismo hegemônico dos EUA, a hegemonia chinesa pode significar um mercado mundial sem o domínio completo de uma única potência. Tal- 
vez, em vez disso, signifique maior flexibilidade para a soberania nacional de cada Estado-nação. Isso pode, por sua vez, fornecer a base para um programa que poderia ser atrativo para inúmeros Estados-nacionais que teriam uma participação em uma nova ordem que iria além da hegemonia dos Estados Unidos com o seu bullying e sua insistência ideológica na homogeneidade das organizações e das políticas sociais.

A partir deste breve e reconhecidamente simplificado resumo da análise de Arrighi, certamente podemos afirmar que uma explicação muito convincente e relevante para o que aconteceu ao longo dos últimos meses, enquanto escrevo este ensaio no final do outono de 2014 , é que dois desenvolvimentos interligados ocorreram: primeiro, que a China desenvolveu uma rede de Estados em cooperação através de projetos patrocinados por ela: com a Rússia, em particular, mas também através da frouxa aliança frouxa de países do BRICS (Brasil, Rússia, Índia, China e África do Sul); a Organização de Cooperação de Xangai (Rússia, China e países que fazem fronteira com elas da Âsia Central); através de influência na ASEAN e APEC ${ }^{12}$ e de relações bilaterais (China é o principal parceiro comercial da Índia, do Brasil, da UE, da Rússia e do Japão, entre muitos outros); e através de sua crescente influência na África ${ }^{13}$. Essa última é baseada em uma relação muito mais respeitosa e equitativa de comércio e investimento, ao invés do ajuste estrutural do FMI e da austeridade, das dívidas e da ajuda ocasional, como tem sido o caso com os EUA e com o Ocidente ${ }^{\mathrm{I}}$. A China, portanto, passou a afirmar a sua candidatura à hegemonia em algum momento no futuro ou então sua liderança de um movimento em direção a uma ordem mundial pós-hegemônica e multicentrada. Ela também começou a estabelecer um parâmetro essencial para essa ordem mundial, nomeadamente restaurar a soberania do Estado nacional no que tange as políticas nacionais e as políticas comerciais e econômicas como

I2 "China and Japan's Standoff in the East China Sea: It Could Get Very Ugly" The National Interest Novembro 25,20I4; Gilbert Rozman,"Asia for the Asians: Why the China-Russia Friendship is Here to Stay" Foreign Affairs Outubro 29, 20I4; "Russia ratifies Economic Union and readies trade in currencies other than dollar" The Examiner Outubro 3, 2014.

I3 Horace Campbell, "China in Africa: Challenging US Hegemony" Third World Quarterly, Vol.29, No.I, 2008,pp.89-I05; Howard W. French, China's Second Continent: How a Million Migrants are Building a New Empire in Africa New York and Toronto: Alfred Knopf 20I4; Dorothy Grace-Guerrero and Firoze Manji, eds., China's New Role in Africa and the South: A Search for a New Perspective Cape Town, Nairobi and Oxford Fahamu and Focus em Global South 2008.

I4 Na verdade, a resposta aparente do presidente Obama à presença da China em África, ao invés de continuar com a criação de seu antecessor, o Africom - o comando militar dos EUA para a África, é um plano de cinco anos e US\$7 bilhões de dólares para o fornecimento de eletricidade para o continente que ficou muito aquém do seu metas: "Obama plan to 'Power Africa' gets off to a dim start" Reuters , Novembro 28, 2014. 
os princípios da economia mundial. Em outras palavras, substituindo a globalização neoliberal e a governança global, que tem usado frequentemente os direitos humanos como uma desculpa para "intervenção humanitária”, e outros importantes aspectos do regime mundial liderado pelos EUA nas últimas décadas. Ao mesmo tempo, os EUA apresentaram uma vontade maior e mais agressiva de usar seu poderio militar para impedir a ascensão de qualquer eventual potência ou aliança de potências que pudessem competir consigo pela hegemonia e para bloquear quaisquer ligações mais estreitas, em particular no continente euroasiático, entre a China, a Rússia e a UE (ou, pelo menos, a Alemanha), que criaria uma esfera econômica mundial alternativa àquela controlada pelos EUA.

Portanto, não é difícil, nem de qualquer forma incorreto, concluir que o pior cenário identificado por Arrighi e Silver, meios militares para prevenir um mundo pós-Estados Unidos, deu um passo ou dois na direção de se tornar realidade no segundo semestre de 20I4. Uma hipótese do trabalho de Arrighi é que a China poderia vir a ser o centro de um bloco hegemônico alternativo e potencialmente maior fundado em uma base diferente para renovar o mundo capitalista, como já aconteceu no passado. Essa hipótese também parece confirmada pelas diversas ligações, redes e acordos que a China tem se envolvido com vários outros Estados-nacionais recentemente. Então, não temos de abandonar ou mesmo alterar ou criticar fortemente as teses de Arrighi-Silver.

O que temos a fazer é nos preocuparmos. Muito. Porque, como Arrighi e Silver deixaram claro, caso estes dois desenvolvimentos, força militar transformando hegemonia em mera dominância e bloqueando a renovação do ciclo hegemônico capitalista, e a crescente interligação de uma parte do mundo em uma ordem hegemônica alternativa, cresçam conjuntamente, estaremos acenando para uma guerra mundial em uma escala ainda mais catastrófica do que a das duas guerras mundiais do século XX.

Acredito, porém, que ao analisar mais precisamente uma série de perguntas intermediárias dirigidas a essas teses e à própria situação mundial, e ao identificar mais precisamente tanto atores quanto processos, podemos obter um melhor controle sobre uma série de questões fundamentais: em primeiro lugar, porque o perigo de uma guerra está surgindo agora? Por que não há cinco anos ou daqui a cinco anos? Por que está adquirindo esta forma em particular? Quem está se beneficiando da virada dos EUA em direção ao militarismo (ou a intensificação de um militarismo que sempre existiu, para ser mais preciso), quem é aliado de quem ou quem pode vir a ser? Quais são as condições em que a guerra é mais ou menos provável? Que possíveis cenários poderiam levar a consequências que implicam em qualquer uma das possibilidades a seguir: A hegemonia dos EUA renovada, mas em uma base dife- 
rente, menos perigosa ou violenta? O fim do neoliberalismo e das injustiças e desigualdades que estão em sua essência? Significativa influência chinesa ou russo-chinesa, ou mesmo liderança hegemônica, na mudança para um mundo com mais de um centro, mas com menos risco de guerra apesar disso? $\mathrm{Ou}$ até mesmo um fim, ou os primeiros passos, em direção a uma superação do capitalismo e a construção da base para uma ordem mundial diferente?

As respostas completas a estas perguntas estão, obviamente, para além do escopo deste artigo. Mas eu espero aqui fornecer um quadro para análise e intervenção que fará com que seja mais fácil para nós, no espírito do Dezoito Brumário de Louis Bonaparte de Marx, não cair na armadilha de exagerar o papel dos indivíduos ou pequenos grupos como agentes, nem de exagerar a natureza estática ou automática de processos de grande escala. Em particular, com a releitura de Arrighi, juntamente com outros pensadores sobre processos e atores sociais, e em particular reafirmando a relação entre classes, frações de classe, Estados e agências estatais e interesses e alianças políticas, tanto na política nacional como na internacional, espero lançar luz em por que esta crise ocorreu neste momento e nas circunstâncias e com a forma que ela tem. Espero, também, mostrar onde as fortes linhas de defesa e os pontos fracos podem estar em estruturas e arranjos institucionais, bem como em alianças que estão atualmente nos levando à crise mundial e à guerra mundial. Mais especificamente, ao enfatizar um modelo mais complexo de relações classe-Estado, e examinando isso no contexto mais amplo da política internacional e da ordem mundial, e espero que no espírito de Marx de mostrar o papel da contingência mesmo em processos reconhecidamente estruturais e de longo prazo, espero sugerir onde podemos olhar para encontrar respostas para como desbloquear o impasse sistemático de uma hegemonia ascendente versus domínio militar e encontrar mais opções. Ao mesmo tempo, espero ajudar a evitar apostas em falsas soluções ou aquelas que são as melhores maneiras de meramente adiar o acerto de contas (útil como postergar pode ser) e para mostrar por que este enraizamento de "ambos os lados" no crescente conflito pela hegemonia mundial, e por que um retorno à ordem mundial do livre comércio e da globalização neoliberal (digamos, o mundo da década de I990) como uma alternativa pacífica para o risco de uma competição entre Grandes Potências e de guerra não é uma opção; ao invés disso, temos de ver que aquela ordem mundial é em si uma das principais causas da Terceira Guerra Mundial.

\section{Estados e Classes}

Arrighi não coloca as questões de formação de classes e do conflito 
de classes no centro de O Longo Século XX, nem em Adam Smith em Pequim, embora as questões de conflito de classes desempenhem um papel mais explicitamente importante no último. Mas aqui estou menos preocupado com a explicação bastante prática de Arrighi que não se pode fazer tudo de uma vez ao se investigar um sistema mundial do que na questão prática de como as classes e Estados estão relacionados. Em particular, quem está no comando - a classe dominante ou as autoridades estatais? Quais são as relações entre estes dois assumindo que é possível distinguir um do outro? Eles são necessariamente complementares? Eles são conflitantes mas funcionais para as necessidades um do outro ou, pelo menos, são seus conflitos subordinados a um interesse maior comum tanto da supressão ou exploração das classes não-dominantes quanto de um projeto hegemônico no sistema mundial?

Arrighi aborda estas questões em uma base caso-a-caso em $O$ Longo Século $X X$, de modo que ao discutir, por exemplo, a hegemonia holandesa, ele deixa claro que o sucesso da Holanda foi que sua classe dominante de capitalistas teve que se comprometer com outros interesses que tinham acesso ao poder do Estado e com um movimento social a partir da base, na forma do calvinismo. Estas lutas no seio da sociedade holandesa deram aos governantes holandeses - tanto as autoridades estatais quanto os capitalistas, a experiência que eles precisavam para entender mais plenamente e mais profundamente e para desenvolver soluções para os problemas sociais enfrentados pelo sistema mundial no século XVII. Ele também faz o extremamente interessante e sugestivo comentário de que a proto-hegemonia de Veneza foi o mais próximo que já vimos de uma estratégia e lógica puramente capitalistas em um Estado hegemônico ${ }^{15}$ (bem como uma discussão do mesmo modo interessante e sugestiva de como Cingapura parecia na década de 1990 ter reproduzido o modelo de Veneza de estratégia capitalista de Estado). Arrighi faz a distinção entre duas estratégias que são baseadas em diferentes lógicas: uma territorial e uma capitalista ${ }^{\mathrm{I}}$. A ambiguidade é que ele nunca explicita especificamente de quem estas estratégias são: dos Estados ou das classes capitalistas. Ao nomear as várias fases do capitalismo em Veneza, Gênova, Holanda, Grã-Bretanha e Estados Unidos como hegemonias sucessivas que expandiram a escala e reformularam o conteúdo institucional do sistema capitalista mundial, Arrighi parece estar dizendo que são os Estados e os seus governantes que se aliam com uma base mais (estratégia capitalista) ou menos (estratégia territorial) perto da classe capitalista, de modo a ter máximo acesso ao capital móvel para uso e decidir sobre ou ter imposta a eles uma ou outra estratégia ${ }^{17}$.

I5 Arrighi, O Longo Século XX, p.34

I6 Ibid., p.34.

I7 Na verdade, em Adam Smith em Pequim, ele afirma explicitamente que "as duas lógicas se 
Ele, no entanto, argumenta que existe uma questão legítima a ser levantada, e que está sendo feita por vários teóricos com quem ele discute, que o resultado da fase mais tardia (pós-Reagan) da hegemonia dos EUA é o crescimento de uma maior autonomia das corporações globais até o ponto em que elas, e não os Estados, agora fazem as leis que este último deve respeitar ou sofrer as consequências, e não o contrário ${ }^{18}$.

Mas ao invés de permanecer lá, Arrighi deixa claro que o poder autônomo de interesses comerciais não-territoriais, em especial finanças, e de interesses de classe e organização de classe que operam para além do espaço físico no espaço de fluxos, pode ter crescido ao longo dos séculos em escala e poder, mas não é exclusivo à globalização, aos séculos XX e XXI, ou à fase de hegemonia dos EUA. Pelo contrário, tem sido contínuo e consistente, embora mudando constantemente em forma e conteúdo, em todos os 500 anos de história do sistema mundial moderno. Na verdade, citando Weber, Arrighi mostra que a combinação de unidades políticas mais ou menos comparáveis em dimensões e poder, e a mobilidade do capital operando fora ou para além da autoridade territorial desses Estados, cria um mercado mundial para o capital móvel a fim de que os Estados aumentem o seu poder em relação uns aos outros ${ }^{19}$. Assim, o que é considerado uma inovação da era da globalização é, de fato, uma constante e, na verdade, um dos pilares do sistema mundial moderno e sem dúvida o fator mais original que o distingue de qualquer um de seus antecessores históricos. Mas duas realidades adicionais atenuam o efeito do capital móvel: em primeiro lugar, a necessidade de capitalistas móveis para proteção por um Estado poderoso o suficiente para protegê-los ("intercâmbio político" ${ }^{2 \circ}$ e a realidade relacionada, ainda que diferente, que está no centro do projeto de pesquisa de Arrighi, nominalmente o papel central dos sucessivos Estados hegemônicos na organização do sistema capitalista mundial, transformando o seu conteúdo e aumentando em escala qualitativa os fatores a cada fase. Arrighi nunca afirma isto explicitamente, mas ele deixa fortemente implícito que o jogo final do sistema capitalista é o seu fim inevitável em um império mundial com base em um bloco ou Estado hegemônico

referem principalmente às políticas de Estado" em uma nota de rodapé, fazendo a distinção entre sua análise e a de David Harvey: Arrighi, Adam Smith em Pequim, p.212, n.2.

I8 Embora mesmo aqui, Arrighi parece advertir contra a levar este ponto de vista longe demais, como em sua crítica à abordagem de Toni Negri e Michael Hardt ao Império, em que "nenhum Estado nacional, nem mesmo os EUA, pode formar o centro de um projeto imperial." Arrighi, Adam Smith em Pequim, p.I75

I9 Arrighi, O Longo Século XX, p.I2; Max Weber, História Econômica Geral New Brunswick, New Jersey: Transaction Books, I981, pp.335-557.

20 Veja a abordagem diferente de Charles Tilly; Coerção, Capital e Estados Europeus AD 9901992 Oxford, UK and Malden, Massachusetts I992 
tão grande em escala e tão poderoso a ponto de ser capaz de incorporar o capital móvel dentro seu sistema de autoridade territorial, como um aspecto de si mesmo. Assim, enquanto o capital móvel e as escolhas estratégicas de classes capitalistas que operam no espaço de fluxos externos à autoridade territorial do Estado são cruciais para a compreensão das relações de poder no sistema mundial moderno, estes, na verdade, são o fator central para entender por que cada Estado é realmente aquele com o maior poder ou mais influência na formação do sistema mundial, determinando resultados, distribuindo riqueza e poder e determinando resultados históricos - um ponto que por si só já teria feito O Longo Século XX o livro mais importante sobre relações internacionais já escrito - as estratégias referidas por Arrighi são aquelas dos Estados capitalistas e de seus governantes. Ele e Beverly Silver estão interessados, em especial, naqueles Estados e governantes que se apresentam no palco mundial como possíveis potências hegemônicas em condições de fornecer uma liderança para uma coalizão cada vez maior de Estados, para um setor grande e decisivo da classe capitalista em todo o mundo, e para uma proporção cada vez maior da população trabalhadora do mundo ${ }^{21}$. Assim, questões políticas mais amplas, e não apenas oportunidades de lucros, ainda que por vezes decisivas na determinação de quem vence politicamente no nível nacional e internacional, são, para Arrighi e Silver (em especial na análise de Caose Ordem no Sistema Mundial) o foco de estratégias para a liderança hegemônica no sistema mundial. Estou, em outras palavras, bastante confiante de que ao discutir estratégias, Arrighi se refere a estratégias estatais para ganhar influência, poder e, por fim, a hegemonia no sistema mundial, não estratégias de classes capitalistas como tal.

Se este for o caso, e aqui eu não afirmo que, apesar da minha confiança sobre as intenções de Arrighi, que o caso é aberto e fechado, então as opções estratégicas disponíveis e realizadas por diferentes classes capitalistas que têm monopólio ou controle privilegiado do capital móvel no sistema mundial ou no interior de portadores de poder territorial (Estados), ou ambos, não são realmente explorados exceto implicitamente. Os banqueiros genoveses, difundidos em toda a Europa em suas feiras de Piacenza aliados com Portugal e Espanha, eventualmente escolheram a Espanha como sua "proteção", como um Estado favorecido mantido em uma "coleira" pelo mecanismo do endividamento estatal. O papel do padrão-ouro em manter o crédito da Grã-Bretanha e garantir o seu acesso privilegiado ao capital móvel é descrito por Arrighi como crucial para a hegemonia britânica e sua ascensão como o centro financeiro do sistema mundial até o início do século XX. Mas a de-

2I Esse último tema, da relação da população trabalhadora mundial, é mais proeminente em Arrighi e Silver Caos e Governaça no Moderno Sistema Mundial 
cisão, seja ela explícita ou implícita, do capital financeiro de permanecer na Grã-Bretanha e ver os seus próprios interesses como classe como tudo menos sinônimo dos interesses de Estado do Império Britânico (em uma maneira que nunca foi imaginável, por exemplo, no relacionamento Gênova- Espanha) não é explorado como tal. Isso é compreensível na medida que, mais uma vez, não se pode colocar tudo em um livro. Também não vejo isso como uma fraqueza na teoria de Arrighi. Mas eu vejo isso como uma agenda de pesquisa para se explorar, para além do escopo deste artigo, é claro. Mas a questão maior, notadamente das bases sobre as quais classes, algumas delas totalmente residentes (se não necessariamente exclusivamente ativa) dentro das fronteiras territoriais do Estado e algumas delas em grande parte fora dessas fronteiras, tanto em termos de residência de seus membros (famílias e proprietários individuais) e de suas atividades capitalistas (investimentos, comércio, crédito, emprego de trabalhadores, etc.) é hoje de importância para nós a fim de compreender o que acabou de acontecer.

Como, em suma, a tentativa de unir as classes dominantes do mundo em uma classe dominante global baseada no setor financeiro, investimento empresarial global, uma perspectiva comum (globalização neoliberal), instituições de governança global (FMI, OMC, G2O, etc.), encontros informais (Davos, Bilderberg) e a subordinação efetiva de praticamente todos os Estados do mundo a esses interesses e princípios filosóficos sob a orientação de membros desta classe (unindo essencialmente as elites políticas e econômicas em torno de uma perspectiva de classe comum) pôde falhar? Como e por que ela deu lugar a uma competição mais tradicional e explícita, se aproximando do conflito entre blocos hegemônicos alternativos, um liderado pelo atual poder hegemônico dos Estados Unidos e a maioria, ainda que não todos, de seus aliados da OTAN e alguns asiáticos, e um liderado pela China com a Rússia como um aliado e que se baseia em uma nova infraestrutura projetada ligando Eurásia, Oriente Médio e África, com alguns aliados em outros lugares? É claro que ao fazer esta pergunta, primeiro precisamos afirmar que a própria questão confirma a relevância da análise de $O$ Longo Século XX, de Caos e Ordem no Sistema Mundial de Arrighi e Silver e de Adam Smith em Pequim de Arrighi. Mas é igualmente claro ao fazer esta pergunta que temos de distinguir entre diferentes interesses de classe e seus diferentes relacionamentos com os Estados.

Em particular, os diferentes tipos de capitalistas, seus ambientes diferentes - político-culturais, geográficos e socioeconômicos- e as diferentes agências estatais dentro do mesmo Estado- precisam ser entendidos para incluir diferentes estratégias tanto no que diz respeito ao conflito de classes e políticas dos Estados internamente e, ainda mais importante para os nossos 
propósitos aqui, com relação às abordagens alternativas para o sistema mundial como um todo. Mas o que queremos dizer com capitalistas, em primeiro lugar? Aqui o argumento de Arrighi no Longo Século XX é muito interessante, e baseado em parte na pesquisa de outras pessoas para o processo de formação (capitalista) de classes. Classes capitalistas não permanecem iguais ao longo do tempo. Há uma "circulação de elites", em que as famílias que compõem os setores dominantes dos capitalistas em uma fase historicamente dão lugar a outras famílias ligadas a estratégias inovadoras e novas formas de atividade empresarial e de novas fontes de reprodução de lucros de geração em geração ${ }^{22}$. Os setores anteriormente dominantes, aqueles que tinham na geração anterior ao presente acesso privilegiado ou monopólio para as áreas mais rentáveis da atividade, depois dão lugar aos recém-chegados, mas tem em mãos uma enorme acumulação de capital disponível. Assim, como Braudel afirma e como Arrighi repetidamente e utilmente parafraseia, financeirização é "um sinal do outono", uma fase, ou seja, que, como a coruja de Minerva voa ao anoitecer. O capital acumulado pelas elites anteriores é disponibilizado para os novos setores mais rentáveis, assim a liderança da classe capitalista é sempre um híbrido: com um prestígio e influência residual das elites antecessoras que foram uma vez, ou cujos ancestrais imediatos já foram eles próprios os inovadores de novos setores da atividade comercial e com fins lucrativos, e um setor ascendente de novos capitalistas envolvidos e experientes nas novas formas de negócio e nas novas relações de classe decorrentes destes e que também influenciam estes, e que, portanto, estão em condições de estar afinados com os problemas enfrentados pela sociedade como um todo no presente, embora, naturalmente, dispostos a lidar com estes só em condições favoráveis aos seus interesses de classe.

Esta renovação cíclica também implica, e de fato histórica e empiricamente parece envolver, o surgimento de novas estratégias estatais e de novas potências. As novas atividades e classes capitalistas precisam de patrocinadores e protetores estatais e de uma relação privilegiada com um Estado ou coalizão de Estados e, do outro lado, qualquer Estado ou governante procurando apresentar-se como potenciais líderes do sistema mundial precisam de uma relação privilegiada com as atividades de negócios mais rentáveis e as classes mais poderosas de capitalistas móveis. Esta análise baseia-se parcialmente em uma constatação empírica do historiador Henri Pirenne ${ }^{23}$, mas também é semelhante à análise em um ensaio interessante de Joseph Schumpeter ${ }^{24}$

22 Arrighi, O Longo Século XX, pp.86-87.

23 Henri Pirenne, "The Stages in the Social History of Capitalism" American Historical Review, Vol. I9, No.3, Abril i914, pp.494-5i5.

24 Joseph Schumpeter, “Social Classes” em Joseph Schumpeter, Imperialism, Social Classes: 
e ao trabalho sobre a transformação da classe capitalista moderna na era das corporações por John McDermott ${ }^{25}$.

Pirenne deixa claro que as classes capitalistas ascendentes não são as mesmas que as que haviam predominado na fase anterior, mas sim se desenvolvem a partir de seu envolvimento em novas atividades comerciais e novas conexões na economia mundial ${ }^{26}$. Schumpeter está preocupado com o movimento para cima e para baixo na hierarquia piramidal da(s) classe(s) capitalista (e outras) e vê o movimento para dentro e para fora de uma classe como uma mera extensão disto, embora um que encontra maiores obstáculos (cultural, status, político-jurídico, etc.) no processo ${ }^{27}$. Mas, e este ponto vai revelar-se mais importante à medida que chegarmos a nossa própria conclusão sobre as reais e potenciais alianças de classe hoje, Schumpeter salienta que o declínio de uma classe inteira deve ser relacionado com o declínio de uma função social legítima e reconhecida com a qual é intimamente associada ou sobre a qual tem um monopólio ${ }^{28}$. Pois desde a crise financeira de 2008 , a classe de credores falhou abertamente no exercício da sua função privilegiada de fornecer crédito para o resto da economia. Mas outras classes têm indiscutivelmente aumentado em sua utilidade necessária socialmente.

McDermott, como Arrighi, Pirenne, Schumpeter e Braudel, argumenta que a família e não o indivíduo é a unidade de análise adequada para o estudo de membros individuais das classes. Mas McDermott afirma que uma mudança ocorreu por volta do final da década de i89o. Este período corresponde ao fim da Grande Depressão de i873-96 que no esquema de Arrighi é a crise sinalizadora da hegemonia britânica, e também da virada ao setor financeiro, que começa simultaneamente com o nascer do poder hegemônico sucessor dos Estados Unidos. Arrighi observa em O Longo Século XX que os negócios dos EUA e da Alemanha estavam cada vez mais sob a rubrica de grandes corporações empresariais que utilizam economias de escala e, em particular, a integração vertical para atingir essas economias, internalizando assim os custos de produção, bem como, e esta era a novidade da corporação,

Two Essays by Joseph Schumpeter Nova York: Meridian Books, I955.

25 Especialmente em John McDermott, Corporate Society: Class, Property, and Contemporary Capitalism Boulder San Francisco Oxford: Westview Press, I99I.

26 Pirenne, "As etapas", pp.494-495; pp.506-508. De acordo com Pirenne, as famílias capitalistas mais antigas movem-se para propriedade de terra e tornam-se aristocracias. Arrighi e Braudel enfatizam seu papel como financiadores mais tarde, mas a conexão pode ser mais clara em nossa categoria contemporânea do setor FIRE da economia: Finanças, Seguros e Setor Imobiliário.

27 Schumpeter, "Social Classes" p.I59.

28 Ibid. p. 136 and p.I67. 
os custos de transação (mercados) ${ }^{29}$. McDermott vê esse desenvolvimento em termos de classe, e de fato uma de suas vantagens como um teórico e historiador de agência econômica é ver processos, forças, instituições como sendo incorporadas em grupos de seres humanos organizados, como classes ${ }^{30}$. Assim, enquanto Arrighi se concentra, compreensivelmente, no desafio alemão para a Grã-Bretanha, demonstrando que a eficiência alemã de produção alcançada pela organização corporativa não constitui realmente a maior diferença no poder econômico entre a Grã-Bretanha e a Alemanha e, posteriormente, na internalização dos custos de transação, como no caso dos EUA onde as empresas poderiam tirar proveito do tamanho continental da economia, do território e da população e, assim, internalizar mercados em mais de um sentido, McDermott está interessado em outros dois fenômenos: primeiro, como forças de produção com conhecimentos técnicos estão incorporadas na estrutura de negócios da classe capitalista e o significado social e político de classe dessa integração de uma classe nos processos de outra, e, segundo, a transformação da classe capitalista, e com ela da própria propriedade, através da ascensão da corporação ${ }^{3 \mathrm{I}}$.

A corporação também deve ser compreendida em termos de classe, de modo a evitar reificação de uma forma organizacional. E a corporação é uma forma de organização da classe capitalista que supera a propriedade privada estritamente falando sob a forma de propriedade familiar ${ }^{32}$. Assim, o capital, a organização da atividade empresarial e o próprio comércio, bem como os produtos e processos (executado pelos gestores, profissionais técnicos especialistas e operários) são a propriedade comum da classe capitalista como um todo, organizada na "comunidade de negócios" composta pelos proprietários imediatos de estoque, mas mais importante, pelo conselho de administração, a comunidade de investidores, a imprensa comercial e outras partes relacionadas organizadas em instituições ligadas à empresa específica, à indústria ou indústrias nas quais estão envolvidos (assim, em muitos casos, os agentes reguladores destinam-se a fornecer um poder contrário às empresas privadas) ${ }^{33}$. Em suma, a corporação é a organização da classe capitalista

29 Arrighi, O Longo Século XX, p.282: “Em particular, a integração vertical de processos de produção e de troca - que se tornou a característica mais importante do regime de acumulação dos EUA - não desempenhou nenhum papel na formação e expansão do regime britânico do século XIX. “

30 McDermott, Corporate Society, p.54: "O elemento médio é a bareira de tecnologia na nossa sociedade..."

3I Ibid., p.2I and passim

32 Ibid., pp.4-6.

33 Ibid. p.II5. 
enquanto classe, e permite que a classe tenha uma flexibilidade similar a que existe para o capital dinheiro móvel como explicado por Braudel, Weber e Arrighi: membros individuais de uma família capitalista já não são obrigados a estar envolvidos diretamente na execução de uma atividade profissional ou organização específica, nem ser conectados ou bem informados sobre uma indústria específica, processo técnico de produção ou rede comercial, e de fato podem fazer escolhas de carreira nas artes, na política, no trabalho de base e assim em diante, uma vez que o valor da família não é mais mantido por sua atividade direta, mas como membros de uma organização coletiva, a classe capitalista. (Curiosamente, Marx analogamente viu a propriedade "privada" em cidades-estados gregas ou romanas como sendo o mero caso individual dos direitos de propriedade decorrentes da cidadania na cidade e como membros da classe dominante ou classes de proprietários dessas cidades, de modo que o que parecia ser uma característica individual de fato era um sinal de associação em um coletivo sem o qual a propriedade detida não era nem significativa nem possível) ${ }^{34}$.

De acordo com McDermott, que é cuidadoso para não forçar seu argumento para além do que a história documentada demonstra, mas quem, no entanto, fornece-nos uma leitura altamente sugestiva baseada na luta de classes, o ponto de virada foi a greve Pullman de I894 nos Estados Unidos. A greve, uma ação de solidariedade do Sindicato dos Trabalhadores Ferroviários organizada por Eugene V. Debs, parou toda a rede ferroviária dos Estados Unidos, derrotando as mais poderosas organizações capitalistas. Mas, mais ao ponto, o sindicato industrial, através da organização de trabalhadores como classe, manobrou a classe capitalista que foi dividida pela sua competição interna, tanto comercial como familiar. Organizados por redes familiares, e assim divididos em seus interesses, os capitalistas encontraram dificuldades em estabelecer uma frente unida contra este oponente novo, bem organizado e unido em um confronto massivo de força. Com o sindicato dos trabalhadores em controle das condições de trabalho e de circulação de mercadorias por via ferroviária- isso, em I894, antes que o motor de combustão interna, ou viagens aéreas, houvesse fornecido meios alternativos de entregar mercadorias para o mercado - a classe trabalhadora poderia controlar e usar o poder de veto sobre o transporte e circulação de bens produzidos e, assim, sobre as condições de produção e de trabalho de toda a economia capitalista nos EUA ${ }^{35}$.

34 Karl Marx, "Formações Econômicas Pré-Capitalistas" Nova York: International Publishers, 2000, p.73.

35 McDermott, Sociedade Corporativa, pp.65-67; mas a excelente descrição das implicações da Greve Pullman está em um trabalho anterior: John McDermott, A crise na classe trabalhadora e Argumentos para um novo movimento trabalhista Boston: South End Press, 1980, pp.69-98. 
A intervenção do exército, enviado pelo presidente Grover Cleveland (nascido na minha cidade natal), um defensor do padrão-ouro e do mundo do capitalismo hegemônico britânico, e seu advogado General Richard Olney, salvaram os capitalistas em um primeiro momento. Mas a lição foi aprendida: nunca mais poderia a competição intra-classe e a concorrência comercial sobre quotas de mercado ser motivo de divisão politica da classe capitalista em face a um inimigo comum unido. Em vez disso, a competição teve de ser utilizada para reduzir a unidade da classe operária e outros oponentes do capitalismo (incluindo pequenas empresas, agricultores, comerciantes, como demonstra McDermott), enquanto as relações de classe capitalistas tiveram que ser organizadas e sujeitas a um planejamento de acordo com os interesses de classe.

Este desenvolvimento, consubstanciado na corporação, que só parece ser uma forma de propriedade privada, enquanto na verdade é uma forma de coletividade, propriedade de classe, gerida a partir do interesse da classe capitalista como um todo, ou pelo menos no caso de cada uma das empresas dos setores relevantes dessa classe, fornece uma resposta a um paradoxo da ciência política moderna: notadamente, por que a classe dominante em uma sociedade capitalista, que é caracterizada nas últimas décadas pela política eleitoral, não tem o seu próprio partido político na maioria dos países? A resposta é que eles não precisam de um partido, eles têm a sua própria forma de organização de classe: a corporação. Mas a corporação acaba por ser tão complexa como um partido político, por ela também ser uma relação entre classes, e não apenas a organização de uma classe contra outras classes.

Como John McDermott demonstra, o tipo ideal de burocracia de Weber não se aplica a uma corporação, que em vez disso é melhor entendida como uma relação (o termo usado por McDermott é "forma corporativa"), uma relação hierárquica de poder e controle entre três classes: a classe capitalista que é agora entendida como sendo o Conselho de Administração, os CEOs e alguns outros altos cargos de administração, os principais acionistas (cujo papel é no entanto considerado mais passivo), e "partes interessadas", como a imprensa de negócios, gestores de topo nas agências reguladoras relevantes, investidores, agências de classificação de risco, etc.; a classe técnico-profissional que é composta em grande parte por atividades científicas, técnicas, intelectuais, de engenharia, matemática, software e outros conhecimentos relevantes para os processos de produção e de acumulação de valor de uma determinada corporação, conhecimento que nos tempos de Debs ainda estava em grande medida nas mãos de trabalhadores qualificados, e que historicamente estava nas mãos de artesãos e de guildas, mas que foram colocadas sob o controle da gestão depois da introdução do taylorismo (Administração Científica); e da classe trabalhadora. Enquanto a última é ainda a maioria so- 
cial numérica, se encarada como a empresa quer, como uma frente unida dos interesses comuns das outras duas classes, constituindo entre $20 \%$ e $30 \%$ da população economicamente ativa, a classe trabalhadora é em grande medida tornada inócua enquanto uma força poderosa na sociedade, uma vez que os trabalhadores estão sujeitos à concorrência no mercado de trabalho em condições em que eles estão cada vez mais desqualificados, mas onde uma classe detém o poder gerencial e outra o conhecimento técnico e científico necessário e a habilidade para fazer a economia moderna ser rentável.

Em relação ao controle da gestão, os conhecimentos científicos apenas momentaneamente ficaram juntos à própria gestão, uma vez que a separação do empresário proprietário ou gestor do processo de produção diário gradualmente deu lugar a gestão de capitalista qua capitalista, ou seja, como gerente do dinheiro e do ciclo de M-C-M'. Para a corporação, ao fazer a propriedade em capital coletivo, transformou essencialmente propriedade em créditos sobre fluxos de receita. Os capitalistas como o topo da administração são aqueles com a maior quota de longe, e com o papel principal na determinação - embora em um processo negociado com base nas relações de poder entre as classes em qualquer momento, lugar ou indústria dados - da distribuição a ir para as outras duas classes ${ }^{36}$. Como a manutenção da estabilidade política de classe, suas próprias regras em outras palavras, requer uma aliança com a classe técnico-profissional, cujas habilidades científicas e técnicas também são necessárias para a produção, circulação, mercantilização, financeirização e rentabilidade dos produtos de todos os tipos e para compensar a superioridade numérica e papel necessário na produção de valor da própria classe trabalhadora, uma parcela desproporcional provavelmente vai para esta classe para mantê-la fiel. Sua lealdade, além disso, é garantida pelo fato de que é, presumivelmente, apenas sob condições capitalistas que o seu trabalho, o que é de interesse intrínseco aos seus membros de classe - cientistas, médicos, desenvolvedores de software, advogados, e assim por diante -, pode ser realizado, e tão somente nas corporações este trabalho é possível ${ }^{37}$. Pelo menos esta é a nota relativamente pessimista da brilhante Sociedade Corporativa de McDermott de alguns anos atrás. Mais recentemente, ele também vê sinais de que esta aliança pode não ser tão sólida quanto parece ou como tem sido até agora. Mas mais sobre esse assunto mais adiante.

Para os nossos propósitos, três pontos devem ser destacados por ago-

36 McDermott, Sociedade Empresarial, p.87-89; veja a análise de agências de classificação de risco como parte da comunidade da classe capitalista que McDermott afima no livro de Timothy Sinclair, Os Novos Senhores do Capital: Agências Americanas de Bond Rating e a Nova Política de Solvabilidade Ithaca: Cornell University Press, 2005.

37 McDermott, Sociedade Corporativa, p.r37 
ra: em primeiro lugar, que a corporação oferece uma forma organizacional tornando a unidade da classe capitalista mais provável; segundo, que qualquer acordo capitalista, e a hegemonia de qualquer classe capitalista, deve ser entendida no seu contexto de relações hegemônicas, mas também problemáticas, com outras classes, no que Gramsci chama de "bloco histórico" - que é um arranjo ou "agregação" político-social-econômico-cultural na frase de Deleuze e Guattari. Em termos mais prosaicos, nos referimos a uma aliança de classes organizada em torno de uma visão particular de civilização que é consistente com a hegemonia de uma determinada classe capitalista e de uma determinada potência ou aliança de Estados para governar e dar forma ao sistema capitalista mundial; em terceiro lugar, que as empresas de base familiar, uma vez que as corporações alcançam a internalização dos custos de transação, operam dentro de uma economia de setor-dual em que estão sujeitas a forças de mercado que não são mais autônomas como na teorização de Adam Smith, mas ao invés disso são um instrumento de controle social sobre as empresas menores e os seus preços, como parte do processo maior de produção capitalista como um todo (como mostrado pelo próprio Marx em O Capital Vol. 3).

A unidade capitalista nunca é dada. A concorrência não é apenas um epifenômeno do mercado. Pelo contrário, mesmo uma leitura política do capitalismo, como a de Arrighi ou mesmo aquelas de Harry Cleaver ${ }^{38}$, Charles Perrow ${ }^{39}$, John McDermott, Dyson e Featherstone ${ }^{40}$, para citar alguns, envolve necessariamente a compreensão de capitalistas como estando em competição por poder, influência, valor, lucros, comando organizacional, controle, status e privilégios, ou, no auge do poder em si e do próprio sistema mundial, a hegemonia. Essa hegemonia é exercida sobre, e envolve a capacidade de dar forma e conteúdo para o sistema mundial como um todo. Mas a competição capitalista também não é sempre um jogo de soma zero, como Arrighi deixa claro. Em momentos-chave nos ciclos históricos de hegemonia, particularmente durante a expansão comercial (antes da contração comercial, que leva à fase financeira como um "sinal de outono" em cada ciclo hegemônico), a concorrência ocorre como de acordo com as regras. Estas regras de engajamento

38 Harry Cleaver, Reading Capital Politically Austin: University of Texas Press, I980.

39 Charles Perrow, Organizando a América Princeton: Princeton University Press, 2002 argumenta que a grande corporação moderna surge por razões de controle político - sobre os mercados, pequenas empresas, indústrias e trabalhadores, não fora de qualquer maior eficiência econômica que encarna ou traz.

40 Kenneth Dyson e Kevin Featherstone, The Road to Maastricht: Negotiating Economic and Monetary Union Oxford e New York: Oxford University Press, I999, deixam claro que a UE como um projecto econômico e o euro foram concebidos e implementados por motivos estritamente políticos. 
são em grande parte as impostas pelo poder hegemônico da época (Veneza, Gênova-Espanha, os holandeses, os ingleses, os EUA) em formas institucionais, regulamentos jurídicos, costumes e práticas culturais, de modo que a coordenação e cooperação capitalista geralmente requer um poder hegemônico para fornecer um contexto no qual a competição pode ocorrer não como um jogo de soma zero, mas como um contexto ganha-ganha, em que a expansão signifique aumento dos lucros para a classe capitalista como um todo.

A corporação não é necessária para este processo per se, uma vez que Arrighi demonstra que esta fase se repetiu ao longo de séculos, muito antes dessas organizações existirem ou, ao menos, serem comuns. Mas uma forma organizativa claramente reduz custos de transação (até mesmo os banqueiros genoveses tinham o consórcio de San Giorgio) e faz que essa cooperação seja mais fácil. Podemos acrescentar que muitas das teorias de cooperação internacional, deixando de fora a dinâmica do capitalismo, suas diversas fases de desenvolvimento (como explicado por Arrighi), e qualquer conteúdo de classe ao decifrar os interesses envolvidos, reduz a questão da cooperação a um quebra-cabeça lógico aplicável pela teoria dos jogos ${ }^{4 \mathrm{I}}$. No mundo real prevalecem interesses reais, e aqueles interesses que são mais poderosos não são apenas aqueles de Estados, mas, como mostra Arrighi, de classes capitalistas ligadas a Estados ou em aliança com Estados, particularmente os hegemônicos. É aqui que os curtos ensaios de Schumpeter sobre Imperialismo e Classes vêm a calhar. Pois enquanto Arrighi está, sem dúvida, certo em desconsiderar a caracterização de Schumpeter de organizações pré-capitalistas como engajadas em conquistas sem qualquer motivo racional, o grande argumento de Schumpeter sobre imperialismos em tempos históricos é que eles são quase sempre ligados a um interesse de classe específico dentro da comunidade imperialista.

Nem interesses de classe análogos necessariamente levam aos mesmos resultados. Nem todas as classes agrícolas, nem todas as aristocracias, nem todos os interesses financeiros etc. são igualmente propensos a apoiar ou se opor ao imperialismo. Isso depende da socialização específica, formação, visão do mundo e, claro, especialmente, o ganho material - econômico, político ou territorial - que seria obtido da aventura imperialista, construção de império ou tentativas de ganhar hegemonia regional ou internacional. En-

4I Esta falta de uma análise de classe e de como a dinâmica de classe - interação intraclasse e interclasse - podem estar envolvidas são as principais limitações de trabalhos úteis e interessantes, tais como o de Robert O. Keohane, After Hegemony: Cooperation and Discord in the World Political Economy Princeton: Princeton University Press, 2005; e Elinor Ostrom, Governing the Commons: The Evolution of Institutions for Collective Action Cambridge Collective e New York: Cambridge University Press, I990. 
quanto Schumpeter desvia do que ao contrário seria um ensaio modelo de sociologia histórica por duas vezes - uma vez para fazer a reivindicação sobre a irracionalidade por parte de organizações não-capitalistas que trai a visão da Escola Austríaca do comportamento capitalista de mercado como o único racional, e na outra vez para abandonar completamente a narrativa histórica ao se empreender em uma discussão estritamente lógico-teórica de porque os capitalistas de mercado não teriam interesse no imperialismo - ele desenvolve para nós ferramentas úteis de três maneiras: I) ele mostra que o imperialismo está sempre ligado a um conteúdo de classe. Isso ajuda a entender tentativas de ganhar hegemonia, para defendê-la, ou - e aqui chegamos a principal prioridade do autor neste artigo - para encontrar uma ordem alternativa a ela e ao capitalismo como sistema mundial. Precisamos identificar, analisar, teorizar e desenvolver, na prática, bem como em programas de pesquisa, e organizar na política do mundo real, interesses de classe concretos como um "bloco histórico" ${ }^{2}$. Tal bloco histórico alternativo provavelmente veria vantagens para o seu próprio desenvolvimento e benefícios máximos em um abandono da hegemonia e do capitalismo; 2) Schumpeter mostra que o imperialismo exige algum apoio popular ou a opinião pública ao seu lado. Se não tem de ser uma maioria, não pode ser apenas o topo da classe de elite que apoia a construção do império. Portanto a necessidade de "dominância" dentro de uma comunidade hegemônica, bem como a nível internacional, ser combinado com a "hegemonia", com um grau de consentimento ou de liderança nos termos de Arrighi. Interesses de classe envolvidos em um projeto hegemônico podem, assim, não se beneficiar de um projeto como este no mesmo grau que a classe capitalista ou dominante ou interesses das elites que são a vanguarda de um projeto como este. Assim, um potencial ponto de fissura pode existir se um projeto tão ou mais convincente puder ser apresentado aos interesses de classe aliados com aquela parte da classe dominante que é hegemônica; 3) finalmente, que existe um interesse mundial e real da classe capitalista dominante no imperialismo, no militarismo e na expansão territorial. Esse interesse é o que Schumpeter chama de "exportação de monopólio".

Para ter certeza, Schumpeter insiste que o capitalismo moderno reduz a probabilidade de imperialismo, guerra e conquista porque: a) o capitalismo de mercado envolve um interesse comum no mercado como um bem público (para usar a linguagem de hoje), em outras palavras, ser parceiros comerciais beneficiam todos, cresce o "bolo" da economia mundial da maneira que Arrighi sugere durante a fase de expansão comercial de um ciclo hegemônico, e assim é criado um interesse na competição cooperativa que

42 Quintin Hoare, Geoffrey Nowell Smith eds., Selections from the Prison Notebooks of Antonio Gramsci Nova York: International Publishers, I97I, p.I37:. 
torna improvável e contra produtiva a guerra; b) a classe trabalhadora moderna também não tem interesse nem ganhos a partir de imperialismo ou o militarismo; c) há, portanto, pouco interesse por parte das duas classes dominantes do capitalismo, a burguesia e o proletariado, no militarismo, na guerra ou na conquista e no império. Mas Schumpeter também admite, retornando do mundo imaginário dos libertários (como eles chamam a si mesmos hoje) a construção lógica do modelo de mercado livre para o mundo real do capitalismo histórico, que "exportação de monopólio" constitui uma força material e interesse de classe real em impor sobre o poder do Estado o seu interesse em conquistar e garantir o acesso a recursos para as entradas de fornecimento de insumos, ganhando acesso ao monopólio e dominação sobre os mercados estrangeiros, e controlando fontes de força de trabalho.

Deve-se dizer que mesmo a exportação de monopólio - e é uma frase útil que nos leva a meditar sobre - não é sempre igualmente imperialista, tampouco somente competitiva e agressiva, ou imune a ver as vantagens da cooperação capitalista. Ao contrário, pode-se argumentar que a competição no mercado com igualdade de condições entre os tomadores de preço no sentido proposto por Adam Smith significa criar um bem público comum na forma do próprio mercado. Tal bem público requer alguma forma institucional para garantir seu contínuo funcionamento justo para o interesse de todos e sem nenhuma vantagem injusta para ninguém. Se tal condição já existiu, ela deve necessariamente ter sido altamente efêmera por razões esclarecidas por Karl Marx no capítulo 32 de $O$ Capital vol. I "A Tendência Histórica da Acumulação Capitalista”, e por razões sublinhadas por Karl Polanyi em A Grande Transformação é de fato para qualquer extensão real do tempo uma distopia impossível. Ao invés disso, para o grande capital de monopólio, a expansão dos lucros em um mercado em crescimento, onde os lucros são tirados do topo, por assim dizer, através de posições dominantes em pontos-chave do processo de acumulação e a cooperação com outros grandes interesses capitalistas, é vantajosa nesta fase a fim de evitar precisamente demasiada exposição às forças do mercado e para igualmente evitar guerras de preços entre as empresas monopolistas que seriam autodestrutivas para todos os envolvidos.

Alternativamente, os interesses comuns da elite capitalista que transcendem os interesses locais imediatos são mais suscetíveis de vir à tona neste momento. Como dividir os recursos, mercados preferenciais como esferas de influência (aqui a economia e a geopolítica quase se mesclam), jurisdição legal, regras e supressão das classes hostis, entre outras coisas, pode ter precedência quando o sistema como um todo está em uma fase de expansão. E a tal mini-fase mais recente foi a ascensão da globalização na década de I990 até o colapso econômico de 2008. Na verdade, e no quadro de Arrighi, 
essa expansão foi relativa, e um sub-fenômeno de uma expansão financeira maior, mas, mesmo assim, significou o aumento dos lucros e ampliação das oportunidades para a criação de lucros para as corporações globais, capazes de capturar as atividades de negócios mais rentáveis em todo o mundo para dentro de suas redes. Esta competição-cooperação existe fora, e no comando, das forças de mercado. Estas últimas são, em vez disso, impostas hoje sobre as empresas menores - como fornecedores -, sobre os trabalhadores, agricultores, governos e em outras forças sociais e classes mais fracas. Esta competição-cooperação que une o grande capital tem sido a base material para a Governança Global, que em outro momento eu já defini como a tentativa de unir as elites econômicas e políticas do mundo em uma única classe e em unir esses interesses através do mundo, perpassando fronteiras nacionais e culturais.

Esse projeto agora desmantelou-se. A Governança Global falhou como um projeto e como uma classe. A estrutura corporativa permitiu aos capitalistas assemelharem-se mais de perto com o seu próprio capital móvel, capaz de se mover além das limitações de sua própria família, origens étnicas, culturais ou nacionais, criando novamente uma base material experimental para unir os capitalistas e as elites políticas a nível global. Mas quando a expansão de oportunidades de investimentos lucrativos se contrai, quando os mercados encolhem e os lucros são ameaçados, a corporação global e o capital financeiro móvel também se tornam paradoxais: por um lado cosmopolita, globalista, sem fronteiras, e por outro lado capaz de usar de acesso privilegiado ao poder do Estado que, se alguma coisa, foi reforçado pela relação mais próxima com as elites políticas forjadas ao longo período (mais sobre este processo abaixo). Eles são, portanto, mais propensos a entrar em conflito com outros interesses análogos que estão intimamente ligados a outros interesses de Estado e que podem vir a ver maiores oportunidades de lucro em uma ordem alternativa em que o seu poder de monopólio inclui acesso monopolístico a Estados poderosos e acesso privilegiado a território, recursos e fontes de força de trabalho. Nesse caso, somos jogados de volta ao velho conflito hegemônico entre poderes concorrentes. Estas são as principais causas da Terceira Guerra Mundial.

Arrighi mostra, por exemplo, que não eram os interesses financeiros norte-americanos em Wall Street que apoiaram o que se tornou a estratégia vencedora dos EUA para uma eventual hegemonia: o protecionismo, a integração vertical por corporações e a exportação a partir de uma posição forte. O setor financeiro, ao contrário, demandava constantemente uma política de livre comércio, uma maior integração e apoio ao regime padrão-ouro con- 
trolado pelos britânicos ${ }^{43}$. Foram, ao contrário, corporações industriais que adotaram a estratégia vencedora, bem como o grande agronegócio necessário para manter os mercados de exportação após a Segunda Guerra Mundial. A política da Guerra Fria de Truman forneceu a estrutura necessária para alcançar a infusão contínua de liquidez sob a forma de dólares norte-americanos, que continuou até I973, quando viu o fim negociado (embora o final real foi dois anos depois) da Guerra do Vietnã, coincidindo com a primeira crise do petróleo ${ }^{4}$. Ainda assim, como Polanyi deixa claro, o setor financeiro tinha sido uma força pacificadora ao menos entre as potências europeias durante a paz de cem anos ${ }^{45}$ que se seguiu à batalha de Waterloo sob a hegemonia britânica, mas esse mesmo poder - das finanças sob a indústria enquanto interesse de classe na Inglaterra - ao mesmo tempo foi a base, junto com a posição britânica de entreposto mundial, da hegemonia britânica e de seu império territorial. Resumindo, interesses de classe análogos podem ser a base social de política divergentes no que tange expansão imperial e candidatura hegemônica. O setor financeiro norte-americano antes da Segunda Guerra Mundial e mesmo no mundo pós-guerra não foi a base da hegemonia estadunidense, de sua política na Guerra Fria, ou de seu complexo militar-industrial. Mas desde a "virada financeira" de outubro de I979, quando o presidente do FED, Paul Volker, aumentou drasticamente os juros, e especialmente desde o fim da Guerra Fria no início dos anos I990, o setor financeiro baseado nos EUA, mas crescentemente globalizado, tem sido um dos pilares principais da hegemonia norte-americana e da globalização enquanto política e da forma capitalista de expansão.

Corporações globalmente ativas, cujo apenas algumas são (e geralmente apenas nominalmente) baseadas nos EUA, tem um interesse em manter a globalização como uma forma de expansão capitalista. Mas quando os mercados diminuem, a competição começa a apertar e perder sua natureza de classe-cooperativa. As companhias, então, sentem-se "trabalhando para o público" - para utilizar da frase de Arrighi sobre os manufatureiros dos EUA durante a Grande Depressão de I873-96 quando os preços caíram continuamente junto dos lucros - e questões como controle de recursos naturais, (e logo) território, força de trabalho, fornecedores de matérias primas e poder trabalhista que se relacionam a esses territórios, começam a tornar-se importantes. Nesse ponto, companhias globais podem ou se direcionar ao Estado nacional com o qual elas são mais estreitamente associadas por origem nacional ou por atividade, ou elas podem ver os EUA e seus aliados como seus pro-

43 Arrighi, O Longo Século XX, pp. 294-5.

44 Ibid. pp.296-7

45 Karl Polanyi, A Grande Transformação, p.ıo 
tetores em escala global. A última opção foi, na minha visão, uma significante base para a Governança Global como uma forma de unidade global da classe dominante.

Mas vemos em retrospecto que essa estratégia teve dois lados: de um lado, ela uniu as classes dominantes do mundo na exploração comum dos trabalhadores e dos povos de todo o mundo, desenvolvendo uma cultura de classe comum baseada na "socialização das elites" 46 em Davos e na participação no G20, UE, OMC e outras cúpulas; ela também avançou uma ideologia cosmopolita em desenvolvimento que formalmente se opõe a identidades de raça, gênero, etnia, religião, nação e preferência sexual como bases de hierarquia entre as elites, enquanto deixava as desigualdades de classe crescerem a níveis sem precedentes. Por outro lado, a hegemonia dos EUA e a OTAN eram o guarda-chuva protetor sob o qual a classe dominante podia se assentar, adicionalmente assegurado por uma crescente integração dos setores mais abertos à globalização das elites financeiro-econômicas e elites políticas. Ainda que a distinção permanecesse entre as elites financeiro-econômicas e as elites políticas, crescentemente suas visões de mundo coincidiam ao redor da globalização e da hegemonia financeira como formas de civilização que não eram para serem questionadas ou criticadas.

Mas a mesma hegemonia dos EUA trouxe consigo o poder estatal estadunidense. Quando a competição deixa de ser amigável e cooperativa porque serve aos interesses de cada um no nível das elites globais, e, ao invés, se torna uma luta por recursos escassos - petróleo, água, território, fontes de alimentos, matérias primas para a maquinaria produtiva de um país ou para poderosas companhias globais competindo por acesso e correndo para um outro poderoso Estado para garantir a segurança dessas, o poder estatal dos EUA não será neutro. Especialmente porque essas condições são precisamente aquelas em que outros Estados vão estar ativos em se movimentar para garantir suas próprias bases econômicas, escorar as empresas com as quais têm uma relação privilegiada e estar dispostos a assumir mais riscos para realizar tais coisas. Os EUA, entretanto, com uma política de "domínio de espectro total", deixaram claro que não vão tolerar potenciais concorrentes pela hegemonia. Mais uma vez as relações são paradoxais, mas ainda mais perigosas por esse fato: a globalização tem diretamente extirpado grande parte da base manufatureira de dentro dos limites territoriais dos EUA, e simultaneamente difundido, pela primeira vez, a indústria mundial para o Sul Global, e,

\footnotetext{
46 Ernst Haas, A União da Europa: Forças Políticas, Sociais e Econômicas 1950-57 Stanford Univ. Press i968. Veja como eu expandi esse conceito em Steven Colatrella, “Em nossas Mãos está Colocado um Poder: Austeridade, Onda Mundial de Greves e a Crise de Governança Global” Socialismo e Democracia, vol. 25, no. 3 Novembro 20 II pp. 82-106.
} 
em seguida, concentrado esta grandemente dentro das fronteiras da China. Este processo levou, em especial desde a crise financeira asiática da década de I990, à ascensão da China como uma potência industrial, militar e cada vez mais tecnologicamente experimentada, ainda que atrás dos EUA e grande parte do Ocidente. Ou seja, a própria política de financeirização tem, como no passado, fornecido as condições para a emergência de uma potencial potência hegemônica sucessora aos EUA.

Pois as corporações industriais baseadas nos EUA eram primeiro corporações e segundo industriais. Para ser claro, esse resultado estava um pouco em aberto por um tempo: o crescimento de uma abordagem racionalista e tecnocrática à estratégia corporativa e à governança foi bastante proeminente na década de i950 e I96047. Foi precisamente após a financeirização do início dos anos i980 que começamos a ver os mercados financeiros, agora, intervirem na gestão das empresas com instrumentos como os pioneiros "junk bonds”, aquisições hostis, rebeliões de acionistas e outros movimentos para restaurar a natureza essencial capitalista qua capitalista (M-C-M') das corporações; estas foram restauradas para voltarem a serem vistas como piscinas de dinheiro que se desenvolveram em um determinado tempo e espaço para produzir ou realizar uma atividade específica, mas que cada vez mais não poderiam ser entendidas como definidas por esta atividade, nem por qualquer localização particular ou composição da força de trabalho (veja as discussões de David Harvey de como o capital cria ambientes e os destrói novamente quando seus custos superam sua rentabilidade). Assim, mesmo as companhias manufatureiras nos EUA têm cada vez mais dependido para lucros de seus próprios departamentos financeiros (como a GMAC para a General Motors) ao invés de suas vendas de produtos industriais.

Creio que aqui vemos os limites do quão longe a análise de Polanyi pode nos levar: este não é o livre mercado, como um mecanismo de autorregulação que requer que toda atividade esteja disponível no mercado e seja tratada como mercadoria (incluindo terra, trabalho e dinheiro como salienta Polanyi). Já não é mais "A necessidade de um mercado em constante expansão para seus produtos" (ela própria a fase que Arrighi define como "expansão comercial" em um ciclo histórico de hegemonias) que agora "persegue a burguesia por toda a superfície do globo". É, ao invés, o livre fluxo de capital-dinheiro que deve ser permitido "se aninhar em todos os lugares, se assentar em todo lugar, estabelecer conexões por toda a parte" ${ }^{4}$. E, uma vez que, como

47 Veja, por exemplo, Reinhard Bendix, Trabalho e Aurotidade na Indústria. Berkely: University of California Press, I974, p. 3I9 e pp. 308-34I

48 Karl Marx e Frederich Engels, Manifesto Comunista em Karl Marx. Londres: A Biblioteca do Colecionador de Pensadores Essenciais 2004, p. 25 
Arrighi deixa claro, a fase de financeirização, o "sinal do outono", em particular, envolve a transferência de capitais móveis da produção e comércio em dívida para o Estado, a dívida pública que é o epicentro dos esforços atuais para rentabilidade, com duas torções adicionadas à versão de hoje - o uso da dívida para desmontar o setor público (privatização) a fim de prover uma base material para futura expansão e lucratividade, e a extensão (globalmente) e intensificação (em dívida privada a larga escala, essencialmente transformando essa última em uma questão pública de política e composição de classe ${ }^{49}$ ) da penetração da dívida como uma forma de dominação de classe.

Qualquer Estado que não queira estar em débito com as finanças globais, qualquer Estado que rejeite condições (ou para usar o termo do FMI/ Banco Mundial, "condicionalidades") impostas pelos credores, que procure a moratória, a renegociação, ou proteja seus cidadãos, cidades e firmas das imposições mais custosas, ou que resista à privatização da maioria de seu setor público, que rejeite ou mesmo procure o compromisso de autonomia do banco central de autoridades governamentais (eleitas ou não), rapidamente sentirá a fúria do governo dos EUA, de seus aliados militares, das agências de risco, e transferências de capital móvel e "lacunas" de taxas de juros de investidores. Que tamanha dívida pública tenha sido constituída recentemente, quer em socorro aos bancos falidos durante a crise financeira de 2008-9, quer pelas guerras travadas pelos EUA, apenas sublinha as relações de poder vigentes. Quaisquer tentativas de fonte alternativa de crédito, ou mesmo de investimento, não vinculadas às classificações das finanças globais são vistas como hostis a este regime e seu aliado estatal, os EUA..$^{\circ}$

Junto desta forma claramente agressiva de finanças, que, longe de ser uma fonte de paz mundial como na época da hegemonia britânica, é um interesse de classe chave na guerra, vêm os outros fundamentos da hegemonia dos EUA nos últimos anos: o dólar como única moeda de reserva, a vasta rede de bases militares dos EUA ao redor do mundo e o recurso cujo controle é a base para diversas localizações da rede de bases, o petróleo. ${ }^{\text {I }} \mathrm{O}$ controle do petróleo, uma commodity que faz parte da produção de quase todas as ou-

49 Veja, por exemplo, Andrew Ross, Creditocracia e o Caso para Recusa da Dívida. New York: OR Books, 20I3.

50 Veja as atuais tentativas pelas cortes dos EUA para prevenir a Argentina de pagar outros credores que não os baseados nos EUA que o próprio país aplicou moratória em 200I. Veja também as tentativas para derrubar Hugo Chavez na Venezuela, um governo que se retirou do FMI, e a hostilidade em relação ao governo de Evo Morales na Bolívia.

5I Kevin Phillips, Teocracia Americana: os Perigos e Políticas da Religião Radical, Petróleo e Dinheiro Emprestado no Século XXI. New York: Viking, 2006 traça algumas das ligações entre finanças, o dólar, petróleo, guerra e políticas religiosas. 
tras mercadorias ${ }^{52}$, é uma grande prioridade política para os EUA ao redor do mundo e assim tem sido por muito tempo. ${ }^{33}$ Obter monopólio ou um controle monopolista eficaz de petróleo em todo o mundo permitiria aos EUA ditar os termos de desenvolvimento econômico e as relações de poder mundial para o futuro próximo. Isso também impediria qualquer grande mudança em direção a fontes de energia renováveis, que não poderiam ser facilmente controladas militarmente pelos EUA e pelas corporações envolvidas com petróleo e que estão intimamente aliadas aos EUA. Já que o petróleo vinha sendo, até recentemente, comprado e vendido apenas em dólares americanos ao redor do mundo, com seu preço cotado em dólares, o controle do petróleo e a posição privilegiado de monopólio dos EUA como única fonte de dólares ${ }^{54}$ ligava as finanças, o Estado americano, especialmente suas entidades mais poderosas como o Departamento do Tesouro e a Reserva Federal, e as forças armadas dos EUA ao petróleo. 55 Esse é o nexo de classe que é vinculado a uma forma de globalização financeirizada, agressividade militar, dívida como uma forma tanto de controle social e poder de classe doméstico quanto dominância global, e os meios de pagamento na economia mundial para o petróleo e a maioria das dívidas. O fato de que os EUA são o maior devedor do mundo não enfraquece esta estratégia na medida em que os EUA podem produzir dólares à vontade, ainda que fazê-lo em uma escala grande o suficiente significaria a ruína de seus principais credores, como China, Japão, Taiwan e a própria Wall Street eventualmente.

A base de classe da Governança Global não pode, portanto, ser entendida como tendo fornecido uma alternativa à hegemonia dos EUA na forma de política mundial multipolar, pluralidade global, ainda menos democracia global ${ }^{6}$. Ao invés disso, Governança Global como uma forma política tem

52 Veja C. George Caffentzis, "A Crise de Energia do Trabalho e o Apocalipse" nas Notas da Meia Noite, Petróleo da Meia Noite: Trabalho, Energia, Guerra 1973-1992. Brooklyn: Autonomedia I992 sobre as teorias de Sraffa e o papel do petróleo da reprodução do capitalismo.

53 Veja William Engdahl, Um Século de Guerra: Políticas de Petróleo Anglo-Americanas na Nova Ordem Mundial. Londress: Pluto Press, 2004.

54 Veja Susan Strange, "O Persistente Mito da Perda de Hegemonia”, em Organização Internacional. Vol. 4I, no. 4 (Outono I987) pp. 55I-7, entre outros.

55 Veja a discussão da conexão entre finanças, a direita política e petróleo em Kevin Philipps, Teocracia Americana: os Perigos e Políticas da Religião Radical, Petróleo e Dinheiro Emprestado no Século XXI. New York: Viking 2006.

56 Esse é o erro em Elke Krahmann, "Hegemonia America ou Governança Global? Visões Diferentes de Segurança Internacional” International Studies Review, Vol. 7, No. 4 (Dez. 2005), pp.53I-545. John Kerry etc. sempre deixou claro, a questão não era a hegemonia dos EUA domínio político e militar e liderança internacional (hegemonia) de um lado e dar espaço para um mundo não liderado pelos EUA de outro, no qual os EUA seriam no máximo primis inter pares, mas sim entre os EUA trabalhando proximamente com seus aliados e outras nações 
sido envolvida, como argumentei em outro momento ${ }^{57}$, na tentativa de fundir as elites econômicas e políticas através de inter-relações de poder político e financeiro de maneira global ao redor de um projeto e poder de classe comum, como uma perspectiva de classe global comum. O Estado norte-americano, e especialmente seu poderio militar, nesta versão iriam perder o seu caráter territorial na medida do possível, bem como quaisquer características étnico-culturais remanescentes, mas ao mesmo tempo se tornaria "globalizado", juntamente com a OTAN como principal proteção político-militar para essa classe, com outros Estados seguindo essa mesma linha também. Essencialmente, o caráter autônomo do Estado como dominação de classe direta pelo capital seria acabado, e esse processo, deve-se dizer, tem avançado a um considerável grau, com agências do Estado que são quase removidas da pressão popular, como os bancos centrais, crescendo em termos de poder (na verdade, o que costumava ser "política econômica" está agora sendo em grande parte governado por estes, junto de organizações globais como o FMI, a "troika" da União Europeia, e a OMC). Mas a cessão de poder per se pelos EUA para qualquer outra potência estatal ou para uma comunidade de nações sem um poder hegemônico nunca esteve na agenda, mesmo que alguns elementos do capital possam achar esse cenário aceitável ou atraente.

Condições I) e 3) na análise de Schumpeter, descrita acima, são então concretizadas: há um interesse de classe real e poderoso na hegemonia e em uma forma agressiva e até mesmo militarizada de mantê-la, e há um interesse especificamente capitalista neste projeto, toda uma cobertura ideológica libertária em que livre comércio significa o fim dos conflitos nacionais. Mas faltando a 2), que é um aliado de classe, o projeto hegemônico arrisca colapsar em mera dominação sem hegemonia (liderança), tanto quanto ela não tiver Estados nacionais e setores do capital estrangeiro dispostos a seguir a liderança do poder hegemônico. Os Estados nacionais estão começando a mudar de ideia, como o resto deste artigo deixará claro. E ainda que alguns ainda possam ser confiados em continuar a apoiar os EUA a todo custo, muitos desses o farão não pelo modelo de capitalismo que a hegemonia dos EUA traz consigo, mas por termos estritamente geopolíticos, quais sejam motivos territoriais. Pensa-

através de oraganizações de governança global multilaterais commo a ONU, G20, OMC, FMI e OTAN, ou agindo de maneira sozinha como era geralmente a política durante a administração de GW Bush. Aí é onde a teoria de "Império" de Toni Negri e Michael Hardt exageraram o caso para uma forma de soberania totalmente globalizada e descolada de localização, como os eventos deixaram claro desde a publicação de Toni Negri, Michael Hardt, Império. Cambridge: Harvard I999. Veja a crítica justamente sobre este ponto em Arrighi e Silver.

57 Colatrella, “Em nossas Mãos está Colocado um Poder” op cit., e Steven Colatrella, “Governça Global e Revolução no Século XXI: Greves, Austeridade e Crise Política” em Nova Política, Vol. XIII, No. 3, Verão 20II. 
-se no Japão, algumas outras nações do Sudeste Asiático, como o Vietnã e as Filipinas, e alguns países da Europa Oriental, por exemplo. Mesmo a aliança com a Índia (sobre a qual há mais abaixo) agora é impulsionada mais pelas preocupações com o mapa geopolítico da Ásia do que com entusiasmo pela globalização como na década de 1990 .

John McDermott identificou a classe técnico-profissional de trabalhadores altamente qualificados como um aliado-chave dos capitalistas (qua alta gestão e classe de investidores) contra a maioria da classe trabalhadora na era das corporações. Ele também argumentou de maneira perspicaz que esta classe é uma grande classe constituidora para a globalização.

McDermott escreve sobre essa classe:

Uma massa ou formação social populosa, é constituída por uma porção substancial da força de trabalho moderna, tipicamente $20-30 \% \mathrm{em}$ uma economia desenvolvida, talvez entre 5-15\% em uma menos desenvolvida, embora concentrada nas principais cidades.

É uma classe verdadeiramente internacional. Ativa tanto nas partes mais avançados quanto menos avançadas do mundo, seus membros I) dividem ocupações e postos convergentes dentro do moderno aparato produtivo, governamental e privado, 2) graças à uma convergente, muitas vezes idêntica, educação secundária, universitária e de pós-graduação, ou particular ensino técnico. Membros dessa classe também 3) dividem similares padrões de consumo da vida material/social, 4) cultivam preferências políticas e culturais semelhantes, 5) comumente enviam suas poupanças para os países desenvolvidos, 6) normalmente trabalham para as mesmas instituições, 7) desfrutam de uma sobreposição de frequência e tipos de viagem e turismo e, muitas vezes, 8) têm outras conexões pessoais diretas e institucionais, como através de laços familiares ou educacionais. ${ }^{5}$

Essa classe é essencial para a produção moderna. Em sua forma como gestão intermediária, certamente não poder ser considerada como aliada da classe trabalhadora, mas, como profissionais - especialistas de laboratório, cientistas, médicos, designers de softwares, programadores, designers gráficos, arquitetos, e assim por diante -, existem razões para pensar que podem ter algumas das características atribuídas por Thorstein Veblen aos engenheiros, técnicos e designers de seu próprio tempo. Enquanto McDermott postula que o longo treinamento e qualificação de tal força de trabalho significa que uma lei bi-modal de valor pode agora estar em operação e pode justificar es-

58 John McDermott, “Uma Massa Constituidora para a Globalização”. Repensando Marxismo Volume 20, Número I, 2008 pp. I5I-I59, p. I52. 
truturalmente maior remuneração para profissionais altamente qualificados (quem me dera!), isso por si só não essencialmente significa que uma aliança com o capital em sua forma atualmente hegemônica é necessariamente uma realidade permanente. $\mathrm{Na}$ verdade, há sinais de que essa aliança se desfez nos últimos anos, na esteira do colapso econômico de 2008 e a subsequente recessão e unilateral recuperação, em que os ganhos estão indo para uma pequena minoria59. Ainda que uma classe global provavelmente vá querer uma economia global, a lacuna entre promessas e realidades sugere que pode haver mais de uma globalização possível sob as atuais capacidades materiais, e se a atual versão não está beneficiando a classe mais global, uma necessária à avançada economia contemporânea, então outras possibilidades se abrem. Uma globalização não capitalista é possível? É possível que a classe média técnica-profissional leve a cabo suas criativas, intelectualmente desafiadoras e intrinsecamente interessantes formas de trabalho sem depender de instituições estritamente capitalistas (M-C-M') para as quais nenhum projeto, independentemente de quão gratificante, racional, benéfico, materialmente possível ou justificável, deve ser realizado a menos que gere lucros para elas? É possível um diferente bloco histórico gramsciano?

\section{Pivô Eurasiano}

Em um sentido muito real, a última obra de Arrighi, Adam Smith em Pequim, é uma sequência e uma conclusão para $O$ Longo Século XX, e um capítulo final para o que eu vejo como uma trilogia, incluindo Caos e Governança no Sistema Mundial, coeditado com Berverly Silver. Adam Smith em Pequim postulou a possibilidade da China liderando um diferente modelo de desenvolvimento, baseado na restauração da soberania nacional sobre a escolha do modelo econômico e social mais bem adaptado para cada país da maneira como seu governo e seu povo entender melhor. Mas isso estava ligado com um mercado mundial, incluindo todos os países, e trazendo aquela paridade crescente que Adam Smith viu o mercado mundial eventualmente trazendo

59 Robert Reich, "A Escolha do Século" New York Times, Nov. I2, 2014 reporta que todos os IO०\% (!) dos ganhos da recuperação foram para os I0\% das pessoas que mais ganham nos EUA e $95 \%$ para o I\%. Isso deixaria os $9 \%$ atrás do I\% no topo recebendo apenas $5 \%$ dos ganhos, significando um ganho desproporcionalmente baixo se comparado com sua presença npúmero, sem contar a posição crucial que jogam, como McDermott argumenta, na economia. E se tal classe no rico EUA pudesse ser, ao invés, 20-30\% da população, a base material da aliança pareceria bastante escassa. Veja também Paul Krugman, "Graduados contra Oligarcas", NY Times Nov.I, 20II, que demonstra que nos últimos 30 anos os graduandos universitários não tem se beneficiado desproporcionalmente do crescimento, com quase TODOS os benefícios do aumento de renda nacional nos EUA indo para o o topo ०,००I\%. 
se liberto da hegemonia ocidental. O Ocidente impôs seu maior poder militar e tecnológico em Estados não ocidentais. Caos e Governança terminou com um ensaio conjunto por Silver e Arrighi vendo uma bifurcação na estrada a frente: ou uma aceitação benigna por parte da atual hegemonia dos EUA de que seu dia ao sol estava acabando e que ele poderia continuar uma grande potência entre outras em uma nova ordem mundial baseada em maior cooperação, ou usar sua superioridade militar sem precedentes para impor sua vontade sobre o próprio sistema capitalista, reduzindo outros centros de lucro à Estados tributários e se tornando o centro de um império mundial. Neste caso, e a ironia não é perdida por Arrighi, seria o país capitalista por excelência, os EUA, que constituiriam a maior ameaça à existência continuada do capitalismo. Seu poder pode ser suficiente para finalmente encerrar mais de 500 anos de uma série de ciclos históricos de acumulação e de transferência de hegemonia de uma potência para a outra, que tem sido a pré-condição para essa reprodução em uma maior escala. Assim, à primeira vista, pode parecer que temos uma chance - se nos é permitido escolher - entre uma ordem de mercado mundial benigna liderada pela China entre iguais ou um império mundial com os EUA no seu centro.

Mas as coisas são mais complicadas do que o cenário indica. De fato, como Arrighi deixa claro, o máximo que podemos dizer com alguma certeza é que direção exatamente a China tomará é impossível de se prever, e que as chances de uma economia de mercado em que a China lidere como uma síntese de modelos ocidentais e asiáticos de desenvolvimento econômico (a "Revolução Industrial" e a "Revolução Industriosa") têm aumentado ao longo dos últimos anos. Da mesma forma, as chances de conflito entre grandes potências e caos sistêmico têm aumentado. Ainda assim, algumas coisas são claras: os líderes chineses não tem intenção de continuar dependentes da dominação ocidental e dos EUA sobre a oferta de moeda mundial nem do monopólio de poder dos EUA sobre petróleo e gás natural; China e Rússia não cederam sua segurança geopolítica nacional nem para as instituições de Governança Global, nem para os EUA e a OTAN, que, pelo contrário, eles veem, muito justamente, como as maiores ameaças a sua segurança, nem para uma globalização etérea nas quais esferas de influência, geopolítica e guerra são coisas do passado; e ambas estão, na melhor das hipóteses, impacientes, e na pior, tornaram-se suspeitas das contínuas aventuras militares dos EUA.

A criação por parte da China da Rota da Seda, do Banco de Investimento Asiático, seu patrocínio da Organização de Cooperação de Xangai (OCX), sua abertura conjunta com a Rússia de uma nova janela de ouro, e sua série de acordos bilaterais com a Rússia e outros membros da OCX, com o Qatar, Canadá e mesmo Inglaterra, permitindo o comércio direito na moeda 
de cada um (ao invés de dólares), e sua construção de um canal transoceânico na Nicarágua ${ }^{60}$, tudo deixa claro que qualquer dependência de finanças politicamente ligadas aos EUA está fora de questão para a China. A Rússia pretende evitar a dependência destas mesmas fontes tanto quanto possível, e por essas razões tem se aproximado economicamente e diplomaticamente de Pequim $^{61}$. Esse fato por si só coloca estas duas grandes potências em posições de alvo para os EUA. A criação por parte da China de fontes alternativas de financiamento em relação àquelas apoiadas pela hegemonia dos EUA como o FMI e o Banco Mundial - proporcionando investimentos na África, infraestrutura na Eurásia e comprando petróleo russo, e através de convites ao Irã para aderir à OCX (assim como para Índia e Paquistão $0^{62}$ e acordos bilaterais com o Qatar para comprar petróleo desses países e alguns na África cada vez mais sem o uso de dólares - todas essas atividades significam conflito com os EUA a menos que este esteja disposto a ceder seu controle privilegiado do capital mundial graciosamente. O que agora parece improvável.

Enquanto isso, a justificável revolta da Rússia com a expansão da OTAN para perto de suas fronteiras e os convites propostos à Geórgia e à Ucrânia para aderirem à OTAN, e a UE como uma casa no caminho para a OTAN, significa que a geopolítica está de volta ao mapa. A expansão da OTAN, entretanto, devemos relembrar, ocorreu principalmente durante a administração de Bill Clinton, ou seja, durante o ponto mais alto da globalização "pacífica" e o aparente movimento irresistível em direção à Governança Global. Por esta única razão, qualquer tentativa de prevenir o risco de uma guerra mundial, de potenciais blocos hegemônicos competidores, através do apelo à anterior fase multilateral de formulação de políticas, organizações internacionais e expansão do comércio mundial, está fadada ao fracasso: assim como a Primeira Guerra Mundial, a Grande Depressão, o Fascismo, o Stalinismo, o New Deal e a Segunda Guerra Mundial seguida da Guerra Fria, todos tiveram raízes na tentativa de criar um mercado autorregulado como modelo para a sociedade no fim do século XIX e início do século XX, como Polayni demonstra, a "Nova Guerra Fria” também é um aspecto da ampla realidade que Polanyi notou como um "duplo movimento", em direção e contra a subordinação de mais da vida e das instituições da sociedade ao controle do mercado autorregulado e

60 "O Canal da Nicarágua da China Pode Desencedear uma Nova Revolução Centro-Americana" The Daily Beast, 30 de novembro de 20I4. http://www.thedailybeast.com/articles/20I4/II/30/ china-s-nicaragua-canal-could-spark-a-new-central-america-revolution.html.

6I James Petras, “A Vulnerabildiade da Rússia às sanções da UE-EUA e Intrusões Militares" Global Research, 9 de novembro de 20I4, argumenta que é precisamente a classe capitalista conectada com o Estado que é o elo fraco na tentativa de Putin de continuar independente nesta crise.

62 Que aderiram em 20I5. 
do capital móvel, hoje sob a forma do uso da dívida para impor a privatização sobre toda a sociedade.

A expansão da OTAN tem ocorrido por três questões relacionadas: manter indefinidamente a hegemonia dos EUA e prevenir o surgimento de quaisquer desafiantes à essa ordem, incluindo as principais potências regionais; dominar as principais fontes e rotas de petróleo e gás natural; e impor regras neoliberais e o uso da dívida para privatizar e integrar na ordem globalizada das corporações, finanças globais e hegemonia dos EUA qualquer país ou setor que já não tenha sido totalmente integrado. Se a política dos EUA e de Wall Street tem, em certa medida, se auto-iludido sobre o quanto a China estava disposta a colocar sua sociedade e sua economia sob essas relações poder, suspeitas quanto à Rússia estavam profundamente enraizadas. Enquanto a história do aparente desafio da URSS à dominação dos EUA é uma, acredito que há uma história de longa duração da Rússia em jogo aqui também. A Rússia nunca foi totalmente integrada no sistema capitalista mundial como um país periférico, mesmo que alguns setores de sua economia tenham se aproximado dessa relação ${ }^{63}$. De fato, "Rússia Permanece fora do Terceiro Mundo" é o título do capítulo de Stavriano sobre Rússia durante a ascensão do capitalismo como sistema mundial. O poder do Estado russo e a manutenção de relações não-privatizadas de propriedade sobre a terra, entre outros fatores, manteve a Rússia independente da plena integração como uma mera fonte de matérias-primas ou força de trabalho por séculos. A Revolução de I9I7 e o subsequente regime soviético reforçaram essa relativa distância de dominação das relações capitalistas. Certamente até mesmo a URSS precisava de algum acesso ao capital móvel, e seu limitado acesso a essa fonte de poder e recursos significou ficar para trás do Ocidente no fim dos anos I970 e os anos I980 durante o movimento em direção à tecnologia de ponta. E o programa de Terapia de Choque ${ }^{64}$ do começo dos anos 1990 , no qual meros sete oligarcas ganharam enorme controle sobre grande parte da economia russa, e durante o qual a base industrial de uma superpotência foi desmantelada,

63 Isso é tornado claro por L. R. Stavrianos em seu magistral Fissura Global: o Terceiro Mundo Amadurece Nova York: William Morris I98I, pp. 68-74; obviamente aqui nós entramos no terreno clássico dos debates marxistas: VI Lenin, O Desenvolvimento do Capitalismo na Rússia, VI Lenin Trabaçhos Coletados Volume 3 Moscou: Progress Publishers, I977 obviamente argumentou o oposto, no contexto do debate marxista russo com Narodniks. Isso significa que o debate sobre a integração russa no sistema mundial capitalista está intrinsecamente interligado com o debate sobre as terras comuns russas. Esse é uma questão de importância global hoje em dia mas está além do escopo deste trabalho.

64 Veja entre outros Naomi Klein, A Doutrina de Choque, e Marshall I. Goldman, A Piratização da Rússia: a Reforma Russa Vai Embora Londres e Nova York: Routledge, 2003, bem ocmo Michel Chossudovsky, A Globallização da Pobreza e a Nova Ordem Mundial $2^{\text {a }}$ edição Pincourt Quebec: Global Research 2003. 
a deixou como uma fonte de commodities de energia e armas no mercado mundial. Isso foi o mais próximo em sua história de 500 anos de capitalismo que a Rússia chegou em direção à plena integração e dependência das forças capitalistas. ${ }^{65}$

Além disso, os EUA continuaram a reconhecer a Rússia, mesmo depois da Guerra Fria ter terminado, como seu único potencial competidor militar, principalmente devido à manutenção da Rússia de seu grande arsenal de armas nucleares, e de um ainda maior, ainda que um pouco enferrujado, poder militar convencional dentro do alcance das fronteiras dos membros da OTAN, um fato ironicamente tornado mais relevante justamente devido à expansão da OTAN para ainda mais perto das fronteiras da Rússia. O fato da Rússia ter avançado contra os oligarcas sob Putin, ter continuado o capitalismo mas com as mais poderosas empresas próximas ao Estado russo e seus líderes, e ter uma vasta oferta de petróleo e gás natural fora do controle dos EUA, significa que ela continua sendo uma ameaça em potencial. Essa combinação de poder militar e de se posicionar como uma importante fonte de petróleo e gás para a Europa e Ásia e, portanto, como uma força que poderia quebrar qualquer estrangulamento dos EUA sobre outras economias do mundo, significa que os EUA têm continuado, com apenas uma breve pausa, suas tentativas em relação à capacidade de primeiro ataque nuclear através do desenvolvimento e implantação de um escudo antimísseis. A saída, sob a segunda administração Bush, do tratado START, a implantação na Polônia e na República Checa de partes do sistema, e a provocação de um golpe patrocinado na Ucrânia no ano passado, seguido por uma série de movimentos agressivos, incluindo sanções, um efeito propaganda em todo o mundo através de declarações oficiais e meios de comunicação relacionados aos EUA tratando a Rússia e seu presidente como agressores, hostilidade contra o governo da Síria, têm demonstrado claramente para a Rússia que espera-se que ela se afaste de qualquer pretensão à segurança nacional e interesses geopolíticos, à soberania sobre seus próprios recursos naturais e para quem ela pode vender estes, e à qualquer participação em qualquer modelo alternativo de desenvolvimento diferente da globalização neoliberal sob o domínio das finanças ligado aos EUA e seus aliados.

Em vez disso, a Rússia tem, ao longo da última década, se movido

${ }_{6}$ Aqui minha análise desafia as por vezes brilhante formulações e árdua pesquisa do próprio Lênin em O Desenvolvimento do Capitalismo na Rússia. Mas enquanto Lênin descreveu com precisão a tendência, eu acho que para o bem de sua polêmica que teve consequências políticas imediatas (o debate com os Narodniks sobre a classe trabalhadora versus a revolução camponesa), ele exagerou o caso, particularmente por subestimar o grau em que a terra foi privatizada na Rússia pré-Revolução. 
para cada vez mais perto da Alemanha, como um velho sonho de Lênin, da tecnologia alemã ligada aos recursos russos, começado a tomar forma. Mas os laços ocidentais estão agora em perigo em relação a questões diplomáticas, demonstrando o que James Petras chama de uma fraqueza estratégica da estratégia de Putin para restaurar a soberania da Rússia e sua economia depois do colapso da economia e da sociedade durante os anos Yeltsin. ${ }^{66}$ Com a alta demanda da China por petróleo devido ao seu próprio crescimento econômico, e graças à conveniência geográfica, a Rússia tem recentemente se movido para próximo da China. Juntas, as duas potências começaram - não sem dificuldades e contradições, reconhecidamente - a construir uma alternativa ao dólar, às finanças ocidentais e mesmo à própria globalização. Essa alternativa, baseada na soberania nacional sobre os modelos de desenvolvimento, comércio sem a dominância do dólar (através da aceitação das moedas de cada um ou de ouro, ou comércio do tipo petróleo por produtos), frouxa aliança militar, e na estreita integração infraestrutural de praticamente toda a Eurásia, está agora em aberto, se ainda não em pleno andamento.

A China está financiando e planeja unir através de infraestrutura, como com ferrovias de alta velocidade, toda a Eurásia, desde sua própria Costa Pacífica através de portos que tem construído no Paquistão e também pela Ásia Central em direção à Turquia, Veneza e Berlim ${ }^{67}$ e pelo Mediterrâneo, Europa e Oriente Médio. Uma aliança econômica alemã-russa ${ }^{68}$, tornada mais difícil através do golpe da OTAN-EUA-UE na Ucrânia, mas ainda não inteiramente fora da mesa (com os formuladores de política alemães parecendo agora consideravelmente divididos), ligaria a UE, ou uma parte substancial dela a este projeto. A União Econômica Eurasiática foi criada em maio de 2014 e as ambições em relação a ela, ou alguma sucessora, são vastas. Essa união seria imune à dominação estadunidense dos mares - teria acesso a todos os recursos naturais e mão de obra e à infraestrutura de transporte através da terra através de ferrovias de alta velocidade financiadas e construídas pela China por toda a Ásia e Europa, além do acesso ao Oceano Índico, o Mar da China e o Golfo Pérsico. Somado à notável presença da China na África - mais de um milhão de chineses vivem agora nesse continente e o investimento e a infraestrutura chineses têm integrado cada vez mais partes da África ao de-

66 James Petras, “A Vulnerabildiade da Rússia às sanções da UE-EUA e Intrusões Militares" Global Research, 9 de novembro de 2014 .

67 Pepe Escobar, "Ainda mais Além na Estrada Multipolar: A Rota da Seda da China para a Glória” Counterpunch, Nov. I4-16 2014.

68 O realista George Friedman em Os Próximos Cem Anos Nova York: Anchor 20ı argumenta que uma aliança russo-alemã, não uma hegemonia chinesa é a real história do século XXI. 
senvolvimento econômico liderado pela China ${ }^{69}$ - esses processos podem levar precisamente ao fenômeno no centro da agenda de pesquisa de Arrighi: a ascensão de uma potência hegemônica sucessora, capaz de reorganizar as bases para acumulação de capital mundial para o sistema como um todo, e, em uma escala geográfica maior, combinando domínio político e econômico com uma liderança percebida como do interesse de todas ou da maioria das elites e uma expansão da distribuição de benefícios do sistema para uma grande parte da população mundial. Para Arrighi, uma maneira de expressar essa possibilidade é a realização da esperança de Adam Smith de que a economia de mercado iria distribuir avanços tecnológicos, econômicos e político-militares para todos os países, criando uma condição mais ou menos igual entre as nações do mundo de tal forma que elas encontrariam no comércio pacífico e no desenvolvimento um interesse mútuo. No momento, parece que o cenário preocupante de Silver e Arrighi identificado no seu ensaio final em Caos e Governança no Sistema Mundial é, ao invés, um resultado mais provável. Esse cenário é o colapso do sistema para o caos devido ao poder hegemônico em declínio resistir às mudanças, neste caso os EUA usando seu poder militar, sem precedentes na sua capacidade destrutiva ou no seu alcance global, para evitar que um novo sistema como tal surja. ${ }^{70}$

Como afirmam os autores, "o ajuste e acomodação dos EUA à potência econômica ascendente da região do Leste Asiático é uma condição essencial para uma transição não catastrófica para uma nova ordem mundial". Eles acrescentam que, como no passado, uma nova ordem, assim como Marx argumentou no que diz respeito a cada nova classe dirigente, deve dominar através de uma base de classe social mais ampla que a classe dirigente anterior (a hegemonia holandesa representou as burguesias nacionais, o domínio britânico incluiu as elites coloniais e mais tarde as elites orientadas em toda parte para o livre comércio, e a hegemonia inicial dos EUA envolveu um semi-New Deal de descolonização e as garantias de um Estado de bem-estar social para os trabalhadores nos países industrializados):

Uma condição igualmente essencial é a emergência de uma nova liderança global a partir dos principais centros de expansão econômica do Leste Asiático. Essa liderança deve estar disposta e ser capaz de levantar-se perante à tarefa de fornecer soluções ao nível sistêmico para os problemas de nível sistêmico deixados pela hegemonia dos EUA. O mais severo desses problemas é o aparentemente intransponível abismo entre as chances de vida de

69 Veha Howard W. French, O Segundo Continente da China Nova York: Knopf 2014. 70 Giovanni Arrighi, Beverly Silver, “Conclusão" em Arrighi \& Silver eds., Caos e Governança no Sistema Mundial, pp. 288-9. 
uma minoria da população mundial (entre io e $20 \%$ ) e da vasta maioria... Esta é uma imponente tarefa que os grupos dominantes dos Estados do Leste Asiático mal começaram a empreender. Nas transições hegemônicas passadas, grupos dominantes tiveram êxito na tarefa de formar uma nova ordem mundial apenas depois de grandes guerras, caos a nível sistêmico e intensa pressão de movimentos de protesto. Essa pressão de baixo tem se alargado e se aprofundado de transição para transição, levando a blocos sociais ampliados a cada nova hegemonia. Assim, podemos esperar que contradições sociais desempenhem um papel muito mais decisivo do que nunca na formação tanto da transição quanto de qualquer ordem que eventualmente emerge do caos sistêmico iminente. Mas se os movimentos vão, em grande medida, seguir e ser moldados pela escalada de violência (como em transições passadas) ou preceder e efetivamente trabalhar para conter o caos sistêmico é a questão em aberto. A sua resposta está, em última análise, nas mãos desses movimentos. ${ }^{71}$

Os movimentos de 20II, com seus protestos dos $99 \%$ contra o I\%, parecem ter generalizado alguns dos temas de vanguardas dos movimentos de massa antiglobalização antecedentes, do fim dos anos I990. Com suas demandas por democracia direta e um fim do uso da dívida para explorar o trabalho e expropriar terras, recursos e bens públicos, esses movimentos podem ter fornecido uma agenda para pressão popular futura naqueles que se apresentariam como os líderes de uma ordem mundial pós-hegemonia dos EUA. Mas a atual liderança de Rússia e China (e do Irã, Síria e outros países aliados), ou, nesse caso, da própria UE, ainda que esteja dividida entre atlantistas pró-globalização dos EUA e entre integração eurasiática, dificilmente são atentas ou interessadas em atender a essas demandas.

As classes que têm um interesse em tal alternativa eurasiática incluem a indústria e finanças chinesas, petróleo e gás russos, e industriais em toda a Europa que não se beneficiaram com o domínio das finanças globais e de um Euro sobrevalorizado (que, no entanto, desvaloriza as exportações alemãs em comparação com o marco alemão). Eles constituem um bloco indiscutivelmente mais amplo em suas conexões sociais do que as finanças globais, mas são dificilmente democráticos em sua natureza. Para ter certeza, o absurdo de uma economia mundial em que as três maiores economias: os EUA, a União Europeia e a República Popular da China estão todas orientadas para a exportação global a despeito de suas vastas populações, forças de trabalho qualificadas ou cada vez mais qualificadas e consideráveis recursos em escala continental, ao invés de em direção a um projeto de desenvolvi-

7I Arrighi e Silver, “Conclusão” em Caos e Governança no Sistema Mundial, p. 289. 
mento essencialmente nacional ou regional baseado em uma versão moderna de uma "revolução industriosa" é inexplicável, exceto por ser do interesse de uma classe ou aliança de classes mais poderosa do que a alternativa. Assim, o apelo potencialmente ainda maior de um projeto de desenvolvimento em escala continental é aparente. Mas, as formas repressivas de Estado de ambas as grandes potências - essas falam por si e dão uma pausa por um momento para qualquer visão ingênua de tal alternativa, dadas as formas brutais que o controle social tem em ambos os países (não que seja muito brando nos EUA ou Europa nos últimos anos também) - deixam de lado o fato de que os combustíveis fósseis, por exemplo, ou que as relações com os países da Ásia Central e da África têm pelo menos um toque de estilo do velho colonialismo, significa que a indústria chinesa e o petróleo russo podem não fornecer um modelo de bloco histórico muito mais representativo que a América das corporações globalizadas e das finanças internacionais.

Terminarei esse artigo com algumas reflexões, ao invés, sobre a classe média de John McDermott de profissionais, técnicos, gerentes de nível médio, e cientistas, sobre a classe trabalhadora, e sobre potenciais aliados e projetos comuns. Mas, primeiro, um último pensamento está em ordem sobre a própria teoria de Arrighi de potências hegemônicas sucessoras.

Arrighi ressalta que cada nova hegemonia, enquanto se movimentando em direção a organizar o sistema mundial em uma escala maior, com uma base social mais ampla, também se move para trás historicamente, retornando aos elementos que caracterizaram a potência hegemônica que precedeu aquela que ela própria substituiu. Assim, os holandeses fundiram os interesses capitalistas com a integração estatal territorial em eco com Veneza, os britânicos organizaram as finanças internacionalmente em uma base capitalista similar à Gênova, mas também expandiram a aliança Estado territorial-finanças globais, os EUA basearam sua hegemonia em grandes corporações similares à Companhia das Índias Orientais holandesa, e no apoio à independência nacional e assim adiante. Arrighi sugere que o capitalismo do Leste Asiático relembra a escala pequena à média das firmas de base familiar numa economia de mercado, que caracterizou a economia britânica durante quase todo o seu período hegemônico. Eu sugeriria que, embora este movimento para atrás do Leste Asiático para retomar o capitalismo britânico seja real, há uma periodização alternativa possível. Acredito que, em um sentido, houve duas versões diferentes da hegemonia dos EUA e não apenas uma. De I945 a I979, os EUA basearam seu domínio em corporações industriais usando integração vertical para internalizar mercados, um New Deal internamente e um keynesianismo militar internacional e distância, se não hostilidade, para com o poder potencial das finanças globais. Como o próprio Arrighi escreve, 
quando, depois de I979, os EUA se aliam com as finanças, as implicações foram vastas:

A negligência estadunidense dos princípios do dinheiro desde Roosevelt e Truman tinha uma finalidade social - em primeiro lugar o New Deal doméstico e depois o internacional. Trabalhar lado a lado com as altas finanças privadas significava abandonar tudo o que o governo dos EUA tinha defendido, durante quase meio século, não apenas em questões monetárias, mas em questões sociais também..$^{72}$

Em certo sentido, não foi a hegemonia sucessora, mas a dos próprios EUA que retomou as políticas e formas britânicas. Os apelos à liberdade de comércio, o mantra dos livres mercados e da filosofia libertária-individualista que tem sido dominante agora por décadas, bem como a volta de uma economia global ao invés de uma baseada dentro dos recipientes nacionais de poder, são todos retornos a formas britânicas pelos próprios EUA. Isso, de certa maneira, deixou o caminho aberto a China e seus aliados em qualquer projeto hegemônico alternativo para retornar não a formas britânicas a partir das americanas, mas as próprias americanas anteriores - o Estado nacional em vez das finanças globais no controle da criação do dinheiro, na preocupação com emprego (embora muito seja deixado a desejar de qualquer versão Chinesa do New Deal até agora, deve ser dito), políticas de bem-estar social como o "campo socialista harmonioso" e as recentes alterações relativamente pró-trabalhador em leis trabalhistas - e embora as firmas familiares sem dúvidas permanecem importantes - a ascensão de corporações globais baseadas na China. No entanto, para além deste retorno às formas hegemônicas norte-americanas I.o, o projeto de unir uma vasta parte das regiões do mundo em uma economia de mercado conectada, com alguma infraestrutura facilitando o transporte e as comunicações, também remonta para ainda mais atrás para a economia mundial antes da própria ascensão do capitalismo - aquela originalmente ligada de maneira política pelo Império Mongol. ${ }^{73}$ Isso é interessante porque sugere que a visão Smithiana de Arrighi, que uma economia de mercado mundial de Estados mais ou menos iguais, sem uma hegemonia baseada em uma potência predominante aliada com a classe capitalista dominante, pode ser possível em bases geográficas semelhantes à última economia mundial não capitalista.

72 Arrighi, O Longo Século XX, p. 3I9.

73 Janet Abu-Lughod, Antes da Hegemonia Europeia: a Economia Mundial 1250-1350. Oxford e Nova York: Oxford Univ. Press, I989. 


\section{A base de classe da sociedade pós-capitalista, ou, a república}

Então, temos uma classe global de finanças que agressivamente necessita se assentar em todos os lugares, se fixar em todos os lugares, contando com a dívida para expropriar (privatizar) e explorar todo recurso e atividade, ligada ao poderoso Estado hegemônico com uma rede global de bases militares que procura controle total sobre o petróleo e sua disponibilidade, e impondo sua própria moeda a todo custo como única moeda mundial; uma crescente aliança de Estados, incluindo os governos populistas de esquerda radical na América Latina, a própria China, Rússia, grandes partes da África e muitos outros em variados estágios de frustração com ou em oposição ao regime hegemônico, mas com grandes verbas disponíveis, especialmente por parte da China, e com consideráveis recursos energéticos; alianças geopolíticas vagas, mas cada vez mais definidas, de um lado ou outro da equação, com alguns Estados chaves (Índia, por exemplo, talvez Alemanha) jogando agora de um lado e depois de outro em um padrão confuso. Sabemos que nenhum projeto estatal, nacional ou internacional, tem muita probabilidade de sucesso sem o apoio de uma poderosa classe ou coalizão de classes na sociedade em pelo menos uns Estados chaves. E nenhuma classe, não importando sua relevância (como os industrialistas domésticos da Grã-Bretanha, por exemplo, no final do século XIX e XX, ou os proprietários de plantações nos EUA pós-Guerra Civil), é provável que veja seus próprios objetivos cumpridos sem o apoio de poder estatal, logo, sem suas necessidades coincidirem com aquelas dos Estados ou do interesse nacional. Existe uma configuração de interesses de classe com interesses estatais capaz de quebrar o monopólio de poder das finanças e das corporações globais e do complexo militar-corporativo dos EUA, enquanto ou democratizando ou permanecendo independente dos aspectos mais repressivos do projeto infraestrutural eurasiático liderado por China e Rússia? Em outras palavras, há uma anti-causa à Terceira Guerra Mundial que tenha recentemente aparecido no horizonte?

Esse artigo não pode definitivamente responder a essa pergunta, é claro, mas tem por objetivo delinear as fontes onde tal resposta pode ser encontrada. Este autor já tem argumentado que a luta contra a dívida e austeridade tem sido liderada por uma classe trabalhadora cada vez mais global em experiência, e tem sido especialmente evidente em setores específicos. Esses incluem transporte e logística, instituições públicas e serviços, como uma linha de frente na defesa dos Estados de bem-estar social existentes e remanescentes e contra a privatização do setor público tout court, e setores de exportação de países chaves do Sul Global (têxteis e sapatos no Vietnã, juta e vestuário em 
Bangladesh, e eletrônicos na China, para citar alguns). ${ }^{74}$ Também argumentei que imigrantes, engajando-se em ação coletiva em reação ao uso da dívida e programas de ajuste estrutural pelas instituições da Governança Global (o FMI e o Banco Mundial), apresentam a possibilidade de uma globalização da classe trabalhadora como ator político e que esta possibilidade tem sido realizada em algumas épocas e lugares. ${ }^{75}$ Mas um elemento adicional, a saber, o que é hoje muitas vezes chamado de "classe criativa" ou "trabalhadores do conhecimento" - a classe média técnica de John McDermott, parece para mim a chave para qualquer possibilidade de transcender tanto a atual e perigosa conjuntura quanto para desenvolver um sistema mundial alternativo ao capitalista, que tem sido dominante pelos últimos cinco séculos. Tal alternativa não seria baseada no que Veblen chamou de "propriedade ausente" ${ }^{6}$, ou seja, no controle puramente monetário e orientado ao lucro, e direitos à tomada de decisão em relação ao uso da riqueza e capacidade de criar e distribuir bens e serviços úteis. Pelo contrário, iria contar com a capacidade de usar o conhecimento acumulado da sociedade humana, personificado, como Veblen viu, em cientistas e em técnicos e engenheiros, e, como McDermott argumenta, em uma classe real de pessoas - as camadas médias ou classe média de profissionais e técnicos. Uma aliança em que esta classe e sua lógica sejam importantes elementos poderia muito bem se provar compatível, similar à visão de Arrighi e Adam Smith. Mercados para produtos disciplinando empresas que não são dominantes sobre estes, e ao ponto em que fazer dinheiro é para comprar coisas úteis para si, para o agregado familiar ou para uma comunidade ou para usar em uma maior produção de coisas úteis, e a visão marxista da produção para uso e não para lucro, e a visão marxista-feminista do trabalho necessário para reprodução social e não trabalho excedente para exploração, e a ênfase na proteção e expansão dos bens comuns - todas essas visões e outras de uma vida melhor podem se provar compatíveis, se reforçando mutuamente, expressando diferentes elementos de um bloco histórico, uma aliança popular transcendendo o capitalismo e para além da hegemonia.

Para Veblen, a propriedade ausente, essencialmente o uso de finanças e crédito para controlar as atividades de negócios visando o lucro e não a produção, é baseada em uma lógica feudal, estranha para a ciência moderna. 77 "Como a indústria, como um processo de fabricação e de produção dos

74 Colatrella, "Em Nossas Mãos” op. cit, and Colatrella, "Governança Global e Revolução” op. cit

75 Em Steven Colatrella, Trabalhadores do Mundo: Migrantes Africanos e Asiáticos na Itália nos anos 1990 Trenton e Asmarra: Africa World Press 200I.

76 Thorstein Veblen, Propriedade Ausente Nova York: Viking Press I923

77 Veblen, Propriedade Ausente p. $5^{\mathrm{I}}$ 
meios de vida, o trabalho à disposição não tem nenhum significado para os proprietários ausentes que se situam sobre o contexto fiscal desses interesses velados" ${ }^{78}$ Em contraste, "O sistema tecnológico é uma organização de inteligência, uma estrutura de ativos intangíveis e imponderáveis, na natureza dos hábitos de pensamento" e como McDermott argumenta, essa lógica existe, como toda lógica o faz, na forma de classes existentes no mundo real, "Ela reside nos hábitos de pensamento da comunidade e torna-se realidade nos hábitos de pensamento dos técnicos". ${ }^{79}$ Hoje, questões como energias renováveis e o próprio destino de nossa espécie na terra em face das mudanças climáticas envolvem assuntos de agricultura sustentável, de energia renovável, do aproveitamento da energia do sol, do vento, da água, do hidrogênio, e da fusão nuclear a frio; das mais recentes descobertas na ciência e as possibilidades de utilizá-las para fins humanos, tais como a capacidade de transformar luz em matéria ${ }^{80}$, materiais básicos, como enzimas, em alimentos nutritivos ${ }^{81}$, softwares de computador em produção através de impressão 3-D, e exploração do espaço consistente com a relatividade ${ }^{82}$, enquanto se viaja em rodovias produtores de energia solar ${ }^{83}$, para citar algumas. No entanto, esta não é apenas uma questão da descoberta de forças naturais existentes, é precisamente o que Marx se referiu como o desenvolvimento das forças produtivas, estas forças sendo, primeiro e sobretudo hoje em dia, as capacidades coletivas de conhecimento moderno aproveitadas para transformar o mundo. Veblen entendeu isso muito bem:

No século XX, os técnicos tornaram-se um dos fatores padrão da produção; tanto quanto os recursos naturais de um país como madeira, carvão, petróleo e minérios. De fato, estas coisas são recursos naturais ao invés de características da paisagem porque os técnicos sabem como transformá-los ao uso. E a extensão e a variedade dos recursos naturais do país estão aumentando constantemente, porque e nessa intensidade os técnicos estão continuamente aprendendo a fazer uso de um maior número e de maior

78 Ibid. p.216.

79 Ibid p.28o.

80 "Cientistas descobrem como transformar luz em matérias depois de missão de 80 anos" por Gail Wilson I9 de Maio de 20I4 Imperial College London http://www3.imperial.ac.uk/ newsandeventspggrp/imperialcollege/newssummary/news_I6-5-20I4-I5-32-44

8I "A Impressora de Frutas 3D e a Framboesa com Gosto de Morango" Michael Molitch-Hou 27 de Maio de 2014 http://3dprintingindustry.com/20I4/05/27/3d-fruit-printer-raspberry-tasted-like-strawberry/

82 "Nós poderiamos Viajar para Novos Mundos com a Nave Enterprise da NASA" The Verge I3 de Junho de 20I4;

83 www.youtube.com/watch?v=qlTA3rnpgzU 
variedade dessas coisas. A questão dos recursos naturais é, afinal, uma questão de percepção técnica. ${ }^{84}$

O mesmo ponto pode ser feito hoje sobre qualquer coisa, desde códigos genéticos a energia solar, sobre se e quão rápido os vastos hemisférios Eurasiano, Africano e Americano podem ser transponíveis para o nosso lugar no universo e a conexão dos humanos a própria vida. ${ }^{85} \mathrm{Em}$ suma, a riqueza atual existe tanto na pessoa e nas capacidades da população trabalhadora como nas matérias-primas, dinheiro e capital ou nas plantas industriais e infraestrutura tecnológica ou nos códigos e programas de computador. Na verdade, todos estes últimos dependem da capacidade de trabalhadores com conhecimento para sua invenção, existência, manutenção, extensão, desenvolvimento, utilidade e, fundamentalmente, sua rentabilidade ou sua utilidade para aqueles no poder durante a guerra ou paz.

O regime de capital financeiro, recentemente apelidado de "Creditocracia” por Andrew Ross ${ }^{86}$ e apoiado pelo poderio militar americano, ao usar e incorporar em uma rede de dívida qualquer atividade social de todos os tipos, é claramente um maior desenvolvimento do regime de propriedade ausente que Veblen criticara quase há cem anos atrás. O alternativo projeto hegemônico infraestrutural eurasiano, liderado pela China e incluindo Rússia, claramente requer a mais massiva presença e a centralidade do conhecimento dos trabalhadores de todos os tipos - cientistas, engenheiros, técnicos e assim por diante, bem como trabalhadores qualificados no sentido mais tradicional. Portanto, se alguém alienar essa crucial classe que John McDermott tem visto como uma massa constituidora para a globalização e outros requererem suas habilidades em larga escala, essa classe estará em uma posição de fazer demandas e também de se afirmar como uma potencial líder da sociedade, em aliança com outras classes que poderiam se beneficiar de suas habilidades, visão e programa. Assim como Adam Smith viu a sociedade de mercado como uma forma não-capitalista de produzir não lucro e dinheiro mas bens úteis de um modo benéfico, Karl Marx viu a cooperação e o processo de produção como coincidentes com, mas distintos, do processo de valorização da auto expansão do capital, e Veblen viu a indústria como separada dos negócios em sua natureza e seguindo diferentes e crescentemente opostas lógicas, McDermott pode ter encontrado uma distinção entre a globalização em si - uma

84 Ibid. p.272.

85 Como o primeiro episódio do programa "Cosmos" de Neil DeGrasse deixou claro.

86 Andrew Ross, Creditocracia e o Caso para Recusar a Dívida Nova York: Zero Books 2013. A frase foi cunhada por Mario Monti, antigo diretor do Banco Nacional da Itália e ex-tecnocrata (não eleito) primeiro-ministro daquele país. 
maior integração, sob modernas condições, da população mundial em uma economia na qual profissionais trabalhadores são cruciais para a produção de riqueza - e o capitalismo, no qual esse processo, para usar a frase de Veblen, é "sabotado" por sua subordinação à rentabilidade.

Se o bloco histórico financeiro global da hegemonia dos EUA se tornar anátema para o setor mais altamente qualificado dos "99\%", a alternativa russo-chinesa requereria suas habilidades e poderia se tornar relativamente autônoma de uma estrita ou puramente lógica do lucro capitalismo (embora não da lógica do conflito de poder e do estatismo, que pode ser igualmente alienante para essa classe e seus aliados da classe trabalhadora). Mas sua dependência dos combustíveis fosseis, dos rendimentos deles derivados, e do uso desses como uma importante fonte de poder, pode igualmente levar à desilusão por parte de uma classe capaz de imaginar, construir, descobrir e prover alternativas ao uso dessas, e para quem a proteção e o reparo da ecologia global está, sem dúvidas, emergindo como uma prioridade e um teste decisivo politicamente. O próprio uso da Rússia de gás e petróleo para ganhar influência e a procura da China pelo mesmo através de relações bilaterais com a África e o Oriente Médio pode não parecer moralmente superior, ao fim, à tentativa dos EUA de monopolizar esses mesmos recursos e de sua disposição de ir à guerra por tal controle. De fato, este aspecto dos governos populistas de esquerda da América Latina - a despeito da popularidade de seus programas de redistribuição e bem-estar - levou à protestos de massa e conflitos não com a direita ou a burguesia pró-EUA, mas com a própria base desses governos na Venezuela, Equador e Bolívia. A “exportação de monopólio” das agora bastante grandes corporações na China e os capitalistas estatais de petróleo e gás da Rússia provavelmente não serão dramaticamente mais agradáveis para uma classe de profissionais que procuram trabalhar para usar a ciência e o conhecimento a fim de fazer o mundo mais habitável e sustentável para todos em relação aos banqueiros e os militaristas da hegemonia global financeira dos EUA. Ainda assim, alguns aspectos de seu projeto, como a ligação infraestrutural de áreas contíguas e o uso de recursos naturais para o desenvolvimento nacional e regional e não apenas para o lucro sem preocupação com onde esse se dará, podem ser mais próximos das prioridades de uma classe preocupada com como as coisas são feitas e em fazê-las bem ao invés de com dinheiro para seu próprio bem.

Em suma, nenhum projeto hegemônico pode funcionar sem a ativa participação de cientistas, engenheiros, médicos, doutores e funcionários treinados, técnicos, pesquisadores, técnicos de laboratório, professores, especialistas em direito internacional, designers de software, professores, programadores, físicos, químicos, biólogos e assim em diante. Não está claro 
que a classe que incorpora em suas pessoas, suas habilidades e know-how precise subordinar ao futuro seu próprio trabalho e capacidade de transformar o mundo para qualquer um dos atualmente projetos hegemônicos competidores. Mas a história também demonstra que sem algum acesso ao poder político, nenhuma classe, por mais importante que seja, é capaz de sozinha afirmar hegemonia social (liderança de outras classes). Há algum sinal de circunstâncias políticas favoráveis a uma aliança de classes com um interesse em uma globalização não capitalista ou em uma transformação dos Estados nacionais e alianças que seja consistente com essas forças? A distorção da União Europeia em uma mera força para imposição da privatização e do poder das finanças através do uso da dívida pública parece ter impedido uma das mais poderosas dessas possibilidades, dada a relativa concentração de trabalhadores do conhecimento na Europa e na preocupação constante com qualidade por parte de uma grande fatia da população e da tradição cultural na Europa. O papel desses profissionais nos algoritmos matemáticos, softwares de computadores, uso de mídia social e outras técnicas em ambas as vitórias eleitorais do Presidente Obama, a despeito da traição da esperança de muitos dos apoiadores de Obama e ativistas nessas campanhas, sugere quão poderosa tal classe pode ser quando mobilizada. E, embora exagerado, o foco no uso de mídias sociais nas revoluções da Primavera Árabe e mesmo as altamente apoiadas (pelos EUA) "revoluções coloridas" nas antigas repúblicas soviéticas, protestos na Turquia e em outros lugares, parecem sugerir quão efetiva essa classe pode ser se mover-se de forma autônoma. A recente e decisiva rejeição do sexismo e racismo envolvido nas iniciativas "GamerGate" sugerem que a política está cada vez mais vindo à tona dentro dessa classe. A formulação dos “99\%" pelo Occupy explicitamente amarrou a classe média profissional à classe trabalhadora, pequenas empresas (aquelas que são sujeitas às forças de mercado diferente de grandes corporações que internalizam mercados para usá-los na exploração de fornecedores menores), artesãos, estudantes (futuros trabalhadores profissionais), pequenos agricultores, e outros setores da sociedade.

Qualquer alternativa ao capitalismo, mais cedo ou mais tarde, terá de encontrar uma maneira de confrontar diretamente o capital móvel, esse poder que permitiu que várias, específicas classes capitalistas históricas manobrassem e dominassem todos menos os mais poderosos Estados e, em qualquer caso, impusessem seus interesses nesses como aliados em sucessivos ciclos históricos de acumulação e hegemonia. A ascensão das teorias de bancos e créditos públicos, do dinheiro como uma mera utilidade pública e da "moderna teoria da moeda" - que, interessantemente (sombras do movimento para frente e para trás de Arrighi), toma certas ideias de teorias estatais da 
moeda do esforço abortado da Alemanha à hegemonia. Isso promete teorizar o sonho de Keynes de "capital como um bem livre", de rendimentos básicos garantidos a todos, como o novo sufrágio universal. O que Andrew Ross chama de "economia mista" do público e dos bens comuns (estes últimos com base na auto-gestão) pode estar se desenvolvendo como uma incrivelmente coerente expressão de práticas reais ao redor do mundo por movimentos e autoridades procurando uma saída. Todos esses são sinais esperançosos. Uma sociedade na qual as forças previamente dominantes como o capital são tornadas utilidades públicas para financiar projetos úteis e produção utilizável para as necessidades humanas pode ser uma em que houvessem distinções de status baseadas nas contribuições individuais para o bem comum, mas não por desigualdades de classe. Quero dizer desigualdades de classe no sentido ou de diferenças hereditárias e herdadas e grandes distinções em termos de riqueza, status, privilégios e poder ou acesso a esses, ou no sentido de diferenças de poder de um grupo sobre outro estruturalmente. Isso significaria uma sociedade na qual os mercados serviriam como um bem comum maior, mas não seriam utilizados como instrumentos de controle social pelas classes exploradoras, e uma onde as instituições democráticas poderiam ser os lugares onde um diálogo coletivo sobre diferenças poderia ser mediado para alcançar resultados ou benefícios para a maioria ou todos. Tal sociedade e tal ordem internacional de sociedades desse tipo pode ser chamada, justificadamente, de "uma sociedade sem classes" ou poderia ser chamada pelo nome mais tradicional para um sistema político de cidadãos cujas diferenças não resultam em desigualdades estruturais e exploração - uma república. Como Immanuel Kant argumentou, a paz mundial requer uma comunidade mundial de repúblicas, de forma e de conteúdo republicano de governar, significando diálogo aberto e abertura a críticas por parte das autoridades, com as pessoas tomando prioridade, criando um virtuoso ciclo de aperfeiçoamento contínuo de um sistema político nunca totalmente perfeito. ${ }^{87} \mathrm{E}$ Maquiavel deixa claro que mais que uma república é necessária, porque repúblicas precisam de uma dinâmica de criticismo, de imitação, de diversificação e competição, para manter a virtude e o virtuoso ciclo de interação republicana entre pessoas e autoridade, e para manter uma situação internacional criativa. ${ }^{88} \mathrm{E}$ assim, uma comunidade mundial de repúblicas baseadas em um novo bloco histórico, no-

87 Sou grato ao Massimliano Tomba, cujo trabalho vindouro eu traduzi de forma manuscrita para o inglês do original em italiano: Max Tomba, Para Além dos Direitos Humanos: Relendo Kant sobre Justiça, para esse entendimento de Kant como um republicano.

88 J. G. A. Pocock, O Momento Maquiavélico: O Pensamento Político Florentino e a Tradição Republicana Atlântica, Princeton: Princeton University Press, I975, p.88; Veja também a brilhante discussão sobre Maquiavel e republicanismo em Antonio Negri, Insurgências: Poder Constituinte e o Estado Moderno Minneapolis: University of Minnesota Press, 2009 
vas tecnologias e novas formas de organização, interagindo em um virtuoso ciclo com o mercado como instrumento para reforçar a igualdade e liberdade republicana e o bem-estar humano e não como mestres, e com a moeda feita uma utilidade pública subordinada à necessidade e criatividade humana, são as peças de um quebra-cabeça cuja perfeição assintótica progressiva, ainda que necessariamente incompleta, pode impedir a Terceira Guerra Mundial.

Mas se essas peças do quebra-cabeça, as forças em capo da nova massa de classes trabalhadoras no Sul Global ${ }^{89}$, a luta comum contra a dívida e a expropriação, contra a guerra e a degradação do meio ambiente, e a classe média profissional que incorpora os mais altos níveis de conhecimento humano, podem construir juntas uma alternativa ao capitalismo e um bloco hegemônico livre de dominação permanece a ser descoberto. O destino de tal projeto não pode ser previsto e, ainda que ele deva encontrar algum acesso ao poder político e construir um bloco histórico, a resposta a essas perguntas, e de qualquer futura ordem republicana pós-capitalista, permanece, como Giovanni Arrighi e Beverly Silver escreveram, "fundamentalmente nas mãos desses movimentos".

\section{REFERÊNCIAS}

Abu-Lughod, Janet. I989. Before European Hegemony: The World Economy. Oxford and New York: Oxford Univ. Press.

Arrighi, Giovanni, and Beverly Silver. 1999. Chaos and Governance in the World System. Minneapolis: University of Minnesota Press.

Arrighi, Giovanni. 1994. The Long Twentieth Century: Money, Power, and the Origins of Our Times. New York and London: Verso.

Arrighi, Giovanni. 2007. Adam Smith in Beijing: Lineages of the Twenty-first Century. London/New York: Verso.

Bendix, Reinhard. I974. Work and Authority in Industry. Berkely: University of California Press.

Campbell, Horace. 2008. "China in Africa: Challenging US Hegemony". Third World Quarterly 29 (I): 89-105.

Chossudovsky, Michel. 2003. The Globalization of Poverty and the New World Order 2nd. Quebec: Global Research.

Cleaver, Harry. 1980. Reading Capital Politically. Austin: University of Texas

89 Beverly Silver, Forças do Trabalho foi o trabalho pioneiro que demonstoru que a globalização não havia resultado em um declínio líquido nem no tamanho nem no poder da classe trabalhadora como tal. 
Press.

Colatrella, Steven. 200I. Workers of the World: African and Asian Migrants in Italy in the 1990s. Trenton and Asmara: Africa World Press.

Colatrella, Steven. 20II. "Global Governance and Revolution in the 2Ist Century: Strikes, Austerity and Political Crisis". New Politics I3 (3).

Colatrella, Steven. 20II. "In our Hands is Placed a Power: Austerity, Worldwide Strike Wave and the Crisis of Global Governance" Socialism and Democracy 25 (3): 82-106.

Dyson, Kenneth, and Kevin Featherstone. 1999. The Road to Maastricht: Negotiating Economic and Monetary Union. Oxford and New York: Oxford University Press.

Engdahl, William. 2004. A Century of War: Anglo-American Oil Politics and the New World Order London: Pluto Press.

French, Howard W. 20I4. China's Second Continent. New York: Knopf.

George Friedman, George. 2010. The Next Hundred Years. New York: Anchor. Goldman, Marshall. 2003. The Piratization of Russia: Russian Reform Goes Awry. London and New York: Routledge.

Haas, Ernst. I968. The Uniting of Europe: Political, Social and Economic Forces 1950-57. Stanford: Stanford Univ. Press.

Howard W. French. 20I4. China's Second Continent: How a Million Migrants are Building a New Empire in Africa. New York and Toronto: Alfred Knopf.

Keohane, Robert. 2005. After Hegemony: Cooperation and Discord in the World Political Economy. Princeton: Princeton University Press.

Krahmann, Elke. 2005. "American Hegemony or Global G;overnance? Competing Visions of International Security”. International Studies Review 7 (4): 53I-545.

Marx, Karl, and Frederich Engels. 2004. Communist Manifesto. London: The Collector's Library of Essential Thinkers.

Marx,Karl. 2000. Pre-Capitalist Economic Formations. New York: International Publishers, 2000.

McDermott, John. I980. The Crisis in the Working Class and Arguments for a New Labor Movement Boston: South End Press.

McDermott, John. I99I. Corporate Society: Class, Property, and Contemporary Capitalism. Boulder San Francisco Oxford: Westview Press.

McDermott, John. 2008. “A Mass Constituency for Globalization”. Rethinking Marxism 20 (I): I5I-I59. 
Negri, Antonio. 2009. Insurgencies: Constituent Power and the Modern State. Minneapolis: University of Minnesota Press.

Negri, Toni, and Michael Hardt. I999. Empire. Cambridge: Harvard.

Ostrom, Elinor. I990. Governing the Commons: The Evolution of Institutions for Collective Action. Cambridge and New York: Cambridge University Press.

Perrow, Charles. 2002. Organizing America Princeton: Princeton University Press.

Phillips, Kevin. 2006. American Theocracy: The Peril and Politics of Radical Religion, Oil and Borrowed Money in the 21st Century. New York: Viking.

Pirenne, Henri. "The Stages in the Social History of Capitalism”. American Historical Review i9 (3): 494-515.

Pocock, J.G.A. I975. The Machiavellian Moment: Florentine Political Thought and the Atlantic Republican Tradition, Princeton: Princeton University Press.

Polanyi, Karl. 1957. The Great Transformation. Boston: Beacon Press.

Ross, Andrew. 2013. Creditocracy and the Case for Debt Refusal. New York: OR Books.

Schumpeter, Joseph. I955. Imperialism, Social Classes: Two Essays by Joseph Schumpeter. New York: Meridian Books.

Silver, Beverly. 2003. Forces of Labor: Workers' Movements and Globalization Since 1870. Cambridge: Cambridge University Press.

Sinclair, Timothy. 2005. The New Masters of Capital: American Bond Rating Agencies and the New Politics of Creditworthiness. Ithaca: Cornell University Press.

Stavrianos, L.R. I98I. Global Rift: The Third World Comes of Age. New York: William Morris.

Strange, Susan. 1987. "Persistent Myth of Lost Hegemony". International Organization 4I (4): 55I-557.

Tilly, Charles. I992. Coercion, Capital, and European States. Oxford: Blackwell. Tomba, Max. 20I3. "Marx as the Historical Materialist. Re-reading The Eighteenth Brumaire". Historical Materialism 2I (2): 2I-46.

Veblen, Thorstein. 1923. Absentee Ownership. New York: Viking Press.

Weber, Max. I98I. General Economic History. New Jersey: Transaction Books. 


\section{RESUMO}

O presente artigo procura investigar algumas das razões por trás dos eventos que levaram a uma recente guinada nas relações internacionais em direção à geopolítica global e uma renovada competição entre as grandes potências. Busca-se apontar ideias de importantes autores e colocá-las para dialogar. Atenta-se para a possibilidade de um bloco político e econômico alternativo estar sendo construído ao redor da China frente a um declínio do poder estadunidense. Aprofunda-se tais pontos ao identificar outras características fundamentais do sistema atual que envolve a discussão de classes. A atual configuração das alianças de classe e Estados envolve a complexa dinâmica das classes trabalhadoras no Sul Global, o uso da dívida externa como forma de dominação pelo centro econômico e financeiro mundial, além da nova classe média profissional - que preza por conhecimento, tecnologia e democracia. São essas relações e sua interface com o poder político existente que permeiam o reavivamento da geopolítica global, influenciando não apenas os eventos atuais, mas também qualquer possibilidade de se pensar uma alternativa de governança e estrutura internacional - ou mesmo a falha disso e um consequente e possível novo conflito em escala mundial.

\section{PALAVRAS-CHAVE}

Terceira Guerra Mundial; Classe; Geopolítica; Hegemonia.

Recebido em 8 de abril de 2015. Aprovado em 25 de julho de 2015.

Traduzido por Ana Paula Calich e William Moraes Roberto 


\section{RELAÇÕES NAVAIS ENTRE BRASIL E REINO UNIDO DURANTE A GUERRA FRIA: O CASO DA AQUISIÇÃO DAS FRAGATAS VOSPER}

\section{João Roberto Martins Filho ${ }^{1}$}

Neste artigo analisaremos o caso da aquisição das fragatas Vosper pela Marinha brasileira no começo dos anos I970. A nosso ver o processo de compra desses navios lança luz sobre questões não apenas navais, mas de política externa, ao revelar a disputa pelo mercado militar brasileiro por parte do Reino Unido, já a partir do final dos anos i940. Desde essa data, percebe-se que os britânicos não se conformaram com o monopólio dos Estados Unidos no fornecimento de armamentos para o Brasil. Embora num contexto adverso, marcado pela disposição americana a fornecer navios obsoletos para nossa Marinha a fundo perdido, a diplomacia britânica cuidou das relações com nossa força naval, acompanhando com atenção os sinais de insatisfação na oficialidade e esperando pelo momento de retomar antigos laços que datavam da época de nossa Independência. Embora o tema não apareça em nossa literatura de relações internacionais, tanto para o Brasil como para a Grã-Bretanha, o negócio das fragatas foi considerado estratégico para a relação entre os dois países. Em nossa perspectiva, ele antecipou em alguns anos, a aproximação com a Europa situada pela literatura nos anos Geisel. ${ }^{2}$

I É professor Associado do Departamento de Ciências Sociais e do Programa de Pós-Graduação em Ciência Política da Universidade Federal de São Carlos (UFSCar). Ocupou a Cátedra Rio Branco em Relações Internacionais no King's College, Londres, e a Cátedra Rui Barbosa de Estudos Brasileiros na Universidade de Leiden, Holanda. E-mail: djrm@ufscar.br

2 Para tratar desse tema, será necessário enfrentar as temáticas da relação entre Marinha, tecnologia e política, o que inclui o entendimento do processo decisório naval, da questão da inovação contida na importação de equipamentos navais e das relações entre Estado e indústria naval nos países centrais. Nossa análise baseia-se tanto em fontes oficiais da Marinha brasileira e depoimentos colhidos pelo autor junto a oficiais navais, como em documentação diplomática britânica. Este artigo contou com apoio da FAPESP (processo 20I1/07520-4). As opiniões, hipóteses e conclusões ou recomendações expressas neste material são de responsabilidade do autor e não necessariamente refletem a visão da FAPESP. O autor é pesquisador do CNPq. 
Ao ignorar o aspecto da compra de armamentos, a literatura sobre nossa política externa no período ditatorial perdeu um aspecto crucial nas relações entre o Brasil autoritário e as democracias europeias. Os poucos autores que se concentraram na chamada "vertente europeia" de nossa política internacional tenderam a localizar sua emergência num momento posterior ao da compra das fragatas. Para eles, trata-se de um fenômeno do governo Geisel, com sua política externa de afastamento dos EUA e sua política interna de distensão. Assim, segundo um desses autores:

A aproximação com as democracias capitalistas da Europa ocidental tinha duplo propósito: significava uma grande relativização da presença dos EUA sobre o cenário político doméstico (...) e paralelamente indicava para os setores mais favoráveis à liberalização que o regime efetivamente democratizava-se, tanto que já era aceito por governos democráticos importantes33.

No entanto, no caso específico da Grã-Bretanha, é possível propor que um ponto alto nas relações comerciais se deu ainda no governo Médici, com a venda dos equipamentos militares aqui analisados, negociação que se inseria num contexto mais amplo de busca de autonomia de vários países em desenvolvimento nessa fase, o que os levava a procurar uma alternativa à transferência de material naval obsoleto, americano ou soviético. ${ }^{4}$

\section{0 processo decisório doméstico}

No caso de marinhas como a brasileira, a relativa autonomia de que gozam as Forças Armadas no interior do Estado e a falta de preocupação da sociedade e das instituições não militares com a temática da defesa fazem com que o processo decisório que leva à compra de navios de guerra e outros equipamentos permaneça fundamentalmente interno à força naval. De um modo geral, esse processo tem sua origem em ideias surgidas no interior dos setores de engenharia naval, que conseguem, ou não, convencer os escalões

\footnotetext{
Agradeço a Ludolf Waldmann a leitura atenta da primeira versão.

3 Antonio C. M. Lessa, Brasil, Estados Unidos e Europa Ocidental no contexto do nacional-desenvolvimentismo: estratégias de diversificação de parcerias: I974-I979. Dissertação de Mestrado, UNB, Brasília, I994, p.94 e p.290.

4 Sami Faltas se refere à "Indonésia e vários países latino-americanos" que "se voltaram para fontes da Europa ocidental para suplementar o seu equipamento de origem americana", antecipando um caminho depois seguido pela Índia, Taiwan e Egito. Ver Arms markets and armament policy: the changing structure of naval industries in Western Europe, Dordrecht/Boston/Lancaster, Martinus Nijhohh, I986, p.59.
} 
superiores da necessidade de efetuar aquisições. Tanto no nível dos engenheiros quanto da hierarquia surgem em geral grupos divergentes, em torno das opções colocadas na mesa e/ou da forma como adquiri-las: por doação ou por compra, neste ou naquele país. Esses grupos constituem o que chamaremos aqui de "partidos tecnológicos", que podem ou não expressar divergências mais profundas, políticas ou de estratégias navais. Uma vez assumidas pela hierarquia da Marinha, suas aspirações são levadas ao governo federal. O caso da aquisição das fragatas não foi diferente. ${ }^{5}$

Depois da Segunda Guerra Mundial, a Marinha brasileira passou a receber navios americanos de segunda mão, geralmente contratorpedeiros, praticamente doados ao país por meio dos mecanismos de lend-lease vigentes desde a época do conflito. A insatisfação com esse material, que de início constituiu um avanço tecnológico significativo para nossa Marinha, ao introduzi-la na era do rádio e dos sonares, já é visível no final dos anos 50, principalmente entre os engenheiros da Marinha. Assim, o almirante Coelho, presidente da Comissão de Construção de Fragatas no Reino Unido, no começo dos anos I970, defendeu que os navios recebidos dos EUA durante e depois da Segunda Guerra Mundial "nunca representaram necessariamente aquilo que a Marinha necessitava ter", principalmente porque foram concebidos para as necessidades de outro país e em outro contexto estratégico. ${ }^{6}$ Segundo o almirante, os EUA se surpreenderam com as aspirações brasileiras. De todo modo, desde I96I, a construção no país de navios de escolta passa a constar dos planos do Estado-Maior da Armada (EMA). Seguiram-se estudos elaborados na Escola de Guerra Naval sobre as necessidades de navios para a MB, dentro da estratégia de proteção do tráfego marítimo no Atlântico Sul.

No governo do presidente João Goulart, o EMA e o ministro da Mari-

5 As fragatas são navios de escolta, tanto para uso anti-submarino como de emprego geral. Antes de sua aquisição, o esqueleto da esquadra brasileira era composto por outro tipo de navios de escolta, conhecidos durante a guerra como destroieres de escolta e depois simplesmente como contratorpedeiros. Esses navios cumpriam basicamente funções típicas da guerra anti-submarino, estratégia atribuída ao Brasil pelos Estados Unidos, nos quadros da defesa do Atlântico Sul diante de uma eventual guerra global entre os dois lados da guerra fria. A Marinha contava também com dois cruzadores - Barroso e Tamandaré -, sendo o primeiro o navio-capitânia da Esquadra. O segundo abrigou o presidente Carlos Luz na crise que precedeu a posse de Juscelino Kubitschek, conhecida como o "golpe preventivo do general Lott". Ver Julio de Sá Bierrenbach, 1954-1964: uma década política, Rio de Janeiro, Domínio Público, I996, p.34. 6 O almirante Coelho localiza no ano de I959 os primeiros contatos com a Marinha americana no sentido de construir no Brasil, com apoio dos EUA, navios de escolta mais adequados às necessidades do país. Ver José Carlos Coelho de Sousa, Uma história das fragatas, Rio de Janeiro, Clube Naval Editora, 200I, p.8. Este livro constitui a principal fonte sobre o caso aqui examinado. Foi complementado tanto com entrevistas quanto com questionários dirigidos a oficiais diretamente envolvidos nesse processo, a partir de uma lista conseguida junto a oficiais navais. 
nha, almirante Paulo Bosísio aprovaram estudos que previam a necessidade futura de 28 fragatas para cumprir essa missão. No final de i963, o ministro Sylvio Motta apoiou a ideia de elaboração de um programa plurianual de investimentos e custeio da força, configurado no primeiro Plano Diretor naval, que apesar de suas claras limitações, "constituía afinal uma base de pensamento e de ação para a Marinha em conjunto e não apenas para um pequeno grupo de dirigentes eventuais", o que para alguns oficiais teria dado um plano à Marinha "acima das profundas divergências políticas e ideológicas que marcaram a época de sua implantação".

Com o golpe de ig64, o almirante Motta foi substituído pelo almirante Mello Baptista e os planos anteriores foram temporariamente suspensos, por terem como patrono um almirante que fora ministro no regime deposto. A gestão de Baptista expressou os pontos de vista dos setores mais radicais da Marinha. À mesma época, o marechal Castello Branco nomeou o ex-ministro Paulo Bosísio para o lugar do marechal Taurino de Resende na etapa final da Comissão Geral de Investigações encarregada de recomendar cassações de direitos de militares e políticos acusados de vínculos com o governo Goulart. No contexto da época, Bosísio era visto como um moderado. ${ }^{8}$

Logo depois, em janeiro de $1_{9} 65$, o presidente o traz de volta ao ministério da Marinha, em meio à crise entre esta força e a FAB, dada a decisão presidencial de reservar os meios aéreos das três forças à Aeronáutica - a chamada "crise da aviação embarcada", considerada por Viana Filho "a mais longa e mais trabalhosa das crises" até então enfrentadas pelo general presidente. 9 Segundo o chefe da Casa Civil de Castelo, o almirante concordava com o espírito da mudança proposta pelo presidente: "Para ele, a solução atendia

7 Mozart Padilha de Souza, “O Plano Diretor: realidades e perspectivas da Marinha”, Revista Marítima Brasileira, 2. Trimestre I97I, p.I08-II4, p.IIo.

8 Luís Viana Filho o caracteriza como "ilustre oficial da Marinha" prudente e moderado e apoiador da medida tomada por Castello Branco de atribuir à Força Aérea a exclusividade da aviação embarcada, como providência adequada à racionalização dos meios. Ver O governo Castelo Branco, Rio de Janeiro, Biblioteca do Exército e Livraria José Olympio Editora, I975, vol. I., p. 202. Cf. também John W. Foster Dulles, President Castello Branco: Brazilian Reformer, College Station, Texas A\&M University Press, I980, p.78 e segs.

9 Ver op. cit., p.204. Datado de 6 de janeiro de I965, documento da embaixada dos EUA ao Departamento de Estado relata conversa com o comandante Julio Pessoa, ajudante de ordens do Presidente Castelo Branco. Para Pessoa, "o Presidente não seria popular na Marinha porque defende a criação de um Ministério da Defesa”, mas Castelo "não sente que tal insatisfação subiria a níveis perigosos". Ainda segundo a versão americana sobre a conversa com o oficial brasileiro, o Presidente avaliaria que o MD era uma necessidade econômica e acabaria por ser criado, mas considerava que a oposição da Marinha seria capaz de barrá-lo no momento. Àquela altura, Castelo pretendia manter o ministro Mello Baptista, apesar dos boatos sobre seu afastamento. "Airgram n. A-697", cedido generosamente ao autor pelo pesquisador Carlos Fico. 
ao princípio da economia de meios, evitando a existência de aviões da Marinha e do Exército, e assegurava a cobertura aérea necessária às forças de Superfície e Submarinas, da Marinha, uma vez que os aviões da Esquadra, embora pertencentes à FAB, obedeceriam ao comando da Força Naval, quando em operações". ${ }^{\text {Io }}$

Mas a Marinha estava tensa. A posse do ministro foi marcada por violento discurso de seu antecessor. Bosísio assumiu como partidário da unidade: "Dois aspectos - disse ao tomar posse - nortearão a minha administração: a união da Marinha e a coesão dentro da classe; e a união da Marinha com as demais forças armadas". ${ }^{\text {II }}$ Mello Baptista representava desde meados dos anos I950 a direita extremada, mais afeita à política que à própria modernização da força. ${ }^{12}$ Em junho de I965, o principal aliado do almirante Motta, o almirante Rademaker, foi punido pelo novo ministro, com apoio de setores significativos da oficialidade, por divulgar críticas ao governo Castello BranCo. $^{\text {I3 }}$

A posse do ex-ministro de Goulart acabou por se revelar um passo indispensável para a modernização naval. O contexto mais amplo foi dado pelo avanço dos métodos administrativos adotados pelo novo regime, principalmente o conceito de orçamento-programa, importado dos EUA. ${ }^{14}$ Nesse quadro, o ministro Bosísio retomou o Plano Diretor já mencionado. ${ }^{15}$ Foi

Io Luís Viana Filho, op. cit., p.203. A partir da decisão presidencial, a Marinha manteria os helicópteros e a FAB ficaria com os aviões de asa fixa.

II Citado em Viana Filho, op. cit., p.204. Ver também Foster Dulles, op. cit., p.II4.

I2 O ex-presidente Geisel lembrou em seu depoimento aos pesquisadores do CPDOC que o almirante integrava, desde os anos I950, com seus colegas Rademaker, Aarão Reis, Saldanha da Gama e Mário Cavalcanti, o "grupo das Dionnes", a linha mais dura da Marinha, numa referência às cinco gêmeas nascidas no Canadá. Ver Maria Celina D’Araujo e Celso Castro (orgs.), Ernesto Geisel, Rio de Janeiro, Editora Fundação Getúlio Vargas, I997, p.219.

I3 Idem, p.I42. Rademaker seria depois ministro da Marinha do governo Costa e Silva, compondo em ig69 o triunvirato militar que substituiu o presidente quando este se afastou por motivos de saúde, até a posse do general Médici. No governo deste, foi vice-presidente.

I4 Para a Marinha, tais esforços foram "precursores da sua implantação na administração pública brasileira, antecipando-se à sua adoção pelo Executivo". Ver Mauro Brasil, "Considerações sobre o Plano Diretor da Marinha”, Revista Marítima Brasileira, 2. Trimestre I971, p.II5-I28, p.II6.

I5 Segundo uma fonte da Marinha, "a ênfase dada ao planejamento e à disciplina orçamentária como instrumentos de ação global do Governo possibilitaram que ele renascesse logo em ig 65 , com perspectivas ampliadas. As novas políticas e diretrizes foram estabelecidas, orientando a formulação de Planos Básicos. Houve decidido empenho em dar ao Plano Diretor uma estrutura permanente, através da elaboração de uma Sistemática Detalhada e da criação de um Grupo de Coordenação e Controle, subordinado à Secretaria Geral da Marinha" (grifos do autor), v. Mozart Padilha de Souza, op. cit., p.IIo. Outro autor lembra que "ao final do ano de ig66, uma comissão designada pelo então Ministro da Marinha dedicou-se ao trabalho de revisão 
criado grupo separado das diretorias técnicas existentes na Marinha, apenas para cuidar das construções navais. Esse grupo deveria definir, pela primeira vez na história da Marinha, o tipo de navios que se queria construir e orçar o plano de aquisições para encaminhamento à Presidência da República. ${ }^{\mathrm{I}}{ }^{\mathrm{D}} \mathrm{aí}$ surgiria o Programa Decenal da Marinha de I967. Não há indícios de que esse plano estivesse vinculado a qualquer revisão da doutrina estratégica naval, então centrada na guerra anti-submarino. Os fatores que o originaram estavam mais relacionados às dificuldades colocadas pelos EUA à aquisição de equipamentos mais modernos, visíveis principalmente depois dos obstáculos colocados pelo Congresso americano às vendas militares para a América Latina, no contexto do conflito entre os poderes Legislativo e Executivo, por motivo da condução da guerra no Vietnã. ${ }^{17}$ Questões como a proibição de uso de equipamento americano contra navios, mesmo pesqueiros, da mesma origem e a dificuldade de conseguir peças de reposição para os navios antiquados transferidos pelos EUA também pesaram na decisão. ${ }^{18}$

O Programa Decenal previa a construção de io fragatas, além de outros 13 tipos de embarcações. ${ }^{19}$ Com relação às primeiras, a diretriz inicial

da sistemática do Plano Diretor, com o propósito de remover as falhas até então observadas e de harmonizar o planejamento da Marinha com a técnica de orçamento-programa". Nesse processo, o PD deixou de ser visto como um documento, passando ser encarado como uma sistemática de planejamento. Mauro Brasil, op. cit., p.Iı8.

I6 Coelho de Sousa, op. cit., p.I3-I5.

I7 Ver João Roberto Martins Filho, "As políticas militares dos EUA para a América Latina, I947I989”, Teoria \& Pesquisa, 46: IOI-I35, jan. 2005. Com efeito, documentação diplomática americana mostra desde I966 um clima tenso entre o Brasil e os EUA no tema dos armamentos. No final de I966, documento da Embaixada do Brasil em Washington, escrito em português e disponível nos arquivos diplomáticos dos EUA menciona "o estabelecimento de restrições no auxílio militar à América Latina impostas pela Lei 89-583 de i9 de setembro de i966”. Ver "Aide-Mémoire", Washington D.C., em 27 de outubro de I966, cedido ao autor por Carlos Fico. I8 Para o comandante Fernando, a constatação de que a aludida proibição poderia criar problemas às ações de fiscalização da pesca em águas territoriais brasileiras emergiram a partir da chamada "guerra da lagosta", conflito surgido com a França, no começo dos anos ig6o. Quanto às dificuldades na área de manutenção, a mesma fonte menciona a prática da Marinha americana de passar seu estoque de peças de navios retirados de serviço a dealers privados, o que encarecia muito sua aquisição. Depoimento do comandante Fernando Costa ao autor, Rio de Janeiro, Clube Naval, I5 de julho de 2008. Ludolf Waldmann Júnior lembra que, com a guerra da lagosta, os EUA acabaram ficando numa situação inusitada: ou apoiavam a França - então parte da OTAN - ou o Brasil devido à existência do TIAR. Ao final, decidiram exigir que o Brasil não utilizasse os navios arrendados. Nosso país rejeitou a exigência mencionando o TIAR em sua defesa. Ver "Tecnologia naval e política: o caso da Marinha brasileira na era dos contratorpedeiros, I942-I970”, Dissertação de Mestrado, UFSCar, 20I3, p.ıı9.

I9 Para o então capitão-de corveta Paulo Lafayette Pinto o programa inicial previa a aquisição de 20 fragatas. O oficial apresenta quadros comparativos dos planos original e do que foi efetivamente aprovado pelo governo Castello Branco em "A Marinha e a construção de navios 
do EMA determinava que deveriam já estar em serviço nas respectivas marinhas. ${ }^{2 \circ}$ Estaleiros da Holanda, Alemanha e Estados Unidos enviaram convites à Marinha para visitas. Em julho de I967, os então comandantes Coelho e Vidigal são nomeados pelo almirante Rademaker, agora ministro da Marinha do governo Costa e Silva, para visitar quatro países. ${ }^{2 \mathrm{I}}$ Em agosto, em reunião com o ministro, resolve-se fazer contatos com a U.S. Navy para fabricação de duas fragatas da classe Bronstein no Brasil.

Nessa altura, começou a ficar claro para os oficiais envolvidos que os Estados Unidos, ao se mostrarem pouco dispostos a solucionar o problema do financiamento, não tinham interesse em atender às expectativas do Brasil. Nesse quadro, o secretário-geral da Marinha, almirante Adalberto de Barros Nunes, formou um grupo de trabalho com representantes de todos os setores do governo que teriam que aprovar o financiamento externo. O GT torna-se em seguida comissão interministerial. Em agosto de 1968, um ano depois da escolha da Bronstein, os EUA não tinham apresentado proposta de financiamento. Segundo o relato do almirante Coelho, o apoio do almirante Nunes (agora na chefia do EMA) e dos almirantes Carlos Auto e Hernani Goulart Fortuna (Membros do EMA) foi decisivo para a decisão de rever a ideia da aquisição de fragata já em uso. Decide-se então pela compra de um navio de desenho novo, dotado de equipamentos que constituíssem state of the art, "na fronteira da tecnologia" e com especificação própria. ${ }^{22}$

A decisão constituía um marco na história da Marinha. ${ }^{23}$ Novas negociações com os EUA confirmaram que a questão do financiamento não se resolveria, fortalecendo a posição pró-Europa do almirante Nunes. ${ }^{24} \mathrm{Com}$ a

de guerra no Brasil", Revista Marítima Brasileira, 2 trimestre de I974, pp. 19-44. Conforme o comandante Fernando Costa, chefe de gabinete do chefe do EMA, almirante Moreira Maia à época, a aprovação desse programa foi "o último ato governamental assinado pelo presidente Castelo Branco e foi levado a ele pelo ministro Roberto Campos”. Depoimento citado.

20 Coelho de Sousa, op.cit.,p.r6.

2I Nessa ocasião, foram examinadas as fragatas Hamilton (EUA), Leander (Grã-Bretanha), mas não a Van Speik (Holanda) e a Köln (Alemanha), que não estavam no porto. Idem, p.22-25. Neste texto seguiremos a praxe naval de chamar de "tenentes" os três postos iniciais da carreira; de "comandantes" os postos de capitão de corveta, capitão de fragata e capitão-de-mar-e-guerra e de "almirantes", os três postos de oficial-general da Marinha.

22 Basicamente, isso significava que a propulsão seria a mista CODOG (Combined Diesel or Gas Turbine) e gás, e a fragata contaria com sistemas táticos navais computadorizados, lançadores de foguetes IKARA, helicópteros antissubmarinos com torpedos MK-44, sistemas de sonares avançados, torpedos antissubmarino, mísseis de defesa anti-aérea Seacat. Coelho de Sousa, op. cit., p.33-37.

23 Para Coelho de Sousa, acabava-se, assim, "com o complexo de cobaia, que levou no passado a escolhas excessivamente tímidas e ultra-conservadoras". Ver op. cit., p.33.

24 A se acreditar na documentação diplomática britânica que examinaremos depois, o almi- 
crise da sucessão do presidente Costa e Silva, em setembro-outubro de i969, a última decisão do ministro Rademaker foi o cancelamento da escolha da Bronstein e o rompimento com a opção americana. ${ }^{25}$

No início do governo Médici, graças ao trabalho dos oficiais acima citados, o agora ministro Adalberto Nunes elaborou exposição de motivos pedindo autorização para contratar financiamento de até US\$ 250 milhões para a compra de io fragatas. Como veremos adiante, nos bastidores diplomáticos, a Grã-Bretanha já tinha apresentado termos de financiamento atrativos, no bojo das negociações para a compra pelo Brasil dos submarinos da classe Oberon. O presidente deu sinal verde. O EMA aprovou então a folha de especificações, enviadas a estaleiros no exterior. Os principais estaleiros europeus interessaram-se pelo assunto. ${ }^{26}$ Depois de novas visitas a estaleiros europeus, a Diretoria Geral de Material da Marinha escolhe como finalistas as firmas Vickers, Yarrow, Vosper Thornicroft e Blohm und Voss. Fica claro nessa altura que os US\$25 milhões disponíveis para as aquisições seriam suficientes apenas para a compra de 6 fragatas. No final, segundo a versão oficial da Marinha, pesaram as condições de financiamento: decide-se comprar as fragatas na Inglaterra, junto ao estaleiro Vosper. ${ }^{27}$ Contudo, essa versão deve ser tomada com cuidado. Nas grandes aquisições navais, nem sempre impera essa racionalidade. Como veremos a seguir, ao examinar a documentação diplomática britânica, setores influentes da Marinha tinham preferência há algum tempo pela Vosper.

Em junho de I970, uma delegação brasileira foi à Inglaterra para comunicar à Vosper a intenção da Marinha em adquirir seis fragatas. Dela participaram os almirantes Coelho e Alcântara e os membros do grupo inter-

rante Nunes não era apenas pró-Europa, mas decididamente pró-britânico. De toda forma, era um partidário decidido da autonomia em relação aos EUA. Na aula inaugural que proferiu a 30 de abril de 1970 na Escola de Guerra Naval, ele aludia "às exigências impostas pela necessidade da criação de um Poder Naval efetivo e nosso (grifo dele) - condizente com a realidade e as possibilidades nacionais", para defender a otimização dos processos administrativos. Ver Mauro Brasil, op. cit., p.II6.

25 Idem, p. 38.

26 No Reino Unido, Swan Hunter, Cammell Laird, Scotts, Yarrow, Vosper Tornycroft e Vickers; na Alemanha, Blohm und Voss associada a sua maior rival Howaldtswerke-Deutsche Werft; na Itália, Vantieri navale del Tirreni e Riuniti, e na Holanda o Verolme. Idem, p.40.

27 Idem, p.40-45. Para o comandante Fernando, "o que veio aqui para ser negociado não foi a fragata Marca-10, foi a fragata Marca-11, que é a classe que os argentinos compraram, a classe Hercules. Esse era o projeto que a Vosper estava desenvolvendo com o MOD - eu embarquei numa fragata dessas, da classe Amazon, projeto que foi comprado e comissionado e funcionou bastante tempo para a Marinha inglesa. As Marca-11 eram um pouquinho maiores que as Mar$c a-10$. A diferença era mais de conceito, de armamento, etc., mas era um projeto que dado pelo MOD à Vosper. A opção brasileira foi pelas Mark-10. Depoimento citado ao autor. 
ministerial citado acima. Segundo o primeiro, a decisão de fazer duas fragatas no país, em resposta à postura do estaleiro de que não tinha interesse em construir mais que quatro navios para um só cliente, foi tomada de improviso, não constituindo aspecto intencional de política de autonomia tecnológica. ${ }^{28}$ Assim, das seis fragatas, quatro seriam fabricadas nos estaleiros de Woolston, perto de Southampton, e duas no Arsenal da Marinha do Rio de Janeiro (AMRJ). No exame posterior da documentação britânica esse aspecto será confirmado.

Em agosto, fica pronta a versão final do contrato, assinado com pompa e circunstância, como veremos na próxima parte. O negócio foi visto à época como "o maior realizado pelos estaleiros da costa sul e provavelmente o maior de qualquer firma britânica”, garantindo trabalho naquelas instalações até I979. O financiamento de cerca de Ioo milhões de libras foi assegurado por um consórcio de oito bancos britânicos. ${ }^{29}$ A fragata Niterói (F-40), que deu nome à classe no Brasil, foi lançada ao mar a 8 de fevereiro de 1974 e incorporada a 20 de novembro de 1976 , seguida depois pelas Defensora (F-4I), Constituição(F-42) e Liberal (F-43). No Brasil, seriam construídas a Independência (F-44) e a União (F-45). Os nomes homenageavam os navios que fizeram em I822 e I823 a guerra pela Independência, mas alguns poderiam soar irônicos, dado o regime político em vigor no Brasil.

\section{Dos Estados Unidos à Grã-Bretanha}

A compra dos navios na Grã-Bretanha marcou o fim de uma era. Pela primeira vez desde o início da Segunda Guerra Mundial, os navios que constituiriam o esqueleto da esquadra brasileira eram adquiridos na Europa, encerrando na prática a fase dos contratorpedeiros obsoletos transferidos ao país por lend-lease..$^{30}$ De certa forma, a aquisição das fragatas representava uma volta ao período anterior à Primeira Guerra Mundial, quando o Brasil comprou

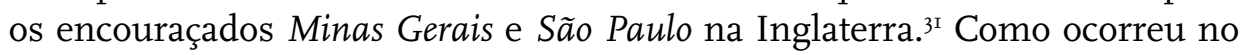
começo do século XX, no início dos anos I970 as compras navais constituí-

28 Idem, p.64-66. Para o almirante Armando Vidigal, "a decisão, portanto, não decorreu de uma deliberada tentativa de adquirir a tecnologia de construção desses navios". Ver A evolução do pensamento naval estratégico brasileiro: meados das décadas de 70 até os dias atuais, Rio de Janeiro, Clube Naval, 2002, p.II.

29 "Vosper to sell Brazilian Navy £ Ioom frigates", The Times, September 30 I970.

30 Como veremos, uma exceção a essa regra foi a venda ao Brasil em meados dos anos I950 do porta-aviões Leviathan, ainda em construção, aqui batizado Minas Gerais.

3I Ver João Roberto Martins Filho, A Marinha brasileira na era dos encouraçados, 1895-1910, Rio de Janeiro, FGV, 2010 . 
ram tema crucial nas relações entre nosso país e a Grã-Bretanha.

Conforme afirmou em suas memórias o embaixador britânico no Brasil à época, as exportações britânicas dobraram na passagem da década de I960 para a de I970, e "isso foi muito ajudado por compras governamentais, como, por exemplo, as feitas pela Marinha brasileira". No mesmo livro, o diplomata comemora a volta da Marinha brasileira à influência britânica: "Esta força admirável é não só modelada estreitamente pela Royal Navy em material de uniforme, mas tem igualmente uma grande tradição de comprar navios da Grã-Bretanha”. E continua: "Quando eles decidiram substituir seus navios obsoletos, fomos afortunados em ter um excelente tipo de fragata, que era justamente o que precisavam; também compraram três submarinos nossos". ${ }^{22}$

Mais de duas décadas antes, no início de I948, depois da venda de I30 aviões militares para a Argentina, a diplomacia britânica chamava a atenção para a nova situação: "Com essa política de praticamente se descartar de material bélico, parece que os ministérios militares dos EUA encontraram um meio de puxar o tapete sob os pés de qualquer concorrente, assegurando assim que a A.L. seja reequipada exclusivamente com equipamentos dos EUA". ${ }^{33}$ O dilema britânico na América Latina foi assim resumido por sua diplomacia: "Poucos dos maiores países estarão dispostos a vincular-se exclusivamente às rodas da carruagem americana. Nosso problema é reter uma parcela razoável do comércio de armas com a A.L. sem indispor indevidamente os americanos". 34

Durante o governo Dutra (I945-I950), porém, não foi possível mudar o novo quadro. Apenas, com a posse de Vargas, o embaixador britânico viu perspectivas de melhora. ${ }^{35}$ No entanto, com a assinatura do Acordo Militar Brasil-EUA, a I5 de março de I952, logo ficaria claro que a nova superpotência não estava disposta a permitir que a Grã-Bretanha conseguisse recuperar a

32 Sir David Hunt, Memoirs: military and diplomatic, London, Trigraph, 2006, p. 3II.

$33 \mathrm{FO} 37 \mathrm{I} / 68277$, citado em Moura, "From 'automatic alignment to 'difficult pragmatism': shifts in Brazilian foreign policy and their impact on Anglo-Brazilian military contacts, I945I954", London School of Economics \& Political Science, M.A. International History, september, I994, p.II. Em seu relatório para o período de janeiro de I946 a março de I947, o adido aeronáutico britânico em nosso país mencionava possíveis resultados dos contatos a serem feitos entre o ex-adido naval da Grã-Bretanha no Brasil, agora representante da firma Hawker e o alto escalão da FAB (FO37I/6I2I5, citado em Leandro Moura, p.I2. No relatório do mesmo adido para o ano de I949, aparecem novas esperanças de vendas de material aeronáutico ao Brasil (FO37I/8I290, citado em idem).

34 FO37I/6I305, citado em Leandro Moura, op. cit., p.9.

35 Ao comentar entrevista do presidente eleito, em outubro de I950, onde este sugeria que o Brasil poderia procurar a Europa quando não fosse atendido pelos EUA em suas expectativas de assistência econômica e técnica. Moura, op. cit., p.I2. 
antiga posição de fornecedora de armas para o Brasil. Contudo, o caráter obsoleto dos equipamentos cedidos ao Brasil estimularia o Foreign Office a não abandonar suas expectativas de exportar material bélico mais moderno para nosso país. O esforço acabou rendendo, no final de I952, a venda de 70 aviões Meteor à $\mathrm{FAB} .{ }^{36}$ No que diz respeito à Marinha, à mesma época, o adido naval britânico no Rio de Janeiro avaliava: "Não podemos esperar que a Missão Naval dos EUA no Brasil receba bem nossa concorrência, mas não há razão pela qual devamos perder bons negócios por conta das suscetibilidades dos americanos". ${ }^{37}$

Já em março de I945, o Foreign Office avaliava que era fundamental manter um adido naval no Brasil. Com a criação desse posto, logo se conseguiu que o Brasil tivesse seu próprio adido naval em Londres..$^{38}$ Como vimos, porém, nos primeiros anos após a guerra o attaché arou em solo infértil, embora não sem expectativas de colheitas futuras. Em seu relatório sobre o período de janeiro de 1946 a junho de 1947, ele se referia aos rumores de que o Brasil teria interesse em adquirir "um porta-aviões moderno de menor dimensão", visto como "absoluta necessidade por sua Marinha", embora nada de concreto tivesse sido feito nesse sentido. ${ }^{39} \mathrm{Em}$ fevereiro de I952, o adido naval de Sua Majestade referia-se ao interesse brasileiro em concretizar seu programa de construções navais, o que, na visão dos brasileiros, poderia "restabelecer a tradição política de ter unidades da Marinha brasileira construídas outra vez nos estaleiros britânicos".$^{\circ} \mathrm{O}$ programa citado previa a compra de dois cruzadores leves, um ou dois porta-aviões, 6 contratorpedeiros e Io caça-minas.

Com efeito, o final de 1952 testemunhou a troca de cartas entre o adido naval no Rio de Janeiro, H.C. Ranald ${ }^{4 \mathrm{I}}$, e vários departamentos governamentais em Londres - Foreign Office, Almirantado, Ministério da Defesa, Departamento do Tesouro - tendo como tema a venda dos seis contratorpedeiros e a concorrência colocada principalmente pela França, que estaria disposta a

36 Moura, op. cit., p.I5.

37 ADMr66/6065, citado em Moura, op. cit., p.I6.

38 Moura, op. cit., p.7.

39 Moura, op. cit., p.I2. Ludolf Waldmann registrou que, já em I944, Getúlio Vargas pediu aos EUA a transferência de dois porta-aviões. É a primeira vez que a aquisição desse navio aparece desde o programa naval do então ministro da Marinha, almirante Alexandrino, em I922. Em seguida, em seu relatório ministerial de I945, o almirante Guilhem vai apresentar um programa naval que previa a aquisição de dois navios aeródromos ligeiros da classe Independence, por meio de cessão dos EUA. Ver op. cit., p.. 86-88.

40ADMir6/6065, citado em Moura, op. cit, p.r4.

4I Em documento de I954, alude-se ao mesmo oficial como adido naval, militar e aeronáutico. 
realizar o negócio com o uso do esquema barter with compensation, vale dizer, com o recebimento de parte do pagamento em mercadorias, esquema não oferecido pelo governo britânico. Naquela altura, o adido também considerava como competidores de seu país a Holanda e os EUA. Três estaleiros britânicos - Armstrong, Yarrow e Samuel White - associaram-se para apresentar proposta ao Brasil. $4^{2}$ Mas as negociações não progrediram e o programa foi cancelado.

Em abril de I954, a embaixada britânica no país admitia com realismo os termos em que se colocava a questão. No ofício que acompanhava o relatório anual do adido britânico, o embaixador no Rio de Janeiro, Sir Geoffrey Thompson, reconhecia que, em sua visão, nossa Marinha não tinha importância estratégica para o governo de Sua Majestade, “uma vez que os Estados Unidos assumiram a responsabilidade pela reorganização da defesa desta parte do mundo". E concluía: “Hoje, portanto, a Marinha brasileira é basicamente de interesse para nós como possível mercado para a venda de navios e barcos auxiliares britânicos". Em seguida, o embaixador resumia o quadro geral das relações navais anglo-brasileiras depois da assinatura dos acordos militares Brasil-EUA:

A principal dificuldade em oferecer a venda de navios e outros equipamentos navais à marinha brasileira é que os Estados Unidos, ansiosos por manter a marinha brasileira estreitamente atada à sua, tão logo ouvem falar de concorrência britânica, tendem a oferecer equipamento similar a preços nocauteantes e se o fazem não há claramente nada que nós ou qualquer outra potência europeia possa fazer. Não obstante, penso que vale continuar a apresentar propostas quando aparece a ocasião, uma vez que sempre é possível que a marinha brasileira possa colocar uma requisição no Reino Unido e, se e quando isso ocorrer, nos beneficiaríamos economicamente e também ganharíamos algum dividendo em um leve acréscimo de influência. 43

\footnotetext{
42 À época as usuais acusações de práticas de corrupção nas negociações foram feitas pelo adido: "O fato mais importante que veio à luz desde meu relatório de 4 de novembro foi a concordância por parte dos três agentes britânicos de desviar um por cento do valor do contrato para o bolso do homem que está em posição de aconselhar o Ministro da Marinha sobre a proposta a ser aceita!” (H.B.M. Naval Attaché, Rio de Janeiro to The Director of Naval Intelligence, Admiralty, Ioth December, I952). Ver os ofícios em ADM I-23976, Sale of British warships to Brazilian Navy.

43 "British Embassy, Rio de Janeiro, to Anthony Eden, Foreign Office", April I2, I954. FO 37II08850, Annual reports for 1953 and 1954 for Brazilian Navy. No relatório datado de 3I de março de I954, o adido se refere e rumores sobre ofertas provenientes de França (destroieres e porta-aviões), Holanda (destroieres), Japão (porta-aviões), Itália (submarinos) e do próprio Reino Unido (os seis navios acima mencionados e "o casco incompleto do porta-aviões leve Leviathan").
} 
Por fim, o embaixador registrava as boas relações entre as duas marinhas, usando como exemplo a boa vontade brasileira em permitir escala em seus portos dos navios britânicos em trânsito para e das Ilhas Falkland, ao contrário do que ocorria com as marinhas chilena e, obviamente, argentina. No relatório datado de fins de março de I954, o adido expressava o desconsolo de uma força naval que já fora a mais poderosa do mundo e agora tinha que se contentar com um lugar subordinado face ao poder naval dos EUA:

A Marinha é muito simpática à Grã-Bretanha e tem grande respeito e admiração pela Royal Navy e suas tradições. A Marinha brasileira gostaria de ter como modelo a nossa porque percebe que, para não falar de tradição e experiência, nossos métodos são mais econômicos em pessoal e, portanto, mais adequados às necessidades brasileiras. Nas atuais circunstâncias isso não é possível e a Marinha brasileira é no presente pesadamente doutrinada com ideias americanas. ${ }^{4}$

De todo modo, o início de I954 foi tomado pela questão da possível compra de um porta-aviões leve pela Marinha do Brasil. As razões estratégicas dessa aquisição foram explicadas ao Foreign Office pelo embaixador britânico no Rio de Janeiro:

As chances de isso ocorrer parecem remotas, mas do ponto de vista político deve ser levado em consideração que o Brasil está muito ansioso para atingir o status de potência importante (major power) e que o acréscimo de um porta-aviões à esquadra brasileira contribuiria substancial e poderosamente para esse fim e os capacitaria a ficar um ponto acima dos argentinos. ${ }^{45}$

Com efeito, em janeiro de I954, o adido naval britânico relatou ao Departamento de Inteligência Naval em Londres contatos oficiosos provenientes do EMA no sentido de sondar a Marinha britânica sobre a possibilidade de oferta do porta-aviões Hercules ao Brasil. ${ }^{6}$ Para o adido, as principais razões dessa opção seriam: I) que tal navio seria essencial para uma marinha moderna; 2) razões de prestígio (não admitidas); 3) a melhor qualidade dos navios

44 "Naval attaché, British Embassy, Rio de Janeiro to British Ambassador, Sir Geoffrey Thompson", FO 37I-I08850.

45 “British Embassy, Rio de Janeiro do American Department, Foreign Office”, January 8 i954. FO 37I-I08849, Negotiation for sale of aircraft carrier to $B N$.

46 O navio era avaliado em 2 milhões de libras no estado de construção em que estava, prevendo-se mais 4 milhões de libras para completá-lo, o que deveria ocorrer apenas no final de I957, como o adido afirmava ter relatado não oficialmente à Marinha brasileira "meses antes". 
britânicos; 4) o preço acessível do Hercules; 5) a possibilidade de estender o pagamento pelo período em que este estivesse sendo concluído.47 Segundo a fonte britânica, o chefe do EMA, almirante Atila Monteiro Aché, precisava com urgência de uma carta do adido explicitando a oferta do Hercules, que ele pretendia apresentar ao ministro Guillobel, como parte de um documento onde se expunham pontos que na visão dos almirantes do EMA deveriam ser mudados na política do ministério. A resposta do adido traz mais uma vez à luz as tensões navais anglo-americanas: segundo o oficial britânico, ele explicou ao almirante brasileiro que, se o Almirantado o autorizasse a escrever a carta, ficava subentendido que esta "não seria utilizada como um pano vermelho para enfurecer o touro americano, levando à oferta de um porta-aviões grátis, ou barato, ou um empréstimo por vinte anos, conforme rumores" que teria ouvido.

Em resposta, o almirante brasileiro teria dito que os EUA jamais forneceriam o porta-aviões ao Brasil, pois já tinham deixado claro que, em sua visão, o Brasil não precisava "de aviação naval, quanto mais de um porta-aviões”. Tal afirmação estaria ancorada na estratégia americana de destinar ao Brasil apenas a tarefa de escoltar comboios de suas costas ao Caribe, deixando o resto à Marinha dos EUA e seria vista pelos brasileiros como atitude "egoísta e arrogante". Para o adido de Sua Majestade: "A Marinha brasileira não quer ser tratada puramente como um instrumento naval dos EUA e considera que o Brasil deve estar adequadamente armado para lutar guerras privadas se o desejar, sem o auxílio americano". ${ }^{8}$ Por fim, o adido arriscava uma avaliação

47 Segundo o adido, o mensageiro do EMA foi o Diretor de Aviação Naval, almirante Olavo de Araujo, para quem era visão do EMA que o ministro Guillobel estaria se tornando "demasiado político, em detrimento dos verdadeiros interesses da Marinha”. O ponto principal de ataque era a construção de numerosas bases navais, sem que a Marinha tivesse os navios para utilizá-las, ao invés da aquisição de ıo helicópteros e do porta-aviões. Para o adido, a revelação dessas divergências foi bem mais do que esperava ouvir. "Naval Attaché, Rio de Janeiro, to The Director of Naval Intelligence, Admiralty”, IIth December I953. Para uma defesa da construção dessas bases ("para uma força do futuro, própria a uma grande potência naval e não para o Brasil atual"), ver Renato de Almeida Guillobel, Algumas apreciações sobre a administração naval, Rio de Janeiro, Imprensa Naval, I959, p.I6. As bases em questão foram construídas em Val De Cans (Pará), Recife, Natal e Aratú (Bahia).

48 Em I969, um relatório norte-americano afirmaria que a força naval brasileira tinha expectativas de se transformar numa "força pequena, mas moderna" e mencionava a opinião de "pelo menos um alto oficial naval", para o quem "Brazil's Navy officers could not sit on the beach and watch US Navy units patrolling its waters". Ver U.S. Department of State, Director of Intelligence and Research, Research Memorandum, RAR-I4, August 25 I969. Dez anos antes, o titular da pasta da Marinha no segundo governo Vargas referia-se aos compromissos assumidos pelos americanos durante a Segunda Guerra Mundial, "dos quais com o correr dos tempos e bem de acordo com seu costumeiro procedimento para conosco, tão facilmente se esqueceram". Ver Guillobel, op. cit. , p.6. 
da postura do ministro Guillobel, dividido, em sua visão, entre o desejo de marcar sua gestão pela compra do almejado porta-aviões e as pressões do chefe da missão naval americana, almirante Whitehead, no quadro de escassez de reservas que colocava o ministério da Marinha contra o Ministério das Finanças.

O ofício do adido solicitava aprovação do Almirantado e do Gabinete para escrever a carta solicitada e concluía aludindo às compras de material aéreo que deveriam se seguir à aquisição o porta-aviões. Alguns dias depois, a embaixada no Rio de Janeiro escreveu ao Foreign Office alertando que a demora na resposta colocava o adido em má situação com o chefe do EMA. Evidenciando a importância que o governo britânico conferia à venda, a resposta de Londres veio de imediato: "You may tell Brazilians that Leviathan is available". ${ }^{49}$ Três semanas depois, a embaixada comunicava a Londres que no dia 4 de fevereiro o presidente Vargas autorizara o Ministro da Marinha a comprar o Leviathan, ao custo de 7 milhões de libras. ${ }^{50}$ Seguiu-se intensa troca de correspondência entre o Rio e Londres dada a constatação de que o preço correto seria 9,9 milhões de libras, o que chocou o EMA. Finalmente, a 25 de fevereiro de I954, chegou às mãos da Marinha brasileira o memorando do Almirantado oferecendo formalmente o navio. ${ }^{51}$ Em dezembro de 1956 , já no governo Kubitschek, foi concluída a aquisição de um navio da mesma classe, o Vengeance, aqui batizado Minas Gerais. ${ }^{2}$

No relatório do novo adido naval britânico para o ano de I954, além de relatar as mudanças, a seu ver positivas, ocorridas no comando da Marinha ocorridas depois do suicídio de Getúlio Vargas, volta-se a falar do suposto desejo de partes da oficialidade naval em escapar da camisa de força da ajuda norte-americana: "Há um sentimento crescente entre numerosos oficiais navais brasileiros, em particular capitães e comandantes de maior visão, de que deveriam voltar a ter como modelo a Royal Navy, ao invés da Marinha dos Estados Unidos". Para o oficial, os brasileiros se ressentiam dos métodos perdulários da Marinha norte-americana e mostravam-se suscetíveis diante da arrogância dos americanos que pareciam propensos a ditar os rumos da Ma-

49 "From Rio de Janeiro do Foreign Office", January I5 I954 e "From Foreign Office to Rio de Janeiro", January I5, I954. FO 37I-I08849.

50 "From Rio de Janeiro do Foreign Office", February 9, I954. FO 37I-I08849.

5I "Admiralty to Foreign Office", 25th February, I954. Em março daquele ano, o Almirantado, fazendo a ressalva de que deveria ser ouvido na escolha, listou os estaleiros no Reino Unido com experiência em construção de porta-aviões, que poderiam finalizar o Leviathan: Harland \& Wolff (Belfast), Vickers Armstrong (tanto em Barrow como no Tyne), Fairfield, Swan Hunter \& Wigham, Carmell Laird, John Brown, Alex Stephens \& Sons e Hawthorne Leslie. Ver "Foreign Office to Naval Attaché", I5th March, I954. FO 37I-I08849.

52 Ludolf Waldmann Júnior, op. cit., p.ııo. 
rinha brasileira. No entanto, ele admitia que qualquer mudança na situação vigente só poderia ser gradual e dependeria de início da redução do tamanho da missão naval dos EUA no Brasil.53

As tensões anglo-americanas reapareceram em ig63, quando o adido naval britânico no Rio de Janeiro, recebeu pedido da firma Shorts, de Belfast, que havia sido contatada pela Marinha brasileira, interessada em saber se o míssil Seacat poderia ser instalado nos contratorpedeiros cedidos pelos EUA. Consultado pelo Foreign Office, em maio, o Almirantado respondeu que "em geral, não é nossa política promover ativamente a venda de mísseis a países latino-americanos", mas "no que tange ao SEACAT para o Brasil, seria difícil recusar um pedido direto de venda se uma encomenda firme for feita". Sugeria-se que a informação fosse fornecida, sem maior compromisso, com o alerta de que alguma consideração deveria ser dada às "suscetibilidades dos EUA quanto a esse tema", uma vez que "as últimas declarações deles indicam que se opõem à exportação de armamento sofisticado a países latino-americanos”. O documento concluía com dúvidas sobre se o Brasil estava em condições de comprar os mísseis, dada a instabilidade política e econômica do país.

Em setembro, Shorts Brothers avisou as autoridades que recebera solicitação urgente do Brasil para apresentar proposta de venda dos Seacats. No mês seguinte, o próprio embaixador Fry argumentou que o negócio seria difícil de recusar, dados contatos semelhantes com Chile e Argentina, mas a situação interna do Brasil, "que alguns acreditam estar à beira de uma guerra civil”, poderia ser um obstáculo. O diplomata lembrava que o armamento em questão era basicamente defensivo e que os americanos não iriam gostar, mas tampouco o governo britânico gostara quando eles venderam aviões aos australianos. A 23 de outubro, a embaixada informava que um grupo de oficiais brasileiros visitaria a firma de Belfast e pedia uma posição clara de Londres sobre a venda. A resposta do Foreign Office veio uma semana depois:

No momento, não podemos ir além da fórmula atual de que Shorts pode apresentar proposta, sujeita a aprovação posterior do Governo do Reino Unido. Os americanos ainda são da opinião de que o Seacat contém know-how americano e que não podemos fornecê-lo a uma terceira potência sem sua permissão com base em argumentos de segurança. Embora estejamos contornando sua objeção no caso do Chile, os americanos não cederam

53 O relatório é assinado pelo capitão J.C.Cockburn. Ao contrário dos elogios feitos pelo adido anterior ao ministro da Marinha de Vargas, Renato de Almeida Guillobel, Cockburn o deprecia, elogiando o novo ministro, almirante Edmundo Jordão Amorim do Valle, nomeado por Café Filho. Ver "Naval Attaché, British Embassy, Rio de Janeiro, to British Ambassador", December 23, I954, FO 37I-I08850. O posto de captain na Marinha britânica equivale ao nosso capitão-de-mar-e-guerra. 
ainda.

O despacho concluía com a constatação de que, se um pedido firme do Brasil fosse apresentado, seria necessário consultar os americanos e, "se a reação fosse negativa, tomar uma decisão sobre se podemos ignorar as objeções americanas". ${ }^{4}$ Com o advento do golpe militar no Brasil, o negócio foi adiado. Enfim, o país diminui suas ambições originais de comprar três estações de mísseis Seacats, a serem instaladas no Minas Gerais e comprou apenas uma unidade, que foi instalada, em i966, no contratorpedeiro Mariz e Barros. ${ }^{55}$

Em setembro de i965, o Arms Working Party, órgão interministerial que supervisionava vendas de armamentos no governo britânico, discutiu a informação do adido naval no Rio de Janeiro de que a Marinha brasileira estaria interessada em adquirir I2 fragatas antissubmarino. Para o adido, o Brasil construiria os cascos e compraria motores e equipamento no Reino Unido. Na ocasião, o AWP discutiu as objeções do Tesouro, com base na situação econômica do Brasil e o parecer favorável do Foreign Office, segundo o qual se o Reino Unido não vendesse ao Brasil, outro país o faria e a Marinha britânica estava interessada na venda de navios a nosso país. ${ }^{56}$ A 29 de setembro, a embaixada britânica comunicou a Londres que um representante da Yarrow fizera no Rio de Janeiro uma apresentação de sua fragata à Comissão de Construção Naval da Marinha brasileira. No encontro, os brasileiros teriam confirmado seu interesse em I2 fragatas anti-submarino e sugerido à firma inglesa que apresentasse uma firme proposta de venda. Segundo essa fonte, os oficiais da Marinha brasileira estavam interessados em construir um primeiro navio no Reino Unido e os restantes no país e mencionaram os estaleiros Mauá, Verolme, Ishikavajima e o próprio Arsenal da Marinha. O representante do estaleiro inglês teria visitado essas firmas. ${ }^{57} \mathrm{O}$ assunto voltou ao AWP no final do mês e ficou resolvido que "a Marinha deveria continuar a negociação com os brasileiros e relatar os progressos ao AWP antes de assumir compromissos mais firmes". ${ }^{8}$

54 Para os despachos referidos neste parágrafo ver FO 37I-I67927, Supply of arms to Brazilian Navy, i963.

55 Ludolf Waldmann Júnior, op. cit., p.r27.

56 "Extract from the minutes of Arms Working Party Meeting of 2-9-65", FO 37I-I79273, Construction of Yarrow Frigates in Brazil.

57 "British Embassy to Foreign Office”, 29 September, I965, FO 37I-I79273.

58 "Extract from minutes of Arms Working Party meeting of 28/9/65", FO 37I-I79273. 


\section{Os britânicos e a venda das fragatas}

Foram necessários quatro anos para que surgissem indícios de que os contatos laboriosamente mantidos depois da Segunda Guerra estavam prestes a dar frutos mais concretos. Em I970, ao introduzir seu relatório anual referente a I969, o adido de Defesa britânico no país, depois de constatar que a presença dos Estados Unidos "tem determinado a escolha brasileira em organização e equipamento de suas Forças Armadas", anunciava: "Há agora sinais de que os brasileiros desejam olhar para outros lugares".59 Para o oficial, dadas as limitações da tecnologia nacional, as Forças Armadas estariam se libertando da camisa-de-força americana. Exemplo disso, no plano naval, seriam as encomendas de dois submarinos da classe Oberon, construídos pela Vickers em Barrow-in-Furness, batizados aqui Humaitá e Tonelero. Mais adiante no mesmo documento, afirmava-se que as relações com a Marinha americana seriam "no geral, boas, mas há sinais de crescente impaciência com sua condescendência paternal". As relações com a Marinha britânica eram vistas como "muito cordiais".

Contudo, o mais importante era a seleção de fragatas a partir de exigências próprias, que, esperava o adido, a indústria britânica seria capaz de atender. Na parte do relatório dedicada à Marinha de Guerra brasileira, o adido anotava: "Espera-se que durante os anos setenta cerca de $50 \%$ da esquadra atual serão sucateados e 56 novos navios devem ser comissionados" e descrevia o começo das aquisições previstas no Programa Decenal ig67-77, apontando a encomenda de dois caça-minas Schutze e o início da construção de seis navios-patrulha no Arsenal da Marinha do Rio, além dos rumores de modernização - com nova eletrônica e possivelmente com mísseis - do porta-aviões Minas Gerais e dos cruzadores Tamandaré e Barroso. No corpo do relatório, o mesmo oficial reafirmava "a perspectiva do Reino Unido vender

59 "Report on Brazil Armed Forces", FCO 7-I5I2, I969. Mais adiante, ele complementava: “As forças continuam a se voltar para os Estados Unidos e, é de suspeitar, a irritar-se com eles". Do lado americano, no começo de i968, ofício enviado ao Secretário de Estado dos EUA pelo encarregado da área latino-americana sugere que aquele comunique ao embaixador brasileiro, Vasco Leitão da Cunha "os difíceis problemas que estamos enfrentando com o Congresso devido à aquisição de certos tipos de equipamento militar pelo Brasil e outros países no Hemisfério", ao mesmo tempo que afirma: "Estamos esperançosos de que poderemos ter uma determinação favorável logo, a qual permitirá a cooperação com o Brasil na construção de dois destroieres da classe Bronstein”. No mesmo texto, fica claro que a preocupação americana era a compra de jatos brasileiros em outros países, dadas as dificuldades para adquirir os F-5 americanos, sugerindo-se ao Secretário que deixe claro ao embaixador que "o conjunto de nosso programa de ajuda externa será seriamente afetado pela decisão brasileira”. Ver ARA Covey T. Oliver to The Secretary, "Briefing Memorandum”, March 22, I968, também cedido ao autor por Carlos Fico. 
o projeto de fragata”. E previa: “A primeira da classe deverá ser construída no R.U. e as restantes seriam construídas no Brasil, possivelmente com assistência externa". ${ }^{60}$

O relatório também afirmava que a decisão sobre as fragatas fora atrasada pelo afastamento do presidente Costa e Silva, em fins de agosto de I969 (devido a um derrame cerebral). Com a posse do general Médici, havia sinais de que o novo ministro da Marinha, almirante Adalberto de Barros Nunes tinha urgência em resolver o problema. No entanto, ele reconhecia que a escolha era complexa, por envolver os termos financeiros oferecidos pelas nações fornecedoras, no caso o Reino Unido, os Estados Unidos e a Alemanha. ${ }^{6 \text { I }}$

$\mathrm{Na}$ avaliação britânica, a Marinha estava dividida entre duas "escolas de pensamento", assim apresentadas: "Os conservadores favorecem a seleção de um desenho convencional bem testado e os mais realistas, a de um projeto moderno, com uma expectativa de vida útil razoavelmente longa". ${ }^{62}$ Para o oficial britânico, não havia na Marinha divisões políticas significativas, resumindo-se as tensões internas a conflitos eventuais de personalidades. ${ }^{63}$

Em meados de I970, na etapa de ajustes finais dos termos financeiros, ocorre intensa troca de telegramas entre a embaixada e vários departamentos do governo britânico (além do Foreign and Commonwealth Office, o Ministry of Defense e o Export Credits Guarantee Departament, Treasury, que enviou um representante ao Rio) com foco em questões como o aumento no teto estabelecido para exportações britânicas a um país específico, a inclusão dos custos das fragatas a serem construídas no Brasil no conjunto do financiamento, a inclusão no financiamento dos mísseis australianos Ikara, bem como o período total do pagamento por parte do Brasil. Foram negociações tripartites, envolvendo o ECGD, o estaleiro Vospers, e os ministério das Finanças e da Marinha no Brasil, esta representada pelo almirante Alcântara (Diretor-geral

60 FCO 7-I5I2.

6і Na lista dos finalistas, estariam as Bronstein, Leander, Köln, Mackenzie, Type 21 e Yarrow Mark 8. Para uma descrição detalhada do projeto básico dessa fragata (Mark 1), ver a matéria provavelmente paga "A fragata Yarrow", publicada na Revista Marítima Brasileira, 2. Trimestre I970, pp.I26-I33.

62 Na documentação diplomática trocada entre o Rio e Londres, a partir de julho de I970, referente aos acertos financeiros finais para a venda das fragatas, um dos argumentos utilizados para convencer as autoridades financeiras Londrinas sobre a necessidade de flexibilizar as negociações foi a presença de uma suposta "facção antibritânica" na Marinha brasileira, que preferiria "comprar de países cuja indústria está firmemente estabelecida aqui". Ver "Britnavatt, Rio de Janeiro to MOD”, 3I July I970, Naval sales from United Kingdom, FCO 7-I5II.

63 Em sua avaliação, a força naval brasileira tinha reconhecidamente preparo superior ao das outras marinhas latino-americanas, mas o material flutuante obsoleto prejudicava seu desempenho. A Marinha era considerada como a mais eficiente das três forças armadas brasileira. 
de Material da Marinha). Na correspondência, a embaixada insiste que o negócio das fragatas é o maior feito pelo Reino Unido nos últimos anos e que o Brasil tem condições econômico-financeiras crescentemente sólidas. Segundo fonte brasileira este montou, ao final, em 98.650.000 libras esterlinas e o prazo de entrega da quarta fragata inglesa seria de 35I semanas, a contar de 8 de janeiro de I97I. $^{64}$

Fica claro na documentação que a ideia de construir duas fragatas no Brasil originou-se na falta de interesse da Vosper em comprometer seu estaleiro com a construção de seis navios para um só cliente, bem como na impossibilidade de outro estaleiro inglês (Vickers, principalmente, cujo representante no Rio participou também de algumas das conversações) assumir a encomenda parcial. Ainda assim, ressurgem aqui alusões a posições divergentes no interior da Marinha. Em telegrama datado do início de agosto, o embaixador Hunt relata a Londres os resultados das negociações acima, afirmando que, diante da decisão ministerial pela fórmula $4+2$, surgiram duas correntes de opinião na força naval: por um lado, almirantes mais antigos denotaram "forte preferência" pela construção de todas as seis fragatas no Reino Unido; por outro, havia "um pequeno grupo de opinião, basicamente composto por jovens oficiais, que favorecem a construção local por razões nacionalistas". O ofício concluía: "Na ausência de qualquer oferta para construir os navios número 5 e 6 no Reino Unido, a Marinha recorreu à construção local, como única solução que permitiria uma submissão única do ministro da Marinha no futuro próximo". ${ }^{65}$

Outro tema importante tratado no mesmo telegrama é o da necessidade do MOD agir com mais decisão junto à firma Vickers, para que esta se manifestasse o mais rápido possível sobre seu interesse em fazer as duas fragatas, para encerrar essa questão. Estava claro, nessa altura, que o estaleiro Vosper só estava preocupado com as quatro fragatas de sua responsabilidade, não lhe importando se as outras duas seriam feitas aqui ou no Reino Unido. Os interesses mais amplos do governo britânico e os alvos mais imediatos dos estaleiros ficam aqui bastante claros.

Com efeito, a diplomacia britânica tinha nítido interesse em ver os seis navios feitos no Reino Unido. Para o embaixador, a decisão do ministro da Marinha de fazer dois navios no Rio de Janeiro representava "uma posição menos satisfatória para nós que o fornecimento total, preferível tanto do

64 Fernando Moraes Baptista da Costa, "Fragatas classe Niterói - 25 anos depois”, Revista Marítima Brasileira, I. Trimestre de I997:III-I37, p.II2.

65 Telegrama de Sir David Hunt ao ECGD, 4 de agosto de I970 em FCO 7-I5II. 
ponto de vista militar como comercial" ${ }^{66}$ Contudo, uma vez tomada a decisão de fazer duas fragatas no Rio, procura-se convencer os "especialistas financeiros" em Londres a flexibilizar as negociações, descrevendo as divergências no interior do governo brasileiro, dividido, segundo ele, entre a clara opção da Marinha pelo Reino Unido e os argumentos da área econômica brasileira, principalmente o ministro das Finanças, Delfim Netto, sobre a conveniência de considerar outros fornecedores. A possibilidade de reabertura da licitação constituiu argumento forte do embaixador para convencer as autoridades comerciais a ceder em pontos menores. Partidário vigoroso da diplomacia como veículo preferencial dos interesses comerciais de seu país, Sir David Hunt deixava clara sua posição sobre a importância de ceder em detalhes para fechar o negócio, "particularmente quando consideramos que isso seria uma maciça consolidação de engenharia e técnica militar da cabeça de ponte comercial que apenas estabelecemos, depois de um longo período fora do mercado nessas áreas". ${ }^{67}$ No mesmo dia, o diplomata escrevia ao Foreign Office:

O negócio das fragatas não é apenas importante por si só, devido a sua dimensão, mas, em minha visão, constitui o maior fator individual na mudança da decisão de se triunfaremos em reconquistar nossa antiga posição no Brasil. A decisão da Marinha de vir até nós para seu reequipamento tem tremendas consequências econômicas e políticas. ${ }^{68}$

Referindo-se às boas condições das relações anglo-brasileiras no começo dos anos 1970, ele afirmaria algum tempo depois: “Tudo isso me agradava muito porque, já há alguns anos, estava convencido de que a economia era realmente mais importante que a política". E completava: "Como eu costumava dizer a minha equipe: ‘É o comércio que paga nossos salários”. ${ }^{69}$ Logo em seguida, o departamento do Tesouro britânico deu sinal verde para o financiamento, com prazo de pagamento de oito anos, "contanto que o contrato seja assinado imediatamente". No mesmo dia, o embaixador no Rio referia-se ao desejo expressado pelo almirante Coelho de Sousa, nomeado chefe da comissão de aquisição das fragatas no Reino Unido, de que, antes da assinatura do Memorando de Entendimento, o MOD assessorasse a Marinha nas suas

66 Idem em FCO 7-I5II.

67 Idem, em FCO 7-I5II.

68 Ver telegrama de 6 de agosto em FCO 7-I5II. Vinte dias depois, comemorando o fechamento do negócio, Sir David Hunt escrevia ao FCO: "Devem haver muito mais vendas navais no porvir, além do negócio das inevitáveis peças de reposição". Ver telegrama de 25 de agosto de I970 em idem.

69 Ver Sir David Hunt, op. cit., p.3II. 
relações subsequentes com o estaleiro Vosper, serviço que seria pago pelo Brasil. ${ }^{\circ}$

A partir daí, a embaixada passa a se preocupar em convencer Londres sobre a necessidade de atender as expectativas nacionais quanto à pompa $\mathrm{e}$ circunstância da assinatura do contrato. "A marinha brasileira atribui significado histórico e emocional considerável a esta transação, que é a primeira fase importante da modernização de sua esquadra”, dizia Hunt. E avisava: “Eu apoio a atitude deles: a decisão de comprar na GB não lhes foi fácil, tendo em vista seu relacionamento estreito com o Estados Unidos". Com base nisso, o embaixador sugeria "que a assinatura formal do acordo tenha lugar nas circunstâncias mais impressionantes que se possa arranjar”, aludindo mesmo à possibilidade de recepção pela Rainha..$^{71}$

Londres, contudo, duvidava que "o envolvimento da família real fosse praticável”, dadas dificuldades de agenda (seria período de férias da monarca) e o próprio nível das autoridades brasileiras. A 2I de agosto, o Ministério da Defesa apoiou a posição de seus colegas no FCO. No final, o contrato foi assinado a 29 de setembro, na Admiralty House, em Londres, com a presença do ministro Delfim Netto e do ministro da Defesa britânico, além do alto comando da Marinha daquele país.

\section{Armamentos e política externa}

No balanço que enviou logo a seguir a Londres, o embaixador Hunt avaliou em termos triunfais a dimensão e as perspectivas do negócio. Aludindo à venda dos submarinos, um ano antes, ele dizia: "Essas duas transações, além de contribuir maciçamente para nossas crescentes exportações para o Brasil, devem também, se propriamente administradas, estabelecer uma influência técnica britânica dominante na Marinha brasileira para os próximos vinte anos". Na sequência, ele descrevia a trajetória histórica da opção brasileira pelos navios britânicos, mencionando as dificuldades colocadas pelos americanos à opção mais óbvia do Brasil em recorrer a sua ajuda, para obter a fragata da classe Bronstein. Aludia também ao sucesso da viagem oficial da rainha Elizabeth ao Brasil, em novembro de ig68, acompanhada por duas fragatas da Royal Navy, da classse Leander, evento complementado no ano

\footnotetext{
70 Ver telegrama de 6 de agosto em FCO 7-15ı. Totalizando mais de ıoo milhões de libras os pagamentos seriam realizados semestralmente, em dezesseis parcelas, no equivalente a $80 \%$ do preço total, iniciando em I-4-76 e terminando em I-Io-83. Ver telegrama de 26 de agosto de I970 em FCO 7-I5II.
}

7I Hunt ao Foreign Office, 5 de outubro de I970 em FCO 7-I5II. 
seguinte pela visita de um esquadrão britânico, que incluiu dois submarinos da classe Oberon, a mesma dos que seriam construídos para nossa Marinha.

Segundo o embaixador, as negociações posteriores para a compra de submarinos dessa classe incluíram, por parte do encarregado de negócios da embaixada britânica, a proposta de vinculação da assinatura do contrato dos submarinos "à promessa de um financiamento vantajoso para fragatas e componentes fornecidos pela Grã-Bretanha, incluindo custos creditícios locais para alguma construção brasileira". A proposta teria sido formalizada junto ao Ministério das Finanças brasileiro a I8 de março de I969 "em uma carta entregue em mãos ao almirante Adalberto Nunes, então chefe do Estado-Maior da Armada". $7^{2}$

O balanço era marcado pela avaliação ufanista do embaixador sobre as perspectivas abertas pela compra das fragatas pela Marinha brasileira. Segundo ele: "A decisão de adotar projetos britânicos como padrão para as unidades maiores na esquadra brasileira envolve uma mudança decisiva de padrões e equipamentos americanos para britânicos, não apenas nos navios em si, mas no armamento, serviços de apoio e sistemas de treinamento", o que poderia anunciar "uma proliferação de oportunidades de exportação britânicas em muitos campos além dos cobertos pelos presentes contratos". "Não menos importante", continuava, "será a renovação dos contratos estreitos entre as duas marinhas", o que já podia ser visto no processo de construção dos submarinos. "Se manejarmos bem essas oportunidades - arriscava - a próxima geração de oficiais navais brasileiros deve falar inglês com sotaque de Southampton ou Barrow, tal como, em quase todos os casos, os atuais tenentes e comandantes falam (quando falam) com o sotaque do Brooklyn e de Newport News". 73

Tais esperanças não se limitavam à esfera naval. Para Sir David, "esses contatos podem assumir crescente importância política”, nos quadros da tendência brasileira em direção de uma "Estratégia do Hemisfério Sul”, que implicaria colaboração entre Brasil, Argentina e África do Sul, podendo se

72 Ver idem, p.5. Convém salientar que essa parte das negociações constitui um dado novo, não mencionado até hoje na história oficial da Marinha brasileira. No mesmo documento, Sir David Hunt menciona a história de que a opção alemã foi prejudicada quando da visita de navios alemães ao Brasil. Na ocasião, ao ser perguntado por oficiais brasileiros como avaliava sua fragata, o capitão da marinha alemã teria se referido depreciativamente às fragatas Köln . Ver idem, p. 7 .

73 Como de hábito na documentação diplomática britânica, o embaixador refere-se com ironia às limitações do país em que está sediado. Para ele, a firma Vospers tinha que ser elogiada pela paciência com que negociou com os suscetíveis oficiais brasileiros, o que augurava sucesso "para a compreensão que deverão trazer à formidável tarefa de ensinar os brasileiros a construir navios de guerra". 
estender depois a outras nações como a Austrália. Na visão do diplomata, embora registrasse que tal estratégia não tinha muito sentido em termos de defesa, ela interessaria aos britânicos, que poderiam no futuro fornecer fragatas a esses países. O representante britânico concluía sua entusiasmada avaliação com recomendações de tratamento especial às relações anglo-brasileiras. Para tanto, seria necessário que seu país imitasse em alguns aspectos o modelo americano de oferecimento de vantagens múltiplas em negociações de equipamento militar.74

Com efeito, nos anos seguintes, a relação entre as duas marinhas foi vista como um dos aspectos cruciais das relações entre britânicos e brasileiros. Assim, escrevendo ao embaixador de Sua Majestade no Brasil, para agradecer seu relatório anual referente ao ano de 1974, o chefe do Departamento Latino-Americano do Foreign and Commonwealth Office, Hugh Carless, lembrava:

A contínua conexão e cooperação entre as marinhas da Grã-Bretanha e do Brasil constitui um ponto importante nas relações anglo-brasileiras. Gostaríamos, portanto, de receber de vocês no devido tempo um sumário de suas visões sobre o papel e futuro da Marinha brasileira e as possibilidades abertas para nós para manter e possivelmente aprimorar as boas relações que existem atualmente no setor naval.75

Dessa forma, a documentação diplomática não deixa dúvidas sobre a importância do negócio das fragatas para o governo britânico, derivada em grande medida da própria relevância da indústria bélica naval no conjunto da economia daquele país. Como apontou o holandês Sami Faltas, em sua análise do mercado de armamentos europeu no período entre i960 e i980, ao contrário dos Estados Unidos e da França, onde prepondera a indústria aeroespacial, "na Grã-Bretanha e na Holanda, e em menor grau na Itália e na RFA, a indústria naval pode ser um enfoque mais útil à indústria de armamentos como um todo. Sua importância relativa é maior nesses países e ela é comercial e voltada para fora". $7^{6}$ Para ele, até I960, apenas a Grã-Bretanha tinha capacidade de produzir seus próprios navios, traço que mudou significativamente nas décadas seguintes, com o desenvolvimento da indústria naval em vários países da Europa. Nesse quadro, a competitividade britânica

74 Do lado brasileiro, a negociação terminou com a concessão, a 26 de novembro, da Ordem do Mérito Naval a Ronald Dickinson, que representou o governo britânico nas tratativas com os brasileiros.

75 Ver FCO 7-276I.

76 Op. cit., p. 18 . 
comparativamente diminuiu. Ao mesmo tempo, registrou-se desde finais dos anos I960 uma nítida internacionalização dos mercados.77

Mas o mais importante a notar é que a venda de navios de guerra constitui uma decisão de Estado, onde política e economia estão intimamente ligadas. Como lembra Faltas:

Considerações de política externa e outros fatores políticos afetam cada decisão específica de importar ou exportar navios. Compradores e vendedores podem utilizar as negociações de vendas de armas para reforçar ou desafiar esferas de influências existentes. Negociações de vendas de armas estão habitualmente vinculadas a outros tipos de negociações de relações político-militares e econômicas. ${ }^{78}$

O mesmo autor destaca que as negociações de armamentos são um caminho de duas mãos:

Os principais estados fornecedores de armas utilizam suas transferências de armamentos para aumentar sua influência sobre outros estados, tanto dentro como fora de sua esfera de influência. Por sua parte, os importadores de armamentos utilizam as negociações sobre fornecimento de armas, seja para conseguir ou ampliar o apoio de uma potência para suas políticas, seja para se tornarem menos dependentes de um único fornecedor. Adquirir equipamento militar de vários fornecedores torna um país menos suscetível à pressão de uma única fonte.79

Nesse esforço, evidentemente, esses países não estavam à procura de submarinos nucleares ou grandes navios de superfície. As vendas a que nos referimos aqui dizem respeito basicamente a navios menores: submarinos convencionais, destroieres, fragatas, corvetas, equipamento de ataque rápido, caça-minas, barcos anfíbios e de patrulha costeira, etc. ${ }^{80}$ É bom notar, porém, que as compras de navios de escolta ainda eram divididas meio a meio, entre material usado e material novo, ainda no final dos anos $1970 .{ }^{81}$ No lado com-

77 Idem, p.30-3I e p.52 e segs.

78 Idem, p.58.

79 Idem, p.59.

80 O mesmo autor descreve assim a parcela de mercado desses tipos de navios no período I960-I980: Io \% para submarinos convencionais; $28 \%$ para navios de escolta; e 6i\% para barcos rápidos. Op. cit., p.66.

8I "No campo dos destroieres, fragatas e corvetas, encontramos pouca evidência de mudança nos modos de aquisição durante nosso período" (I960-I980). E continua: "É interessante notar que as importações de navios usados no final dos anos setenta ainda era responsável por 
prador, havia menos países capazes de adquirir navios de escolta que barcos de ataque menores. No lado fornecedor, no começo dos anos 1970 começa a se consolidar a tendência de concentração da indústria de navios de guerra novos na Europa ocidental, onde se origina a tecnologia contida nesses equipamentos. Ao mesmo tempo, as exportações são o esteio da indústria naval militar europeia. Segundo o autor que vimos citando, "sem a exportação de navios de guerra, a maior parte das indústrias navais não poderia continuar na sua presente capacidade e várias delas não poderiam sobreviver simplesmente". ${ }^{82}$ Outra tendência importante no lado fornecedor no período que examinamos é a da "transferência" de tecnologia, mais exatamente a da fabricação de alguns navios da mesma classe em estaleiros localizados nos países compradores:

O período analisado presenciou um aumento no número de transferências de tecnologia de construção de navios de guerra de um país para outro, um aumento no número de países exportando tal know-how, e um aumento no número de países importadores. Um mercado internacional por tecnologia de construção de navios de guerra para emergir, dizia Faltas referindo-se aos anos 1970.83

Nas três primeiras décadas do pós-guerra cresceu significativamente o número de países, principalmente do Terceiro Mundo, construtores de navios dos tipos mencionados acima (de 9 para 37). Por sua vez, a participação dos fornecedores europeus nesse mercado de "transferência" de tecnologia de navios de guerra, subiria de io para 70 por cento no decorrer dessa década, com destaque para a Alemanha ocidental cuja parcela subiu de nada para 40 por cento, com produção principalmente de submarinos e navios de ataque rápidos. ${ }^{84}$ Algumas especificidades marcam a indústria naval alemã: a longa tradição na construção de submarinos e outros navios; a independência em relação ao Estado e, em menor escala, as restrições à exportação de equipamento militar. De todo modo, um fator fundamental para o sucesso alemão

metade da demanda total por navios de escolta para o mercado externo, enquanto a produção doméstica e as novas importações conservavam uma parcela comparativamente pequena do mercado". Op. cit., p.67.

82 Idem, p.69.

83 Idem, p.73.

84 Do lado comprador, enquanto nos anos I950 países como o Brasil não receberam praticamente nenhuma "transferência" de tecnologia, nos final dos anos I970, pelo menos metade desses negócios ia para países então sem indústria naval avançada. Entre eles, destacavam-se Argentina, Brasil, Colômbia, Índia, Irlanda, Malásia, Peru, Portugal, Singapura, África do Sul, Coréia do Sul e Turquia. Idem, p.75-77 e nota I4, p.95.. 
foi a disposição de sua indústria naval de satisfazer o desejo dos países compradores, como Argentina e Turquia, de fabricar localmente seus submarinos. ${ }^{85}$ No final da década, a importância desse tipo de negócio crescera a ponto de marinha europeias terem mudado seu próprio equipamento com um olho em sua atratividade para os mercadores compradores externos. ${ }^{86} \mathrm{Um}$ outro tema a ser analisado seria o da importância cada vez maior dos equipamentos na construção naval. A Europa foi capaz também de manter hegemonia nessa área, mas nesse caso a diferença entre os armamentos e outros equipamentos instalados em seus navios e os instalados nos barcos vendidos a marinhas estrangeiras colocou problemas de escala na produção naval europeia, que não poderemos examinar aqui. ${ }^{87}$

Já os britânicos estavam particularmente bem posicionados para atender à demanda de marinhas como a do Brasil por fragatas de tecnologia avançada, pois sua própria Marinha demandou esse tipo de navios nos anos anteriores. Com efeito, no quadro da busca da OTAN por se contrapor à Marinha soviética, para a indústria naval britânica foi especialmente relevante a construção de navios de escolta. ${ }^{88}$ Alguns autores atribuem essa característica à situação econômica do pós-guerra - o que levou esse país a concentrar-se em alternativas mais em conta -, bem como a razões de estratégia naval: a crença prevalecente, então, na supremacia do poder aéreo, o que levava à ênfase nos porta-aviões, que por sua vez necessitavam de navios de escolta. ${ }^{89}$ De todo modo, a maior parte dos navios produzidos pelos estaleiros britânicos nesse período foi de fragatas. Foi esse o contexto em que os britânicos desenvolveram as já mencionadas fragatas Leander, feitas entre I96I e I97I e consideradas um marco nesse tipo de navios. $9^{\circ}$ Daí o interesse precoce do governo

85 Idem, p.79.

86 Foi o caso britânico dos submarino Type 2400 e das fragatas Type 23. Idem, p.83 e nota 29, p. 96

87 Faltas, op. cit., p.I6o.

88 Como lembrou Eric Osborne: "A potência naval com a maior produção foi a Grã-Bretanha. Nesse período (I955-1967), destróires e fragatas de menores dimensões passaram a representar a maioria da frota de superfície britânica". Ver Destroyers: an illustrated history of their impact, Santa Barbara/Denver/Oxford, ABC Clio, 2005, p.I39.

89 Para outro autor, "certo ou errado, o principal objetivo da doutrina naval da OTAN parecia ser impedir uma reencenação da Batalha do Atlântico, com os submarinos soviéticos tomando o lugar dos U-boats alemães". Ver Sami Faltas, op. cit., p.28.

90 As Leander constituíram uma evolução - no desenho e nas instalações de radar e controle aéreo - das fragatas de uso geral britânicas conhecidas como Type 12, desenvolvidas nos anos I950. O projeto das fragatas Type 12, "em suas várias encarnações forneceu a espinha dorsal da Royal Navy desde cerca de I965 a I985". Ver Eric Grove, "Major surface combatants", in Robert Gardiner (org.), Navies in the nuclear age: warships since 1945, London, Conway Maritime Press, I993, p. 50-5I. Osborne afirma que alguns especialistas consideram as fragatas dessa classe 
britânico em fortalecer seu parque industrial naval com a venda de fragatas a países como o Brasil. O fato de pertencer à OTAN, evidentemente, não significava que a Grã-Bretanha não competisse ativamente com seus aliados na busca de mercados para seus navios. ${ }^{9 \mathrm{I}}$ Enfim, as compras brasileiras talvez tenham contribuído para o breve pico de exportações militares navais britânicas no começo dos anos I970.

Em I965, o chamado relatório Geddes, produzido para o governo britânico, recomendou que a indústria naval doméstica se concentrasse em um número pequeno de estaleiros especializados, três no caso dos barcos de superfície. Nos anos seguintes, a Marinha britânica consolidou uma tendência a fabricar navios "líderes" (lead, primeiros de uma classe) nesses estaleiros e navios "subsequentes" (follow-on) em um número ligeiramente maior de firmas. Na análise de Faltas,

para os fabricantes especialistas de navios de guerra - Vickers, Vosper Thornycroft, Yarrow e Brooke Marine - a especialização significava uma dependência virtualmente completa do governo para a provisão de encomendas da Royal Navy e para a ajuda em assegurar contratos de exportação de navios de guerra..$^{2}$

Ele defende que nos anos I970 era nítida a militarização de alguns dos maiores e mais modernos estaleiros, garantida por encomendas nacionais e internacionais. ${ }^{93}$ Entre as empresas britânicas, no começo dos anos I970, a Vosper era a única especializada exclusivamente em navios médios e, na lista dos especialistas, era mais a nova. ${ }^{94}$ Foi crucial, assim, para essa firma o projeto das fragatas classe Amazon, desenvolvido em cooperação com

“entre as melhores de seu tipo construídas na era dos mísseis", op. cit., p. 252. Foram lançadas ao mar vinte e seis navios, mais catorze para exportação (seis foram feitos na Holanda e seis na Índia). Medindo 372 pés, portavam dois canhões de 4.5 polegadas, quatro mísseis SAM Seacat, um MK 20 Limbo, além de um helicóptero Wasp. Deslocam 2350 toneladas. Algumas unidades ainda estavam em uso em marinhas menores no começo do século XXI.

9I Ver Faltas, op. cit., p.27.

92 Ver tabela 27 em op. cit, p.204: “Especialização na construção britânica de navios de guerra".

93 Entre meados dos anos I950 e meados dos anos I970, a porcentagem de construção naval no conjunto da produção dos estaleiros britânicos passou de i6\% para 42\%. Ver Faltas, cit., p. 205 .

94 "E evidentemente que, por ser a mais nova, a Vosper tinha uma disputa muito grande com os outros estaleiros. Os encouraçados eram Vickers, Saldanha, que era nosso navio-escola, Vickers. A Marinha argentina comprava lá em cima também, na Escócia. Então, a Vosper fez um esforço realmente grande - e talvez daí advenham algumas vantagens para o Brasil - para pegar contratos". Depoimento citado de Fernando Costa ao autor. 
o Ministério da Defesa britânico. ${ }^{95}$ Desse projeto sairiam os modelos $M K-10$ e $M K-11$, dos quais uma das versões acabou gerando a nossa classe Niterói. A importância atribuída tanto pela Vosper quanto pelo governo britânico à venda das fragatas ao Brasil tem que ser vista nesse quadro mais amplo.

Em maio de I976, o presidente Geisel realizou sua visita de Estado ao Reino Unido. Naquela altura, chegou ao ápice a oposição doméstica, inclusive por parte do próprio Partido Trabalhista no poder, à aproximação do governo britânico com a ditadura brasileira. Sem a compreensão da história das relações navais anglo-brasileiras, fica difícil entender parte fundamental das relações entre os dois países nos anos i970. No final da década, eram amplas e variadas as compras militares brasileiras na Grã-Bretanha. Nesse quadro, a história das relações entre Brasil e Europa no período da ditadura militar, ganha novos sentidos se for considerado esse aspecto até aqui praticamente ignorado das relações entre democracias e ditadura: as relações militares, com destaque, no caso das relações anglo-brasileiras, para a aproximação armamentista naval entre os dois países nos anos I970.

\section{REFERÊNCIAS}

Bierrenbach, Julio de Sá. I996. 1954-1964: uma década política. Rio de Janeiro: Domínio Público.

Brasil, Mauro. I97I. "Considerações sobre o Plano Diretor da Marinha". Revista Marítima Brasileira 2 Trimestre: II5-I28.

Costa, Fernando Moraes Baptista da. I997. "Fragatas classe Niterói - 25 anos depois”. Revista Marítima Brasileira I. Trimestre: III-I37.

D'araujo, Maria Celina and Celso Castro (orgs.). I997. Ernesto Geisel. Rio de Janeiro: Editora Fundação Getulio Vargas.

Faltas, Sami. 1986. Arms markets and armament policy: the changing structure of naval industries in Western Europe. Dordrecht/Boston/Lancaster: Martinus Nijhohh.

Foster Dulles, John W. I980. President Castello Branco: Brazilian Reformer. Texas: A\&M University Press.

95 Para o depoente citado na nota anterior: "O que veio aqui para ser negociado não foi a fragata Marca-10, foi a fragata Marca-11, que é a classe que os argentinos compraram, a classe da Hercules. Esse era o projeto que a Vosper estava desenvolvendo com o MOD - eu embarquei numa fragata dessas, da classe Amazon, projeto que foi comprado, comissionado e funcionou bastante tempo para a Marinha inglesa. As Marca-11 eram um pouquinho maiores que as Mar$c a-10$. A diferença era mais de conceito, de armamento, etc, mas era um projeto que foi dado pelo MOD à Vosper". Idem. 
Grove, Eric. I993. "Major surface combatants". In Navies in the nuclear age: warships since 1945 edited by Robert Gardine, 50- 51. London: Conway Maritime Press.

Guillobel, Renato de Almeida. I959. Algumas apreciações sobre a administração naval. Rio de Janeiro: Imprensa Naval.

Hunt, David. 2006. Memoirs: military and diplomatic. London: Trigraph.

Lessa, Antonio C. M. 1994. "Brasil, Estados Unidos e Europa Ocidental no contexto do nacional-desenvolvimentismo: estratégias de diversificação de parcerias: I974-I979.” Master's thesis. UNB, Brasília, Brazil.

Martins Filho, João Roberto. 2005. "As políticas militares dos EUA para a América Latina, I947-I989”. Teoria Q2 Pesquisa 46: IOI-I35.

A Marinha brasileira na era dos encouraçados, 1895-1910. 20I0. Rio de Janeiro: FGV.

Moura, Leandro. I994. “From 'automatic alignment to 'difficult pragmatism': shifts in Brazilian foreign policy and their impact on Anglo-Brazilian military contacts, I945-I954". Master's thesis. London School of Economics \& Political Science, London, United Kingdom.

Osborne, Eric. 2005. Destroyers: an illustrated history of their impact. Santa Barbara/Denver/Oxford: ABC Clio.

Pinto, Paulo Lafayette. I974. "A Marinha e a construção de navios de guerra no Brasil". Revista Marítima Brasileira 2 trimestre: 19-44.

Sousa, José Carlos Coelho. 200I. Uma história das fragatas. Rio de Janeiro: Clube Naval Editora.

Souza, Mozart Padilha de. I97I. "O Plano Diretor: realidades e perspectivas da Marinha”. Revista Marítima Brasileira 2. Trimestre: Io8-II4.

Viana Filho, Luís. I975. O governo Castelo Branco. Rio de Janeiro: Biblioteca do Exército e Livraria José Olympio Editora.

Vidigal, Armando Amorim Ferreira. 2002. A evolução do pensamento naval estratégico brasileiro: meados das décadas de 70 até os dias atuais. Rio de Janeiro: Clube Naval.

Waldmann Junior, Ludolf. 2013. "Tecnologia naval e política: o caso da Marinha brasileira na era dos contratorpedeiros, I942-1970". Master's thesis. UFSCar, São Carlos, Brazil. 


\section{RESUMO}

Este artigo tem o propósito de analisar o caso da aquisição das fragatas Vosper pela Marinha brasileira, que aconteceu no começo dos anos 1970. Além de ser um caso ilustrativo de disputas de política internacional, demonstra como interesses econômicos podem definir a política externa das nações. O negócio das fragatas é considerado estratégico para a relação entre o Brasil e o Reino Unido.

\section{PALAVRAS-CHAVE}

Relações Navais; Brasil; Reino Unido; Fragatas Vosper.

Recebido em 2 de julho de 2015. Aprovado em 17 de julho de 2015. 


\section{UMA ANÁLISE COMPARATIVA DO IMBRÓGLIO DO JAPÃO IMPERIAL NA CHINA E DO IMPASSE NORTE-AMERICANO NO IRAQUE PÓS-SADDAM: SIMILARIDADES, LIÇÕES E IMPLICAÇÕES}

\section{Masahiro Matsumura'}

\section{Introdução}

Durante a última década, o hegêmona EUA tem gradualmente apresentado sinais claros de declínio relativo em meio às mudanças na distribuição internacional de poder, particularmente contrastando com a ascensão significativa da China (National Intelligence Council 20I2). Além disso, o hegêmona sofreu déficits fiscais enormes e problemas financeiros consequentes do assim chamado Choque Lehman do outono de 2008 , envolvendo acentuadas vulnerabilidades econômicas estruturais. Mais recentemente, os Estados Unidos têm continuamente enfrentado cortes no orçamento, que inevitavelmente levará a grandes reduções nos gastos com defesa e, então, ao enfraquecimento de sua hegemonia militar (Barno 20II).

Grandes gastos militares com a prolongada guerra contra o terrorismo no Oriente Médio, focada previamente no Iraque e atualmente no Afeganistão, têm agravado consideravelmente a situação das finanças nacionais do EUA, afetando significativamente a economia nacional pós-Lehman. Em retrospectiva, percebe-se que a administração Bush reagiu erroneamente de forma exagerada aos chocantes ataques terroristas de II de setembro de 200I, diretamente nos centros econômico e militar dos EUA, com intervenções mi-

\footnotetext{
I Professor de Política Internacional e de Segurança Nacional da Faculdade de Direito de St. Andrew's University (Momoyama Gakuin Daigaku) em Osaka, no Japão. E-mail: masahiro@ andrew.ac.jp
} 
litares massivas no Afeganistão e depois no Iraque, com o propósito de state-building e democracy-building em ambientes multiétnicos.

A fim de explorar o porquê deste erro estratégico cometido pelos EUA, este estudo fornecerá uma perspectiva alternativa, baseada, em termos gerais, na abordagem ecológico-histórica japonesa do espaço eurasiano e, em particular, na experiência histórica do Japão Imperial no continente Chinês durante os anos de I930 e I940. Mais especificamente, esta perspectiva é relevante igualmente para analisar a política internacional de guerra de contra-insurgência em diferentes regiões geográficas, incluindo não somente o Leste Asiático, mas também o Oriente Médio.

Tradicionalmente, acadêmicos ocidentais e japoneses da área de estudos internacionais não se comunicam bem uns com os outros, especialmente quando analisam a política internacional e diplomacia nos anos I930 e I940, centrados na questão da China. Isto se deve porque o mainstream dos estudiosos japoneses discutiram primeiramente os detalhes da experiência histórica japonesa, sem apresentar boas teorias ou esforços para teorizar sobre suas narrativas. Certamente, a maioria destes estudiosos tiveram sua formação disciplinar centrada primeiramente na história diplomática, e não na ciência política ocidental, em geral, ou nos estudos das relações internacionais, em particular. Contudo, historiadores diplomáticos geralmente possuem ao menos uma estrutura implícita em suas narrativas. Este estudo foi formulado para preencher esta lacuna, dado que a maior parte dos estudiosos japoneses dedicam-se ao discurso intelectual ativo em japonês, no qual são pouco demandadas teorias ou teorização no estilo ocidental.

Mais especificamente, dada a barreira linguística, estudiosos ocidentais, especialmente aqueles dos Estados Unidos, permanecem desinformados sobre os trabalhos japoneses referentes ao imbróglio do Japão Imperial e, em particular, sobre a guerra de contra-insurgência na China de modo que continuamente carecem de referências aos trabalhos japoneses. Entretanto, este estudo argumentará que a perspectiva japonesa é relevante para compreender o impasse dos EUA no Iraque pós-Saddam e a contínua guerra contra o terrorismo no grande Oriente Médio, considerando uma série de fortes paralelos entre os dois casos, apesar da grande distância temporal e espacial que os separam. De fato, conforme analisado abaixo, o governo, os militares e a população dos Estados Unidos caíram em armadilhas muito similares às que martirizaram os equivalentes do Japão Imperial. Este estudo não tem por objetivo defender as transgressões japonesas relacionadas à guerra, embora conjecture que o escopo e a extensão destas foram mais limitados do que geralmente acreditado. Nem procura endossar o lado sombrio das atividades militares dos EUA no Iraque. Ao invés disso, o objetivo é ressaltar o contexto, 
a natureza e as implicações de estar preso em uma guerra de contrainsurgência no mundo em desenvolvimento, tal como a China no passado e o Oriente Médio atualmente, particularmente no Iraque pós-Saddam. A experiência dos Estados Unidos no Vietnam é irrelevante para prescrição de políticas devido a sua natureza central de uma guerra de liberação nacional no contexto da Guerra Fria. Da mesma forma são as experiências dos EUA nas democratizações pós-Segunda Guerra Mundial na Alemanha e Japão ocupados, dado que ambas não requeriam processos de nation-building, mas sim de reativação de tradições democráticas nativas, como demonstradas respectivamente pela República de Weimar e pelo período democrático da Era Taisho.

Certamente, pode causar estranhamento a comparação entre o Leste Asiático antigo e o Oriente Médio atual. Esta impressão é pertinente, dada a clara divisão-do-trabalho entre análises globais e estudos de área no ensino e pesquisa das relações internacionais e de estudos comparativos, assim como devido à suposição de que cada região geográfica possui uma cultura política única e dinâmicas políticas a serem exploradas. A fim de desafiar este entendimento baseado no senso comum, este estudo enfatizará a importância da divisão de categorias de mundo desenvolvido versus mundo em desenvolvimento, em uma tentativa de compreender as dinâmicas da guerra de contra-insurgência, de fenômenos políticos relacionados e de resultados político-militares ao longo de regiões.

A análise a seguir apresentará, em primeiro lugar, uma série de notáveis paralelos entre a experiência passada japonesa e a experiência atual dos EUA. Em segundo lugar, fornecerá uma perspectiva teórica do porquê os dois casos compartilham tais similaridades. Em terceiro lugar, o estudo explorará as implicações desta perspectiva para a política internacional, focando-se no futuro da hegemonia dos EUA.

\section{Notáveis Paralelos}

No dia 2 de Setembro de I945, a Segunda Guerra Mundial acabou com a rendição do Império Japonês às forças Aliadas lideradas pelos EUA. Naquela época, o exército japonês ainda dispunha de mais de um milhão de soldados na China (Jowett I999) além de cerca de oitocentos mil soldados na Manchúria (NIDS I974). De fato, o Japão estava encurralado com a prolongada guerra de contra-insurgência na China possivelmente por I5 anos desde o Incidente da Manchúria em i93I. Concomitantemente, o Japão travou uma guerra interestatal total com os Estados Unidos de I94I a I945, apesar do poder material e militar esmagador dos americanos, que os japoneses não conseguiriam jamais rivalizar. Isto significa que, quando iniciou a guerra con- 
tra os Estados Unidos, o Japão já havia se prejudicado na China e despendido uma grande quantidade de material e recursos humanos.

\section{1) Objetivo Político, Casus Belli, e Ocupação Prolongada}

Desta forma, levanta-se a questão do que as forças armadas do Japão Imperial fizeram na China por I5 anos e, mais especificamente, se constantemente lutaram contra as forças de insurgência chinesas e grupos de guerrilha, enquanto cometiam atrocidades como as regularmente descritas nos escritos históricos estereotipados do mainstream (Bentley et al 20II). Os registros mostram que batalhas plenas foram mantidas brevemente nos seis meses iniciais e que, durante os I5 anos seguintes, as forças japonesas se engajaram no equivalente da atual guerra de contra-insurgência, enquanto enfrentavam confrontos e ataques de guerrilha esporádicos. As forças chinesas, incluindo Nacionalistas, Comunistas e Senhores-de-Guerra, estavam tão mal organizadas, equipadas e treinadas que não conseguiam conter efetivamente as forças japonesas, que na época eram o único exército moderno na Ásia. Contudo, as forças japonesas não conseguiam usar suas vantagens organizacional e tecnológica ante as forças chinesas durante a guerra urbana. Além disso, um milhão de soldados dificilmente satisfaziam as necessidades de poder humano que eram essenciais para manter a paz e a ordem nas grandes cidades e, logicamente, não conseguiam controlar efetivamente as grandes áreas rurais fora das cidades (NIDS i968; NIDS I97I).

Anteriormente à invasão da China, o chamado "argumento do único-golpe", ou a então versão japonesa de "Choque e Pavor", foi a voz predominante, embora de vida curta, no discurso público japonês (Imaoka I999). Na verdade, o "único golpe" resultou no enfraquecimento do governo central dos Nacionalistas na República da China, incluindo a aceleração de conflitos políticos e armados entre os chineses. Os Nacionalistas estavam severamente divididos. Os Comunistas tentavam diminuir o apoio popular aos Nacionalistas enquanto tiravam vantagens da frente comum em conjunto com estes contra o Japão. A situação tornou-se ainda mais complicada pela ação de senhores-de-guerra locais e de grupos criminosos organizados em larga escala. O governo japonês rejeitou qualquer acordo negociado com o governo Nacionalista, fundamentando-se na recusa a qualquer acordo ao passo que mantinha sua resistência realocando-se mais para o interior e centrando-se em Chongqing, que seria a capital provisória. Consequentemente, o governo japonês não conseguiu achar um parceiro chinês efetivo para negociar e atingir um acordo político, de modo que se viu forçado a instalar uma série de governos fantoches pelo continente. O governo japonês buscou em vão a sinização das 
tropas de segurança locais para diminuir seu próprio fardo militar (Tateyama I999; Tanaka 20I4; Billingsleyı994).

Não é necessário dizer que o antigo impasse Japonês e o atual dos EUA possuem notáveis similaridades. Os dois países subestimaram seriamente a resistência após uma grande vitória militar, ingenuamente acreditando na ideia de que tal vitória levaria automaticamente ao triunfo.

Suficientemente surpreendente, importantes jornais japoneses e outros materiais históricos, como diários de soldados comuns da época, mostram que não somente o governo japonês, mas também a população, justificavam as operações militares na China apelando ao nobre argumento de que o Japão salvaria o povo chinês que sofria com a desordem crescente, trazendo, assim, modernidade e prosperidade (Maesawa 2004). Com a presença militar prolongada na China, contudo, o Japão acabou por perder-se do argumento em si. Isto porque as forças japonesas acabaram tornando-se tropas de ocupação por completo, embora inicialmente fossem servir como salvadoras. Sob aquele argumento, os japoneses não podiam demonizar os chineses como imorais e cruéis inimigos merecedores da destruição total e liquidação. Isto contrasta em muito com os Estados Unidos que usaram bombardeamentos extensivos e estratégicos contra a Alemanha Nazista e o Japão militarista, além das bombas atômicas contra o último.

Novamente, outra surpreendente similaridade é o fato de que, em 2003, o povo americano apoiava fortemente a guerra contra o Iraque em nome da liberdade e da democracia, mas rapidamente viu-se a causa severamente minada pela presença militar prolongada na região, assim como pela incapacidade de encontrar armas de destruição em massa no Iraque pós-guerra como casus belli. Independentemente da justificativa, a própria existência das tropas de um país sobre o território de um terceiro país durante um longo período de tempo, sem o consentimento genuíno deste último, se tornará inescapavelmente um caso evidente de invasão estrangeira.

\section{2) Expansão Incontrolável do Front}

Envolvido na questão chinesa e sendo pressionado intensamente pelos militares, a liderança do Japão imperial expandiu os fronts de guerra ao longo da China e, eventualmente, da região mais ampla do Leste Asiático como um todo. Originalmente, o front de guerra se limitava à Manchúria e à China propriamente, mas, durante o período que se seguiu, a liderança estabeleceu múltiplos fronts um após o outro pelo continente. Tal erro estratégico continuou a ser cometido, motivado em parte para assegurar mínimas esferas de interesse ao garantir a segurança das áreas ao redor destas esferas. 
Frente a uma insegurança que não dava sinais de diminuir, esta abordagem somente resultou em uma espiral descendente de expansão, ocupação e outra expansão. A liderança japonesa continuamente aumentou os riscos da guerra de contra-insurgência, enquanto nenhum líder estava disposto a aceitar a responsabilidade política da situação impossível de ser ganha na China e a iminente derrota esmagadora com os Estados Unidos (Morley I983).

Novamente, isto tem outro ponto em comum em relação às assim chamadas "Regras de Rumsfeld": se você não consegue consertar um problema, torne-o maior (Frum 2007). De fato, a administração Bush implementou tropas significativas no Iraque (Bush 2007a), enquanto despachava o segundo grupo de batalha de porta-aviões e o segundo grupo de ataque expedicionário (Abbas 2007; Reeves 2007). A administração também indicou que iria abrir o segundo front com o Irã, e possivelmente um terceiro com a Síria (Bush 2007b). Obviamente, a administração não estava ciente de estar tendo uma mentalidade similar àquela dos líderes militares do Japão e, assim, de ter uma grande propensão a cair em armadilhas comparáveis.

\section{3) Atrocidades e Direito Internacional}

No campo de batalha, atrocidades são propensas a serem cometidas em guerra de contra-insurgência. O assim chamado Estupro de Nanjing é há muito considerado um exemplo infame (Chang 1997). Após extensivas pesquisas em arquivos, entretanto, muitos historiadores Japoneses chegaram ao consenso de que as 300.000 mortes alegadas foram uma fabricação do Departamento de Propaganda do Partido Nacionalista Chinês. Na verdade, a população estimada do período pré-ocupação da cidade de Nanjing era de cerca de 200.000 (Higashinakano 2005). Ainda, há uma extensa discussão entre eles quanto à provável execução de ao menos alguns milhares de soldados chineses. Depois que as forças japonesas aproximaram-se da cidade, a então capital da República da China, o comandante chinês fugiu. Consequentemente, soldados chineses entraram em pânico e se esconderam nas zonas de segurança criadas para os civis, retirando seus uniformes militares e usando roupas civis, enquanto ainda mantinham suas armas (Higanshinakano 2003). Seus atos constituem uma séria violação das regras costumárias de guerra, codificadas na Convenção de Genebra, a qual requer uniforme e insígnia como essenciais para distinguir os combatentes dos não-combatentes. Aqueles que falham em cumprir estes requerimentos estariam sujeitos à execução. Entretanto, frente à grande dificuldade de lidar com a nunca experienciada magnitude dos desertores disfarçados, as forças japonesas muito provavelmente implementaram execuções em massa sem recorrer aos proce- 
dimentos necessários da corte marcial.

Isto é similar a guerra de contrainsurgência em Fallujah, no Iraque. De fato, as forças dos EUA aniquilaram a cidade, matando praticamente todos, tanto jovens quanto velhos, homens e mulheres, após os avisos e procedimentos necessários. Os insurgentes na cidade não se preocuparam em seguir a Convenção de Genebra quanto aos requerimentos para combatentes. Assim, as forças dos EUA se viram compelida a matá-los todos, quando necessário, a fim de evitar ataques esporádicos, organizados ou suicidas com armas escondidas e explosivos (West 2006).

Por último, mas não menos importante, o Japão Imperial enfrentava forte rejeição nacionalista chinesa contra os interesses japoneses velados na China, que eram legitimados pelo direito internacional. Durante aquele período, o Japão, assim como outras potências ocidentais, possuíam uma variedade de interesses e concessões coloniais e semicoloniais na China, baseados em acordos e tratados. Especificamente, o Japão os obteve às custas de amplos e cumulativos gastos militares e baixas de guerra, incluindo os decorrentes da Guerra Sino-japonesa e da Guerra Russo-japonesa. Não é de espantar que o governo e a população japoneses considerassem a proteção de interesses e da esfera de influência como o ponto chave para a segurança e prosperidade nacionais. Certamente, tais interesses velados surgiram no contexto do imperialismo e colonialismo Ocidentais. Porém, o governo e a população japoneses acreditavam então que a eventual eliminação destes interesses devia ser feita por procedimentos de passo em passo, como requerido pelo direito internacional, dado que os interesses em si haviam sido originalmente estabelecidos como arranjos legais internacionais. Essa noção era particularmente forte no Japão, porque o país havia sido forçado a concluir tratados desiguais com potências ocidentais antes de iniciar sua modernização, e porque o próprio país passou por uma tormentosa e cansativa revisão dos tratados (Kawakami i937; Towsend I939; MacMurray I935).

Todavia, sob o sistema de Tratados de Washington, o Japão e as potências ocidentais concordaram em desmantelar tais arranjos legais com o passar do tempo. Não obstante, o governo e a população da República da China rejeitaram seguir procedimentos legais pacíficos e, ao invés disso, recorriam à violência e obstrução. Esta propensão já era evidente até mesmo anteriormente, nos últimos dias da Dinastia Qing, como tipificado na Rebelião Boxer de I900, a qual atacou embaixadas ocidentais e japonesa em Pequim. Como demonstraram o Incidente Jinan de I928 e o Motim Tongzhou de I937, funcionários de consulados, militares, servidores japoneses e até mesmo civis residentes na China tornaram-se alvos das atrocidades e vandalismo chineses, incluindo carnificinas, estupros e mutilações terríveis. Uma série de provo- 
cações chinesas contra vidas japonesas, direitos de propriedade e interesses velados aprofundou um senso de frustração no Japão, acarretando em um surto de apoio popular à intervenção armada na China. Este processo consistiu em uma corrente de eventos, caracterizada por provocações chinesas e reações exageradas japonesas, culminando, com o tempo, na invasão da China. No fim das contas, havia um ressentimento e resistência crescente da China contra o sistema interestatal ocidental no geral e o direito internacional em particular (Kawakami i937; Towsend I939; MacMurray I935).

Novamente, isto constitui outro forte paralelo entre o passado imbróglio japonês e o impasse contemporâneo dos EUA. Os Estados Unidos estiveram profundamente engajados no Oriente Médio por razões geoestratégicas e geoeconômicas, especialmente petróleo. O país também tem sido o garantidor da segurança de Israel, cuja existência foi firmemente estabelecida sob o Direito Internacional. Por outro lado, os árabes rejeitaram a legitimidade da existência de Israel em si. Os Estados Unidos sofreram a crise dos reféns em Teerã, no Iraque (I979-198I), os ataques do II de setembro, e os enforcamentos brutais de civis americanos no Iraque ocupado (Genttleman 2004), entre outros. Os Estados Unidos mantiveram sua presença militar, antes na Arábia Saudita e no Iraque, e agora na região do Golfo e outros países por meio de acordos internacionais, enquanto exercia uma série de ações militares através da região.

Ao longo de décadas, tem-se visto uma cadeia de eventos de provocações árabes e reações exageradas dos Estados Unidos através da região, as quais atingiram seu auge com as presenças militares concomitantes no Afeganistão e no Iraque sob a administração Bush. A perspectiva atual permite dizer que sua política militar no Iraque carecia de um senso prudência. Contudo, diante das sensações acumuladas de raiva e frustração, o povo americano apoiava então a administração firmemente a assumir uma abordagem mais imprudente, ao menos nos estágios iniciais dos conflitos armados no Afeganistão, Iraque e no grande Oriente Médio. Com suas tropas travadas no Iraque, os Estados Unidos reduziram a si mesmos, com o passar do tempo, de um agente autoproclamado da liberdade e da democracia a um intervencionista armado indesejado, e, para muitos árabes, simplesmente a um agressor. No fim das contas, havia um ressentimento e resistência crescentes entre os árabes quanto ao sistema interestatal ocidental, no geral, e o direito internacional, em particular. 


\section{Como explicar as similaridades}

Por que os chineses demonstraram ressentimento e resistência crescente frente ao Japão Imperial? Por que os árabes atualmente portam-se de maneira muito similar frente aos Estados Unidos? Por que encontrar uma saída de uma guerra de contra-insurgência prologada é um objetivo difícil de ser alcançado?

Para responder estas questões é crucial compreender as características essenciais do processo da história mundial, especialmente a partir das últimas centenas de anos. Contudo, a história mundial genuína começou com o advento do Império Mongol no século XIV, o qual cobria uma porção significativa do espaço eurasiano. Antes do Império, havia apenas uma mistura heterogênea de histórias locais e regionais sem dinâmicas que as integrassem como um todo, não havia uma história mundial. Os Mongóis foram os primeiros a construir uma ampla rede de comunicação e transporte a cavalo na Eurásia. Mesmo após o colapso do Império, a ordem imperial continuou a existir como o modo organizacional predominante e de larga escala da sociedade humana. O império dividiu-se em vários impérios regionais, sendo substituído então, por exemplo, pelos impérios Tamerlão, Mogol, Otomano e os diferentes impérios chineses.

Sob uma ordem imperial, os indivíduos identificam a si mesmos primeiramente e, acima de tudo, como sujeitos a um império. Suas identidades paroquiais, étnicas, religiosas, sectárias, locais e de classe tornam-se secundárias e, por vezes, focos insignificantes de conflitos políticos. Isto ocorre porque uma ordem imperial tolera pacificamente a coexistência de várias comunidades baseadas em identidades diversas, enquanto não falha em aniquilar sem misericórdia os rebeldes, como tipificados pelas práticas do império Mongol.

Mais tarde, o modo imperial de ordem enfrentou desafios intransponíveis advindos da ascensão dos Estados-nação. Isto é demonstrado pelo fato de que impérios tradicionais eventualmente colapsaram devido à desordem, à subjugação, e ao subdesenvolvimento frente aos grandes Estados-nação ocidentais modernos. O poder militar destes últimos ultrapassava o dos primeiros em termos de organização social, tecnologia e produção industrial. A evolução política de monarquias absolutistas para revoluções burguesas, de um lado, e a emergência de revoluções industriais, de outro, foram uma combinação efetiva destes fatores.

Surpreendentemente, a chave para a transformação reside na era medieval que somente a Europa ocidental e o Japão experienciaram (Umesao I974). Ambos não foram invadidos pelas ondas de grupos nômades mon- 
góis, graças às características topográficas e à árdua resistência. Os grupos nômades não conseguiam marchar em massa no arquipélago montanhoso do Japão, ao passo que terrenos montanhosos, rios largos e a vegetação de clima temperado impediam os mongóis de avançar para a Europa ocidental. Devido às características topográficas e climáticas em comum, pequenas comunidades políticas se desenvolveram tanto na Europa Ocidental quanto no Japão, e estas comunidades continuamente lutaram umas com as outras, o que resultou em culturas beligerantes e estratégicas e na aceleração do aprimoramento de habilidades militares. Não é de surpreender que os últimos dois ou três séculos foram de predominância do sistema interestatal ocidental enquanto os impérios tradicionais desapareceram após derrotas esmagadoras das potências ocidentais e do Japão, que fez com sucesso sua entrada no sistema interestatal ocidental.

Hoje, muitos povos no mundo desenvolvido enfrentam grande dificuldade em nation-building como um grande pré-requisito para nation-state building. Isto ocorre porque o desaparecimento das ordens imperiais os deixaram com múltiplas identidades, como étnica, religiosa, sectária, local e de classe, que se sobrepõem por vezes, e ainda significativamente competem umas com as outras, chegando a entrarem em conflito. Sem uma identidade nacional coesa, os povos após os impérios não conseguem definir seus interesses sociais comuns como a base de resolução de conflitos sociopolíticos, particularmente a alocação de riqueza e as oportunidades político-econômicas relacionadas à alocação. Como resultado, estes povos não foram capazes de construir ordens políticas alternativas. Isto é exatamente o que aconteceu no Iraque pós-Saddam, assim como na China pós o colapso da Dinastia Qing.

Em suma, é crucial entender que o mundo atual está no contínuo processo macro-histórico contínuo decorrente do colapso das ordens imperiais e da desordem subsequente. Isto é, o Oriente Médio passa por um processo pós-Império Otomano e, em menor grau, a China passa por um pós-Qing. O Japão teve um importante papel na formação da identidade nacional chinesa, dado que esta resultou de contínuas pressões cultural, econômica, política e militar japonesas após a derrota chinesa na guerra contra o Japão em I895. Mao afirmou que os Chineses não teriam conseguido se salvar de fragmentação severa e atingir a unificação sob o Partido Comunista sem as pressões japonesas (Mao I964). Tais pressões continuam a existir ainda hoje, apesar da pressão militar ser fraca. De fato, embora os chineses ainda possuam identidades étnica, local, de classe, entre outras, que competem entre si e carecem de um senso de identidade nacional mais profundo, sentimentos anti-japoneses frequentemente tornam a identidade incoerente temporariamente coesa, o que acaba por afetar a estabilidade das relações sino-japonesas. 
Similarmente, sentimentos anti-americanos crescentes geraram um efeito unificador significativo entre a população do Oriente Médio, tanto árabes quanto não-árabes, os quais teriam permanecido indefinidamente fragmentados devido às identidades em conflito. Ironicamente, foram as pressões cultural, econômica, política e militar Americanas e a intensificada intervenção armada dos EUA após o II de Setembro em particular que resultaram no alinhamento conveniente, embora ainda temporário por natureza, entre rivais tradicionalmente sectários, como o Hamas Sunni, e o Hezbollah Xiita e o Irã.

Tanto o Japão quanto os EUA estiveram envolvidos na China e no Oriente Médio, respectivamente, como intervencionistas altamente modernizadores. Seus envolvimentos resultaram nas transformações culturais, econômicas, sociais e políticas das duas regiões, enquanto ao mesmo tempo mitigaram e agravaram as contradições socioeconômicas e sociopolíticas. O Japão e os EUA são, então, parcialmente responsáveis pelos problemas que a China e o Oriente Médio lutam para resolver ou administrar. Contudo, a raiz destes problemas reside na falta de uma identidade nacional incorporada sólida ou profundamente, sem a qual uma ordem política não consegue ser construída, e sem a qual o desenvolvimento e a modernização e, eventualmente, a liberdade e a democracia, não são alcançadas. Culpar os japoneses e os americanos e tentar reduzir todos os problemas a eles constitui-se simplesmente em tentar evadir-se de confrontar realidades dolorosas.

\section{0 que fazer quanto ao Oriente Médio}

De tal maneira, este estudo deixou claro que, como tipificado pelos japoneses imperiais e os líderes dos EUA contemporâneos, o mundo não esteve completamente ciente da importância central do processo macro-histórico após os impérios e dos sérios constrangimentos quanto à engenharia social para atingir modernização e desenvolvimento, e liberdade e democracia. Isto é compreensível porque o Japão passou pela era Medieval no oriente e porque os americanos herdaram a experiência da era Medieval da Europa ocidental no ocidente. É necessário reduzir o nível de expectativa quanto ao escopo e ao tempo da transformação alcançável no mundo em desenvolvimento após os impérios.

A fim de não repetir os erros japoneses na China, os americanos devem se dar conta que a utilidade de instrumentos militares é muito limitada. O problema é macro-histórico por natureza, e a solução deve ser política em essência. Instrumentos militares somente são eficazes quando são empregados para atingir objetivos políticos bem definidos e, portanto, limitados. 
Assim como o Japão Imperial permaneceu por longo tempo envolvido na China, os Estados Unidos não conseguirão sair facilmente do Oriente Médio. Ainda, a retirada prematura das forças militares provavelmente tornará pior a situação, na medida em que os EUA se veriam compelidos a desistir de objetivos políticos mínimos estabelecidos anteriormente à intervenção armada. Enquanto os riscos permanecem muito altos, objetivos menos ambiciosos devem ser estabelecidos.

Dada a experiência japonesa na China, os Estados Unidos estão bem aconselhados a não se envolverem profundamente em nation-building, com o argumento de que irão inescapavelmente carregar os fardos de assegurar a segurança doméstica em uma nação em construção. Os EUA não devem intervir em uma guerra civil sectária de soma zero, e devem restringir-se a resguardar o processo de nation-building no Oriente Médio de invasões estrangeiras, particularmente de Irã, Síria, Al-Qaeda, e outros grupos jihadistas extremistas, e a assegurar os governos fantoches que instalou, por exemplo, em Bagdá e em Kabul. Deve ser ressaltado que a criação instantânea de uma identidade nacional coerente é impossível e que, caso haja uma identidade nacional precária, esta será uma identidade anti-americana.

Baseando-se no fracasso Japonês na China, os Estados Unidos são encorajados a não abrirem um segundo e um terceiro front: o país não deve cair na abordagem de Rumsfeld. Do contrário, os EUA muito provavelmente sofreriam de enormes perdas humanas e de liderança. No pior cenário, os Estados Unidos podem perder todas as suas posições estratégicas de defesa e sua presença militar na região.

\section{REFERÊNCIAS}

Abbas, Mohammed. 2007. "Nine U.S. warships in Gulf for show of force". Reuters. Accessed December 7, 20I4. http://www.reuters.com/ article/2007/05/23/us-gulf-usa-ships-idUSL2360749620070523?feed Type $=$ RSS.

Asada, Sadao, (eds.). I989. International Studies in Japan: A Bibliographic Guide, Tokyo: Japan Association on International Relations.

Barno, David W., Nora Bensahel, and Travis Sharp. 20II. Hard Choices: Responsible Defense in an Age of Austerity, Washington, D.C.: Center for a New American Century, I3-22.

Jowett, Bernard J. I999. The Japanese Army 1931-45 (Volume 2, 1942-45). Oxford: Osprey Publishing.

Bentley, Jerry, Herbert Ziegler and Heather Streets Salter. 20II. Traditions Q 
Encounters: A Global Perspective on the Past. New York: McGraw-Hills. Billingsley, Philip Richard Billingsley. 1994. Hizoku: Kindai Chugoku no henkyo to chuo (Bandits in Republic of China). Tokyo: Chikuma Shobo. Bush, G.W. 2007. “President's Address to the Nation”. White House. Accessed December 7, 20I4. http://georgewbush-whitehouse.archives.gov/ news/releases/2007/0I/20070IIo-7.html.

. 2007. “Transcript of President Bush's Address to Nation on U.S. Policy in Iraq”. New York Times. Accessed December 7, 20I4. http://www. nytimes.com/2007/or/II/us/IIptext.html?pagewanted=print\&_r\&_ $\mathrm{r}=\mathrm{I} \&$.

Chang, Iris. I997. The Rape of Nanking: The Forgotten Holocaust of World War II. New York: Basic Books.

Frum, David. 2007. "If you can't fix a problem, make it bigger", Marketplace. Accessed December 7, 20I4. http://www.marketplace.org/topics/ifyou-cant-fix-problem-make-it-bigger.

Gettleman, Jeffrey. 2004. "Enraged Mob in Fallujah Kills 4 American Contractors. New York Times. Accessed December 7, 20I4. http://www. nytimes.com/2004/03/3I/international/worldspecial/3ICND-IRAQ. html.

Higashinakano, Shudo. 2003. 1937 Nankin-Koryakusen no Shinjitsu: Shinshiryo-Hattsskutsu (Truth of I937 Nanjing Cheats leg - new material excavation). Tokyo: Shogakukan Bunko.

2005. The Nanking Massacre: Fact versus Fiction: A Historian's Quest for the Truth. Tokyo: Publisher: Sekai Shupan.

Imaoka, Yutaka. I999. Ishihara Kanji no Higeki (The Tragedy of Gen. Kanji Ishihara). Tokyo: Fuyo Shobo Shutsupan, Chapter 5.

Kawakami, Kiyoshi Karl. 1939. Japan in China: Her Motives and Aims. London: J. Murray.

MacMurry, John Van Antwerp. I935. Development Affecting American Policy in the Far East. Stanford: Hoover Institution Press.

Maesawa, Toshiyuki. 2004. "Nitsuchu-Senso wo kyokoku-Itsuchi-Hodo de Shiji shita Shinbum-Media (The Japanese Newspaper media reported the whole nation supported the Sino-Japanese War). Maechan. Accessed December 8, 20I4. http://maechan.sakura.ne.jp/war/data/hhkn/34.pd f\#search=\%27\%E6\%97\%A5\%E4\%B8\%AD\%E6\%88\%A6\%E4\%BA\%

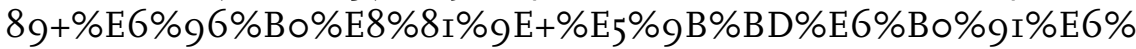
$94 \% \mathrm{AF} \% \mathrm{E} 6 \% 8 \mathrm{C} \% 8 \mathrm{I} \% 27$

Mao Zedong. 1964. Shakaishugi no Riron to Jitsusen (The Theory and Practice 
of Socialism). The record of the meeting of Mao and Kozo Sasaki, President of the Japan Socialist Party, of July Io, I964.

Morley, James William, (ed.). I983. The China quagmire: Japan's expansion on the Asian continent, 1933-1941: selected translations from Taiheiyo Senso e no michi, kaisen gaiko shi. New York: Columbia University Press.

National Intelligence Council. 2012. Global World in 2030: Alternative Worlds, Washington, D.C., p. iii (NIC2OI2-OOI). Accessed September 9, 2013. http://publicintelligence.net/global-trends-2030/.

NIDS (Boeicho Boeikennshujyo Senshishitsu: War History Unit, National Institute for Defense Studies, Japan Defense Agency). i968. Hokushi No Chiansen (The Peace-Keeping Operation of the Imperial Japanese Army) $<$ I $>$. Tokyo: Asagumo Shinbum.

I97I. Hokushi No Chiansen (The Peace-Keeping Operation of the Imperial Japanese Army) <2>. Tokyo: Asagumo Shinbum.

. 1974. Kantokuen/shuusen-ji o Taiso-sen (The Kwangtung Army <2> The Kwantung Army Special Exercise: anti-Soviet Operation at the end of the war). Tokyo: Asagumo Shinbum.

Reeves, Ron. 2007. "JCSCSG Arrives in Pearl Harbor". NNSo7082I-II. USS John C. Stennis Public Affairs, August 2I, 2007. Accessed December 7 , 2014. http://www.navy.mil/submit/display.asp?story_id=31336.

Tanaka, Hideo. 20I4. Nihon wa ikanishite Chugoku tono Senso ni Hikizurikomaretaka: Shinatsu-Ggunjin Sasaki Touichi no Ashiato kara Yomitoku (How Japan was dragged into the War with China: An Indepth Analysis from the Personal History of An Imperial Japanese Army Intelligence Officer/China Expert, Sasaki Touichi). Tokyo: Soushisha.

Tateyama, Ryoich. 1999. Nihon-Rikugun to Chugoku: 'Shina-tsu' ni miru Yume to Satetsu (The Japanese Imperial Army and China: Dream and Failure as found in its China Hands). Tokyo: Kodansha.

Townsend, Ralph. 1939. Ways That Are Dark: The Truth about China. New York: G.P. Putnam.

Umesao, Tadao. I974. Bunmei no Seitai-shikan (An Ecological Perspective of Civilization). Tokyo: Chuokoron, 20I-204.

West, Bing. 2006. No True Glory: A Frontline Account of the Battle for Fallujah. New York: Bantam Book. 


\section{RESUMO}

Este estudo apresentará, em primeiro lugar, uma série de notáveis similaridades entre o imbróglio do Japão Imperial na China e o impasse contemporâneo dos EUA no Iraque pós-Saddam. Em segundo lugar, fornecerá uma perspectiva teórica do porquê tais casos compartilham tais similaridades. Em terceiro lugar, o estudo explorará as implicações desta perspectiva para a política internacional, focando-se no futuro da hegemonia dos EUA. O estudo baseia-se no entendimento básico de que o mundo em desenvolvimento ao longo de regiões continua a sofrer o mesmo e contínuo processo macro-histórico consequente do desmantelamento dos impérios como o modo organizacional antes predominante das sociedades humanas. A análise defende a importância central de uma identidade nacional estável para a modernização e o desenvolvimento, assim como para a liberdade e a democracia.

\section{PALAVRAS-CHAVE}

Guerra de Contra-insurgência; Japão Imperial; EUA; China; Iraque Pós-Saddam; Identidade Nacional.

Recebido em 15 dezembro de 2014. Aprovado em 20 de julho de 2015.

Traduzido por Luísa Acauan Lorentz 


\title{
A EMERGÊNCIA DA PERIFERIA NO SISTEMA MUNDIAL: DA CONFERÊNCIA DE BANDUNG À CONFERÊNCIA DE BUENOS AIRES (1955-1978)
}

\author{
Analúcia Danilevicz Pereira' \\ Klei Medeiros ${ }^{2}$
}

\section{Introdução}

A história do sistema mundial implica a existência de regiões centrais e periféricas. Antes da descolonização dos povos, as relações entre a periferia se deram em escala reduzida e intermediadas pelo centro ${ }^{3}$. Nesse sentido, a Conferência de Bandung e outros mecanismos multilaterais como o Movimento dos Não-Alinhados e o G-77 inauguram uma nova etapa na história mundial, sendo o ponta pé inicial do desenvolvimento das relações sul-sul. Pela primeira vez, a periferia do sistema mundial passa a se organizar em torno de princípios, valores e ideias comuns que serviriam de base para as suas estratégias de atuação externa em um contexto de Guerra Fria. Neste primeiro

I Professora de Relações Internacionais e dos Programas de Pós-Graduação em Estudos Estratégicos Internacionais e em Ciência Política da UFRGS. Pesquisadora do NERINT/UFRGS e coordenadora do CEBRAFRICA/UFRGS. E-mail: ana.danilevicz@ufrgs.br

2 Mestrando em Ciência Política na Universidade Federal do Rio Grande do Sul (UFRGS), Graduando em Relações Internacionais na mesma universidade e Bacharel em Administração na Pontificia Universidade Católica do Rio Grande do Sul (PUCRS). É pesquisador do Centro de Estudos Internacionais sobre Governo (CEGOV). E-mail: kleimedeiros@gmail.com

3 O caso, por exemplo, do comércio triangular que ligava a Europa com a América e com a África, movimentando fatores de produção entre os três continentes criou um dos principais mecanismos de engenharia social da era moderna: os sistemas de plantations na América (OSTERHAMMEL \& PETERSON, 2005). Tratava-se de um arranjo Sul-Norte-Sul, em que havia pouca margem de manobra para o desenvolvimento de relações autônomas entre América e África. 
momento, as demandas principais eram acelerar a descolonização e garantir o não-alinhamento a nenhuma das potências no contexto da Guerra Fria, mantendo uma autonomia que permitisse a soberania e autodeterminação dos povos. Nesse sentido, este artigo tem como objetivo caracterizar e periodizar historicamente a evolução das relações entre a periferia, com destaque para o momento de prelúdio da atual Cooperação Sul-Sul, desenvolvido entre os anos I950 e I970, que teria assentado as bases para uma agenda econômica, política e social, que seria resgatada de certa forma no momento recente, porém sob novas bases de organização.

Assim como a realização da Conferência de Bandung contou com o papel fundamental da articulação entre Índia e China, temos na atualidade uma discussão importante sobre o papel que países intermediários vêm exercendo na promoção da Cooperação Sul-Sul. A semiperiferia se coloca como porta-voz legítima do desenvolvimento dos países do Sul, mas ao mesmo tempo é acusada de atuar da mesma forma que os países centrais, sob a lógica de ampliação dos mercados e dos seus interesses estratégicos no âmbito global. Nesse sentido, é fundamental uma discussão que resgate os princípios basilares da Conferência de Bandung, pautados na não-interferência em assuntos internos de outros países e na necessidade de desenvolver relações horizontais entre países subdesenvolvidos, baseadas na cooperação e na ideia de reciprocidade.

Historicamente, podemos reconhecer a Europa durante a época feudal como região periférica em relação ao mundo árabe-islâmico (Norte da África e Oriente Médio), dentro de sistemas regionais que funcionavam a partir de uma lógica tributária, na qual a distribuição de recursos se dava de acordo com a centralização de poder. Inúmeras formas protocapitalistas existiram tanto na Europa quanto em outras regiões, baseadas na organização do trabalho e do capital em grandes cidades mercantis. Estas formas protocapitalistas se desenvolveram justamente na Europa no contexto da expansão marítima (e consequentemente territorial) e se refletiram na criação de um novo sistema mundial capitalista, em que a Europa não mais seria a região periférica (Amin I997).

O sistema mundial capitalista atravessa séculos de longos ciclos de acumulação e retração, com a consequente ascensão e queda de grandes potências. Se até o século XIX teríamos sucessivas hegemonias de países europeus, que se desenvolviam através de uma concorrência dos Estados pelos capitais circulantes, o século XX traz à tona a Pax Americana, após duas guerras mundiais que rearranjaram o equilíbrio de poder mundial. Em termos econômicos, isso não significou a relegação da Europa à uma nova condição de periferia, visto que logo após a Segunda Guerra boa parte dos investimen- 
tos norte-americanos se destinaram à sua reconstrução, dentro de uma lógica de Cooperação Norte-Norte. Tal atitude foi necessária para dar continuidade à expansão do sistema capitalista mundial e assegurar o monopólio das potências capitalistas do Norte sobre a governança global. A fracassada tentativa do Brasil em ser o sexto membro permanente do Conselho de Segurança da ONU evidenciou que o Terceiro Mundo não teria voz nas questões estratégicas internacionais.

Dado que o sistema-mundo capitalista se expandiu devido não apenas à competição interestatal pelo capital circulante, mas também à formação de estruturas políticas dotadas de capacidades organizacionais cada vez mais amplas e complexas para controlar o meio social e político, o que se verificou entre as potências do Norte foi não somente uma concorrência, mas uma concentração do poder político cada vez maior (Arrighi I996). Aos países latino-americanos e às colônias afro-asiáticas, que compunham grande parte da população e territórios mundiais, seria garantido pouco espaço de atuação e manobra para o seu desenvolvimento e autonomia. Apesar disso, a dimensão política do subsistema socialista representava, durante a Guerra Fria, uma alternativa possível em um contexto em que as lutas de libertação nacional clamavam por maior autonomia e independência frente às metrópoles capitalistas. É nesse contexto que tem surgimento a ideia de Terceiro Mundo, de Não-Alinhamento e de substituição da luta política Leste-Oeste por uma luta econômica Norte-Sul ${ }^{4}$.

Dentro desse contexto, o presente artigo se propõe a uma abordagem histórico-analítica sobre a emergência da periferia, suas principais demandas e formas de articulação. Para tanto, metodologicamente serão identificados diferentes momentos pelos quais as relações sul-sul passaram. Geograficamente, será destacada a expansão das ideias e práticas terceiro-mundistas, que em um primeiro momento irão se concentrar exclusivamente em parte da Ásia e da África (Grupo de Bandung) e depois irão se consolidar na América Latina, sobretudo nos anos 70. Além disso, serão destacadas, de acordo com a teoria da ação coletiva (Olson I965), características do arranjo organizacional entre a periferia, suas estratégias de atuação e os instrumentos utilizados para garantir coesão do bloco em cada período. Concomitantemente, será destacado o lugar da periferia no sistema-mundo atual (Amin I997; Amin 20Io; Arrighi I996; Wallerstein I992).

Na primeira seção deste artigo, será analisada a fase inicial das Relações Sul-Sul, situando a Conferência de Bandung como marco inicial do esta-

4 A coadunação das ideias de independência nacional e socialismo foi a fonte ideológica principal com a qual se desenvolveriam os princípios de uma parte do Terceiro Mundo (lembrando que a maioria dos países participantes da Conferência de Bandung se declaravam socialistas). 
belecimento de uma estratégia comum, bem como de princípios e valores que iriam reger as relações entre países do Terceiro Mundo. Institucionalmente, são criados o Movimento dos Não Alinhados (MNAL) e o G-77, e são apresentadas as primeiras iniciativas políticas e econômicas de cooperação entre países do Sul. Os novos países independentes (no sentido formal) reagem ao neocolonialismo através da tentativa de estabelecer relações horizontais com países que enfrentam problemas comuns, como desigualdade, pobreza, fome e altos índices de mortalidade infantil.

Essas reivindicações apresentadas nos princípios de Bandung e nas diversas conferências que tratariam do tema do desenvolvimento na época, passariam a ser defendidas no âmbito da ONU, que passaria a constantemente institucionalizar e englobar a agenda da Cooperação Sul-Sul. Para tanto, na segunda seção do artigo serão destacadas as principais questões apresentadas por países do Sul em termos de agenda política e econômica em organizações internacionais, no contexto de acirramento da disputa bipolar da Guerra Fria nos anos 1970. Em 1978, pela primeira vez em uma Conferência da ONU é utilizado o conceito de Cooperação Sul-Sul, e dela se segue na década de I980 um certo esfriamento das relações entre a periferia dado o contexto de acentuação da disputa Leste-Oeste, da multiplicação de experiências neoliberais e da cooperação Norte-Sul com condicionalidades, sobretudo as exigências de ajustes fiscais e austeridade econômica como critério para o recebimento de auxílio. Sendo assim, na terceira seção do artigo, que consiste nas conclusões, será analisado o momento atual da Cooperação Sul-Sul, que após o refluxo da década neoliberal alcança novo ânimo político sob a forma da criação de coalizões de geometria variável, que acrescentam um componente de revisão da ordem internacional tanto em termos Leste-Oeste, quanto Norte-Sul.

\section{De Bandung à Havana (1955-1966): Descolonização e emer- gência de uma Agenda do Terceiro Mundo}

A primeira fase da Guerra Fria se daria em meio a mais uma expansão do sistema mundial capitalista sob a hegemonia norte-americana. Os primeiros anos após a Segunda Guerra Mundial se caracterizariam pela busca por zonas de influência por parte dos EUA e URSS, além da reconstrução da Europa, através do Plano Marshalls, e da transformação do Japão em uma espécie de protetorado dos EUA. Na Ásia em geral, começam a se desenvolver

\footnotetext{
5 Para a Ásia, houve uma espécie de Plano Marshall, o chamado Plano Colombo, que previa ajuda financeira por parte dos EUA para a reconstrução dos países asiáticos devastados pela guerra e para o desenvolvimento socioeconômico dos países da região.
} 
movimentos de libertação nacional que depois iriam se espalhar pela África na década de I960. O fato de os movimentos de libertação terem ocorrido inicialmente na Ásia garantiu a esse continente o status de liderança no processo de formação do Terceiro Mundo, sendo a Conferência de Bandung a manifestação desse protagonismo asiático nos movimentos em prol da descolonização.

Ao se colocarem como uma terceira força no jogo da Guerra Fria, os países asiáticos, especialmente Índia e China, rompem com a ideia de bipolaridade e trazem a ideia de multipolaridade de forma precoce. Nesse sentido, a Pax Americana carrega consigo uma maior instabilidade, visto que, diferentemente do que acontecia nas sucessivas hegemonias europeias dos séculos anteriores, a periferia deixa de estar diretamente atrelada ao centro, na forma de colônias. O fato de Índia e China, diferentemente da União Soviética, terem sido vítimas da colonização, lhes conferiam um grau de legitimidade como porta-vozes e líderes do Terceiro Mundo, o que possui implicações na projeção externa desses dois países no século XXI.

A atuação dos EUA na Ásia já se fazia presente no sentido de ser um substituto à presença francesa e inglesa e pressionar os regimes socialistas da primeira etapa de descolonização (China, Coréia, Vietnã) e as lutas nacionalistas (Índia e Indonésia). Na Ásia, os EUA tinham interesse, como nova potência econômica, em investir seu excedente de capital e expandir os tentáculos de suas empresas transnacionais e, com isso, defendiam a abolição de formas de protecionismo, apoiando a descolonização. Para tanto, parte de sua estratégia consistia em criar um novo polo de poder na Ásia, o Japão, através da restauração da sua economia, além do investimento nas relações com Taiwan, garantindo a soberania dessa ilha de valor estratégico pela proximidade com a China (Visentini 20II).

Especificamente a questão da Indonésia motivou a realização da Conferência de Colombo, onde foi discutida a articulação de uma frente neutralista para contrapor a atuação dos americanos, que tomavam o lugar dos franceses no conflito. A Conferência de Colombo contou com a presença da Índia, Paquistão, Indonésia, Birmânia (Mianmar) e Ceilão (Sri Lanka) e foi uma espécie de ensaio para a Conferência de Bandung ${ }^{6}$, que ocorreria um ano mais

6 Vale ressaltar que antes da Segunda Guerra Mundial e dos movimentos de descolonização, foram realizadas conferências que reuniam colônias europeias. Exemplos são os Congressos de Berlim e de Bruxelas. No Congresso de Berlim, em I926, a Índia apresentou um informe que demonstrava "os limites que a política tradicional dos países europeus impunha a qualquer esforço eficaz em favor da paz e as condições de cooperação entre Europa e Ásia. O primeiro equívoco dos povos da Europa - se lê nesse informe - é que sempre pensam os problemas internacionais em termos exclusivamente europeus; a segunda é que nunca fizeram nada para eliminar a causa eventual da hostilidade da Ásia em relação à Europa” (Guitard I962, II). Na 
tarde. Em 1954, Índia e China declararam conjuntamente cinco princípios que regeriam suas relações: coexistência pacífica, respeito recíproco pela soberania e integridade territorial das partes, não ingerência nos assuntos internos, não-agressão, igualdade e privilégios recíprocos.

Um ano mais tarde, na Conferência de Bandung, pela primeira vez se reúnem representantes dos povos asiáticos e africanos, inaugurando a solidariedade afroasiática e a emergência do Terceiro Mundo no cenário internacional. A Conferência representou o início da tomada de consciência em relação ao papel que os novos países independentes deveriam exercer no mundo, no sentido de representar os excluídos, os oprimidos e os rejeitados nas grandes discussões internacionais do centro. À época dessa conferência, a maioria dos países Ásia já havia conquistado a independência política formal e a luta de libertação nacional na África começava a despontar. Nesse sentido, a conferência reuniu diferentes correntes do mesmo movimento de emancipação, em fases diferentes de desenvolvimento, além de unir países com distintos sistemas políticos, desde países monárquicos até socialistas. A heterogeneidade dos países, que a princípio poderia ser um obstáculo à coordenação da ação coletiva, foi superada pelo desejo comum de todos os países de enfrentar o subdesenvolvimento. Bandung, assim, representava uma tentativa de inverter a lógica da Guerra Fria e propor o debate Norte-Sul, ao invés do Leste-Oeste, e se posicionar como um polo de poder alternativo que tornaria a Guerra Fria bem mais complexa do que aparentemente poderia parecer.

Os princípios fundamentais acordados entre os países participantes foram, sobretudo, a luta contra o colonialismo e o racismo, o direito de todos os povos à autodeterminação (princípio este que já constava na Carta da ONU, mas seria aqui reforçado), a luta pela independência e pela liberdade de escolha dos Estados relativamente aos seus sistemas políticos e opções de inserção externa durante a Guerra Fria. O não-alinhamento, nesse sentido, não significava necessariamente equidistância, mas sim que os países teriam liberdade para se posicionar como preferissem (exemplo disso foi que Chou

Conferência de Bandung, os líderes Sukarno e Nehru lembraram da primeira manifestação de solidariedade entre os povos oprimidos que ocorreu na Conferência de Bruxelas, em I927 e em Berlim em I926. Segundo Guitard (I962, I2), "Berlim era a capital de uma Alemanha que havia sido privada de colônias e que havia se tornado então um dos refúgios dos primeiros nacionalistas dos impérios britânicos, francês e holandês. Foi aí onde os representantes dos povos colonizados, contando com o apoio moral da URSS, alentados e ajudados por certas personalidades políticas, literárias e científicas pertencentes às esquerdas europeias e por determinados governos da América Hispânica, impacientes da tutela econômica dos EUA - o Congresso foi financiado pela China Nacionalista e pelo México - decidiram que se celebraria em Bruxelas, em I927, um congresso dos povos oprimidos [...] Participaram dessa conferência Albert Einstein e a senhora Sun-Yat-Sem, entre outros". 
En Lai, durante a Conferência, fez acenos na direção dos Estados Unidos, propondo aos americanos uma declaração conjunta de coexistência pacífica).

Desse modo, Bandung significou o primeiro concerto entre a periferia sobre a estratégia de atuação coletiva no cenário global. Além disso, representou o surgimento de uma cultura do Sul (Wallerstein I992), e uma agenda do Terceiro Mundo, com suas prioridades vinculadas ao desenvolvimento social, e não apenas econômico. Além disso, Bandung prematuramente lançou a ideia da necessidade de reconhecimento das diferenças, algo que no século XXI ganha força (Fraser 2007). Ao final da conferência, foram declarados em um comunicado contendo cinco sessões: A) Cooperação Econômica; B) Cooperação Cultural; C) Direitos do homem e autodeterminação; D) Problemas dos povos dependentes; E) Promoção da Paz e Cooperação Mundiais.

Com relação à cooperação econômica, foi reconhecida a urgência de promover o desenvolvimento econômico da zona afro-asiática dentro do respeito à independência nacional, por meio da assistência técnica (termo atualmente substituído por "cooperação técnica") entre participantes ou por meio de acordos multilaterais e bilaterais com o resto do mundo. Também foi solicitada a criação de um fundo especial das Nações Unidas para o desenvolvimento econômico e fora recomendado aos países afro-asiáticos que variassem suas exportações "manufaturando" suas matérias-primas e fomentando feiras inter-regionais e intercâmbios de delegações regionais. Além disso, clamou pela criação de uma agência internacional de energia atômica, insistindo sobre a necessidade de utilização desta para fins pacíficos (Guitard I962).

No que tange à cooperação cultural, a declaração final enaltece as riquezas intelectuais da África e Ásia e aconselha o desenvolvimento de missões científicas, literárias e artísticas, o intercâmbio de livros, de professores e estudantes. Na seção "Direitos do homem e autodeterminação", se confirma a necessidade de plena adesão dos participantes à Carta das Nações Unidas e à Declaração Universal dos Direitos do Homem e se ressalta a necessidade dos países já independentes de ajudar os outros países colonizados a conquistar sua soberania. Em relação à "promoção da paz e da cooperação internacional" se manifesta o desejo de que se ampliem a quantidade de organizações internacionais e é solicitado ao Conselho de Segurança da ONU que conceda espaço para a participação dos países afro-asiáticos no seu seio. Além disso, ressaltou-se a defesa do desarmamento e a proibição de armas de destruição em massa, bem como a suspensão dos testes nucleares (Guitard I962). Por fim, o comunicado final da Conferência de Bandung assinala os Dez Princípios da Coexistência, quais sejam: 


\section{Quadro 1: Os Dez Princípios da Coexistência de Bandung}

1. Respeito aos direitos humanos fundamentais, conforme aos fins e aos princípios da Carta das Nações Unidas;

2. Respeito à soberania e à integridade territorial de todas as nações;

3. Reconhecimento da igualdade de todas as raças e a igualdade de todas as nações, pequenas e grandes;

4. Não-intervenção e não-ingerência nos assuntos internos dos outros países;

5. Respeito ao direito de cada nação de defender-se individual e coletivamente conforme a Carta das Nações Unidas;

6. a) Rejeição a todo acordo de defesa coletiva destinado a servir aos interesses particulares das grandes potências quaisquer forem;

b) Rejeição a toda pressão que uma potência, qualquer que seja, tente exercer sobre outra;

7. Abstenção a atos de ameaças de agressão ou uso da força contra a integridade territorial ou a independência política de um país;

8. Resolução de todos os conflitos por meios pacíficos, tais como negociação ou conciliação, arbitragem e resolução diante de tribunais, assim como outros meios pacíficos que possam eleger os países interessados, conforme a Carta das Nações Unidas;

9. Estímulo dos interesses mútuos e a cooperação;

10. Respeito à justiça e às obrigações internacionais.

Fonte: Guitard 1962.

Os Dez Princípios de Bandung traduzem a estratégia global dos países do Terceiro Mundo, em um cenário de Guerra Fria. A preocupação central é evitar um conflito direto ou indireto entre as superpotências e evitar que o sistema de alianças que levou à Segunda Guerra Mundial se repetisse, gerando um novo conflito global. No plano econômico, a conferência materializa aquilo que Samir Amin (20I0) denomina "ideologia do desenvolvimento", que conheceu sua grande época precisamente entre I955 e I975, fase de auge da hegemonia americana no sistema mundial. O desenvolvimento, nesse período é visto como " a vontade de desenvolver as forças produtivas, de diversificar a produção, nomeadamente industrializando, bem como a vontade de assegurar ao Estado nacional a direção e o controle desse processo" (Amin 20IO, $\mathrm{n} / \mathrm{p}$ ). Além de Bandung ter marcado a emergência da periferia no sistema mundial, ela influenciou e inspirou o surgimento do Movimento dos Não-Alinhados (MNAL), a partir da Conferência de Belgrado, em I96I. 
Os princípios de Bandung foram adotados pelo MNAL e o seu cumprimento se tornou o critério para países aderirem ao bloco. A ideia era estimular uma participação ativa na política internacional por parte dos países membros, baseados em princípios, valores e ideias basilares, tais como apoio a autodeterminação, independência nacional, soberania e integridade territorial dos Estados; oposição ao apartheid; a não adesão a pactos militares multilaterais e a independência dos países não-alinhados em relação as rivalidades entre os dois blocos em disputa; a luta contra o imperialismo em todas as suas formas e manifestações; a luta contra o colonialismo, neocolonialismo, racismo, ocupação estrangeira e dominação; o desarmamento; não-ingerência nos assuntos internos dos Estados e a coexistência pacífica entre todas as nações; rejeição do uso ou ameaça de uso da força nas relações internacionais; o fortalecimento das Nações Unidas; a democratização das relações internacionais; o desenvolvimento socioeconômico e a reestruturação do sistema econômico internacional; bem como a cooperação internacional (MNAL 20I5).

Tratam-se de princípios já discutidos em Bandung, mas que seriam institucionalizados a partir do Movimento dos Não-Alinhados, que atuaria, na prática para garantir que os povos oprimidos pela ocupação e dominação estrangeira pudessem exercer seu direito inalienável à autodeterminação e independência. Tal atuação seria obstaculizada pela enorme diversidade do bloco, em termos ideológicos, políticos, econômicos, sociais e culturais. Países como $\mathrm{Cuba}^{7}$ teriam uma atuação mais contestatória em relação ao poderio americano e em algumas situações, defenderiam a União Soviética diante do MNAL, rejeitando a tese dos dois imperialismos e defendendo que a URSS, como país socialista e anti-imperialista, seria na verdade um aliado do Terceiro Mundo (Fernández 2003). Outros países lutavam justamente para obterem maior autonomia diante da União Soviética, como a Iugoslávia de Tito, por exemplo.

Desse modo, marcada por forte componente idealista, essa coalizão teve dificuldade em evoluir devido à heterogeneidade econômica e política en-

7 De I959 até I967, a prioridade da política externa cubana era estabilizar e consolidar a revolução. Mas já nessa fase há o suporte a guerrilhas na América Latina e a defesa de causas progressistas ao redor do mundo, o que o Fernández (2003) chama de exportação da revolução. Nesse período, Cuba é expulsa da OEA e isolada do resto do continente, e acaba buscando o apoio econômico e moral de Moscou, apesar das divergências sobre como deveria ser a estratégia revolucionária. Ou seja, esse não foi o período de maior sintonia entre Cuba e União Soviética, principalmente porque a União Soviética ficou desconfiada com a participação de Cuba no Movimento dos Não-Alinhados, por exemplo. Já no período de I968 até I974, Cuba e União Soviética tiveram uma maior aproximação, com o apoio de Cuba à invasão da Tchecoslováquia. Assim sendo, com o auxílio e proteção econômica e militar, Cuba fica livre para exercer um maior protagonismo internacional na década de I970 (Fernández 2003). 
tre seus membros, o que dificultava uma ação coletiva mais incisiva em prol do desenvolvimento (Soares de Lima \& Hirst 2009). Ademais, diversos países recém-independentes encontravam-se ainda atrelados à dominação indireta de países industrializados mais poderosos (a despeito da independência formal), o que dificultava a mobilização rumo a uma via autônoma de desenvolvimento (Linhares 2006).

Apesar disso, a demanda por acelerar o desenvolvimento econômico no Terceiro Mundo e, mais do que isso, fomentar um comércio mais equilibrado entre Norte e o Sul, foi amplamente defendida pelos países periféricos no período. Nesse sentido, a criação da Conferência das Nações Unidas sobre o Comércio e Desenvolvimento (UNCTAD) e o surgimento do G-77, em I964, representam a capacidade de influência e o peso político que os países em desenvolvimento passariam a exercer no âmbito da ONU, pressionando por uma nova ordem econômica internacional que fosse mais justa e igualitária. O objetivo do G-77 é, pois, fornecer os meios para que os países do Sul pudessem articular e promover seus interesses econômicos coletivos e melhorar a sua capacidade de negociação conjunta no sistema das Nações Unidas.

Na Declaração Conjunta do G-77 da Conferência de Genebra de I964 foram destacados os problemas do déficit comercial em países em desenvolvimento e a deterioração dos termos de troca (Grupo dos 77 I964). Na Carta de Argélia, de 1967 ressaltou-se a necessidade de um novo acordo global sobre commodities, dado que os países desenvolvidos aumentaram o grau de proteção sobre diversos produtos agrícolas (enquanto o preço médio dos produtos primários exportados por países em desenvolvimento diminuiu $7 \%$ desde I958, os preços de exportação dos mesmos produtos nos países centrais aumentaram ı०\%). Segundo a Carta,

Com algumas notáveis exceções, os termos e condições de financiamento do desenvolvimento estão se tornando cada vez mais onerosos; a proporção de subvenções está em declínio; as taxas de juros estão aumentando; os períodos de reembolso estão encurtando e empréstimos ao desenvolvimento estão se tornando cada vez mais condicionados. Práticas discriminatórias e disposições em matéria de transporte e aumento das taxas de frete agravaram ainda mais a situação da balança de pagamentos, prejudicando o esforço para promover as exportações nos países em desenvolvimento (Grupo dos 77 I967).

A Carta de Argel simbolizou, desse modo, a primeira reivindicação conjunta e organizada sobre temas que seriam retomados e ainda estariam em discussão no século XXI, como a questão das barreiras tarifárias dos países desenvolvidos sobre produtos agrícolas. A Carta assinala que o G-77 parte 
do pressuposto de que "em um mundo cada vez mais interdependente, a paz, o progresso e a liberdade são comuns e indivisíveis" e, "por conseguinte, o desenvolvimento dos países em desenvolvimento irá beneficiar os países desenvolvidos também" (Grupo dos 77 I964). Assim sendo, há uma clara noção de que a responsabilidade para o desenvolvimento dos países periféricos repousa também sobre os países desenvolvidos, sendo uma ação coletiva global. A Carta também ressalta que os países em desenvolvimento devem reduzir as desigualdades entre eles, visto que dentro do próprio Terceiro Mundo existem países mais industrializados que outros.

Nesse âmbito, vale destacar que a Conferência do G-77 em Argel foi precedida, um ano antes, por uma conferência que marcaria o início de uma solidariedade que inclui além dos continentes asiáticos e africanos, o continente latino-americano. Trata-se da Conferência Trilateral de Havana, de I966, que fundou a Organização de Solidariedade dos Povos da África, Ásia e América Latina (OSPAAAL). Essa conferência teria um caráter de solidariedade revolucionária, condenando o imperialismo, o colonialismo e o neocolonialismo. Enquanto o G-77 teria um caráter vinculado à ONU e colocaria no centro do debate o desenvolvimento econômico, a Conferência Trilateral traria a denúncia de problemas sociais, como a fome, a pobreza e a miséria no Terceiro Mundo, e possuía um caráter normativo no sentido de fomentar e instrumentalizar as lutas por libertação ao redor do mundo.

Por conseguinte, o que se observa nessa fase inicial de desenvolvimento das relações sul-sul (I955-1966) é uma tentativa de primeiro consolidar a descolonização dos povos afro-asiáticos através das lutas de libertação nacional e, concomitantemente, apresentar uma agenda de desenvolvimento própria do Terceiro Mundo, colocando pela primeira vez em organizações internacionais pautas como a pobreza, a miséria, a fome, o racismo e a desigualdade econômica. Nessa época, surgem mecanismos multilaterais autônomos ligando a periferia do sistema mundial, como a Conferência de Bandung, o Movimento dos Não-Alinhados e a Trilateral de Havana, que serviriam para instrumentalizar as estratégias de política externa dos países do Terceiro Mundo durante a Guerra Fria, fornecendo princípios basilares e valores que vão além do caráter econômico, possuindo uma dimensão social e política. Ao mesmo tempo, mecanismos como a UNCTAD e o G-77 reforçam as disparidades no comércio internacional e pressionam por uma agenda de desenvolvimento que leve em conta o caráter agroexportador dos países do Terceiro Mundo e fortaleça a sua industrialização.

Vale ressaltar que a emergência dessas agendas de desenvolvimento está fortemente vinculada às promessas que o sistema-mundo sob hegemonia americana apresentava aos países em desenvolvimento, conformando 
a "ideologia do desenvolvimento" (Wallerstein I992; Amin 20I0). E, sendo assim, a Pax Americana, conforme mencionamos, já nasce com um caráter de instabilidade, muito em parte devido ao surgimento de uma periferia mais autônoma. Segundo Arrighi (I996, 293), "prometeram-se o direito à autodeterminação e o desenvolvimento (isto é, ajuda para se equipararem aos padrões de riqueza e bem-estar criados pelas nações ocidentais)" mas como consequência "gerou expectativas que ameaçaram seriamente a estabilidade da hegemonia norte-americana e acabaram por precipitar sua crise". Diante disso, a emergência da periferia possui implicações sistêmicas e, nesse momento inicial, iria contribuir para a crise da hegemonia americana e o início de uma reação conservadora que atingiria seu auge na década de I980.

\section{De Lusaka à Buenos Aires (1967-1978): A Nova Ordem Econômica Internacional e a emergência da Cooperação Sul-Sul}

A fase que inicia na virada da década de I960 para a década de I970 marca o início do declínio da hegemonia norte-americana com a Guerra do Vietnã e o surgimento de competidores no nível econômico, como Europa e Japão, que se reergueram justamente através da Cooperação Norte-Norte desenvolvida pelos EUA no pós-guerra. Segundo Wallerstein (I992), enquanto o período que vai de I945 até I967 é marcado por uma dominação política e militar e uma liderança cultural incontestável dos EUA, o período que se segue é de reações sistêmicas à sua hegemonia, reações que se diferem dos clássicos movimentos anti-sistêmicos (nacionalismo e socialismo), e estão ligados a revolução mundial de I968, as guerras na Argélia e Vietnã e a emergência do Terceiro Mundo. Ademais, no âmbito cultural, a própria ideologia do desenvolvimento vai se erodindo, pois os novos países descolonizados se dão conta que a independência nacional não significou a libertação total dos laços econômicos e, por conseguinte, acabam denunciando com mais vigor as desigualdades sistêmicas.

Verifica-se, então, a partir de I967, o fortalecimento de uma agenda de desenvolvimento econômico que já havia sido lançada em meados de ig60 com a UNCTAD e o G-77. O próprio Movimento dos Não-Alinhados passaria a ganhar uma conotação econômica. Conforme ressalta Amin (20Io, n/p), “o Movimento dos Não-Alinhados [...] iria deslizar progressivamente de posições de uma frente de solidariedade política centrada no apoio às lutas de libertação e na recusa de pactos militares às de um 'sindicato de reivindicações econômicas em relação ao Norte’”. Ademais, tal período marca o início dos primeiros diálogos na ONU para instrumentalizar as relações sul-sul, e se intensifica a ideia de cooperação técnica entre países em desenvolvimento. 
Geograficamente, tem-se a inclusão dos países latino-americanos à agenda do Sul, carregando consigo a agenda econômica desenvolvida pela CEPAL na década de I950, com a denúncia sobre a deterioração dos termos de troca dos países da região.

O contexto econômico de fins da década de ig60, vale mencionar, é de declínio da participação dos países em desenvolvimento nas exportações do comércio mundial de um terço em i950 para um sexto em I969. Além disso, pesa o declínio dos fluxos financeiros em termos de percentagem do Produto Nacional Bruto (PNB) dos países desenvolvidos para os países em desenvolvimento e o aumento dos fluxos financeiros de países em desenvolvimento para os países desenvolvidos por meio de pagamentos de dívidas, dividendos, royalties e serviços financeiros e comerciais. A pobreza das nações em desenvolvimento é evidenciada como um problema crítico, dentro de um contexto econômico mundial desigual herdado do passado colonial. Nesse sentido, a ocupação de partes dos territórios dos países em desenvolvimento pelas antigas metrópoles ou governos minoritários priva esses grupos de seus recursos naturais e constitui um obstáculo ao seu desenvolvimento.

Diante desse cenário, a Conferência de Lusaka, de I970, trouxe consigo o princípio de autossuficiência coletiva, ou seja, a ideia de que os países periféricos não deveriam esperar pela benevolência dos países ricos para que uma nova ordem internacional surja. Isso significaria que os países do Terceiro Mundo seriam responsáveis pelo próprio desenvolvimento, com "maior controle de seus recursos naturais, busca do desenvolvimento científico e tecnológico próprio, melhorias em seus sistemas educacionais, assim como medidas externas (maior cooperação econômica e técnica entre estes países, associações e incremento de intercâmbio comercial, etc.)" (Pino 20I4, I64).

Além da agenda econômica, em Lusaka também fora reforçada a necessidade: a) de tomar medidas eficazes e concretas contra todas as forças que violem a independência e a integridade territorial dos países não-alinhados; b) de prosseguir os esforços para a dissolução de grandes alianças militares, em circunstâncias que garantam a segurança de todos os Estados e povos; c) de afirmar o direito de todos os países a participarem nas relações internacionais em pé de igualdade, sendo imperativa a democratização das relações internacionais; d) de oferecer apoio ao desarmamento; e) de intensificar os esforços conjuntos para a liquidação do colonialismo e da discriminação racial (para esse fim, reiteram o seu apoio moral, político e material possível máximo para movimentos de libertação nacional) e; f) de prosseguirem os seus esforços no sentido de fortalecer o papel e a eficácia da Organização das Nações Unidas, bem como promover a universalidade da ONU, garantindo, por exemplo, à República Popular da China seu lugar de direito na organização, e a admissão 
de outros países, incluindo os que estão divididos (Movimento dos Não-Alinhados 20I5).

A Conferência de Lusaka, desse modo, materializa a ideia de que os países periféricos agora são responsáveis por seu próprio desenvolvimento, representando uma tomada de consciência das novas nações emergentes em relação aos seus rumos, não deixando, porém, de denunciar as desigualdades e injustiças na economia internacional. Em Lusaka se exige especialmente dos países membros uma utilização justa dos recursos naturais, que promova bem-estar na sociedade, emprego, renda e oportunidades sociais. Em I973, os países Não-Alinhados apresentam a Carta de Argel, se posicionando a favor do fim dos conflitos em diversas regiões do Terceiro Mundo. Para o Oriente Médio, a Carta reclama o cumprimento de resoluções da ONU que obrigam a Israel a evacuar os territórios ocupados em I9 67; condena a apropriação ilegítima do território palestino e clama pelo restabelecimento dos direitos do povo palestino. Com relação ao Sudeste Asiático, a Carta celebra os Acordos de Paris e os considera como uma vitória do povo do Vietnã; condena a ingerência norte-americana na Indochina; convida os países a ajudar na reconstrução do Vietnã; condena a invasão do Camboja, afirmando que o seu governo legal é formado pelo príncipe Norodom Sihanouk; apoia a ação de reunificação pacífica empreendida pelo povo coreano e a retirada de tropas estrangeiras da Coreia do Sul. Para a África, a Carta de Argel condena os regimes racistas que contam com apoio econômico, político e militar de países do Ocidente; denuncia a ajuda desigual que os países da África recebem por parte de certos países da OTAN; afirma que apenas a luta armada colocará fim à dominação colonial na região. Para a América Latina, a Carta condena a existência de dominação colonial na região e presta apoio à luta do povo do Porto Rico por sua liberdade e independência; além disso, exige que os EUA retirem suas forças militares do território cubano, panamenho e porto-riquenho e os devolva a seus legítimos donos.

Durante a Conferência de Argel, de I973, os países-membros enviaram uma solicitação ao secretário-geral da ONU para convocar uma sessão extraordinária na Assembleia Geral com o intuito de debater problemas concernentes ao comércio de matérias-primas e ao desenvolvimento. Um ano mais tarde, são firmadas a Declaração de Estabelecimento de uma Nova Ordem Econômica Mundial (Resolução 3.20I de I974), de modo a fomentar o comprometimento dos países membros em distribuir de forma mais justa os recursos naturais, humanos e econômicos, determinando o aumento de assistência para países em desenvolvimento, a promoção de condições favoráveis na transferência de recursos financeiros para países periféricos, bem como a soberania dos Estados no gerenciamento de recursos naturais e atividades 
econômicas. Paralelamente, foi assinado um Plano de Ação para uma Nova Ordem Econômica Mundial (Resolução 3.202), buscando instrumentalizar e orientar as práticas dos países, incluindo, em um de seus itens, a necessidade de reforma no Sistema Monetário Internacional (FMI). Em I974, também é elaborada a Carta de Direitos e Deveres Econômicos dos Estados (Resolução 3.28I, de dezembro de i974).

Nesse sentido, a Nova Ordem Econômica Internacional consistia em um conjunto de propostas (sobretudo de países do Terceiro Mundo) com o objetivo de expandir as instituições da ONU, constituindo um desafio ao direito internacional vigente à época (RAJAGOPAL, 2003). No que tange às práticas de cooperação, na década de 1970 são incrementadas as críticas ao modelo de assistência Norte-Sul e começa a se desenvolver teoricamente o conceito de Cooperação Sul-Sul, operacionalizado e regulado em diversos organismos internacionais, mas principalmente na ONU: em I972 é criado um grupo de trabalho sobre cooperação técnica entre países em desenvolvimento (CTPD) e, em I974, é formada a Unidade Especial de Cooperação Técnica entre Países em Desenvolvimento, vinculada ao Programa das Nações Unidas para o Desenvolvimento (PNUD), que acabou se tornando "ponto focal da Cooperação Sul-Sul no âmbito do sistema da organização, ao promover, gerir e coordenar essa cooperação e estabelecer o elo entre o PNUD e o G-77" (Pino 20I4, 65).

É com a Conferência de Buenos Aires, de I978, que se tenta, pela primeira vez, organizar e institucionalizar a prática da Cooperação Sul-Sul no âmbito da ONU. O Plano de Ação de Buenos Aires, resultado das discussões realizadas nessa conferência, desenvolve o conceito de cooperação técnica baseado na reciprocidade e horizontalidade, instrumentalizada através do intercâmbio de conhecimentos, informações, tecnologias e técnicas de gestão em políticas públicas nas áreas de educação, saúde, agricultura, entre outras. O ano de 1978 é um marco na Cooperação Sul-Sul pois pela primeira vez foram elaborados conceitos e princípios de maneira conjunta entre os países periféricos, colocando em destaque a ideia de que a prática social de um país pode ser replicada em outros países e gerar desenvolvimento. Tratava-se, em suma, "da promoção da autossuficiência dos países em desenvolvimento e o fortalecimento de suas capacidades para analisar, identificar e resolver seus principais problemas" (PINO, 20I4, p. 66). No sentido de instrumentalizar, organizar e promover a prática da Cooperação Sul-Sul, foi criado o Comitê de Alto Nível para a Cooperação Sul-Sul (órgão subsidiário da Assembleia Geral da ONU), que se tornou uma importante entidade normativa em matéria de cooperação entre países em desenvolvimento.

Diante desse panorama sobre a evolução das relações entre a periferia no período, o que se observa no nível sistêmico é que a Cooperação Sul-Sul 
passam a ser cada vez mais institucionalizada no âmbito da ONU, enquanto que os mecanismos autônomos de atuação, como o Movimento dos Não-Alinhados, vão perdendo importância e se tornando cada vez mais foros de diálogos e de manifestações ideológicas. Em termos de coordenação da ação coletiva, ela é enfraquecida quando o número de membros é alto e, para se tornar efetiva, necessita que alguns membros se disponham a arcar com custos políticos e econômicos de forma desproporcional em prol da coesão do grupo. Diante disso, o momento inicial das relações sul-sul é marcado por desafios à coordenação da ação coletiva, mas também é caracterizado por uma maior ousadia dos países do Sul na reivindicação de suas demandas, após a descolonização da grande maioria dos países afro-asiáticos. A progressiva industrialização da periferia, segundo Amin (I997), enfraquece a polarização típica do sistema mundial capitalista, e contribui, no período analisado, para o declínio da hegemonia estadunidense, que passa a ser cada vez mais contestada sob a forma de movimentos antissistêmicos e a irrupção de regimes marxistas-leninistas no Terceiro Mundo.

\section{Conclusões}

O período que vai de I955 a I978 marca a consolidação e o estabelecimento de uma agenda da periferia e a inserção internacional de um terceiro bloco na ordem internacional da Guerra Fria, contribuindo para o declínio da hegemonia norte-americana. Esse período se subdivide em duas fases principais: enquanto que de I955 a I967 tem-se as lutas pela libertação nacional na África e Ásia, o não-alinhamento e o desenvolvimento dos primeiros arranjos ligando a periferia global como a Conferência de Bandung, o Movimento dos Não-Alinhados, a UNCTAD e o G-77; de I967 a I978, as demandas se concentram na luta por uma nova ordem econômica internacional e na necessidade de desenvolver e institucionalizar a Cooperação Sul-Sul. Como consequência desse momento inicial, se observa na década de i980 e i990 uma espécie de reação conservadora, que serviria para obstaculizar a Cooperação Sul-Sul e inserir a periferia na lógica Norte-Sul de cooperação, com o avanço dos princípios do neoliberalismo, que exigiam ajuste fiscal aos governos de países em desenvolvimento como condição para receber cooperação.

Nesse sentido, a lógica da periferia na década de i980 e início da década de I990 é de refluxo da agenda social de desenvolvimento e de arrefecimento dos arranjos típicos do contexto da Guerra Fria, como o Movimento dos Não-Alinhados. Porém, a partir de meados da década de I990, verifica-se um novo impulso na Cooperação Sul-Sul, reorganizado sob a nova lógica de poder que se observa com o fim da Guerra Fria, desta vez com a emergên- 
cia de uma semiperiferia ativa. Durante o período analisado neste artigo, de I955 a I978, verificou-se que os países da periferia tinham dificuldade em lidar com a lógica da ação coletiva, dada a heterogeneidade interna dos seus membros. Os países mais poderosos do Terceiro Mundo, como China, Índia e Brasil, atuavam dentro da lógica de poder da Guerra Fria, muitas vezes distanciando-se da ideia de arcar com os custos da liderança do Terceiro Mundo. Assim sendo, não houve uma consonância plena entre a atuação externa da periferia e a da semiperiferia. A China, especialmente, ao estabelecer aliança com os EUA na década de I970 contribuíra para contrabalancear o poderio soviético, entrando dentro da lógica da tripolaridade estratégica desenvolvida por Kissinger e Nixon. O Brasil, a despeito de viver alguns momentos de um paradigma mais globalista e de diversificação das parcerias com outros continentes, em boa parte desse período se viu alinhado na lógica norte-americana da doutrina das fronteiras ideológicas, afastando o perigo comunista dos países latino-americanos. A Índia, por sua vez, acabou se aproximando da União Soviética, sobretudo após o apoio norte-americano ao Paquistão, e acabaria formando um eixo desde Aden até o Estreito de Málaga, contrapondo-se ao eixo sino-americano.

Nesse sentido, verifica-se que o momento inicial de emergência da periferia a partir da Conferência de Bandung contou com a participação moderada das potências intermediárias, que procuraram se inserir dentro da lógica de poder da Guerra Fria, buscando extrair vantagens da aliança com uma das superpotências. Entretanto, no momento atual da Cooperação Sul-Sul, com o fim da Guerra Fria, os países da semiperiferia passam a atuar cada vez mais sintonizados com a periferia e entre si, conformando blocos como o BRICS e o IBAS. Esses novos arranjos apresentam caráter reformista da ordem internacional e buscam novas soluções e formas de cooperação para lidar com problemas concernentes ao desenvolvimento, tão caro aos países da periferia. A criação do Banco dos BRICS e a cooperação na área militar sinalizam um crescente protagonismo desse grupo de países, que tem se portado como porta-vozes dos países em desenvolvimento através dos seus modelos de cooperação diferenciados da lógica Norte-Sul que imperava nas décadas de ig80 e I990.

A China tem baseado sua cooperação nos princípios de igualdade e benefício mútuo, ausência de condicionalidades políticas e econômicas e um componente de críticas implícitas às supostas segundas intenções da Cooperação Norte-Sul. Mais recentemente, tem se dedicado à cooperação econômica e a construção de infraestrutura na África, em uma espécie de disputa geoeconômica por espaço com as velhas potências inseridas no continente. A Índia, por sua vez, tem contribuído com a inserção de produtos intensivos em tecno- 
logia e produtos farmacêuticos a custo baixo no continente africano e sua cooperação é destacada nas áreas de Tecnologia da Informação, energia nuclear, tecnologia aeroespacial e energias renováveis. E o Brasil, por sua vez, tem investido no alto perfil diplomático e na modalidade técnica da cooperação, sobretudo com a América Latina e países da África Lusófona, com o compartilhamento da expertise de técnicas e tecnologias sociais dos órgãos do governo e empresas estatais brasileiras como o Ministério do Desenvolvimento Social (MDS), Ministério da Saúde (MS), EMBRAPA, FIOCRUZ, entre outras. Nesse sentido, a periferia no Pós-Guerra Fria possui uma gama mais ampla de opções estratégicas, o que indica que uma maior multipolaridade tem trazido benefícios para a periferia, trazendo novas alternativas de alinhamento e cooperação. Isso não significa que as relações sul-sul são expressão exclusiva da solidariedade e do altruísmo, estando também sujeita aos interesses dos Estados Nacionais pensados como unidades autônomas.

No entanto, a história ensinou que a emergência da periferia pode trazer consigo uma espécie de reação conservadora, conforme observada nas décadas de I980 e I990. Nesse sentido, importa observar as reações sistêmicas das potências tradicionais à emergência dos novos polos de poder, sobretudo as reações aos BRICS. Outro ponto a atentar é que a situação da periferia depende fortemente de como atua a semiperiferia, que pode se render à lógica da alta política e servir como peça de xadrez no jogo da superpotência. A construção da hegemonia, como bem aponta Arrighi (I996), possui um componente de liderança, ou seja, de fazer da vontade individual do país uma vantagem geral. Desse modo, as opções estratégicas dos países da semiperiferia devem considerar os seus impactos de longo prazo sobre a periferia, de modo a construir confiança mútua. Os BRICS, por conseguinte, devem construir mecanismos institucionais que deem mais voz à periferia, e não apenas buscar a concertação entre si. Assim como os BRICS apresentaram um modelo alternativo ao monopólio financeiro e monetário do Sistema de Bretton Woods, no campo político deveriam avançar discussões que levem em consideração um sistema alternativo à ONU, um sistema que seja mais democrático e leve em conta o peso da periferia, tanto em termos de unidades políticas em relação ao resto do mundo quanto em termos de população e participação na economia mundial.

Não se trata apenas de buscar soluções no nível institucional e internacional, como a teoria neoliberal das Relações Internacionais propõe, mas de pensar de forma realista em estratégias que coadunem os interesses da semiperiferia e da periferia e contribuam para um maior equilíbrio e desconcentração do poder mundial. Portanto, no contexto atual, de crise de hegemonia, importa a disputa de ideias, valores e princípios, atrelada diretamente à 
capacidade da semiperiferia produzir alternativas e soluções para o desenvolvimento. A periferia (sobretudo a África) pode se beneficiar da disputa geoeconômica entre centro e semiperiferia, na medida em que se proliferam alternativas de investimento e cooperação. Entretanto, cabe à periferia estabelecer suas prioridades e formas de atuação, podendo resgatar ou não a estratégia de concertação da época de Bandung e do Movimento dos Não-Alinhados.

\section{REFERÊNCIAS}

Amin, Samir. I997. Los desafios de la mundialización. Madrid: Siglo Veintuone Editores. . 20I0. $50^{\circ}$ Aniversário da Conferência da Bandung. Entrevista com Samir Amin conduzido por Rémy Herrera. In: Marxismo Revolucionário Atual, Acesso em 09. jun.20I5. http://resistir.info/samir/bandung_ port.html.

Arrighi, Giovanni. 1996. O longo século XX: dinheiro, poder e as origens do nosso tempo. Rio de Janeiro: Contraponto.

Fernández, Damian. 2003. Cuba: talking big, actin bigger. In: Mora, Frank \& Hey, Jeanne (eds). Latin American and Caribbean foreign policy. Boulder: Rowman \&Littelfiield.

Fraser, Nancy. 2007. Reconhecimento sem ética? São Paulo: Lua Nova, 70: IOII38.

Guitard, Odette. I962. Bandung y el despertar de los pueblos coloniales. Buenos Aires: Editorial Universitária de Buenos Aires.

Grupo dos 77. 1964. Joint Declaration of the Group of 77. Genebra, I5 de junho de I964. Acesso em Io.jun.20I5. http://www.g77.org/doc/Joint\%20 Declaration.html.

Linhares, Maria Yedda Leite. 2005. “Descolonização e lutas de libertação nacional”. In: Reis Filho, Daniel Aarão; Ferreira, Jorge; Zenha, Celeste. (orgs.). O século XX: o tempo das crises, revoluções, fascismos e guerras. Rio de Janeiro: Civilização Brasileira (2): 35-64.

Movimento dos Não-Alinhados. 2015. History, Evolution, Purposes and Principles. Acesso em 09.jun.20I5. http://namiran.org/backgroundgeneral/.

Olson, Mancur. 1965. The Logic of Collective Action. Cambridge,Mass.: Harvard University Press.

Osterhammel, Jürgen e Niels Peterson. 2005. Globalization: a short history. Princeton/Oxford: Princeton University Press. 
Pino, Bruno Ayllón. 20I4. Evolução histórica da Cooperação Sul-Sul. In: Repensando a cooperação internacional para o desenvolvimento. Organizador: André de Mello e Souza. Brasília: Ipea.

Rajagopal, Balakrishnan. 2003. International Law from Below - Development, Social Movements and Third World Risistence. Cambridge: Cambridge University Press.

Soares de Lima, Maria Regina; Hirst, Mônica. 2009. Brasil, Índia e África do Sul: Desafios e oportunidades para novas parcerias. São Paulo: IUPERJ.

Visentini, Paulo Fagundes. 20II. As Relações diplomáticas da Ásia: articulações regionais e afirmação mundial (uma perspectiva brasileira). Belo Horizonte: Fino Traço. ISBN: 978-85-8054-042-0.

Wallerstein, Immanuel. I992. Geopolitics and geoculture. Cambridge: Cambridge University Press.

\section{RESUMO}

O objetivo deste artigo é analisar a fase inicial de desenvolvimento das relações sul-sul e da emergência da periferia, considerando que a Cooperação Sul-Sul tal qual a conhecemos hoje deu seus passos iniciais no contexto do início da Guerra Fria, com a descolonização de países afro-asiáticos e a formação dos primeiros arranjos ligando a periferia global, como a Conferência de Bandung, a criação do Movimento dos Não-Alinhados, do G-77 e da UNCTAD. Nessa primeira fase, o objetivo era garantir a descolonização e o não-alinhamento. A partir da década de I970, países da América Latina e África Subsaariana também passam a se envolver de forma crescente com a agenda do Terceiro Mundo, em uma tentativa de fomentar a cooperação política, econômica e técnica entre países em desenvolvimento. A Cooperação Sul-Sul passa a ser progressivamente institucionalizada no âmbito da ONU, sobretudo com a Conferência de Buenos Aires de 1978.

\section{PALAVRAS-CHAVE}

Periferia; Cooperação Sul-Sul; Conferência de Bandung; Conferência de Buenos Aires; BRICS.

Recebido em 8 de julho de 2015. Aprovado em 10 de agosto de 2015. 


\title{
POLÍTICA EXTERNA REGIONAL DE ANGOLA: MUDANÇAS FRENTE À ORDEM SISTÊMICA
} (1975-2010)

\author{
Igor Castellano da Silva ${ }^{1}$
}

\section{INTRODUC̣ÃO}

As Relações Internacionais têm se preocupado crescentemente com o papel de regiões na distribuição de poder global e de sistemas regionais como unidade de análise que possibilita progressos teóricos e empíricos na disciplina. Regiões do Sul global, inclusive a África, têm sido uma das partes mais importantes desse processo, o que desperta atenções da política externa e comunidade acadêmica brasileira. Contudo, a compreensão sobre a evolução das dinâmicas de sistemas regionais do Sul deixa espaço para avanços importantes, dentre eles uma interpretação mais clara sobre como e por que sistemas regionais se transformam e qual é o papel da política externa de unidades sistêmicas nesse processo. Estudos sobre regiões têm focado quase exclusivamente na análise sobre potências regionais e muito pouco na posição das potências secundárias sobre ordens vigentes. Talvez essas dificuldades analíticas (escassez de uma visão bottom-up das relações regionais) impactem inclusive nas dificuldades de avanço de processos de integração no Sul global, que muitas vezes carecem por representar interesses de potências menores. O caso da África Austral segue esse padrão e as análises disponíveis envolvem foco predominante na África do Sul, com escassa compreensão sobre as características e causas do comportamento de outras unidades sistêmicas. Apesar da importância para as relações regionais e continentais, pouco se

I Professor de Relações Internacionais da Universidade Federal de Santa Maria (UFSM) e coordenador do Grupo de Estudos em Capacidade Estatal, Segurança e Defesa (GECAP). Doutor em Estudos Estratégicos Internacionais, mestre em Ciência Política e bacharel em Relações Internacionais pela Universidade Federal do Rio Grande do Sul (UFRGS). É pesquisador associado ao Centro Brasileiro de Estudos Africanos (CEBRAFRICA) e ao Centro de Estudos Internacionais sobre Governo (CEGOV) da UFRGS.

E-mail: igor.castellano@gmail.com 
sabe sobre a política externa regional de países como Angola, uma potência secundária de peso, cujas ações impactam significativamente nas dinâmicas da região.

Nesse contexto, a pesquisa procura responder como evoluiu a política externa regional angolana frente às transformações no sistema regional a partir de 1975 (ano de sua independência). Mais especificamente, o que explica a política externa angolana frente às ordens regionais estabelecidas em I975-88 e I989-20ıo? Avaliar o papel de Angola nas relações internacionais da África Austral é fundamental para se compreender a magnitude dos desafios enfrentados pela ordem regional centralizada na África do Sul. Entre i975 e I988, Angola foi a potência secundária mais ameaçadora da região, dada a sua postura revolucionária frente à ordem conservadora vigente e a sua capacidade de atrair forças extrarregionais para as disputas envolvendo seu conflito doméstico. Após I989, Angola continuou sendo um agente importante na política regional, principalmente na área securitária, e incrementou significativamente suas capacidades estatais desde 2002, o que gerou impactos importantes em sua política externa.

O argumento aqui sustentado é que a política externa regional de potências regionais ou secundárias pode ser compreendida pela posição do país a favor da continuidade ou mudança da ordem sistêmica e seu ímpeto de ação para realização desse projeto. A política externa regional, por sua vez, é derivada de um processo complexo de construção do Estado em que elites definidoras de política externa (EDPEs) buscarão concretizar seus projetos políticos e responderão a pressões domésticas e externas de acordo com as capacidades estatais disponíveis. Entre I975-88 as EDPEs angolanas buscaram implantar um projeto político desenvolvimentista de fortalecimento do Estado (embora sem sucesso) e de mudança da ordem regional conservadora caracterizada pela dominância da África do Sul. As altas pressões internas e externas foram respondidas com grande ímpeto de ação, principalmente proveniente da disponibilidade de recursos naturais (petróleo) e apoio externo (URSS e Cuba). Após um breve interregno de acomodação de pressões externas e tentativas de diálogo interno, o período de I989-2010 observou uma renovada busca impetuosa de mudança da nova ordem regional liberal também centralizada pela África do Sul e de superação das pressões internas e externas mediante o agora real incremento das capacidades estatais. Após a redução das pressões em ambas as frentes, Angola adotou uma política externa pouco impetuosa, comedida e menos interessada com grandes mudanças na ordem regional. ${ }^{2}$

2 O modelo analítico adotado pelo estudo ressalta o papel da construção do Estado como fator de mudança no sistema regional. Uma das formas pela qual o processo de construção do Estado impacta no sistema regional é mediante a política externa das unidades sistêmicas. Estados

140 Austral: Revista Brasileira de Estratégia e Relações Internacionais v.4, n.7, Jan./Jun. 2015 
A primeira seção do artigo aborda a política externa de Angola frente à ordem regional entre 1975 e I988, destacando o processo de construção do Estado (contexto, capacidades estatais e relações Estado-sociedade) e a avaliação da política externa sob aspectos da sua formação (projeto político da elite definidora de política externa e sua segurança frente a pressões domésticas e externas) e execução (posição em direção ao status quo e ímpeto de ação no sistema). A segunda seção faz o mesmo para o período de 1989 e 2010 . A conclusão traz a síntese dos resultados, os quais compõem um estudo mais amplo envolvendo política externa no sistema regional da África Austral (Castellano da Silva 20I5).

\section{ESTADO, ELITES E POLIITICA EXTERNA EM ANGOLA (1975-1988)}

A ordem do sistema regional da África Austral, ao passo que se formava desde início do século XX, passou a ser gradualmente centrada na África do Sul e a sustentar-se em quatro pilares básicos, mantidos até o declínio do apartheid em fins da década de $1980 .{ }^{3}$ No pilar político, a ordem conservadora baseava-se na herança do sistema colonial no status quo territorial e no princípio da defesa da soberania pelos meios do Estado, mediante uma governança centralizada nos Estados mais fortes. Na área econômica o conservadorismo (protecionismo e mercantilismo) combinava-se com o liberalismo, já que este favorecia a centralidade da posição da África do Sul. Essa centralidade sustentava-se, mediante eixos logísticos (infraestruturais) e financeiros, e relações comercialistas centradas no polo econômico da Rand. No pilar social, a ordem conservadora baseava-se na dominação sociocultural de elites vinculadas ao

agem frente a ordens sistêmicas estabelecidas (instituições formais e informais que sustentam o regramento de comportamentos e a distribuição de benefícios no sistema) de acordo com os interesses de suas EDPEs e as pressões (ameaças e assimetria de poder) que elas experimentam interna e externamente. Embora a disponibilidade de recursos naturais e de apoio externo auxilie nas capacidades de ação de alguns países, as capacidades estatais efetivas disponíveis às elites governantes no âmbito da coerção, capital e legitimidade definirão a sustentabilidade da ação externa e as condições de extração de recursos disponíveis na sociedade (Castellano da Silva 20I5).

3 Para fins analíticos, ordens sistêmicas podem ser avaliadas nos eixos político, econômico, social e securitário. A base política da ordem envolve os valores, as normas e instituições que regem a distribuição territorial do sistema, os princípios que regem as relações diplomáticas e a garantia da sobrevivência política dos Estados. A base econômica diz repeitos a valores, normas e instituições que regem o conteúdo das relações econômicas (princípios do comércio e do fluxo de bens e serviços). A base social indica valores, normas e instituições vinculadas ao conteúdo das relações sociais e à prioridade estabelecida para diferentes tipos de direitos das populações da região. A base securitária da ordem relaciona-se a valores, normas e instituições que regulam a organização e os comportamentos sobre o conteúdo da segurança. 
projeto colonial e em sistemas discriminatórios e segregacionistas. Na esfera da segurança, mantinha-se o primado da segurança nacional, com atenção especial aos desafios da segurança produzidos pelos movimentos de libertação nacional. A independência de Angola e de outros países revisionistas regionais representou a crescente contestação da ordem centrada na África do Sul. Entretanto, os interesses e as condições de ações desses novos Estados seriam determinados pelo seu processo particular de construção estatal.

\section{Construção do Estado em Angola (1975-1988)}

Angola, anteriormente a joia da colônia portuguesa (Birmingham 2002, I37), tornava-se em I975 o centro da geopolítica africana. A guerra que sucedeu ao Acordo de Alvor (janeiro de 1975) se prolongou por quase trinta anos após a independência (em novembro de I975) e tornou-se uma espiral de conflitos que, pelo menos até i 989 , centralizou a disputa regional e global no continente. Angola foi palco dos interesses estratégicos de potências intermediárias da região (África do Sul e Zaire) e de fora dela (Cuba), bem como de potência globais (EUA, URSS e China). Essa relevância global foi, todavia, submetida a complexas dinâmicas locais e regionais e perdeu impulso com o fim da década de i980. Seu potencial econômico 4 e posição geográfica estratégica, com ampla área costeira e conexões viárias que integram o interior, contribuíram para a contínua relevância de Angola na geopolítica regional. Além disso, a complexidade da composição dos movimentos de libertação nacional e a crescente inserção e suporte de atores regionais e globais garantiu destaque de sua posição. Os movimentos surgiram da politização de identidades étnicas predominantes em Angola (kongo, mbundu e ovimbundu) ${ }^{5}$

4 O país possui reservas significativas de petróleo, gás, diamantes e água. Seu clima e relevo possibilita grande fertilidade agrícola, representada na produção cafeeira.

5 A diferenciação étnica foi incrementada durante a colonização, resultando em três grupos principais. Os kongo compartilhavam a ancestralidade do reino do Kongo e habitavam a fronteira com o Zaire (inclusive adotaram amplamente o uso do francês). Os mbundu tiveram maior interação com os portugueses e assimilação cultural. Eram associados a populações mestiças urbanas modernizadas e ocidentalizadas. Já os ovimbundu eram originários dos planaltos centrais da onde foram removidos para servirem de mão-de-obra em plantações de café no norte, o que incrementou o potencial de conflito com os outros grupos. Como a socialização era fundamentada nesses laços, a identidade e a mobilização políticas tiveram grande conexão com essas divisões. O Movimento Popular de Libertação de Angola (MPLA), criado em I956, teve base de apoio nos mbundu ( $20 \%$ da população, predominante no entorno da capital); o Frente Nacional de Libertação de Angola (FNLA), surgido em I962, era vinculado à população kongo (predominante no norte); e a União Nacional para a Independência Total de Angola (UNITA), baseou-se no suporte da população ovimbundu (40\% da população, predomina no centro-sul) (Bauer and Taylor 2005, I45).

142 Austral: Revista Brasileira de Estratégia e Relações Internacionais v.4, n.7, Jan./Jun. 2015 
e assumiram de forma diversa aspectos ideológicos seculares. Entretanto, sua identificação com ideologias políticas nacionalistas mais amplas foi crescente, principalmente da parte do Movimento Popular de Libertação de Angola (MPLA). ${ }^{6}$ Esse movimento assumiu a ideologia marxista-leninista nacionalista e angariou apoio de URSS, Cuba e Alemanha Oriental, desde a década de I960, o que foi incrementado com a aproximação da independência (Shubin 2008 , I5). Seus rivais, por seu turno, permaneceram vinculados a identidades particularistas e angariaram apoio de EUA e China. ${ }^{7}$

A vitória do MPLA na guerra de libertação após a Revolução dos Cravos em Portugal (I974) e o rompimento do Acordo de Alvor (estabelecia um governo de transição) com a retirada relâmpago e violenta dos portugueses, levou à construção de um Estado revolucionário. Finda a era de independências pacíficas (década de I960), a promessa da ascensão dos movimentos de libertação nacional que incrementaram a sua atuação na década de 1970, em Angola, Moçambique, Zimbábue, Guiné-Bissau e Cabo Verde, era superar a máxima de Nkrumah: "procurai primeiramente o reino político e todo o restante vos será dado em suplemento" (Mazrui 20I0, I25). Era necessária uma reforma total do Estado, da economia e das relações Estado-sociedade em busca de autonomia e desenvolvimento. A alternativa vista como mais adequada por movimentos como MPLA e Frente de Libertação de Moçambique (FRELIMO) era a adoção do socialismo científico e uma estruturação do Estado baseada, pelo menos projetada, no marxismo-leninismo. No Primeiro Congresso do Partido em I977, o MPLA adotou o marxismo-leninismo e declarou-se partido de vanguarda. Todavia, o processo foi constrangido pela reduzidas capacidades do Estado e da sociedade e por diferentes pressões internas e externas. Finalmente, em meados da década de i980 o ideal do marxismo-leninismo teve de ser crescentemente abandonado em prol da sobrevivência.

6 Ao contrário da UNITA e FNLA, o MPLA procurava articular um projeto nacional. O programa do MPLA aprovado em I974, na Conferência Inter-regional de Militantes, guiava esse processo pautando-se na educação da população em áreas libertas, incluindo a alfabetização e o ensino da história angolana (Wolfers and Bergerol ı983, เo9).

7 O FNLA permaneceu vinculado à identidade kongo, ao anticomunismo de Holden Roberto, e ao liberalismo de camponeses negros ligados à produção de café em Cazengo - o que lhe garantiu apoio do Zaire e dos EUA. A China procurava, igualmente, fazer frente ao movimento apoiado pela URSS e acabou apoiando o grupo. A UNITA manteve sua base de arregimentação nos ovimbundu (força política nos planaltos, em Huambo e na cidade portuária de Lobito) e contou com a liderança carismática e ideologicamente indefinida de Jonas Savimbi. Sua postura conservadora (por consequência, anti-MPLA) foi definidora do suporte de África do Sul, EUA e, minoritariamente, China (Birmingham r992, 47-50). 


\section{Capacidade Estatal: coerção, capital e legitimidade}

Os principais desafios da construção do Estado angolano estavam vinculados às capacidades reduzidas herdadas do Estado colonial português (inclusive a destruição causada pela guerra de libertação) e aos desafios imputados pela guerra interna, apoiada por forças externas. No novo projeto de Estado, as prioridades eram estabelecer a ordem interna e fomentar a capacidade econômica, por meio de uma sociedade politicamente educada e mobilizada. Nas tarefas de reconstrução, Cuba foi fundamental para reduzir o vácuo de poder no serviço público militar, administrativo, médico, de educação e segurança (Birmingham I992, 52).

Os desafios da capacidade coercitiva eram significativos, em virtude da necessidade de se construir um exército nacional a partir das forças de libertação, que fosse capaz de fazer frente a forças armadas rivais de capacidade semelhante. Dois movimentos foram adotados para essa tarefa: (i) a construção de um exército robusto baseado na identidade do movimento do MPLA (FAPLA - Forças Armadas de Libertação de Angola) e (ii) o amparo direto de forças de segurança voltadas à defesa externa nas tarefas de combate interno, logrando experiência de combate diferenciada. A aliança com Cuba foi central para a finalidade de organizar forças de defesa que protegessem os 2 mil quilômetros de fronteira com o Zaire e a mesma distância com a Namíbia. ${ }^{8}$ A tentativa de incremento da capacidade coercitiva era complementada com a participação de milícias populares (originadas na guerra de libertação) na defesa urbana e rural contra campanhas de terror da Frente Nacional de Libertação de Angola (FNLA) e da União Nacional para a Independência Total de Angola (UNITA). Não obstante, permanecia a dificuldade de penetrar o território do sul, que tornou-se controlado por UNITA e África do Sul, e de manter o controle de Cabinda, um enclave no litoral ao norte do Congo-Kinshasa, com grandes riquezas petrolíferas (metade do petróleo nacional) e atuação de grupos separatistas (Frente para a Libertação do Enclave de Cabinda - FLEC) apoiados pelo serviço de inteligência francês.

No que tange à esfera do capital, importa que desde I9I5 (contexto da Primeira Guerra Mundial), Portugal incrementara a exploração econômica da colônia, aumentando investimentos em infraestrutura para acesso e escoamento de produtos como café, diamantes e petróleo. ${ }^{9}$ Com a independência

\footnotetext{
8 Em agosto de 1976 , um acordo entre Angola e Cuba garantiu a continuidade do treinamento das FAPLA. O maior desafio era construir forças "strong enough on the ground to withstand the $S A D F$ - Africa's best NATO equipped army" (Wolfers and Bergerol 1983, 130).

9 Portugal construiu a ferrovia Benguela (iniciada em I9II e concluída em I92I), para oferecer a logística de transportes da região de Katanga no Congo até o porto de Lobito. Iniciou a
} 
e a adoção do marxismo-leninismo houve a nacionalização das fazendas e dos negócios abandonados pelos portugueses durante a guerra de libertação (a maioria deles rumou à Portugal, Brasil e África do Sul). O governo procurou estabelecer uma economia planificada centralmente que buscava a reconstrução do Estado e a sustentação dos esforços de guerra. Nacionalizou o banco central, renomeado de Banco Popular de Angola, e adotou políticas de incentivo à industrialização, como instrumento para a construção do socialismo. O projeto previa a articulação de mão de obra, que viria da população local, inclusive dos antigos grupos rivais e de angolanos exilados (Wolfers and Bergerol I983, IIO-II). Entretanto, houve dificuldades para avançar "[....] devido à falta de capital (desviado para a defesa), à escassez de mão de obra qualificada, à falta de peças de reposição e insumos e aos efeitos desestabilizadores provocados pela sabotagem da África do Sul e da Unita, além da própria incapacidade gerencial" (Visentini 20I2, 7I). Assim, em razão do estado precário da economia (após a guerra de libertação e com a guerra civil), da falta de capacidade burocrática e do reduzido apoio econômico do bloco comunista, o modelo foi sendo gradualmente abandonado. Em meados da década de i980, houve uma inclinação às forças do mercado: a crescente influência da economia Ocidental era vista em firmas de petróleo, bancos, processamento de comida e de transporte.

A legitimidade do Estado, por sua vez, era fundamentada na autoridade e identidade do regime do MPLA e em políticas distributivas. A tentativa principal era construir uma sociedade politicamente educada e que repreendia a atitude fragmentadora de grupos insurgentes como UNITA e FLEC. O MPLA procurou instigar a ideia de nação, centrando o civismo no partido e no elemento revolucionário como base para a cultura nacional. $\mathrm{O}$ africanismo era tolerado e incentivado para o resgate histórico (reviver as principais línguas tradicionais angolanas), embora as religiões fossem hostilizadas (Marcum I987, 75). Todavia, havia pouca integração e a identidade nacional era ainda insuficiente. $\mathrm{O}$ incremento da capacidade distributiva do Estado foi direcionado aos direitos sociais. A saúde e educação foram priorizadas. Já em I975 a Constituição garantia o direito a assistência médica para todos; instituiu-se o Serviço Nacional de Saúde e em dois anos os serviços de saúde tornaram-se totalmente públicos. ${ }^{\text {IO }} \mathrm{Na}$ área de educação, houve em 1975 um projeto de

extração de diamantes com criação da Companhia de Diamantes de Angola, em I9I7, e incrementou a produção de café e outros produtos (pesca e manufatura) e cultivos forçados (além do café havia milho, feijão e trigo). A produção petrolífera foi incrementada a partir da década de I950 e nos anos i960 companhias estrangeiras passaram a investir no setor, principalmente norte-americanas.

Io O foco na medicina preventiva e na educação da população, com amparo cubano, possibilitou a integração da medicina tradicional à medicina científica. Hospitais provinciais foram 
reestruturação educacional que remontava à luta de libertação, quando cerca de $90 \%$ da população era analfabeta em português. O Congresso do MPLA em 1977 iniciou o processo de reconstrução do sistema educacional angolano e criou um modelo que integrava estudantes regulares e trabalhadores e incentivava a educação universitária para servir quadros ao partido e oficiais às FAPLA. Não obstante, populações do sul e leste reclamavam de marginalização por parte do governo central e acabavam servindo com base de arregimentação para a UNITA, gerando desafios à legitimidade do MPLA e do Estado.

\section{As Relações Estado-Sociedade}

A política de Angola foi dominada desde 1975 pelo partido MPLA. Seguindo princípios marxista-leninistas o partido penetrava em todas as esferas do Estado e da vida pública. O governo era formado pela liderança do partido, comandada principalmente por grupos urbanos educados, geralmente elites mbundu e mulattos, ainda que incentivasse o erguimento dos interesses nacionais acima das lealdades étnicas e tribais (Wolfers and Bergerol I983, I23-4; Malaquias 2000, I09). Recusava assim a aceitar o uso de ações afirmativas para garantir a participação política de outros grupos étnicos no governo (Marcum I987, 75). O projeto político do MPLA objetivava estabelecer uma sociedade igualitária, uma economia planificada e industrializada, e a autonomia e o desenvolvimento nacionais. Mais do que um simples alinhamento ideológico o modelo marxista-leninista era atrativo como "[...] promise of governmental efficiency, authority, and social discipline in the Soviet model" (Keller I987, II). ${ }^{\text {II }}$ Suas prioridades principais eram educação política e reconstrução econômica. Contudo, sua capacidade para tanto era reduzida e as metas traçadas pelo Estado tiveram de ser gradualmente flexibilizadas e a autonomia vislumbrada acabou sendo secundarizada frente à necessidade de sobrevivência e integridade do Estado (ante à fragmentação interna) e do regime (diante de movimentos/partidos alternativos). ${ }^{.2}$

reformados e amparados por centros de saúde em cidade menores. Em termos de recursos humanos, havia grande desafio, visto que $90 \%$ dos expatriados abandonaram seus empregos em serviços essenciais do Estado. Cuba provinha médicos e técnicos enquanto angolanos eram treinados. Alemanha Oriental, URSS, Iugoslávia, Bulgária e Holanda também enviaram voluntários. Campanhas massivas de vacinação executadas por voluntários foram realizadas (uma de I977 foi inclusive premiada pela Organização Mundial da Saúde (OMS)).

II Em fevereiro de 1977 o MPLA inaugurou a Escola Nacional do Partido e declarou aderência ao socialismo científico. No Primeiro Congresso do MPLA, em dezembro de 1977, instaurou o MPLA-PT (Partido do Trabalho). Este adotou uma forma de organização piramidal e assumiu liderança política, econômica e social sobre o Estado (Marcum I987, 72-3).

I2 A dependência do amparo coercitivo cubano e soviético e dos capitais ocidentais resultou,

146 Austral: Revista Brasileira de Estratégia e Relações Internacionais v.4, n.7, Jan./Jun. 2015 
O MPLA articulava alianças em uma estratégia de poder e participação popular que buscava aproximar a sociedade por meio de comitês populares e organizações de massa. Todavia, devido à base de formação do MPLA, predominantemente urbana, grupos de regiões distantes da capital acabavam sendo preteridos na estrutura política do partido e se tornavam fontes de oposição (Marcum I987, 74). ${ }^{13}$ A dificuldade do diálogo com regiões rurais mais distantes de Luanda, a reduzida participação dos camponeses no processo político e tensões com trabalhadores contribuíam para o fortalecimento de grupos opositores mais ameaçadores. Depois da estabilização do MPLA no poder o seu maior desafio interno tornou-se a UNITA ${ }^{14}$ (e, em menor medida a FLEC), posto que com a guerra constante (exceto talvez pelo período de I976-1978) a elite governante nunca dispôs de tempo hábil para consolidar o poder do Estado ao longo do território (Malaquias I999, 24). Mesmo com as dificuldades na construção das capacidades estatais, as ameaças internas e externas puderam ser enfrentadas graças ao amparo externo, inclusive na extração de seus recursos naturais abundantes (petróleo), que afiançou uma política regional revolucionária.

\section{Elites e Política Externa Regional em Angola (1975-1988)}

A política externa regional de Angola derivava desse processo amplo de construção do Estado e da centralidade das elites do MPLA. A figura do presidente era relevante para a formulação das diretrizes centrais de política externa. Entretanto, o partido e seus órgãos internos estabeleciam os objetivos políticos e linhas de ação fundamentais. Três eram as principais esferas decisórias do MPLA: (i) o Congresso do Partido, que reunia uma assembleia

concomitantemente, na perda de autonomia do Estado frente a pressões externas e na flexibilização do seu projeto político revolucionário interno (marxismo-leninismo) e externo (ordem regional desenvolvimentista).

I3 Por exemplo, tensões surgiram no relacionamento com os trabalhadores articulados na União Nacional dos Trabalhadores Angolanos (UNTA), à medida que o MPLA apoiava a centralização sindical e as organizações verticais para incluir todos os trabalhadores em ramos de atividades. A UNTA criticava a gestão do governo por não implementar uma participação democrática dos trabalhadores no monitoramento da produção (Wolfers and Bergerol I983, II8-I2I).

I4 A UNITA não possuía uma plataforma política clara tampouco uma posição ideológica. Mantinha um discurso etnitizado de alinhamento aos ovimbundu e outros grupos do oeste e sul de Angola (Tvedten I997, 30-I). Populações dessas regiões ressentiam-se da marginalização nas políticas do governo central desde o período colonial. Todavia, o grupo detinha uma importante liderança carismática, Jonas Savimbi, e suporte externo significativos, o que lhe possibilitou uma efetiva reorganização após a derrota de I975. 
de delegados e estabelecia os direcionamentos políticos gerais; (ii) o Comitê Central, que formulava as políticas específicas em áreas de responsabilidade do seu secretariado, incluindo os departamentos de Política Externa e Defesa e Segurança; e (iii) o Bureau Político, órgão eleito do Comitê Central e mais influente do partido, mantinha o poder de fiscalização da implementação da política partidária (ou seja, possuía grande interferência na agenda). As relações entre partido e Executivo dominavam o processo decisório em política externa. Se o presidente, na figura de presidente do partido e chefe do governo, era constrangido pelas linhas de ação político-ideológicas do MPLA, ele também possuía a capacidade de afetar a política externa pelas suas particularidades no estilo de implementação e mediante eventuais espaços de agência. Além do presidente e do partido, os militares acabaram tornando-se gradualmente uma fonte vital de input nas políticas doméstica e externa, devido aos desafios securitários domésticos e externos (Malaquias 2002, I5, I9).

Além disso, contribuíam para a conformação da política regional as pressões existentes à EDPE. As principais em todo o período eram originárias da relação entre grupos internos (UNITA, FLEC) e seus aliados externos (África do Sul, Zaire, EUA). Destacava-se aqui a África do Sul, o principal garantidor da ordem regional de perfil conservador, que percebia em Angola grandes ameaças para a manutenção desta. O Zaire, país com ação secundária na região, também percebia em Angola desafios à estabilidade de uma ordem conservadora, de perfil neocolonial. Os EUA, embora grandes defensores da ordem liberal internacional, priorizavam a estabilidade regional e a sua transição gradual e segura para uma ordem liberal, afastando a possibilidade de radicalismos. A ação de todos, contudo, só tendia a aumentar as tensões regionais, uma vez que se valiam do uso da força e que encontravam em Angola um Estado e regime determinados a garantir sua autonomia.

Como consequência, entre I975 e I988 a política externa regional angolana foi fundamentada na tentativa de transformação da ordem regional como forma de aumentar as chances de sobrevivência do Estado e do regime. No longo prazo, tal estratégia possibilitou a construção de um ambiente regional gradualmente favorável à unidade estatal e integridade territorial angolana. A realização dessa estratégia seguia diversas frentes. Instrumentos de barganha, como o amparo à South West Africa People's Organization (SWAPO) e ao African National Congress (ANC) eram vistos de forma dupla. Primeiramente, eram ideologicamente relevantes, na forma de solidariedade pan-africana e revolucionária (Marcum I987, 79). Em segundo lugar, e mais importante, ambos os movimentos eram tomados como instrumento de barganha frente aos principais apoiadores da UNITA. A solidariedade revolucionária era, contudo, apenas um de três instrumentos adotados na grande estratégia 
regional. O segundo deles era a configuração de alianças regionais, o que redundou no seu ingresso aos Países de Linha de Frente (PLF) e a articulação da Southern African Development Coordination Conference (SADCC). Por fim, havia o suporte básico de todas essas frentes de ação: as políticas de fortalecimento da capacidade do Estado (sobretudo militar) e a garantia de amparo constante em forças, assessores e equipamentos de aliados extrarregionais. Esse instrumento capacitava a ação de Angola em todos os cenários, inclusive caso os dois anteriores falhassem. Servia como forma de assegurar a sua sobrevivência frente a forças internas em Cabinda e no sul e a rivais regionais agressivos (África do Sul e Zaire). Todavia, o projeto regional revolucionário perdeu gradualmente o seu ímpeto, dada a inflexão sul-africana e a reduzida capacidade do Estado (somada às expectativas de redução do suporte externo) de arcar com custos internos e externos da mudança.

\section{Elites e Política Externa Regional em Neto (1975-1979)}

Durante o breve governo de Agostinho Neto, a EDPE foi gradualmente estruturada nas principais lideranças do partido, como visto anteriormente. A retórica de não alinhamento e independência do presidente deu o tom inicial da ação externa. A ação de Neto era vista na política autonomista frente a URSS, já que este país havia relutado em oferecer amparo ao partido no limiar da independência. O vice de Neto e ideólogo político do MPLA, Lúcio Lara, lembra que somente após o MPLA ter obtido apoio da Iugoslávia (armamentos) e maior amparo de Cuba é que as relações com a URSS melhoraram (Brittain I996, I). Neto procurava desvincular Angola da disputa leste-oeste e a sua cooperação com Cuba era privilegiada, já que envolta do ideal terceiro-mundista (Neto visitou Cuba em I976 e i977, e Fidel e Raul Castro visitaram Angola em I977). A postura política de Neto procurava, prioritariamente, garantir a estabilidade de seu domínio interno e encontrar recursos para isso. ${ }^{15}$ Todavia, com a atuação de forças externas, ficava cada vez mais clara a dificuldade em alcançar estabilidade sem uma política externa claramente revolucionária e ativa. ${ }^{16}$

As pressões internas e externas ao regime do MPLA foram significati-

I5 Por exemplo, com as dificuldades econômicas internas, Neto permitiu a continuidade de operações de companhias ocidentais em Angola e buscou abrir canais diplomáticos com os EUA.

I6 O posicionamento mais revolucionário de líderes influentes do partido, como Lúcio Lara, Iko Carreira e Paulo Jorge, foi se fortalecendo. Essas lideranças percebiam as ações de Zaire e África do Sul como parte do confronto da Guerra Fria e no contexto de uma dominação neocolonial na África. A alternativa mais natural seria o incremento da aliança com URSS e Cuba (Malaquias I999, 25). 
vas nesse período inicial e colaboraram fortemente para a conformação de sua política regional. Contribuía a experiência conflitiva do processo de independência ${ }^{17}$ - que transcorreu com grande ingerência externa de rivais regionais (Zaire e África do Sul) e de potências extrarregionais (EUA, URSS e Cuba ${ }^{18}$ ) - e resultou na vitória ainda instável do MPLA. Após a independência, as pressões mais significativas à segurança das EDPE vinculavam-se, portanto, à consolidação do Estado e do regime. Internamente, ameaças à liderança de Neto surgiram dentro do MPLA com o movimento radical de Nito Alves que procurou remover o grupo de Luanda (mais moderado e, relativamente, intransigente) do poder, imputando um golpe em 27 de maio de $1977 .{ }^{19}$ Mais do que a competição entre elites, as pressões sociais de grupos rivais tornaram-se constantes, vindas de FNLA, FLEC e, principalmente, UNITA. Externamente, havia ataques diretos da África do Sul, que tinham como pretexto a desmobilização da SWAPO, e a continuidade do suporte à reorganização da UNITA20. No norte, o Zaire recuava após a derrota do FNLA, mas mantinha-se nocivo à liderança de Neto.

Como consequência, Neto e a cúpula do MPLA implantaram uma política externa regional reivindicatória e pró-ativa para assegurar a existência do Estado e o reconhecimento do MPLA. Para isso, a política externa deveria servir de instrumento para a vitória na guerra civil, o que, por sua vez implicava na transformação da ordem regional. Buscava-se concomitantemente (i) a defesa da soberania dos Estados recém-independentes, (ii) a construção de

I7 Após a saída dos portugueses no início de I975, o MPLA visou garantir o controle da capital Luanda como forma de assegurar a autoridade do Estado (Birmingham I992, 49). Os demais grupos igualmente perceberam a relevância dessa estratégia e rumaram à capital. O FNLA seguiu pelo norte apoiado por I.200 homens do Zaire, enquanto a UNITA tomava o sul do país com suporte sul-africano.

I8 Os EUA desrespeitaram o Acordo de Alvor e enviaram já em janeiro de I975, US\$300 mil em ajuda ao FNLA, mediado pela estação da CIA no Zaire. Como resposta, países do leste europeu enviaram armas e equipamentos para o MPLA, o que foi reforçado pelo apoio soviético, mais próximo à independência. Assessores militares externos, sobretudo cubanos, também serviram de amparo ao movimento. A UNITA recebeu na mesma época em torno de US\$ 32 milhões em ajuda secreta dos EUA para evitar o controle de Luanda pelo MPLA (Bauer and Taylor 2005, I48-9). O suporte foi, contudo, insuficiente para tomar a capital do MPLA, que contava com o incremento da participação de forças cubanas (2.000 tropas), que auxiliariam no bloqueio da ofensiva no sul e a expulsão do FNLA que já penetrava a capital.

I9 A tentativa logo fracassou devido ao mau planejamento, ao suporte insuficiente da população e militares e à oposição das forças cubanas (Birmingham I992, 73-76). O movimento serviu para acelerar as políticas de reforma do Estado concretizadas na adoção do marxismo-leninismo em i977.

20 A África do Sul apoiou o ressurgimento da UNITA e a sua expansão de bases em Cuando-Cubango (sudeste) para os planaltos centrais, onde se situavam eixos infraestruturais (ferrovia de Benguela). 
mecanismos regionais de distribuição de desenvolvimento (SADCC) pautados no imperativo dos direitos sociais das populações da região e (iii) a construção solidária da segurança regional, sob a compreensão de que a sua própria segurança estava imbricada à de grupos e Estados vizinhos aliados.

A ação menos custosa sustentava-se no estabelecimento de alianças regionais com os PLF, complementada por uma tentativa de mediação e diálogo regional com África do Sul e Zaire. Pessoalmente, Neto acreditava haver espaço para a mediação. Interpretava inicialmente que “[...] state's territorial integrity ultimately depended on its ability to establish good relations with neighboring states" (Malaquias I999, 25). ${ }^{2 \mathrm{I}}$ Essa posição foi sendo cada vez menos viável na medida em que as respostas dos vizinhos não se alinhavam às expectativas de cooperação (Total Strategy da África do Sul) e que a linha dura do partido assumia maior protagonismo. O resultado foi o gradual aumento de operações militares nos fronts norte e sul como complemento e alternativa à iniciativa diplomática. No front norte, as guerras de Shaba I e Shaba II foram indicativos desta postura impetuosa de oposição e reação às forças conservadoras regionais. Tratou-se de dois conflitos armados ocorridos em I977 e 78 , respectivamente, que representaram a resposta do MPLA à invasão de tropas do Zaire. ${ }^{22}$ No front sul, a política de defesa e oposição à ordem sul-africana baseava-se no crescente apoio a movimentos de libertação nacional opostos ao regime do apartheid, o qual identificava no MPLA o principal inimigo de sua ordem regional.

\section{Elites e Política Externa Regional em Dos Santos (1979-1988)}

Com a morte de Agostinho Neto em io de setembro de I979, a ascensão de José Eduardo dos Santos representou o esgotamento da opção negociada e o avanço da política regional defensiva e combativa sugerida pela linha dura do partido. Dos Santos carregava maiores vínculos pessoais com o bloco comunista. Era um engenheiro de petróleo formado na URSS, o que aumentou a sua proximidade com este país e Cuba, facilitando o incremento

2I Além disso, em 2i de julho de I978, Neto afirmou que não tinha reservas em estabelecer relações diplomáticas com os EUA. Washington mantinha, contudo, a precondição da saída dos cubanos e a reconciliação interna com o seu proxy UNITA.

22 Em março de 1977, Neto deu apoio tácito de Angola à invasão do Zaire por milhares de katangueses à província de Katanga (agora Shaba). Os chamados Tigres do Frente Nacional de Libertação do Congo (FNLC) pegaram Mobutu desprevenido e despreparado. Entretanto, devido à grande importância de Shaba para a economia do Zaire e aos investimentos mundiais no país (o foco dos ataques, Kolwezi, era uma das cidades com maiores reservas de cobre do Zaire), uma intervenção coordenada pelo ocidente foi lançada e garantiu a proteção de Mobutu nas duas ocasiões (Leogrande i980, 24-27). 
de cooperação para enfrentar os desafios internos. Dos Santos procurou centralizar o processo decisório de política externa ao estabelecer em I984 um Conselho de Defesa e Segurança (presidido pelo próprio presidente), que se tornou o órgão mais alto de tomada de decisão do país (Hodges 2004, 53). A instituição demonstra o incremento da centralidade de um grupo fechado e próximo ao presidente no processo de definição da política externa.

Além disso, a insegurança de Dos Santos frente a elites internas contribuiu para o seu maior alinhamento à URSS e Cuba. Dos Santos preocupava-se com a deterioração da situação interna e estava em uma posição mais fragilizada por ser jovem (37 anos) e não ter tido participação significativa na luta de independência. Havia a necessidade de criar uma base política mais sólida e estabelecer comando e liderança sobre os militares. URSS e Cuba, por seu turno, tinham agora maiores interesses em atuar no conflito angolano. ${ }^{23}$ No que se refere aos conflitos armados, as pressões no norte acabaram cedendo lugar para as conflagrações no sul. O front norte se acomodava devido aos resultados das Guerras de Shaba ${ }^{24}$ e o front sul se tornava definitivamente palco principal da guerra. Foi nesta época que a África do Sul expandiu o seu envolvimento no conflito angolano. Forças sul-africanas ocupavam o sul do país e declaravam apoio público à UNITA e garantiam um escudo protetor para as operações do grupo, agora ainda mais impactantes. ${ }^{25}$ Pressões extrarregionais

23 A primeira, para fazer frente ao crescente conservadorismo da política externa norte-americana. A segunda, para fortalecer a sua posição de liderança no Movimento dos Não-Alinhados (MNA), em um momento de crise econômica internacional. A renovada aliança com URSS e Cuba provou-se fundamental para enfrentar novos desafios à estabilidade do Estado, sobretudo no sul do território.

24 Apesar de demonstrar o grau de tensão que viviam Angola e Zaire naquela época, as guerras de Shaba possibilitaram um acordo entre os dois países em meados de i978. Zaire se comprometeu a não fornecer ajuda para UNITA, FLEC e FNLA - enquanto Angola prometia desarmar os Tigres e acentuar esforços para reabrir a ferrovia de Benguela (Leogrande i980, 27). A promessa de Mobutu foi cumprida apenas parcialmente (mantinha-se como eixo logístico de auxílio à UNITA e apoiava grupos desestabilizadores minoritários, como o Comitê Militar de Resistência de Angola), mas o Zaire se afastava da região da África Austral, mantendo participação indireta para somente na década de I990 retornar a participar ativamente das dinâmicas regionais.

25 Em I979 a UNITA já estava reestruturada pela South African Defence Force (SADF) e buscava operar no centro-sul do país, com o objetivo de empreender grande devastação às atividades econômicas, bloqueando a ferrovia Benguela, atacando produções agrícolas e aldeias na região produtiva do planalto central, e programando operações ao norte para romper com acesso do governo à exploração de petróleo e diamantes (Malaquias I999, 28). Suas táticas de terra arrasada, roubo, pilhagem e sabotagem de comboios médicos levaram milhões à morte e à fome. Como resposta, o MPLA tratava populações arregimentadas pela UNITA com igual crueldade, relembrando o perfil da guerra de libertação. Entre I982-83 houve a intensificação dos ataques de UNITA e África do Sul e grande parte da província de Cunene foi tomada. Em I983, a UNITA atacou Cangamba, na província de Moxico, com suporte aéreo sul-africano (que testava 
vinham da política norte-americana do linkage, a qual envolveu Angola diretamente na barganha para a independência da Namíbia, colocando a presença cubana como moeda de troca para a retirada da África do Sul dos territórios meridionais. Este constructive engagement diplomático, que retoricamente procurava instaurar um clima de confiança e desengajamento do apartheid, foi complementado com o engajamento estratégico da Doutrina Reagan.

O incremento das ameaças internas e externas levaram José Eduardo dos Santos, em momento inicial, a aprofundar a aliança com a URSS. Três meses após assumir a presidência, viajou ao país com o intuito de garantir a continuidade da ajuda soviética. ${ }^{26} \mathrm{O}$ amparo militar garantiu a sustentabilidade das políticas doméstica e regional do MPLA (Brittain I986). ${ }^{27}$ Esta última mantinha a posição de transformação significativa da ordem para princípios mais distributivos. É certo que devido às dificuldades de se manter o programa de fortalecimento das capacidades estatais, Dos Santos tentou avaliar a capacidade de diálogo de P.W. Botha nas negociações que levaram ao Acordo de Lusaka de $1984 .{ }^{28}$ Todavia, devido à dificuldade de concretização de uma saída regional dialogada, Angola, como resposta, procurou retomar uma luta de sobrevivência com amparo soviético e cubano. A intensidade dos conflitos armados escalou a partir de 1985 , com maior envolvimento sul-africano ${ }^{29}$ e do suporte norte-americano ${ }^{3 \circ}$ à UNITA. Somente quando tropas angolanas im-

novos equipamentos). O ano terminava com as unidades sul-africanas $300 \mathrm{~km}$ dentro do país (Chan i990, 57-9).

26 As viagens foram repetidas na medida em que as ameaças da UNITA cresciam (1983, I986 e I988). Em I986, Dos Santos assinou tratado de amizade e cooperação com a União Soviética.

27 Entretanto, pouco apoio econômico comunista existia, uma vez que Angola, assim como Moçambique, não fazia parte do COMECON (Conselho para Assistência Econômica Mútua). Havia, consequentemente, necessidade de amparo de capitais ocidentais, o que aumentava a vulnerabilidade do Estado.

$28 \mathrm{O}$ acordo previa a retirada das forças sul-africanas de Angola, que manteria sob controle as atividades da SWAPO. A África do Sul também deveria adotar a resolução 435 do Conselho de Segurança das Nações Unidas (CSNU) sobre a independência da Namíbia. Entretanto, assim como em Nkomati, a África do Sul não honrou seus compromissos; levou mais de um ano para retirar suas tropas e nunca cessou o amparo à UNITA.

29 Em I985, na Batalha de Mavinga, o MPLA empreendeu operação militar de larga escala complementada com estratégias diplomáticas prévias de aproximação com países apoiadores da UNITA, como Marrocos, Zaire e Costa do Marfim. A África do Sul abandonou de vez a solução negociada e mobilizou suporte militar (aéreo, inclusive) às forças da UNITA, salvando o grupo do avanço das FAPLA e marcando o recomeço das intervenções militares diretas da África do Sul (Chan I990, 57-9).

30 Em i986, os EUA provinham abertamente US\$25 milhões para Savimbi (Bauer and Taylor 2005, I49). Reagan proveio armas sofisticadas às forças da UNITA, como mísseis antiaéreos Stinger (um dos maiores desejos de Savimbi manifestado em viagem à Washington realizada em janeiro de I986). Os custos das guerras de baixa intensidade eram reduzidos apenas para o 
putaram grande derrota às forças sul-africanas no sul de Angola é que houve maiores condições para a solução negociada. Isso ocorreria nas batalhas de I987/I988, sobretudo em Cuito Cuanavale. Negociações mais contundentes começaram em maio de I988, quando EUA e URSS "were increasignly in accord on the need for settlements of 'regional conflicts" (Minter I994, 49).

O acordo tripartite era visto por Angola e África do Sul como benéfico. A África do Sul pôde ver a saída dos 50 mil cubanos e cedeu à inevitável independência da Namíbia. Angola conseguiu se ver livre da ameaça sul-africana na fronteira sul e não precisou se comprometer naquele momento com um acordo envolvendo a UNITA, agora fragilizada com a retirada do seu principal apoiador. Os EUA, por outro lado, viam como vitoriosa a diplomacia do constructive engagement, a despeito da destruição que ela e sua contraparte (Doutrina Reagan) trouxeram para a região. Com a perspectiva do retrocesso sul-africano e da transformação da ordem regional, a política regional angolana reduziu-se temporariamente em ambições de mudança e ímpeto de ação.

Em suma, e no período de Neto (I975-79), a instável liderança política do MPLA buscava ser compensada com uma política de fortalecimento de capacidades estatais e políticas distributivas que se reproduziam em um projeto regional desenvolvimentista. As crescentes pressões internas e externas eram respondidas com alto ímpeto de ação regional para a mudança. Com a ascensão de Dos Santos (I979-88), o incremento relativo das capacidades coercitivas e o maior apoio externo garantiu a capacidade de reação às grandes pressões externas mediante uma política ainda mais impetuosa de apoio à SWAPO e ANC e reação militar contra a invasão sul-africana. Já, no momento de transição em I988, a diminuição das pressões externas com a retração da África do Sul permitiu a redução do ímpeto de ação e a flexibilização do projeto regional (aceitação do linkage e maior diálogo com ocidente).

\section{ESTADO, ELITES E POLIITICA EXTERNA EM ANGOLA (1989-2010)}

Na África Austral, a transição da ordem global no pós-Guerra Fria e do regime do apartheid na África do Sul contribuíram para a emergência de uma ordem regional de cunho prioritariamente liberal, que serviu para a continuidade da centralidade sul-africana. A defesa dos direitos humanos e a aceitação da ingerência externa passaram a coexistir de forma instável com o princípio do respeito à soberania negativa (jurídica) dos Estados. A liberalização eco-

Pentágono, pois deixaram para os países do terceiro mundo uma marca devastadora em vidas humanas e impactos negativos no desenvolvimento, dada sua estratégia contrarrevolucionária (Birmingham I992, 84; Klare I985 on-line).

154 Austral: Revista Brasileira de Estratégia e Relações Internacionais v.4, n.7, Jan./Jun. 2015 
nômica representada pela implantação de programas de ajuste estrutural foi adotada, mesmo nos antigos regimes socialistas ou marxista-leninistas, e as instituições de integração regional abraçaram os seus fundamentos. O princípio da "boa" governança e programas de desenvolvimento de cunho assistencialista, e muitas vezes descolados de alternativas de emprego e renda para a população, foram adquirindo prioridade. A segurança humana passou de uma discussão retórica para a justificativa de reforma de forças de segurança nacionais e como alicerce para a gestão da segurança regional. Com ímpeto variado, Angola manteve-se ainda posicionada pela mudança dos fundamentos do status quo, procurando a construção de uma ordem de defesa da soberania dos mais fracos (jurídica e empírica), que priorizasse a garantia de direitos sociais e que sustentasse uma perspectiva coletiva de segurança (regional ou nacional). Sua postura frente à ordem regional pode ser compreendida pelo estudo do processo de construção do Estado e dos interesses e segurança das EDPEs.

\section{Construção do Estado em Angola (1989-2010)}

O final da Guerra Fria trazia consigo grandes desafios para Angola. Assim como a África do Sul, o país perderia gradualmente a sua relevância estratégica na competição sistêmica global. Seus principais aliados experimentavam fragmentação estatal (URSS e países do leste europeu) ou isolamento (Cuba). Por outro lado, o desafio foi acompanhado com a distensão da ordem regional e a abertura de espaços de ação para o país. Com a transição na África do Sul e a garantia de uma ordem regional menos ofensiva aos interesses do MPLA, o governo poderia focar suas energias na solução do conflito interno. Além disso, a defesa mais ativa de uma ordem liberal global pela única superpotência restante (EUA) reduziria os ganhos em arcar com os custos econômicos e políticos da empreitada violenta de Jonas Savimbi. Posteriormente, a abundância de recursos naturais estratégicos e a relevância de sua posição no Atlântico Sul, faria com que Angola viesse a recuperar seu papel estratégico global para potências tradicionais (EUA) e emergentes (China, Brasil e Rússia).

Internamente, os desafios eram mais relevantes dada a destruição econômica, social e humana gerada por décadas de guerra e a continuidade de conflagrações em diferentes frentes. A escala do problema continuava a drenar recursos que poderiam ser destinados a políticas de desenvolvimento. Desde o início da década de I990, Angola estabeleceu quatro grandes transições, "from war to peace and reconciliation; from humanitarian emergency to rehabilitation, recovery and development; from an authoritarian, one-party system 
of governance to pluralist democracy; and from a command economy to one based on the laws of the market" (Hodges 2004, I99). Desafio ainda maior era enfrentar essas transições de maneira simultânea (Bauer and Taylor 2005, I4I). O primeiro movimento foi iniciado em dezembro de I990, quando o Congresso do partido renunciou formalmente ao marxismo-leninismo e consolidou, em maio de I991, uma reforma constitucional que promulgou um Estado democrático e multipartidário. A reforma abriu caminho para uma legislação eleitoral que amparou as eleições de setembro de i992. No mesmo mês, uma nova revisão constitucional foi aprovada, estabelecendo mecanismos de descentralização governamental. Concomitantemente, o nome do país foi alterado para República de Angola. Além disso, os desafios redundaram em crescentes esforços de fortalecimento da capacidade estatal, o que habilitou o país para estabilizar-se internamente e possibilitou políticas mais ousadas em nível regional e continental.

\section{Capacidade Estatal: coerção, capital e legitimidade}

Angola foi o último Estado do núcleo de interações da África Austral a estabilizar a sua guerra civil. A extensão e profundidade de seu conflito armado lograram ao país grande diferencial em capacidades, mas também desafios consideráveis. No tocante à coerção, com o Acordo Tripartite e a consequente saída das tropas cubanas, Angola tornou-se cada vez mais solitária no combate às (agora predominantes) ameaças securitárias internas. Essa realidade foi enfrentada mediante grandes investimentos na modernização das Forças Armadas Angolanas (nome adotado após 1992). A despeito do passado de cooperação com a maioria dos países da região, ameaças dos grupos guerrilheiros internos operando em solo nacional e estrangeiro (em geral, apoiados por regimes rivais), durante todo o período, legitimaram crescentes gastos em defesa e a adoção de forças armadas robustas e de um perfil de equipamento que engloba capacidades para guerra regular. ${ }^{3 \mathrm{I}}$ Durante a guerra contra a UNITA, Angola desenvolveu uma das Forças Armadas mais poderosas do continente (Jane`s 2009, 5), que, até 2002, estavam estabelecidas no território de três dos seus quatro vizinhos (RDC, Congo e Namíbia), com lutas ocasionais na fronteira da Zâmbia. Após I999, o aumento dos preços do petróleo possibilitou um processo de relativa modernização das FAA, sobretudo do exército e da aeronáutica, em um período que também abarcou a fase final

\footnotetext{
3I A reforma das forças armadas e constabulares foi iniciada na década de $90 \mathrm{com}$ a primeira integração dos insurgentes da UNITA nas instituições nacionais e o posterior enxugamento das forças e redução dos gastos militares. A reforma fracassou com a retomada da luta por parte da UNITA em iو98.
} 
da luta contra a UNITA. Desde o início dos esforços de contrapor a retomada das ações da UNITA, houve a compra de novos equipamentos ${ }^{32}$ e novos programas de treinamento ${ }^{33}$ e modernização doutrinária ${ }^{34}$. Após 2002, a nova Reforma do Setor de Segurança (RSS) angolana incluiu a integração de uma pequena parte das forças rebeldes e foi realizada quase sem suporte externo ${ }^{35}$, além de basear atualmente no esforço mais concreto de estruturação de um exército nacional..$^{6}$ Como resultado parcial desse processo de fortalecimento, Angola se habilita ao posto de potência regional (Castellano da Silva 20I2).

$\mathrm{Na}$ esfera do capital, a disponibilidade de recursos naturais gerou grandes oportunidades e desafios para o fortalecimento do Estado. A disponibilidade de petróleo financiou o processo de reforma das Forças Armadas Angolanas (FAA) e possibilitou a autonomia do Estado na definição da estratégia adotada no conflito. Ademais, após 2002 a economia angolana foi diretamente favorecida pelo final da guerra civil e pelo aumento dos preços

32 Entre I998 e 2000 foram comprados dos estoques do Pacto de Varsóvia 320 MBTs (Main Battle Tanks), I6o AIFVs (Armoured Infantry Fighting Vehicles), mais de Ioo peças de artilharia, 46 multi-lançadores de foguetes, alguns aviões de ataque Sukhoi Su-22 Fitter (reforçando o estoque já existente desses aviões) e alguns helicópteros de ataque Mi-24 Hind. Avanços qualitativos também foram obtidos com a aquisição de algumas unidades de equipamentos mais modernos, como o caça Sukhoi Su-27 Flanker (Jane`s 2009).

33 Houve o treinamento das FAA por parte de Portugal na década de I990 e, principalmente, por empresas militares privadas sul-africanas e norte-americanas desde I993. Pode-se citar ainda um acordo militar de treinamento firmado em 2000 com a Rússia, englobando o apoio técnico para a operação de equipamentos recém comprados de países da ex-URSS.

34 Se até a década de 1990 a doutrina militar angolana misturava aspectos do pensamento militar português às escolas soviética, cubana e do Pacto de Varsóvia, em meados da década de I990 a retomada da guerra por parte da UNITA provocou uma sutil alteração neste perfil. A assessoria externa da Executive Outcomes possibilitou um refinamento do estilo da era soviética, mediante a criação de novos Grupos Operacionais de Manobra, de característica reduzida. Trata-se de batalhões de formação de tipo reduzido e com capacidade convencional, mas muito mais rápidos e flexíveis. Esta realidade fez com que os insurgentes fossem derrotados como uma ameaça convencional em 2000 , modificando o seu perfil de combate para a tática de guerrilha. Assim, ressalta-se que apesar de a formação ter se especializado no perfil de mobilidade, a estratégia convencional permaneceu presente nas FAA e visível no tamanho do exército e no perfil das últimas aquisições (MBTs).

$35 \mathrm{O}$ programa de desmobilização buscava reintegrar à sociedade aproximadamente 1oo mil homens da UNITA. Destes, apenas 5 mil seriam admitidos nas forças armadas e na polícia nacional. Nos maiores escalões, 30 generais da UNITA foram incorporados às FAA e três brigadeiros da UNITA foram estabelecidos na Polícia Nacional de Angola (PNA).

36 Isso, mediante as atuais prioridades de (i) aumentar o profissionalismo das forças armadas, principalmente do exército; (ii) elevar a prontidão de combate dos soldados; (iii) incrementar a organização, o controle e o registro do pessoal e dos equipamentos; (iv) aumentar a imposição de disciplina; e (iv) melhorar as condições de vida dos soldados e incrementar as taxas de alfabetismo entre os militares (Jane`s 2009, 7I). 
do petróleo com a proximidade da Guerra do Iraque. Os diamantes também trazem certo conforto para a economia angolana, principalmente após a aprovação do esquema de certificação de origem desse minério com o Processo de Kimberley de 2003 (introduzido pela resolução 55/56/2003 da AGNU). Todavia, a disponibilidade de recursos naturais gerou igualmente ao menos três grandes desafios ao fortalecimento do Estado, a saber: (i) colaborou diretamente para a continuidade quase indeterminada dos conflitos armados ${ }^{37}$; (ii) a disponibilidade de recursos "fáceis" atrasou o processo de diversificação da economia e o incremento da acumulação de capita $3^{8}$; e (iii) contribuiu, como consequência, para o distanciamento do Estado em relação à sociedade. ${ }^{39} \mathrm{~A}$ dependência econômica dos recursos naturais e a destruição de outros setores econômicos (pesca, produção de café e indústria) com a guerra denotam a demanda de desenvolvimento de outros setores da economia nacional.

$\mathrm{Na}$ esfera da legitimidade, as dificuldades derivadas da guerra civil (destruição e escoamento de recursos), aliadas à escassez de recursos humanos, levaram a grandes problemas burocráticos. Embora houvesse investimentos significativos na capacidade coercitiva e aumento no rendimento de recursos naturais, o Estado teve dificuldades em expandir a sua presença pelo território e desempenhar tarefas básicas. Na década de I990, a falta de renumeração fazia com que a burocracia operasse muitas vezes de forma voluntária ou extorquindo populações. O provimento de serviços públicos como saúde, educação, transporte e comunicação foi igualmente prejudicado com os anos de guerra e o processo de liberalização econômica. ${ }^{4}$ Por outro

$37 \mathrm{O}$ petróleo financiou a ação do governo central enquanto os diamantes (principalmente os aluviais, de acesso facilitado) deram fôlego para a continuidade das operações de Savimbi por quase três décadas, gerando entre I992 e 2000 cerca de US\$4 bilhões em receitas (Billon 2001, 69).

38 A vitória na guerra não implicou o estabelecimento de diversificação econômica e o desenvolvimento interno, mas garantiu a continuidade de uma economia de enclave baseada em recursos naturais em que o setor do petróleo corresponde a quase 60\% do PIB.

39 Os recursos naturais angariaram ao Estado capacidade de ação sem prestação de contas à sociedade, na medida em que possuía capacidade "autônoma" e indeterminada de financiamento. Há inclusive poucos limites para a corrupção, haja vista que se estima que bilhões de dólares anuais derivados da economia do petróleo não sejam contabilizados (GlobalWitness 2002).

40 O fim do conflito armado não elidiu as dificuldades de habitação de regiões anteriormente conflagradas, já que quase quatro milhões de angolanos foram deslocados internamente $(2,6$ milhões somente após I998). A proliferação de minas terrestres afeta a vida de milhões de indivíduos e prejudica o cultivo de terras. Alguns estudos colocam Angola nas piores posições mundiais em número de amputados. A situação da saúde pública, da educação e do acesso a serviços básicos é temerária. O nível de emprego é ainda insuficiente, sendo que o setor informal corresponde a quase 60\% da economia (Bauer and Taylor 2005, I4I, I47). Na esfera da justiça, a Suprema Corte prevista constitucionalmente foi estabelecida somente em 2008 . As dificuldades afetam inclusive a justiça comum, que sofre de falta de quadros e baixa remuneração. 
lado, direitos políticos foram ampliados desde o Acordo de Bicesse de maio de I99I, possibilitando o estabelecimento de reformas constitucionais e de eleições multipartidárias, porém apenas parcialmente respeitadas. ${ }^{4 \mathrm{I}}$ Após a guerra civil, com a necessidade de acomodação das forças políticas, uma nova eleição legislativa para a Assembleia Nacional (parlamento unicameral) somente ocorreu em setembro de $2008.4^{2}$ Não obstante, a identidade nacional tem sido aos poucos reconstruída. A unidade é amparada pelo papel das políticas de construção de um Exército nacional integrado e educado na língua oficial e nas tradições cívicas.

\section{As Relações Estado-Sociedade}

Ainda que reformas constitucionais e políticas tenham sido implementadas desde o início da década de I990, o MPLA continua possuindo dominância absoluta no parlamento e centraliza grande parte das decisões políticas no presidente. Segundo Birmingham (2002, I77), "from being a single party state with a disaffected opposition thinly scattered in the provinces and abroad, Angola became a presidential state in which power emanated from the palace". Além de apontar postos nos ministérios, o presidente assegurou a prerrogativa de apontar os governadores das i 8 províncias do país, controlando o Executivo nacional e garantindo a dominância do MPLA.

O principal dilema da relação Estado-sociedade baseou-se na continuidade da insurgência armada da UNITA. Após o fracasso do Acordo de Lusaka em pacificar Savimbi, a guerra foi retomada em I998.43 Se a UNITA já havia sido derrotada em termos convencionais, em 2000 , a adoção de táticas de guerrilha pelo grupo insurgente trouxe um impasse ao conflito, que só foi rompido em fevereiro de 2002, com a morte de Jonas Savimbi em combate

4I O período entre I99I e I992 era de grande euforia, o que pode ser observado pelo número de eleitores (9I\% do eleitorado) que participou das eleições legislativas de setembro de I992. Entretanto, os resultados da eleição presidencial (40\% para Savimbi e 49\% para Dos Santos) não foi satisfatórias ao líder da UNITA, que abandonou o segundo turno e retornou à luta armada.

42 O MPLA obteve I9I de I20 assentos (8I,64\% dos votos), enquanto a UNITA (agora reconsolidada sob a liderança de Isaias Samakuva) foi o segundo partido mais votado, garantindo apenas I6 assentos (I0,39\% dos votos) (EISA 2009). As eleições presidenciais agendadas para 2009 foram adiadas devido à reforma constitucional de 2010 e a mudança das regras para a eleição do presidente. A nova Constituição estabeleceu que o presidente torna-se automaticamente o líder do partido com maior bancada na Assembleia Nacional (AGO 20I0, art. IO9) (I)). 43 Após a assinatura do Acordo de Lusaka, a UNITA se dividiu em duas facções, a UNITA de Jonas Savimbi e a UNITA-Renovada de Eugênio Manuvakola (ex-secretário geral da UNITA). O último grupo assumiu as cadeiras da UNITA no parlamento e tornou-se o principal partido de oposição. Em dezembro de I998, a UNITA de Savimbi retomou a luta armada. 
e com a vitória militar das FAA. Consequentemente, o cessar-fogo formal foi estabelecido em Luena (4 de abril de 2002) e sucedido pela desmobilização da UNITA. Outra ameaça de segurança superada foi a presente no enclave de Cabinda (FLEC), desmobilizada em 2006. Por fim, o crime organizado é outro problema de segurança interna em Angola e envolve o tráfico de diamantes, de narcóticos e de armas leves. As principais redes foram estabelecidas durante o conflito contra a UNITA e as guerras nos Congos e continuam presentes nos dias atuais (Jane`s 2009, I6). A mobilização da sociedade civil é frágil, dada a preocupação fundamental com os meios de sobrevivência. Todavia, após a década de I990 restrições a ONGs foram abolidas e grupos religiosos e instituições liberais se constituíram com plataforma de oposição ao governo. Como resposta aos sinais de novas pressões o governo apoia o surgimento de organizações, como a Fundação Eduardo dos Santos (FESA), que lhe servem como ponto de suporte. O incremento das capacidades estatais a partir de meados da década de I990 e a grande oscilação das pressões à elite governante no período (altas pressões iniciais, seguidas pela distensão das ameaças) podem auxiliar a explicar as decisões das EPDE por mudanças na política externa regional.

\section{Elites e Política Externa Regional em Angola (1989-2010)}

Após o desgaste de décadas de guerras interna e externa, os anos I990 presenciaram a redução do poder do MPLA como instituição definidora de política externa. Concomitantemente à dissolução da estrutura marxista-leninista do Estado e a perda relativa de espaço pelo partido, o presidente acabou adquirindo papel crescente, quase exclusivo na definição de política externa. O palácio Futungo de Belas recebia, contudo, inputs de atores relevantes. Enquanto o Ministério de Relações Exteriores enfrentava grandes dificuldades, com uma burocracia mal treinada e pouco efetiva, os militares acabaram angariando grande respeitabilidade na política externa. Trata-se de uma instituição nacional com grande capacidade e competência burocrática, adquiridas ao longo dos anos de investimento nas décadas de i980 e i990 (média de $25 \%$ do orçamento). Sua credibilidade em negociações regionais levou a soldados-diplomatas adquirirem posições de embaixadores em locais importantes como Nova Iorque (Gal. Antonio Fanca "Ndalu", ex-comandante do Estado Maior) e África do Sul (Gal. Alexandre Rodrigues Kito, ex-ministro do interior) (Malaquias 2002, I4).

A preponderância de Dos Santos e a participação ativa dos militares conferiram à política externa a prioridade crescente da segurança estatal, competindo com a valorização da segurança regional. A reduzida competição 
entre elites fez das ações armadas de UNITA e da FLEC a principal preocupação do Estado durante todo o período. O foco era extrapolar as fronteiras nacionais e procurar atacar as fontes de amparo desses grupos armados. Após a derrota dos grupos rebeldes, as elites políticas parecem voltar-se para a resolução de problemas internos ligados à reconstrução das capacidades do Estado e o desenvolvimento econômico. Sua política regional, como consequência foi derivada deste objetivo maior: engajar-se no sistema de forma a garantir estabilidade interna.

Portanto, a política regional angolana do período pós-Guerra Fria tem se focado em situações que se vinculam diretamente aos problemas internos do país, relacionados à construção do Estado. A sua participação nas guerras da RDC e do Congo-Brazzaville (relacionada à ampliação das fronteiras regionais), e a aliança com a Namíbia e a penetração no território da Zâmbia (para suprimir forças da UNITA) são indicadores que parecem sustentar esta percepção (Khadiagala 200I, I47). Além disso, a parceria com a China e os EUA tem espelhado essa postura de utilizar a diplomacia de forma pragmática como facilitador do processo de construção do Estado, atualmente baseado no crescimento econômico centrado no alto fluxo de comércio de commodities e em investimentos em infraestrutura. Tal posição converge com a ideia de que há a necessidade de "a form of Marshal Plan for the reconstruction of the country, which, in many respects, must involve the participation of the international community" (Dos Anjos 2008, 10).

Sendo "a desconfiança uma característica marcante nas relações entre indivíduos e instituições" (José 20II, IO3), as ações angolanas no sistema regional objetivam, prioritariamente, a própria estabilidade e sobrevivência. Houve o reconhecimento da clara "connection between domestic security, regime survival, and regional and international politics" (Malaquias 20II, 5-6). Não obstante, Angola logrou em todo o período grande vitória em sua política externa e a transformação relativa do sistema regional para a sua própria segurança, de um ambiente cercado por inimigos à uma região relativamente estável para concretização de seus interesses.

\section{Elites e Política Externa Regional em Dos Santos, período de transição (1989-2002)}

Com a liberalização do regime e a transição ideológica do MPLA, o presidente José Eduardo dos Santos assumiu papel central na formulação e execução da política externa. Além disso, o exército se tornou "an executor of the government's foreign policy, particularly when it involves the use of force at the regional level" (Malaquias 2002, I7). Não obstante, o MPLA, embora tenha 
reduzido o seu papel relativo na formulação da política externa, atuou como importante articulador da recuperação da imagem internacional de Angola. ${ }^{44}$

Os principais desafios à segurança da EDPE estiveram relacionados às pressões internas da guerra civil. Primeiramente, importa ressaltar que a transição do conflito proxy para um conflito interno foi gradual e limitada, dada a continuidade da participação e apoio externo de lado a lado. Entretanto, gradualmente o foco do conflito foi transferido para as dinâmicas domésticas. Em I989, Dos Santos sinalizava renovada disposição em iniciar o second track de negociações do conflito em Angola, ou seja, a fase de resolução do conflito doméstico. A redução de pressões regionais, combinada com maior engajamento extrarregional (EUA, URSS e Portugal) e desafios domésticos agudos (crise econômica) abriu o caminho para o maior comprometimento com um acordo equilibrado, firmado em Bicesse em abril de I991 ${ }^{45}$ (Malaquias I999, 33-36). Todavia, o Acordo de Bicesse confirmou apenas a tendência do fim do estágio proxy da guerra de Angola e não a acomodação do conflito interno. ${ }^{46}$ Já com o Protocolo de Lusaka (novembro de I994), a comunidade internacional assumiu maior participação no processo e arranjos de power-sharing foram adotados (Stedman, Rotchild, and Cousens 2002)47. Todavia, a guerra civil foi restaurada quatro anos depois, graças a renovada capacidade de financiamento da UNITA mediante o tráfico de diamantes. Savimbi estava obstinado a assumir o poder e não vislumbrava solução possível senão a vitória militar.

Como resposta, a política externa regional de Angola no período ad-

44 O secretário-geral do MPLA, João Lourenço, assumiu função pró-ativa na política externa e procurou incrementar o prestígio do partido. Visitou diversos países na década de I990 (EUA, China, Portugal, França, África do Sul, Israel) para reafirmar relações e garantir credibilidade para o processo de paz angolano.

45 Em 25 de abril de 1990 o governo de Dos Santos anunciou que entraria em negociações diretas com a UNITA, mediadas por Portugal. EUA e URSS anunciaram para Savimbi e ao ministro de relações exteriores de Angola, Pedro de Castro Van Dunem, que não proveriam mais apoio militar e financeiro aos seus aliados se a guerra continuasse. Finalmente, em 3I de maio de I99I o Acordo de Bicesse foi assinado. O acordo previa a transição democrática no país e o fim do apoio externo militar das partes em conflito (Bekoe 2008).

46 As eleições supervisionadas internacionalmente ocorreram em I992, mas o seu resultado não foi reconhecido pela UNITA, fato que trouxe o retorno do conflito ao país em apenas I8 meses após a assinatura do acordo. Savimbi reuniu seus generais que estavam integrando-se ao novo exército e os enviou novamente à guerra, controlando três quartos do interior do país (Bauer and Taylor 2005, 150). Entretanto, pressões externas levaram Savimbi de volta à mesa de negociações em I993 e em I994 um novo acordo foi assinado, mediado pela ONU.

47 A UNITA desarmaria seus combatentes, que em seguida seriam anexados ao exército nacional e se comprometeria em devolver suas áreas de administração ao governo central (Hodges 200I, 6I). O MPLA ofereceria cargos no governo e no exército nacional, com o objetivo de criar um Governo de Unidade e Conciliação Nacional (GURN), além de conceder a posição de vice-presidente para Savimbi. O cessar-fogo seria observado por 7.500 tropas da ONU. 
quiriu caráter militante contra a UNITA e o estabelecimento de um princípio prioritário de segurança coletiva na região, ao menos nas fronteiras do norte. Ações diplomáticas ativas visavam abalar a credibilidade de Savimbi. ${ }^{8}$ As ações regionais de Angola continuavam estabelecendo uma relação direta entre ordem regional e estabilidade doméstica e com a crescente acomodação das fronteiras do sul, a atuação impetuosa de Angola tomou contornos nas fronteiras regionais do norte. Empreendeu ações militares em I997, para derrubar o regime de Mobutu no Zaire e Pascal Lissouba no Congo-Brazaville (ambos apoiadores da UNITA); e, em I998, para defender o regime de Laurent Kabila na RDC. Na Primeira Guerra do Congo, Angola tinha interesses muito particulares para se engajar. Tratava-se de capturar Joseph Savimbi, desmobilizar o exército secreto da UNITA, que voltou à guerra após as conciliações de I994 e I995 (acreditava-se que I5 mil homens estavam em operação no Zaire), e quebrar suas redes comerciais de diamantes. Angola teve grande protagonismo, cedendo apoio logístico e assistência na captura de Kinshasa. ${ }^{49} \mathrm{Na}$ Segunda Guerra do Congo, as ações angolanas reproduziram o princípio da segurança regional e a defesa da soberania jurídica e empírica de países aliados. Angola possuía interesses genuinamente securitários para engajar-se no conflito ${ }^{50}$ embora o engajamento tenha sido lucrativo. ${ }^{\text {I }}$ Apesar

48 João Lourenço, por exemplo, realizou encontros com o presidente Mbeki em janeiro de 2000 para apresentar a insatisfação de Angola com operações desestabilizadoras perpetradas no país por sul-africanos. O Fowler Report sugeriu ainda que a UNITA continuava a obter armas da África do Sul, acusando uma delegação da UNITA de viajar ao país em agosto de I999 e obter uma bateria antiaérea de $35 \mathrm{~mm}$ (UN 2000, para. 30). Além disso, Angola declarou boicote ao $36^{\circ}$ encontro da OUA em Togo, devido ao apoio deste país à UNITA (Malaquias 2002, I7).

49 Angola decidiu entrar na guerra em dezembro de 1996 e enviou observadores à região de Bukavu (leste do Zaire). Em janeiro e fevereiro de 1997 diversos cargueiros angolanos produzidos na Rússia levavam soldados e armas de Luanda a Kigali (Malaquias 2002, 23; McKinley I997). Em fevereiro de 1997, chegaram a Goma e Bukavu 2.000 a 3.000 tropas dos Tigres de Katanga , vindos de Angola e passando por Ruanda. Houve ainda, em abril de I997, um reforço das tropas de Angola. Nesse mês foi travada a última grande batalha da guerra (Batalha de Kenge), quando forças combinadas zairianas (inclusive elementos da Division Spéciale Présidentielle de Mobutu) e da UNITA foram derrotadas. A importância da intervenção de Angola foi tamanha que, se, em quatro meses de guerra, Kabila só foi capaz de obter I/20 do Zaire, com Angola o resto do país foi conquistado em três meses (Turner 2002, 83).

50 Primeiramente, tinha-se um débito com os katangueses que haviam lutado na Primeira Guerra do Congo em apoio ao MPLA. Em segundo lugar, Angola percebia a necessidade de travar uma nova guerra particular com a UNITA, que se aproximava de Uganda e Ruanda - com viagens do vice-presidente da organização a Kigali e de Savimbi a Uganda. Dessa forma, Angola tinha todos os interesses em evitar que a RDC se tornasse novamente um recanto de linhas de suprimento (diamantes) para a UNITA. Em terceiro lugar, Angola queria proteger seu próprio território (principalmente a região de Cabinda, rica em petróleo e desconectada do território angolano) - haja vista que Uganda e Ruanda enviaram tropas a Bas-Congo, no jardim angolano.

5I Acordos entre o governo de Laurent Kabila e o de José Eduardo dos Santos permitiram o 
do reduzido número e pobre estado de manutenção das forças empregadas no Congo ( 2,5 a 5 mil homens), seu poder aéreo foi uma vantagem decisiva na guerra e garantia da defesa de Kinshasa (Reyntjens 2009, I99; ICG 2000, 4; Turner 2002). A ação impetuosa de Angola em defesa de uma ordem regional que afiançasse a sua segurança interna estava, contudo com os dias contados. A concentração dos esforços para a solução militar do conflito interno e a acomodação das ameaças percebidas na região, reduziriam seu ímpeto de ação no período seguinte.

\section{Elites e Política Externa Regional em Dos Santos, pós-Guerra Civil (2002- 2010)}

Com a resolução de quase trinta anos de guerra civil e regional, Angola emergiu como a principal vencedora do conflito, tendo derrotado seus principais rivais na região. Esse resultado, como demonstrado acima, foi acompanhado por uma reestruturação quantitativa e qualitativa das FAA que posicionou o Estado, em termos de capacidades militares, como uma potência regional emergente na África Austral. Por outro lado, as instituições políticas angolanas continuam arcaicas e sua estrutura econômica continua sendo baseada amplamente na exportação de recursos naturais. Ademais, as características da política externa de Angola não parecem indicar um interesse do país em assumir um papel de liderança no sistema regional ou em efetivar mudanças radicais na ordem sistêmica. De fato, a excessiva ênfase dada por Luanda à manutenção da segurança interna e pressões externas reduzidas resultam em uma política externa de ímpeto declinante. Cada vez mais, Angola apenas interfere na política regional caso sua estabilidade interna esteja em jogo. Como as pressões prexistentes tenderam ao declínio a sua atuação tem seguido cada vez mais esse caminho.

Em termos formais, os objetivos da política externa angolana são amplos e priorizam, entre outros temas, "[...] o reforço da identidade africana e o fortalecimento da acção dos Estados africanos em favor da potenciação do património [sic] cultural dos povos africanos”. Ademais, o país visa à “[...] participação, no quadro das organizações regionais ou internacionais, em forças de manutenção da paz e em sistemas de cooperação militar e de segurança colectiva [sic]" (AGO 20I0, Art. 3, grifo meu). Alguns autores inclusive sa-

estabelecimento de uma joint venture entre Sonangol (60\%) e COMIEX $(40 \%)$ para o fornecimento de gasolina à RDC e a exploração conjunta futura de petróleo na costa dos dois países. Além disso, o governo angolano "demandou compensações, na forma de concessão de diamantes, para despesas militares incorridas ao auxiliar o governo congolês" (Nest 2006, 5I, tradução minha). 
lientam o papel proativo da diplomacia angolana na solução de problemas regionais. Isso consolida uma "imagem do país como parceiro para a estabilidade e segurança” (José 20II, II4,I22). Contribuiu para esta posição de prestígio, a diplomacia presidencial de José Eduardo dos Santos. O presidente possui "reconhecida liderança no continente, que tem servido para ampliar a credibilidade política do País e respaldar a confiança nas diretrizes e compromissos adotados pelo governo" (José 20II, I5I).

Todavia, os objetivos declarados continuam limitados, na prática, pelos interesses prioritários do governo do MPLA-PT com a manutenção da segurança interna do país e pelas reduzidas pressões externas para ação. Após 2002, a última pressão militarizada ao Estado e à elite política era a existente no enclave de Cabinda ${ }^{52}$ e o reposicionamento de capacidades militares e de inteligência autorizou ofensivas militares que resultaram na derrota da maior parte das forças da FLEC.53 Em que pese o fim dos conflitos internos, Angola fundamenta sua posição frente ao eixo securitário da ordem regional na segurança nacional. ${ }^{54}$ Exceção a esse perfil isolacionista pode ser percebida em situações recentes em RDC ${ }^{55}$ (além de Costa do Marfim e Guiné-Bissau) ${ }^{56}$ em

52 Cumpre lembrar e reiterar que o controle do histórico conflito na região já havia sido obtido com as intervenções angolanas na RDC (I997 e I998) e no Congo-Brazzaville (I997). Todavia, o separatismo retornou à agenda de segurança quando forças das FLEC pressionaram o governo de Portugal para facilitar a independência do enclave, mediante o sequestro de cidadãos portugueses. Como resposta, o MPLA, mesmo ressaltando que não cederia a independência do enclave, acenou disposição para negociar. Esta posição mais flexível foi abandonada em 2002, quando a desmobilização de tropas nos Congos e a vitória frente a UNITA possibilitaram o deslocamento de tropas para a supressão militar do separatismo.

53 No início de 2004 os rebeldes estavam praticamente derrotados, haja vista que bases militares e líderes da guerrilha foram capturados. A situação desencadeou tratativas de paz, a criação de um Fórum Cabindês para o Diálogo (FCD), a anistia de todos os insurgentes e a desmilitarização do movimento. $\mathrm{O}$ acordo de paz foi estabelecido em agosto de 2006 , com a diretiva de que o enclave se mantivesse como parte de Angola, admitindo-se um status especial.

54 Este conceito decorre da experiência histórica com a guerra civil, quando a maior ameaça para o Estado situava-se dentro de suas fronteiras. Na adoção do conceito procura-se evitar a formação de novas forças reivindicadoras de poder e consolidar o processo de construção do Estado.

55 Angola declarou, em agosto de 2006 , de que 30 mil tropas estavam preparadas na província angolana de Cabinda para serem utilizadas contra qualquer nova invasão ruandesa ao Congo (STRATFOR 2006). Isso ocorreu mesmo quando as ameaças da UNITA já haviam sido desmobilizadas.

56 O posicionamento enfático do governo angolano na crise eleitoral da Costa do Marfim em 2OII - a favor da estabilidade do governo Laurent Gbagbo e de uma solução dada pelos próprios países africanos com perfil pacífico e negociado - demonstrou interesses mais ambiciosos de Angola na política continental. Além disso, em março de 20II, Angola passou a comandar a missão de reforma das forças armadas de Guiné-Bissau (MISSANG), como parte de uma política, anunciada em 2009, que busca a criação de mecanismos que incrementem a segurança 
que o país buscou reafirmar uma posição alinhada à segurança regional. Entretanto, embora possam sinalizar uma eventual inflexão na política externa angolana, tais comprometimentos são ainda muito tímidos e não se consolidaram em qualquer dos casos. ${ }^{57}$ Como exemplo dessa postura hesitante, o presidente Dos Santos, ao elencar os princípios estruturantes da política externa angolana, em discurso no ano de 20II, menciona a integração regional apenas no décimo ponto e de forma muito genérica, sem explicitar a África Austral ou o continente africano (dos Santos 20II). Essa postura pode ser inclusive explicada pelas dificuldades ainda presentes para que Angola consiga projetar poder e angariar reconhecimento como líder regional.

Contudo, o relativo isolamento angolano prejudica a sua própria inserção internacional, já que "o aumento da capacidade de influência de Angola não pode ser alcançado por meio do isolamento ou da pretensa autossuficiência em recursos" (José 2OII, I23). Por outro lado, essa postura também elide a possibilidade, em curto prazo, de que sua ascensão à potência regional resulte em uma guerra hegemônica em busca de uma revisão da ordem regional (Castellano da Silva and Brancher 2015)..$^{8}$

Em síntese, a instabilidade das capacidades estatais do início da década de I990 e a retomada da luta armada pela UNITA foram respondidas com investimentos nas capacidades estatais coercitivas, em um ambiente de maior legitimidade do MPLA devido à relativa democratização política. A elite do MPLA, agora destituída do projeto marxista-leninista, continuava buscando a transformação da ordem regional, exceto pelo crescente alinhamento à ordem

regional na zona sob escopo do Conselho do Golfo da Guiné (José 20II, 205,254).

57 No caso da Costa do Marfim, o posicionamento angolano não logrou uma política articulada com demais países que compartilhavam sua posição em defesa do presidente Laurent Gbagbo, o que sinalizou limites ao reconhecimento da liderança angolana na política continental. Além disso, na situação da Guiné-Bissau, pressões internas e externas levaram o governo angolano ao encerramento de suas operações em io de abril de 20I2, abrindo caminho para a concretização do golpe militar de I2 de abril (UN 2OI2). Posteriormente, na RDC, Angola se veria relativamente deslocada das articulações diplomáticas que estabeleceram uma nova brigada de intervenção (FIB) da ONU no Congo em 20I3, força integrada por África do Sul, Tanzânia e Malaui, cujo mandato apresenta caráter ofensivo inédito.

58 Enquanto os esforços de reconstrução nacional estiverem amparados no alto crescimento econômico, Angola estará relativamente satisfeita com os limites da cooperação econômico-comercial da região e com as alternativas atuais de resolução de conflitos. Ressalta-se que Angola tem recorrentemente adiado a sua adesão à Zona de Livre-Comércio da Southern African Development Community (SADC) (VerAngola 20I4), mas não apresenta alternativa a este projeto (atualmente centrado na economia sul-africana). Tais pontos complementam-se com o incremento das relações do eixo Pretória-Luanda, fortalecidas com a ascensão do governo Jacob Zuma, que possui conexões históricas com Angola e que escolheu o país como destino de sua primeira visita oficial como presidente sul-africano em 20 Io. 
econômica fundamentada no mercado. A continuidade de altas pressões internas, vinculadas à ameaças externas, era respondida com grande ímpeto de ação na região, mediante uma visão de segurança regional, vinculada à defesa do próprio Estado. Após 2002, as reduções das ameaças internas e externas de segurança possibilitaram a diminuição das ambições regionais do país e a transferência do foco político para a reconstrução das capacidades internas, dados os desafios deixados pela guerra civil.

\section{CONCLUSÃO}

Entre 1975 e I988 a política externa regional de Angola foi assinalada por uma postura revolucionária, interessada em grandes transformações na ordem regional e atuava com grande ímpeto para a realização desse objetivo, inclusive meios militares diretos e indiretos. As origens dessa política externa situavam-se nas grandes ameaças internas e externas experimentadas pelo governo de perfil desenvolvimentista do MPLA, tanto durante a presidência de Agostinho Neto quanto na de José Eduardo dos Santos. Nesse último caso, as pressões tornaram-se ainda mais relevantes dados o avanço das ações desestabilizadoras da África do Sul e o fortalecimento da UNITA. A resposta regional ativa foi angariada por políticas de fortalecimento das capacidades estatais, mas sobretudo pelo grande apoio externo de Cuba, URSS e de países do Leste Europeu, mormente na esfera coercitiva. A posição revolucionária na região foi gradualmente reduzida com o prospecto de mudança da ordem regional e a prioridade de solução do conflito interno. Entre I989 e 2010 a política externa passou de um breve interregno isolacionista, em virtude das negociações de paz, para uma postura impetuosa na região com vistas a garantir a segurança regional como parte da sua própria segurança interna, dada a retomada da luta armada pela UNITA em fins da década de I990. O fortalecimento das capacidades estatais viabilizou a ação externa ativa, que se reduziu na medida em que as pressões externas e domésticas (grupos sociais insurgentes) entraram em declínio. A elite do MPLA mantém atualmente uma postura reformista, mas relativamente submetida à ordem vigente, já que se recupera dos quase trinta anos de guerra civil (excluindo-se os anos da guerra de libertação nacional).

Por fim, ainda resta um questionamento acerca do futuro: se a ordem regional era vista como diretamente relacionada às condições domésticas, qual será o perfil do posicionamento externo após a estabilidade interna? Ainda é cedo para avaliar se os interesses de Angola na ordem regional serão ou não modificados e se o seu ímpeto será mantido ou expandido. Contudo, à medida que haja desenvolvimento econômico e estabilização política interna 
Angola tende a dar mais atenção às dinâmicas regionais e incrementar o seu ímpeto de ação, assim como o fez a África do Sul após a acomodação de forças na transição do apartheid. Por outro lado, sua postura em relação ao status quo é atualmente muito mais alinhada à ordem liberal vigente, que pode favorecer elites econômicas e políticas. Portanto, embora a tendência de Angola seja atuar de forma mais ativa na região no futuro, seu alinhamento possivelmente colaborará com a manutenção do status quo, se não, com reformas pontuais.

\section{REFERÊNCIAS}

AGO. 20Io. Constituição Da República de Angola. Luanda: República de Angola. http://www.comissaoconstitucional.ao/pdfs/constituicao-darepublica-de-angola.pdf.

Bauer, Gretchen, and Scott D. Taylor. 2005. Politics in Southern Africa: State and Society in Transition. Boulder: Lynne Rienner Publishers.

Bekoe, Dorina. 2008. Implementing Peace Agreements: Lessons from Mozambique, Angola, and Liberia. New York: Palgrave Macmillan.

Billon, Philippe le. 200I. "Angola's Political Economy of War: The Role of Oil and Diamonds, I975-2000." African Affairs Ioo (398) (January I): 55-80. doi:ıo.Io93/afraf/I00.398.55. http://afraf.oxfordjournals.org/ content/100/398/55.abstract.

Birmingham, David. I992. Frontline Nationalism in Angola and Mozambique. New Jersey: Africa World Press.

2002. "Country Studies - Angola." In A History of Postcolonial Lusophone Africa, edited by Indiana University Press, I37-I84. Bloomington.

Brittain, Victoria. I996. Morte Da Dignidade: A Guerra Civil Em Angola. Lisboa: Dom Quixote, Lda.

Castellano da Silva, Igor. 20I2. Congo, a Guerra Mundial Africana: Conflitos Armados, Construção Do Estado E Alternativas Para a Paz. Porto Alegre: Leitura XXI/Cebrafrica /UFRGS. . 2015. "Política Externa Na África Austral: Causas Das Mudanças Nos Padrões de Cooperação-Conflito (I975-2010)." Phd thesis. Universidade Federal do Rio Grande do Sul, Porto Alegre, Brazil.

Castellano da Silva, Igor, and Pedro Txai Leal Brancher. 2015. "O Futuro Da África Austral: Consequência Da Expansão Das Fronteiras Regionais E Da Bipolaridade.” Revista Das Ciências Militares 9 (34): 33-49. 
Chan, Stephen. I990. "Foreign Policies in Southern Africa: Is a New Epoch Possible?" In Exporting Apartheid: Foreign Policies in Southern Africa, 1978-1988, edited by Stephen Chan, I26-I42. London: Macmillan Publishers.

Dos Anjos, Isaac Fransisco Maria. 2008. "Angola: On the Road of Reconciliation and National Reconstruction." In Foreign Policy and International Relations: Reflections of Diplomats, edited by Korwa G. Adar, Faten Aggad, and Biong Deng, I:3-II. Pretoria: AISA Monographs (v.I, n.I).

Dos Santos, José Eduardo. 20ir. “Discurso Do Presidente Da República de Angola Ao IV Conselho Consultivo Alargado Do MIREX.” Luanda: Embaixada de Angola em Portugal.

EISA. 2009. "Angola: 2008 National Assembly Election Results." Electoral Institute for Sustainable Democracy in Africa. http://www.content.eisa. org.za/old-page/angola-2008-national-assembly-election-results.

Global Witness. 2002. "A História Devastadora Das Indústrias Petrolíferas E Bancárias Na Guerra Privatizada de Angola.”. Global Witness. https:// www.globalwitness.org/archive/all-presidents-men/.

Hodges, Tony. 200I. Angola From Afro-Stalinism to Petro-Diamond Capitalism. Bloomington: Indiana University Press. 2004. Angola: Anatomy of an Oil State. Oxford: James Currey.

ICG. 2000. "(International Crisis Group). Scramble for the Congo: Anatomy of an Ugly War." ICG Africa Report 26.

IISS. 2004. The Military Balance 2003-2004. London: Routledge.

Jane`s. 2009. "JANE'S Country Profile: Angola." Acervo do Núcleo de Estratégia e Relações Internacionais (NERINT).

José, Joveta. 20ıг. "A Política Externa de Angola: Novos Regionalismos E Relações Bilaterais Com O Brasil.”. Phd thesis. Universidade Federal do Rio Grande do Sul, Porto Alegre, Brazil.

Keller, Edmond J. I987. "Afro-Marxist Regimes." In Afro-Marxist Regimes: Ideology and Public Policy, edited by Edmond J. Keller and Donald Rothchild, I-24. Boulder and London: Lynne Rienner Publishers.

Khadiagala, Gilbert M. 200I. "Foreign Policy Decisionmaking in Southern Africa's Fading Frontline." In African Foreign Policies: Power and Process, edited by Gilbert M. Khadiagala and Terrence Lyons, I3I-I58. London: Lynne Rienner Publishers.

Klare, Michael T. I985. "Low-Intensity Conflict; the New U.S. Strategic Doctrine.”. The Nation, December 28. http://www.highbeam.com/ 
doc/IGi-40727i8.html.

Leogrande, William. I980. Cuba's Policy in Africa, 1959-1980. Berkeley: University of California.

Malaquias, Assis. I999. "Angola: The Foreign Policy of a Decaying State." In African Foreign Policies, edited by Stephen Wright, 23-42. Boulder: Westview Press.

- 2000. "Ethnicity and Conflict in Angola: Prospects for Reconciliation.” In Angola's War Economy: The Role of Oil and Diamonds, edited by Jakkie Cilliers and Christian Dietrich, 95-II3. Pretoria: ISS. http://www.issafrica.org/publications/books/oI-nov-200o-angolaswar-economy.the-role-of-oil-and-diamonds-j-cilliers-c-dietrich-eds. . 2002. "Dysfunctional Foreign Policy: Angola's Unsuccessful Quest for Security since Independence." In Globalization and Emerging Trends in African States' Foreign Policy-Making Process: A Comparative Perspective of Southern Africa, edited by Korwa Gombe Adar and Rok Ajulu, I3-33. Burlington, VT: Ashgate.

—_. 20II. "Angola's Foreign Policy: Pragmatic Recalibrations." 84. Occasional Paper. Johannesburg: SAIIA.

Marcum, John A. I987. “The People's Republic of Angola: A Radical Vision Frustrated." In Afro-Marxist Regimes: Ideology and Public Policy, edited by Edmond J. Keller and Donald Rothchild, 67-84. Boulder and London: Lynne Rienner Publishers.

Mazrui, Ali A. 20I0. "Procurai Primeiramente O Reino Político..." In História Geral Da África, VIII: África Desde 1935, edited by Ali A. Mazrui and Christophe Wondji, I25-I49. Brasília: UNESCO.

McKinley, James C. Jr. I997. “Congo’s Neighbors Played Crucial Role in Civil War.” New York Times, May. http://www.nytimes.com/I997/05/22/ world/congo-s-neighbors-played-crucial-role-in-civil-war.html.

Minter, William. I994. Apartheid's Contras: An Inquiry into the Roots of War in Angola and Mozambique. London: Zed Books.

Nest, Michael. 2006. “The Political Economy of the Congo War." In The Democratic Republic of Congo. Economic Dimensions of War and Peace, edited by Michael Nest, François Grignon, and Emizet Kisangani. London: Lynne Rienner Publishers.

Reyntjens, Filip. 2009. The Great African War. New York: Cambridge University Press.

Shubin, Vladimir. 2008. The Hot "Cold War": The USSR in Southern Africa. $\mathrm{I}^{\text {st }}$ ed. London: Pluto Press. 
Stedman, Stephen Joh, Donald Rotchild, and Elizabeth Cousens. 2002. Ending Civil Wars: The Implementation of Peace Agreements. Boulder: Lynne Rienner Publishers.

STRATFOR. 2006. "Angola: Ready to Intervene in the DRC for Kabila." STRATFOR. http://www.stratfor.com/memberships/41075/angola_ ready_intervene_drc_kabila.

Turner, Thomas. 2002. "Angola's Role in the Congo War." In The African Stakes of Congo War, edited by John F. Clark. New York: Palgrave Macmillan.

Tvedten, Inge. I997. Angola: Struggle for Peace and Reconstruction. Boulder: Westview.

UN. 2000. "S/2000/203. Final Report of the UN Panel of Experts on Violations of Security Council Sanctions Against UNITA." New York: United Nation, Io March. https://www.globalpolicy.org/globaltaxes /4I606-final-report-of-the-un-panel-of-experts.html. . 20I2. "Guinea-Bissau: July 20I2 Monthly Forecast." United Nations. Security Council Report. http://www.securitycouncilreport.org/ monthly-forecast/20I2-07/lookup_c_glKWLeMTIsG_b_8ı9I98I. php.

VerAngola. 20I4. "Angola Adia Adesão À Zona Comércio Livre Da SADC." VerAngola.net. Accessed January 6. http://www.verangola.net/Artigos/ Angola-adia-adesao-a-zona-comercio-livre-da-SADC=002962.

Visentini, Paulo Fagundes. 2012. As Revoluções Africanas. São Paulo: Editora UNESP. 2013. "As Revoluções Anticoloniais Da África Negra." In Revoluções E Regimes Marxistas: Rupturas, Experiências E Impacto Internacional, 338-389. Porto Alegre: Leitura XXI.

Wolfers, Michael, and Jane Bergerol. 1983. Angola in the Frontline. London: Zed Press. 


\section{RESUMO}

O artigo aborda a política externa de Angola para a África Austral (I975-20I0) e avalia a sua posição frente à ordem do sistema regional em transformação e as explicações para esse comportamento, vinculadas ao processo de construção do Estado e aos interesses e segurança das elites definidoras de política externa.

\section{PALAVRAS-CHAVE}

Angola; Política Externa; África Austral.

Recebido em 15 de julho de 2015. Aprovado em 24 de agosto de 2015. 


\section{REFLEXÕES SOBRE A EMERGÊNCIA CHINESA}

\section{Cesar Augusto Lambert de Azevedo'}

\section{Introdução}

Em maio de 20I5, o Brasil recebeu uma comitiva da República Popular da China (RPC) liderada pelo primeiro-ministro Li Keqian. O resultado imediato foi a assinatura de um Plano de Ação Conjunta para o período de 2015 a 202I, composto de 35 acordos de cooperação². Vários segmentos foram contemplados: agricultura e pecuária; ciência e tecnologia (C\&T); comércio; comunicações; energia; esportes; infraestrutura; meio ambiente; planejamento; e relações exteriores. Provavelmente o acordo que requererá estudos mais densos e de maior quantidade de recursos refere-se ao projeto ferroviário, por meio do qual se pretende ligar o porto de Açu, no norte fluminense com o de Ilo, no Peru. A sua realização poderá propiciar o escoamento de cargas de baixo valor unitário, como grãos, das áreas produtoras do centro-oeste brasileiro aos portos chineses, como o de Xangai. Para tanto, foi assinado o memorando de entendimento sobre estudo de viabilidade desse Projeto Ferroviário Transcontinental.

Outros três acordos relevantes para este artigo são os que se referem: à exportação de produtos pecuários brasileiros; ao financiamento para a empresa Petróleo Brasileiro Sociedade Anônima - Petrobrás; e à exportação de minério de ferro. O primeiro permite a retomada das importações chinesas de carne bovina brasileira por meio de normas mais aceitas no campo da saúde animal. O segundo financia a petroleira brasileira para explorar campos

I Professor na Faculdade de Campinas (FACAMP).Possui graduação em Ciências Navais pela Escola Naval e doutorado em Política e Estratégia Marítima pela Escola de Guerra Naval e em Ciência Política pela Universidade de São Paulo, em área temática de Relações Internacionais. Pesquisa políticas externas chinesa e norte-americana. E-mail: csazv@terra.com.br 2 Conforme o Portal Planalto, de 20/05/2015, com matéria dedicada à ampliação chinesa de investimentos no Brasil. 
marítimos em águas profundidas. Neste caso, a contrapartida poderá ser o fornecimento de petróleo à RPC, se tomarmos como modelo acordo anterior firmado em 2009: financiamento chinês de US\$ io bilhões e contrapartida de fornecimento de 150.000 barris por dia (bl/d) em 2009 e de $200.000 \mathrm{bl} / \mathrm{d}$ nos nove anos seguintes ${ }^{3}$. O terceiro acordo diz respeito a cooperações financeira e operacional no setor de mineração, a envolver a Companhia Vale do Rio Doce (Vale) e entidades chinesas. O valor total dos investimentos chineses nos 35 projetos é estimado em cerca de US\$ 53 bilhões, para um recorte temporal não determinado.

Não é valor trivial haver acordos bilaterais com alcance econômico de tal envergadura. Independentemente do período temporal a ser visualizado para o amadurecimento dos projetos, os desembolsos certamente acontecerão na medida em que os diferentes estudos mostrarem sua viabilidade, em especial a econômica. O projeto da ferrovia transcontinental, por exemplo, exigirá cuidadosos estudos de impacto ambiental e a elaboração dos consequentes relatórios de impacto do meio ambiente (EIA-RIMA). Esses estudos poderão determinar alterações de trajetos inicialmente estimados, transferência de populações (até mesmo de tribos indígenas, algumas ainda não estudadas), e obras de arte em engenharia para que se permita a transposição de largos rios da bacia amazônica. Considere-se, ainda, que o trabalho será realizado, em grande parte, no bioma amazônico onde, segundo Diegues (2002, 73) o clima é quente e úmido com temperatura média anual entre $24^{\circ}$ centígrados (C) e $26^{\circ} \mathrm{C}$ e média de precipitação de chuvas anual entre 2000 milímetros $(\mathrm{mm})$ e $3000 \mathrm{~mm}$. Tais características exigirão soluções técnicas próprias para a implantação de uma via permanente segura e estável, e orçamento realista.

Embora não tenha sido detalhado o acordo de financiamento à Petrobrás, o modelo adotado pela RPC compromete as empresas estrangeiras a fornecerem petróleo para a RPC no período que for acordado. Visentini $(2013,72)$ identifica um "modelo angolano" que foi adotado por outros Estados africanos. Também ali é determinada a contrapartida em matérias primas à guisa de compensação do investimento realizado. A seguir esse modelo, a operacionalização deste acordo referente à Petrobrás contribuirá para que a $\mathrm{RPC}$ possa dispor de energia fóssil para os seus diversos fins. A metodologia de operacionalização do modelo é burocraticamente simples e enfatiza setores de infraestrutura, produção e abertura de vagas para universitários em instituições chinesas. Segundo Brautigam (2009, II), no caso das obras de infraestrutura, a ajuda chinesa normalmente sinaliza com abertura de postos de

\footnotetext{
3 De acordo com o artigo Latin America and China's 'New Normal'- Analysis, publicado no sítio Eurasia Review, e com Patrick Howlett-Martin no seu artigo Chine-Brésil, une aliance fragile, publicado em Monde Chinois.
} 
trabalho de baixo nível de qualificação para os nacionais locais. Os postos que exigem formação sofisticadamente qualificada são destinados aos chineses para o gerenciamento das obras e a utilização de máquinas e equipamentos chineses. Esse é o modelo adotado pela RPC nos países africanos. Compreende-se a metodologia aplicada nesses países que são pouco dotados de parques industriais. Seria tal modelo também aplicado pelos chineses no Brasil?

No caso da Vale, a continuação do fornecimento de minério de ferro aos chineses garantirá a estes a matéria-prima necessária à manutenção do funcionamento do seu parque industrial. E esse parque industrial requer energia para que o minério seja transformado em produtos diversos. A preocupação do governo chinês com fornecimento de minério de ferro não é recente. Howllet-Martin, no artigo citado, lembra os investimentos chineses em 2005 de US\$ I, 5 bilhões do grupo Baosteel no Maranhão; e outro de US\$ 3 a US $\$ 4$ bilhões da China International Trust Investment Corporation para ampliação do porto de Itaqui, também no Maranhão, juntamente com infraestrutura ferroviária para transportar soja dos estados do Piauí e Maranhão. Isto é, as iniciativas chinesas visam dotar as regiões, do seu interesse, de infraestrutura adequada para o escoamento de produtos primários necessários à satisfação da demanda interna da RPC. Em que medida essas iniciativas são estrategicamente úteis para o Brasil? Em que medida elas se diferenciam de outras pretéritas realizadas por europeus ao longo dos séculos XIX e XX?

Este artigo procurará responder a essas perguntas a partir da análise da motivação chinesa em busca das commodities: grãos, petróleo e minério de ferro. Para tanto, identificará fontes de dados que possam apontar para elementos que ajudem a explicar essa busca. Após, fixar-se-á nas recentes iniciativas governamentais chinesas que contribuam para a construção de argumentos necessários à demonstração da Grande Estratégia ${ }^{4}$ adotada pela RPC nas relações com os parceiros internacionais. Para tanto, há que se identificar os objetivos nacionais estratégicos chineses que justifiquem essa Grande Estratégia. Procurar-se-á reconhecer eventuais dissimetrias interpretativas chinesas respeitantes aos vizinhos, especialmente em áreas marítimas. E, aqui, serão abordados, apenas resumidamente, constrangimentos e parcerias experimentados pela RPC relacionados a poderes exógenos à região que possam contribuir para a análise.

Dado que o sistema político da RPC é caracterizado por um partido

4 Grande estratégia pode ser definida como um "projeto nacional de longo prazo dedicado aos aspectos de segurança nacional”, conforme Moura (20I4, II2). Depreende-se, portanto, que a grande estratégia envolve um complexo de iniciativas ligadas a objetivos nacionais vitais à sobrevivência de uma nação. 
hegemônico5 , o Partido Comunista Chinês (PCCh), as decisões estratégicas são tomadas em nível de Estado, este tomado como referência neste artigo. Não seguirá, contudo, uma linha que privilegie o realismo político fundado no poder. Isto porque a busca chinesa pela satisfação de necessidades fundamentais - alimentos e energia (o minério de ferro depende de energia para a sua transformação) - por meio de acordos, procura comungar interesses comuns com parceiros. Logo, essa busca tem na cooperação a pedra angular na construção das parcerias. Afinal, um ambiente externo politicamente estável é determinante para a RPC continuar a receber os produtos vitais à sua sobrevivência. A cooperação determina reciprocidade, o que normalmente exige a retirada de barreiras alfandegárias ou não tarifárias ${ }^{6}$. A complementaridade pode ser aceitável, mesmo se a cooperação for qualitativamente assimétrica por exemplo, commodities por manufaturados. Mas pode ser percebido como inaceitável se um dos lados entender que o seu parque industrial é neutralizado pela concorrência do parceiro. Motiva, assim, que se examine as relações sino-brasileiras. Por fim, são apresentadas as considerações finais.

\section{Gênese da Emergência}

Os chineses constituem civilização milenar. A história chinesa ensina que as maiores preocupações dos governantes estavam na oferta de alimentos e na sua distribuição à população, além da proteção territorial frente aos povos do entorno. Confúcio7, nos Analetos (I997, 9I) recomendava: "Aquele que administra os negócios públicos deve cuidar que não faltem víveres, que as forças militares sejam suficientes e que o povo nele confie". Provavelmente, essa recomendação de Confúcio teria relação com a escassez de alimentos que frequentemente ocorria em face de catástrofes naturais e de guerras. E, apesar de ser um pensador que se preocupava com a paz nas relações sociais, não desconhecia a importância da defesa. Afinal, parte da sua vida corresponde a era dos Reinos Combatentes, entre 403 antes de Cristo (a.C.) е 22 I a.C. quando a instabilidade política e a escassez de alimentos afligiam as populações.

\footnotetext{
5 O termo Hegemonia tem aqui o sentido de supremacia da capacidade intelectual e moral, em virtude do PCCh ser formalmente aceito como guia legítimo do povo.

6 As barreiras não tarifárias dizem respeito a restrições ao comércio internacional, geralmente tomadas unilateralmente, tais como quotas e licenças de importação, medidas sanitárias e fitossanitárias e medidas anti-dumping social ou tecnológicas. Há vasta literatura sobre o tema; pode-se sugerir Foschete (200I) e Thorstensen (200I) pela objetividade na abordagem.

7 Confúcio teria vivido de 55i a.C. a 479 a.C., segundo Fairbank e Goldman (2006, 64) e Cheng $(2008,65)$. Esta afirma que o nome Confúcio é uma latinização efetuada pelos jesuítas na China de ideogramas que tem som de Konfuzi (Mestre Kong).
} 
É compreensível Swaine e Tellis $(2000, \mathrm{x})$ defenderem que, ao longo da história chinesa, a Grande Estratégia tem perseguido três objetivos estratégicos inter-relacionados: preservação da ordem doméstica e do bem estar do povo em face dos diferentes constrangimentos sociais; defesa contra persistentes ameaças externas à soberania e integridade territorial; e obter e manter influência geopolítica ao longo da extensa fronteira. Pode-se afirmar que uma poderosa fonte de instabilidade social está na escassez de alimentos. Para uma população que mantem quantitativo elevado, a preocupação dos governos com a sua produção é especial. Acresça-se a este fator a limitação de terras agricultáveis ser, aproximadamente, de I2\% do território da RPC, cujo total é de $9.600 .000,5$ quilômetros quadrados $\left(\mathrm{km}^{2}\right)^{8}$. A área agricultável é a mesma há milênios, o que exige manejo do solo cada vez mais acurado.

Com efeito, a análise de Naughton $(2007,35$ et seq.) respeitante à economia chinesa entre II27 e I9II identifica, para parte desse período, iniciativas sofisticadas que redundaram em elevada produtividade agrícola. No período, segundo ele, cerca de $90 \%$ da população sínica vivia no meio rural. Assim, a produção era extensiva em mão-de-obra empregada em pequenos lotes ${ }^{9}$. A sofisticação baseava-se em três fatores: variedades de sementes selecionadas; fertilização orgânica; e irrigação. Durante a dinastia Song (II27I279) conseguiu-se crescimento mais rápido do arroz, de modo a que fossem obtidas duas ou três colheitas por ano, por unidade de área. A fertilização orgânica empregava estrume animal e humano, misturado a lodo e algas. O sistema de irrigação permitia aos trabalhadores controlar adequadamente a quantidade de água, de sorte a se obter boas colheitas. Uma rede de canais artificiais foi desenvolvida para permitir a eficiente distribuição tanto dos insumos agrícolas quanto da produção destinada aos silos públicos. Curvas de nível foram usadas em terrenos de topografia irregular.

Naughton avança informando que, por 400 anos, o sistema de produção agrícola chinês atendeu à demanda interna. Informa que a população era de 72 milhões de pessoas em I400 e, em I820, chegou a 38I milhões, o que corresponderia a $32 \%$ da população mundial. À época, o produto interno bruto (PIB) da China era cerca de I/3 do PIB mundial. A elevação quantitativa da população associada à deterioração do sistema agrícola ao longo do tempo, por manutenção insuficiente, gerou persistente redução na oferta de grãos. A preocupação histórica voltou a ocupar a agenda dos governantes, simultaneamente a outro fator: a chegada de mercadores europeus no século XIX, além de portugueses, espanhóis e holandeses que já se relacionavam com a China

8 Conforme o Instituto Nacional de Geografia e Estatística (IBGE).

9 Os lotes, conforme Fairbank e Goldman (op. cit., I67), teriam área de, aproximadamente, 2428 metros quadrados $\left(\mathrm{m}^{2}\right)$. 
desde o século XVI. Os ingleses, principalmente, manifestaram insatisfação com o tradicional método cash-and-carr ${ }^{10}$ adotado pela China, com o pagamento por meio de prata. Segundo Babones ${ }^{\text {II }}$, desde a década de 20 do século XVI até I640, os navios ibéricos transportaram cerca de I00.000 toneladas (ton.) de prata à China ${ }^{\mathrm{I} 2}$. Deve-se pontuar que ela não tinha desenvolvido uma economia industrial ${ }^{13}$; esta só foi implementada a partir de I9I2, já no período republicano. Dessas observações são tiradas duas conclusões parciais: a prata internalizada na China serviu, basicamente, para incrementar atividades agrícolas; e o aumento populacional chinês, ao longo dos últimos 500 anos, não pode ser creditado à industrialização, como normalmente se faz nas análises respeitantes aos países europeus.

As guerras do ópio são conhecidas da história. A sofisticada e orgulhosa civilização chinesa quedou-se ao Tratado de Nanjing, de I842. Segundo Spence (I995, I69), o Tratado estipulava diversas indenizações aos britânicos: o Art. $3^{\circ}$ determinava a transferência da ilha de Hong Kong para os britânicos “à perpetuidade". As forças militares chinesas mostraram-se despreparadas para enfrentar o armamento das potências europeias e dos EUA. O Império do Meio não conseguiu manter a defesa do país e a integridade do seu território ${ }^{\mathrm{I}}$. Pode-se afirmar que a presença europeia dentro do território chinês contribuiu fortemente para a derrocada da dinastia Qing, a última de uma longa lista. A proclamação da República da China foi em I9II. A maior parte do século XIX foi de privações para os chineses: restrições para deslocar-se por todas as áreas urbanas e limitações em prover a sua alimentação. Essas privações ajudam a explicar o número crescente de rebeliões ao longo do século XIX.

A China experimentou uma fase de dissenções internas nas décadas seguintes à proclamação da república. A divisão política doméstica entre nacionalistas e comunistas contribuiu para fragilizar a nação. A invasão japonesa na Manchúria em I93I constitui marca histórica que se somou às ocupações europeias do século anterior. A superação ocorreu depois da derrota do Japão na última guerra mundial, em particular a partir de $\mathrm{I}^{\mathrm{o}}$ de outubro de

Io Cash-and-carry pode ser traduzido por compra com pagamento à vista.

II Artigo publicado na Foreign Affairs de junho de 2015.

I2 A economia chinesa teria deixado, assim, de ser não-monetária, baseada em obrigações feudais e de trocas, por outra economia monetária com base no mercado.

I3 Havia processos industriais rudimentares domésticos para a tecelagem do algodão e beneficiamento de chá e de seda.

I4 Episódios históricos precedentes são a invasão, mongol com a implantação da dinastia Yuan, e a implantação da dinastia Qing, originária da Manchúria, região que, até I644, não fazia parte da China. 
I949, com a inauguração da República Popular, quando os chineses experimentaram uma nova etapa política e social. Reafirmou-se, na ocasião, a determinação das lideranças de restaurar o antigo orgulho. Mas as históricas preocupações com as invasões estrangeiras mostraram-se mais uma vez presentes com a Guerra da Coréia e, no final da década de iو60, com o contencioso fronteiriço sino-russo. Na produção agrícola, a iniciativa de Mao Tsé-tung do Grande Salto para a Frente, em I958, desarticulou a economia agrícola chinesa. A consequência foi a falta generalizada de alimentos. $O$ número contabilizado de mortes por fome entre I959 e I961 varia. Gipouloux $(2005,64)$ replica quantitativos de fontes diferentes que vão de 16,5 milhões de pessoas a 30 milhões.

Portanto, desenvolver estratégia referente à produção e distribuição de alimentos para um contingente historicamente elevado como o chinês sempre se constituiu em preocupação dos governantes. Eventual desarticulação do sistema agrícola seja por efeitos naturais ou decorrentes de medidas equivocadas geraram fome; logo, constrangimentos sociais.

\section{O Desafio da Segurança Alimentar}

A partir de I978, com a chegada do grupo liderado por Deng Xiaoping, o extraordinário crescimento do PIB chinês per capita ${ }^{15}$ permitiu que a população obtivesse crescente poder aquisitivo ao longo das décadas seguintes. Verifica-se, a partir daquela data até hoje, que o aumento do poder aquisitivo tem sido heterogêneo em dois níveis: litoral-interior; e campo-cidade. A população urbana do litoral tem obtido maiores rendas. As quatro modernizações implantadas por Deng Xiaoping - agricultura, C\&T, defesa e indústria - foram iniciadas em sítios escolhidos no litoral. Isto é, o processo de modernização da RPC girou no entorno das chamadas zonas econômicas especiais (ZEE) próximas do mar. Apesar de vigorar o hukou ${ }^{16}$, a migração doméstica tornou-se crescente. Nos dois níveis citados acima, dois conjuntos de oposições apareceram no seio da sociedade chinesa: locais (hukou permanente) x estranhos (hukou temporário); e camponês (hukou agrícola) x citadino (hukou não agrí-

I5 O crescimento do PIB per capita entre I978 e 2005 teria sido de 8,5\% (Naughton, I40), 8,7 (Yasheng 2008, 254); entre 2008 e 2013, 8,3, de acordo com a OECD, capítulo 5, 2015. Lau (2015) informa crescimento de 8,6\% entre i978 e 2014 .

I6 Segundo Gipouloux (op. cit., II8), trata-se de um registro de residências. Quando foi implantado esse sistema na época de Mao Tsé-tung, a pessoa obtinha alimentos e trabalho somente onde estivesse registrada. Ao longo do tempo, observa-se menor eficiência no seu controle, a ponto de legiões de migrantes deixarem o campo, atraídos por melhores condições de trabalho nas cidades. 
cola). Essas distinções contribuem para aprofundar o desnível qualitativo de renda. O antigo flat equality buscado por Mao foi de todo abandonado. Mas, de um modo geral, há crescente poder aquisitivo da população chinesa, tanto a urbana quanto a rural ${ }^{17}$. Yang, em matéria publicada no diário China Daily de 22/4/20I5, informa que a renda da população rural chinesa alcançou, em 20I4, I0489 Yuan (US\$ I693) e da população urbana, 2938I Yuan (4743 US\$).

Reconheça-se, contudo, que a modernização da agricultura obteve bom sucesso. A iniciativa de Deng Xiaoping em retornar a histórica unidade produtiva do campo para a familiar - revogando a implantação da produção agrícola com fulcro em comunas - revelou-se exitosa. A simples possibilidade de as unidades familiares poderem comercializar nos mercados das aldeias e vilas o excedente entregue ao Estado aumentou a produção agrícola chinesa. Para ilustrar esta afirmação, Gipouloux $(2007,70)$ mostra que a produção cerealífera chinesa cresceu de 304,77 milhões de ton. em I978 para 469,47 milhões de ton. em 2004. A produção chinesa de cereais em 2014 foi estimada em 492,8 toneladas métricas (ton ${ }^{3}$ ), segundo o Departamento de Agricultura dos EUA. ${ }^{18}$

Observa-se, portanto, um processo acelerado de urbanização do povo chinês ${ }^{19}$. Deve-se alertar, contudo, que não é correto atribuir-se o processo de urbanização somente à migração campo-cidade; ele é consequente, em especial, de redefinições do perímetro urbano determinadas pelo crescimento populacional na RPC. A derivada primeira desse processo é a redução das franjas de terras agricultáveis dos entornos urbanos, a reduzir a área produtora de alimentos. Ou seja, há a concorrência de três fatores confluentes a pressionar a produção doméstica de alimentos na RPC: o crescimento populacional; a redução de áreas plantadas; e o aumento do poder aquisitivo das

I7 De acordo com Gipouloux (op. cit. 216) e com Naughton (op. cit. 210), entre I978 e 2004, o aumento da renda média das famílias rurais foi de 587,2\%, e das famílias urbanas, de 553,9\%, preços em referência a 2004 .

I8 O Departamento de Agricultura dos EUA (USDA em inglês) equivale ao Ministério da Agricultura brasileiro. O documento que informa o valor da produção chinesa de cereais anota também as produções de outros: EUA, 439,3 ton.; Índia, 238,7 ton.; Rússia, Ioo, I ton.; Brasil, 99,I ton.; outros, 744,2 ton. Portanto, por esses quantitativos, o Brasil é o quinto maior produtor de cereais no mundo. A Organização para a Cooperação Econômica e Desenvolvimento (OECD em inglês) e a Organização para a Alimentação e Agricultura (FAO em inglês), no seu Highlights 2013-2022 previu 478,8 ton. para a RPC.

I9 Pode ser visualizada graficamente essa informação no sítio da Organização das Nações Unidas, na pagina da Divisão de População do Departamento de Assuntos Econômicos e Sociais. Por meio dele, visualiza-se a interseção das curvas das populações rural e urbana no ano de 20I5, quando a população nas cidades passa a suplantar a rural; muda-se, a partir daí, o paradigma demográfico histórico chinês. 
pessoas, que passam a diversificar a dieta ${ }^{20}$. Reforça-se, assim, o argumento de que as pressões sobre os governantes para ofertar de alimentos seguem fio condutor histórico, com a magnitude do contingente populacional, em 20I4, de I.367.820.000, segundo o Escritório Nacional de Estatística da RPC.

\section{O Desafio da Segurança Energética}

A modernização da indústria constituiu corolário virtuoso à implantação das zonas econômicas especiais. A absorção de tecnologias novas e processos produtivos advindos do exterior transformaram a RPC na "fábrica do mundo". Com efeito, os chineses desenvolveram o setor secundário da sua economia nos últimos 37 anos com eficiência incomum. Os produtos industrializados chineses são encontrados nos mais diferentes mercados. E a sua qualidade está a conquistar consumidores. Os manufaturados chineses já competem com os de outras origens não somente pelos preços comercializados, mas pela confiabilidade e durabilidade. Foi um aprendizado desenvolvido a partir das modernizações, já citadas, redigidas por Deng Xiaoping e por Zhou Enlai e anunciadas por este no IV Congresso Nacional do Povo em janeiro de 1975 (Bergère, Bianco and Domes I990, p. 8I; Mazzetti 2000, 8I; Marti 2007, 28I; Gao 20II, 32I) e praticadas no governo de Deng Xiaoping a partir de 1978.

Contudo, a matriz energética da década de 70 do século XX, calcada no uso intensivo do carvão, mostrou-se crescentemente incapaz de sustentar o desenvolvimento industrial do país. A flexibilidade do emprego de derivados de petróleo frente ao carvão passou a exigir maior produção doméstica de óleo. É certo que o carvão ainda é a fonte mais usada para térmicas geradoras de eletricidade e para aquecimento no inverno nos imóveis do interior, de acordo com a Administração da Informação sobre Energia do governo norte-americano ${ }^{21}$. Mas o parque industrial cada vez mais sofisticado consome derivados de petróleo. Acresça-se o incremento dos modais de transporte que também consomem esses derivados. Atualmente, as curvas de procura e de produção doméstica afastam-se cada vez mais ${ }^{22}$. Segundo essa fonte, em 2014 , a produção chinesa de petróleo foi de 4,23 milhões de bl/d, para um consumo

20 O sítio da Organização para a Economia e Cooperação e Desenvolvimento (OECD), e Organização para Alimentos e Agricultura das Nações Unidas mostra gráficos que ilustram claramente a procura por diversificação do consumo de alimentos, contemplando maior percentual de proteínas de origem animal.

2I US Energy Information Administration em inglês. A análise apresentada pelo relatório, de maio de 2015 , aponta que $65 \%$ da energia consumida na RPC tem origem no carvão.

22 Idem 
de $10,7 \mathrm{bl} / \mathrm{d}$. Referente à produção de gás liquefeito de petróleo, em 2013, foi de 4, I trilhões de metros cúbicos (tmc.) frente ao consumo de 5,7 tmc.

A solução buscada pelo governo da RPC tem sido a importação de petróleo e gás. Três regiões são fornecedoras à RPC: Oriente Médio e Ásia Central (inclui Rússia); África; e América do Sul. Os dirigentes chineses diversificaram, pois, as fontes de fornecimento nessas três regiões. Em 20I4, os maiores fornecedores de petróleo, em percentuais, foram: Arábia Saudita (16\%), Angola (13\%), Rússia (ı1\%), Omã (ı०\%), Irã e Iraque (9\%), Emirados Árabes Unidos e Venezuela (4\%), Colômbia e Kuwait (3\%), e Brasil, Congo, Sudão do Sul e Cazaquistão (2\%); outros fornecedores completam os IO\% restantes ${ }^{23}$. Uma conclusão parcial emerge dessa busca chinesa por combustíveis fósseis no exterior: existe potencial vulnerabilidade frente a eventual instabilidade política em alguma região produtora; e há complexidade de prover segurança das linhas de fornecimento de variadas extensões.

Os principais modais de transporte de petróleo e gás importados pela RPC são dutovias e hidrovias marítimas. As dutovias conectam os países produtores da Ásia Central e da Rússia à RPC. A maioria dos países a fornecer óleo e gás para ela faz parte da Organização para a Cooperação de Xangai (OCX). Esta organização reúne o Cazaquistão, o Quirguistão, a RPC, a Rússia, o Tadjiquistão e o Uzbequistão. Os dutos de óleo e gás estendidos da Ásia Central e da Rússia são ligados aos existentes no interior da RPC. A Organização reforça os laços políticos e comerciais dos países membros. Trata-se de um instrumento fundamental a contribuir para a segurança energética da RPC, pois enseja a manutenção da estabilidade política na região. Afinal, os Estados que acompanham a RPC na Organização fizeram parte da antiga União das Repúblicas Socialistas Soviéticas (URSS); ainda há especial ligação daqueles países localizados na Ásia Central com a Rússia. Por meio da OCX a RPC tem, ainda, condições de projetar a sua influência sobre a Ásia Central.

As hidrovias marítimas - ou linhas de comunicação marítimas (LCM) - apresentam duas vulnerabilidades para a RPC: extensão; e pontos de estrangulamento, ou choke points. São eles: Estreito de Bab el Mandeb que liga o Mar Vermelho ao Golfo de Aden; o Estreito de Ormuz, entre o Golfo Pérsico e o Mar da Arábia; e o Estreito de Málaca que conecta o Oceano Índico ao Mar do Sul da China. Segundo o Departamento de Defesa dos EUA, utilizando-se do Relatório Anual para o Congresso, referente ao desenvolvimento militar e de segurança da RPC, ano de $2014,82 \%$ de todo o petróleo e $30 \%$ de todo o gás que transita do Oceano Índico para o Mar do Sul da China (MSCh) passam por Málaca. Uma interrupção nesse estreito obrigaria os navios a transpo-

23 US Energy Information Administration. 
rem uma das duas passagens mais ao sul na Indonésia, Lombok ou Sunda, com acréscimo de aproximadamente três dias de viagem. Se essas passagens também forem bloqueadas, os navios teriam que contornar a Austrália, com aumento médio de quinze dias em trânsito. Acarretaria aumento de custos no transporte da carga e do seu seguro.

Uma iniciativa chinesa para mitigar a vulnerabilidade no Estreito de Málaca foi a parceria firmada com Mianmar: um conjunto de dutos transporta óleo e gás do litoral deste último até a província chinesa de Yunan. Dessa forma, os navios chineses transferem a carga para as instalações no litoral de Mianmar sem necessitarem transitar pelo Estreito. Por meio de dutos domésticos, a RPC distribui os produtos brutos ou já beneficiados em refinarias das províncias para todo o território. Outra iniciativa chinesa está no acordo com o Paquistão: a RPC adequa o porto de Gwadar para receber a carga de petróleo e gás dos navios e, em seguida, transportá-los por dutovia para a RPC. Seriam, mais uma vez, evitadas as passagens indonésias, facilmente bloqueadas por forças militares adversárias ou por acidentes à navegação ocorridos ali.

A RPC utiliza também as LCM para importar minério de ferro, fundamental para a sua indústria. A produção doméstica chegou a I,32 bilhões de ton. em 2013, enquanto a australiana alcançou no mesmo ano 530 milhões de ton., e a brasileira, 386,27 milhões, naquele ano segundo sumário do Departamento Nacional de Produção Mineral brasileiro, elaborado pelo técnico Carlos de Jesus. Contudo, de acordo com este, o Brasil pode ser considerado o segundo maior produtor se for considerado o teor médio do minério de ferro, isto é, a quantidade de minério obtida em uma tonelada de material extraído. Consoante esse critério, a produção chinesa real seria de 390 milhões de ton. Explica-se, assim, a voracidade chinesa por importar minério de ferro, em especial da Austrália e do Brasil.

\section{Forças de Defesa Chinesas}

Para garantir o fornecimento de óleo e gás importados, a RPC vem desenvolvendo a sua indústria de defesa. Na medida em que as necessidades domésticas de insumos de energia aumentam, as importações crescem. O Relatório para o Congresso norte-americano citado acima analisa o Exército Popular de Libertação (EPL) da RPC nas suas vertentes naval, terrestre e aérea. Com orçamento oficial de US\$ I36,3 bilhões ${ }^{24}$, o EPL procura dotar-se de

\footnotetext{
24 Vale observar que o quantitativo orçamentário oficial é suplementado por receitas advindas de atividades não militares, como, por exemplo, empreendimentos em hotéis e em operadoras de telefonia pertencentes às forças militares.
} 
meios para contribuir para a segurança energética chinesa. Afinal, nos dias de hoje, as históricas preocupações chinesas com as invasões dos bárbaros do entorno transformaram-se na inquietação permanente com a disponibilidade de insumos de energia para o seu parque industrial e o transporte. Trata-se, pois, de a RPC precaver-se de eventuais restrições das suas importações de óleo e gás.

Há que se notar, contudo, a distinção entre a operacionalização da segurança das linhas de fornecimento terrestres originárias da Ásia Central e a das LCM. As dutovias correm por territórios pertencentes à quase totalidade dos membros da OCX. Neste caso, pode-se afirmar que a segurança é alcançada por intermédio dessa Organização; as responsabilidades assumidas pelos seus membros ensejam a inferência de que segurança chinesa no fornecimento de óleo e gás repousa nesse ambiente institucional. Uma conclusão parcial é a de que o transporte de energia por meio das dutovias não requer permanente pronto emprego de força militar. O ambiente institucional proporcionado pela OCX aponta, em princípio, para a utilização de instrumentos não militares chineses, caso haja eventuais problemas na Ásia Central.

No caso das LCM, as características e a magnitude da proteção implicam na contribuição do EPL. Os Estados que costeiam o MSCh têm diferentes posturas em face da Convenção das Nações Unidas para o Direito do Mar (CNUDM) $)^{25}$, conhecida também como Convenção da Jamaica, de ıo de dezembro de $1982^{26}$. A Convenção é um regime internacional importante, mas as iniciativas de alguns dos Estados da região mostram que o ambiente no MSCh é de instabilidade. Pelas LCM daquele mar transitam navios que demandam a portos dos diferentes países do sudeste asiático e do Extremo Oriente. Respeitante à RPC, $85 \%$ de todo o petróleo importado e $33 \%$ de todo o gás passam pelas suas LCM, de acordo com o mencionado Relatório Anual para o Congresso norte-americano, de 20I4. E há jazidas petrolíferas comprovadas, em especial nas imediações dos arquipélagos Paracel e Spratly.

Embora a RPC tenha ratificado a Convenção em 7 de junho de 1996 (Austin I998, 54 et seq.), Pequim tem insistido que a RPC tem soberania ${ }^{27}$ sobre quase todo o MSCh. A soberania reclamada baseia-se na História. Segundo Austin, o levantamento cartográfico realizado por ocasião das viagens do

25 Em inglês: United Nations Conventions on the Law of the Sea (UNCLOS).

26 A CNUDM entrou em vigor em I6 de novembro de I994, como está no Art. I ${ }^{\circ}$ do Decreto Presidencial $n^{\circ}$ I530 de 22 de junho de i995. Este Decreto informa também que o Brasil ratificou a convenção em 22 de dezembro de ig88.

27 O termo soberania empregado neste artigo é o do tipo vestfaliano, conceito apresentado por Krasner $(1999$, 9) para significar que as decisões das autoridades domésticas não aceitam influência de atores externos sobre área submetida somente às leis nacionais. 
almirante chinês Zheng He, no século I5, seria argumento para fundamentar tal reclamação. A investigação de Pinotti $(2015,43)$ sugere que a demanda chinesa por soberania no MSCh teria origem anterior, na dinastia chinesa Xia, que governou entre 2100 a.C. e I600 a.C. Pinotti também verifica que o Vietnã avoca a História para defender soberania sobre as Paracel e as Spratly. Observe-se que o Vietnã também ratificou a CNUDM, em 25 de julho de I994, de acordo com a Divisão de Assuntos Oceânicos e da Lei do Mar da ONU ${ }^{28}$.

Outros Estados costeiros ao MSCh também rivalizam com a RPC com respeito àquele Mar. As reivindicações baseadas na História desafiam a observação da CNUDM. E as soberanias reivindicadas por esses são causa de contenciosos que geram frequentes fricções com a RPC. Mas a Convenção sugere caminhos pacíficos para solucionar disputas, especialmente nos artigos 287 e 298. A RPC declarou, em 25 de agosto de 2006 que mantem a sua interpretação sobre a soberania referente às ilhas dos arquipélagos Paracel e Spratly, como está no documento da Divisão de Assuntos Oceânicos citado acima. De fato, a CNUDM sugere que disputas respeitantes a sobreposição de áreas marítimas devem ser resolvidas, de início, bilateralmente; se não houver acordo, devem ser consultadas instâncias independentes que constam do Art. 287 da Convenção. Portanto, a CNUDM orienta as partes para solucionarem as suas disputas por meio pacífico. Mas fricções têm sido notadas. Somente 2014 a RPC gerou tensões com as Filipinas por causa da presença de nacionais de ambas nas Spratley, em especial nos baixios chamados Second Thomas. Com a Malásia o contencioso está por conta dos baixios Reed Bank, nas proximidades de Bornéu. E com o Vietnã, no mesmo ano, o Relatório do Departamento de Defesa dos EUA ao Congresso, em 20I5, conta nove eventos de tensão nas Paracel.

Além dos Estados costeiros ao MSCh, a RPC experimenta desconforto com os EUA. O Congresso dos EUA não ratificou a CNUDM. Além disso, os norte-americanos mantem acordos militares com Estados da região, como a República da Coréia e o Japão. São dois outros importadores de petróleo que utilizam quase exclusivamente as LCM do MSCh para o transporte. A presença de navios e aeronaves da Marinha norte-americana nas suas águas tem gerado tensões na região. O Relatório citado no parágrafo anterior menciona um caça da MEPL que interceptou uma aeronave de patrulha marítima da Marinha dos EUA, colocando ambas em condições de risco.

Outro Estado que se apresenta no MSCh é a Rússia. A Marinha russa utiliza as LCM daquele mar para que os seus navios possam transitar entre as bases de Sebastopol, na Criméia, e de Vladivostoc, no extremo leste do país. O

28 Em inglês: Division for Ocean Affairs and the Law of the Sea. 
ministro de defesa adjunto da Rússia anunciou, em Singapura, a 30 de maio deste ano, que a sua marinha participará de exercícios navais no MSCh em $20 \mathrm{6}$ com a marinha de Brunei. Declaradamente, ele ressaltou que a presença da marinha russa naquelas águas serve para marcar presença, mostrar bandeira e, assim, contrabalançar a presença da marinha dos EUA. O ministro afirmou também que os norte-americanos adotam políticas contrárias às da Rússia e às da $\mathrm{RPC}^{29}$. A presença russa no MSCh não pode ser vista como uma ameaça. A RPC é importadora de tecnologia militar russa. A Marinha do EPL (MEPL) e a Força Aérea do EPL (FAEPL) têm aeronaves de fabricação russa nos seus inventários ${ }^{30}$ e Mizokami (20I5) noticia a aquisição dos novos submarinos da classe Yasen pela RPC à Rússia. Ou seja, a RPC depende, parcialmente, da aquisição de material de defesa russo.

O MSCh é, pois, importante para os países da região. As LCM vitais para eles, a perspectiva de exploração petrolífera e de gás, e a pesca, fonte de alimentação para as populações asiáticas realçam o interesse de todos pelas suas águas e ilhas ali existentes. A RPC alinha o EPL como instrumento para usar nessa área marítima se for necessário. E o braço naval, isto é, a MEPL é o mais indicado para operar naquele mar, apoiado pelas aeronaves quando se fizer necessário. Assim, a MEPL possui três esquadras, cujas bases são: a Esquadra do Norte em Qingdao, a mais próxima de Pequim; a do Leste, em Dinghai; e a do Sul, em Zhan Jiang, frente à ilha-província de Hainan. Os submarinos nucleares estão concentrados na Esquadra do Norte; as demais possuem submarinos convencionais. As Esquadras possuem também fragatas, contratorpedeiros, navios próprios para lançarem fuzileiros navais para terra, e navios patrulha dotados de mísseis. A MEPL tem ainda no seu inventário um porta-aviões. Ele tem operado até agora com o propósito de integrar satisfatoriamente o binômio navio-aeronave.

A parte terrestre do EPL tem as suas grandes unidades aquarteladas no leste e meio leste do país. Decorre este posicionamento da menor preocupação com ameaças originárias dos Estados vizinhos. No plano doméstico, a região leste concentra a maior riqueza econômica da RPC, tanto industrial quanto agrícola - as terras agricultáveis situam-se a leste e no sul - e a maior parte da população está nessa parte do território. O discurso recorrente tem por alvo a ilha de Taiwan, considerada por Pequim como província rebelde. Estremecimentos existem cada vez mais espaçadamente, provavelmente em decorrência do diálogo mais intenso de autoridades de ambos os lados do Estreito de Taiwan. O posicionamento das forças terrestres na parte oriental do

29 Notícia veiculada no sítio da Sputnicknews.

30 Há vasta literatura sobre o tema. Pode ser acessado o artigo de Felix Chang em página do Foreign Policy Research Institute. 
país reflete ainda antiga preocupação com eventual fortalecimento das forças de defesa japonesas.

A FAEPL, da mesma forma que a vertente terrestre, tem as suas bases localizadas no leste. As preocupações que orientam este posicionamento são os mesmos para força terrestre. As aeronaves da FAEPL sintonizam as suas operações com as da MEPL, cujas bases se situam nos arredores das esquadras. A FAEPL está preparada para apoiar operações navais sobre parte do MSCh e tem como adversário mais próximo a Força Aérea da República da China, isto é, Taiwan. A superioridade aérea local sobre o Estreito, ainda hoje, pertence à Força Aérea da ilha. Parte-se do pressuposto que eventual invasão de Taiwan só poderia partir do mar; logo, a dificuldade para os invasores repousaria nas ações aéreas da ilha. Há discreto apoio logístico norte-americano ás forças militares de Taiwan, de acordo com o Taiwan Relation Act, de abril de I979.

Pode-se afirmar que, das vertentes do EPL, a MEPL tem, de fato, a maior responsabilidade quanto ao provimento, por parte do governo, da segurança alimentar e da segurança energética. As LCM próximas percorrendo áreas disputadas, como as do MSCh, e as exteriores a esse mar cada vez mais extensas determinam que essa marinha tem que estar preparada para defender os interesses da RPC e as dimensões da segurança. Não é sem razão que se verifica um esforço mais intenso em dotar a MEPL de meios navais e aeronavais para a missão. O engajamento da MEPL na proteção das LCM que correm ao longo da costa oriental africana contra piratas, nas proximidades do chifre da África é uma forma de treinar as guarnições para executar tarefas mais complexas. A hipótese de ser instalada uma base naval chinesa em Djibuti pode ser indício de expansão do apoio distante. Visitas a países costeiros ao Atlântico Sul, com longas travessias e permanência no mar reforçam o argumento.

Ainda no campo da defesa, deve-se lembrar que o inventário nuclear terrestre é da responsabilidade da Segunda Força de Artilharia. Lá estão os mísseis convencionais de alcance de 200 quilômetros $(\mathrm{km})$ que protegem o território chinês até os que alcançam $3300 \mathrm{~km}$, a alcançarem todas as ilhas indonésias, grande parte da Índia, o Irã, a Rússia e o Estreito de Bering. Também constam os mísseis intercontinentais balísticos cujos alcances vão de I750 km até $13000 \mathrm{~km}$, estes cobrindo até a América do Sul. Evidentemente todo esse aparato nuclear tem esses alcances de projeto. São de fundamental importância os sistemas de controle desses mísseis, cuja confiabilidade não se conhece. Igualmente não se tem informações confiáveis sobre a autonomia de concepção, projeto e fabricação locais de todos os componentes. 


\section{O Projeto Estratégico de Xi Jinping}

Xi Jinping está ciente das dependências de importação de alimentos e de energia para atender a demanda interna na RPC. A sua interpretação do termo "segurança" aproxima-se do entendimento de Barry Buzan apud Mutimer (I999, 79). Buzan decompõe a segurança em cinco dimensões: militar; política; econômica; social; e ambiental. Pode-se comprovar esta afirmação ao lermos o discurso do presidente chinês na primeira reunião do Conselho de Segurança Nacional, em I5 de abril de 2014 (XI Jinping 20I4, 242). O título é sugestivo: "Persistir em uma visão holística sobre a segurança nacional e desenvolver a segurança nacional com características chinesas”. Ele afirma que

devemos persistir em uma visão holística sobre a segurança nacional, ter a segurança do povo, a segurança política e a segurança econômica como princípio, ponto essencial e base, respectivamente. Precisamos ainda tomar a segurança militar, cultural e social como garantia, apoiando-nos na promoção da segurança internacional e abrindo um caminho de segurança nacional com características chinesas.

E adiante Xi Jinping reforça os seus argumentos ao recomendar "estabelecer um sistema de segurança nacional que integre a segurança política, territorial, militar, econômica, cultural, social, científica e tecnológica, dos recursos e da energia nuclear". Do leque de dimensões de segurança visualizado por Xi Jinping, a econômica confere condições para que, por exemplo, a militar e a social possam ser obtidas. Ou seja, a garantia das importações de alimentos e de energia depende da segurança econômica. Mas, sem a segurança militar, mesmo dispondo da econômica, a RPC poderia experimentar constrangimentos em assegurar a satisfação da demanda interna complementada por importações, especialmente os produtos transportados por via marítima. Com efeito, as dimensões de segurança são interdependentes.

É razoável, portanto, o desenvolvimento do EPL, principalmente da sua Marinha. No sistema político Partido-Estado, a afirmação de $\mathrm{Xi}^{3 \mathrm{1}}$ é emblemática: "Devemos adotar como principal prioridade a educação ideológica e política para que a concepção de direção absoluta do Partido sobre as Forças Armadas se enraíze nas mentes dos oficiais e soldados”. E adiante assevera "É necessário fortalecer a construção partidária nas Forças Armadas, assegurando o comando do Partido sobre as tropas no sentido ideológico, político e organizacional". As decisões referentes às Forças Armadas são da alçada do Comitê Central do Partido e da Comissão Militar Central. A missão do EPL é

3I Xi Jinping op. cit. p. 262.

188 Austral: Revista Brasileira de Estratégia e Relações Internacionais v.4, n.7, Jan./Jun. 2015 
defender o país e o PCCh. Os discursos de Xi Jinping refletem exatamente a concepção do sistema político chinês.

A idealização da Rota da Seda foi apresentada por Xi Jinping ${ }^{32}$ no ano de 20I3. Em setembro, ele deu a conhecer o Cinturão Econômico da Rota da Seda, em discurso na Universidade Nazarbayev, Cazaquistão. Não deixa de enfatizar o reforço dos laços de confiança mútua proporcionado pela OCX. Esse Cinturão Econômico visa, portanto, contribuir para que os dutos que transportam óleo e gás para a RPC não sejam afetados. Ainda em 2013, no mês de outubro, Xi discursou no Congresso Nacional da Indonésia sugerindo a construção conjunta da Rota da Seda Marítima no Século XXI ${ }^{33}$. A referência institucional onde repousaria a construção seria a Associação das Nações do Sudeste Asiático (ASEAN, em inglês) ${ }^{34}$. Isto é, os instrumentos institucionais - OCX e ASEAN - ofereceriam legitimidade para a política multinacional chinesa; mas com vista a contribuir para a garantia da segurança alimentar e da segurança energética. Pode-se afirmar que a Rota Marítima não se limitará ao MSCh, mas se estenderá aos oceânicos Î́ndico e Atlântico.

Como fonte de financiamento de infraestrutura nas regiões de interesse, em sintonia com a Rota Marítima, foram criados o Banco de Investimento na Infraestrutura Asiática e o Novo Banco de Desenvolvimento dos BRICS35. O primeiro deles poderá ajudar a RPC a criar vínculo na configuração ASEAN +I. E auxiliará a atenuar os contenciosos no MSCh, onde há interesses ligados à exploração de petróleo, pesca e acompanhamento do trânsito marítimo. O Novo Banco dos BRICS fomentará a execução de projetos de infraestrutura úteis ao escoamento de matérias primas de interesse da RPC nos países africanos e íbero-americanos. E a MEPL está sendo fortalecida para contribuir para proteger as LCM de interesse da RPC, mesmo as mais extensas.

Pode-se afirmar, portanto, que as duas Rotas da Seda se constituem nos objetivos estratégicos da RPC; e a Grande Estratégia para a obtenção desses objetivos fundamenta-se positivamente: na OCX para a vasta área terrestre da Ásia Central; e na criação do Banco de Investimento na Infraestrutura Asiática e do Banco dos BRICS para favorecer o atendimento das necessidades chinesas transportadas pelo mar. O vigor do estabelecimento de acordos e a velocidade com que os investimentos chineses viabilizam as obras de infraestrutura parecem demonstrar a determinação de Pequim em manter a sa-

32 Idem, p.345.

33 Ibidem, p. 35I.

34 A ASEAN é uma zona de livre comércio, com vocação para mercado comum, que reúne Brunei, Camboja, Cingapura, Filipinas, Indonésia, Laos, Malásia, Mianmar Tailândia e Vietnã. 35 Acrônimo criado por Jim O’Neill, economista inglês do banco Goldman Sachs, para designar Brasil, Rússia, Índia, China e África do Sul. 
tisfação interna sem qualquer tergiversação. O PCCh certamente percebe nos tempos atuais os históricos desafios dos precedentes governantes do Império do Meio. E o presidente Xi Jinping sabe que a sua Grande Estratégia deve oferecer instrumentos para que os parceiros da RPC possam comungar com ela um diálogo fundamente cooperativo. Isto é vital para a RPC.

\section{As Relações Sino-Brasileiras}

O Brasil e a RPC estabeleceram relações diplomáticas em I5 de agosto de 1974 (Cervo e Bueno, 425). O conceito de diplomacia adotado pelo governo brasileiro era chamado "diplomacia responsável”. Tal conceito, segundo Oliveira (2005, I49), "passou a ser projetada como pragmática, ecumênica e responsável”, isto é, não intervenção em assuntos alheios, procurava acompanhar a realidade internacional como ele se apresentava, e depositava a responsabilidade na ética. O conceito orientou também a abertura de relações diplomáticas do nosso País com vários países recém- independentes, dentre os quais as antigas colônias portuguesas. Retomou-se, na ocasião, uma vocação manifestada no governo Jânio da Silva Quadros, quando o chanceler Francisco Clementino San Tiago Dantas gravou o conceito de política externa independente (PEI). Ambas as políticas têm nos dias de hoje a versão Sul-Sul.

Apesar de se estar em plena guerra fria, o alcance do estabelecimento das relações Brasil-RPC mostrou-se exitoso. Afinal, os dois Estados comungam princípios de política externa muito próximos. Cabral (20I0, I95) comenta que o Brasil defende os princípios da autodeterminação, igualdade e benefícios recíprocos entre Estados, independência, não intervenção, e soberania nacional. Do seu lado, a RPC enfatiza os "Cinco Princípios da Coexistência", isto é, coexistência pacífica, igualdade e benefícios recíprocos, não agressão, não intervenção em assuntos internos, e respeito à soberania e integridade. Há, portanto, condições objetivas para que os dois países possam aprofundar as suas relações porque usam uma linguagem diplomática orientada por princípios similares.

Ao longo do tempo, foram instituídos o Conselho Empresarial Brasil-China (2004); em 2006, a Comissão Sino-Brasileira de Alto nível de Concertação e Cooperação (COSBAN); o Diálogo Estratégico (2007); e em 2008 foram criados o Diálogo Financeiro Brasil-China e a Agenda China para a área comercial. Os desdobramentos vêm ocorrendo com velocidade crescente, à mercê dos interesses mútuos e das oportunidades nascentes. A criação do já citado Banco dos BRICS é um vetor de financiamento importante e poderá alavancar iniciativas em diferentes campos, como infraestrutura, C\&T 
e implantação de novas plantas industriais. Possivelmente contribuirá para dinamizar empreendimentos como a fábrica da Empresa Brasileira de Aeronáutica (EMBRAER) instalada na RPC, e desenvolver novas versões do China Brazil Earth Resources Sateillites (CBERS).

Mas é no campo comercial que se verifica maior assimetria entre os dois países. De acordo com o Ministério das Relações Exteriores, o Brasil foi o I7 $7^{\circ}$ destino das exportações chinesas entre janeiro e setembro de 20I4, com total de US\$ 37 bilhões e o sétimo na origem como origem das importações da RPC, com US\$ 40 bilhões no mesmo período. A assimetria não reside exatamente nos valores envolvidos ou no saldo/déficit realizado. A fonte de preocupação do governo brasileiro e da iniciativa privada nacional está na dissimetria qualitativa da pauta comercial. O nível tecnológico inerente aos produtos aponta para um agudo primarismo dos itens exportados pelo Brasil. A derivada é o encolhimento do setor industrial nacional em face da concorrência dos produtos chineses. Os quadros abaixo mostram essas relações no comércio dois países.

Principais produtos exportados para a RPC, em milhões de dólares norte-americanos, período janeiro-setembro de $20 \mathrm{O} 4$.

\begin{tabular}{|l|c|c|c|c|}
\hline Descrição & 2013 Valor & $\begin{array}{c}2013 \text { part. } \% \\
\text { no total }\end{array}$ & $\begin{array}{c}2014 \text { ljan./ } \\
\text { set.) valor }\end{array}$ & $\begin{array}{r}\text { 2014 part. \% } \\
\text { no total }\end{array}$ \\
\hline $\begin{array}{l}\text { Soja em grãos e } \\
\text { sementes }\end{array}$ & 17.148 & $37,3 \%$ & 16.616 & $40,9 \%$ \\
\hline Minérios & 16.394 & $35,6 \%$ & 12.709 & $31,3 \%$ \\
\hline Combustíveis & 4.035 & $8,85 \%$ & 3.474 & $8,6 \%$ \\
\hline Pastas de ma- & 1.582 & $3,4 \%$ & 1.711 & $4,2 \%$ \\
\hline deira & 1.433 & $3,1 \%$ & 880 & $2,2 \%$ \\
\hline Açúcar & 643 & 1,45 & 826 & $2,05 \%$ \\
\hline Peles & 597 & $1,3 \%$ & 530 & $1,3 \%$ \\
\hline Ferro e aço & 446 & $1,0 \%$ & 521 & $1,3 \%$ \\
\hline Carnes & 625 & $1,45 \%$ & 421 & $1,0 \%$ \\
\hline Gorduras e óleos & 454 & $1,05 \%$ & 334 & $0,8 \%$ \\
\hline Tabaco, & & & & \\
\hline sucedâneos & Fonte: MRE/DPR/DIC com base nos dados do MDIC/SECEX. & \\
\hline
\end{tabular}


Principais produtos importados da RPC, em milhões de dólares norte-americanos, período janeiro-setembro de 2014.

\begin{tabular}{|c|c|c|c|c|}
\hline Descrição & 2013 Valor & $\begin{array}{l}2013 \text { part. } \% \\
\text { no total }\end{array}$ & $\begin{array}{l}2014 \text { (jan./ } \\
\text { set.) valor }\end{array}$ & $\begin{array}{l}2014 \text { part. } \% \\
\text { no total }\end{array}$ \\
\hline $\begin{array}{l}\text { Máquinas } \\
\text { elétricas }\end{array}$ & 10.869 & $29,15 \%$ & 10.898 & $29 \%$ \\
\hline $\begin{array}{l}\text { Máquinas } \\
\text { mecânicas }\end{array}$ & 8.132 & $21,85 \%$ & 7.151 & $19,1 \%$ \\
\hline $\begin{array}{l}\text { Produtos químicos } \\
\text { orgânicos }\end{array}$ & 2.184 & $5,9 \%$ & 2.232 & $6,0 \%$ \\
\hline Ferro e aço & 978 & $2,6 \%$ & 1.388 & $3,7 \%$ \\
\hline Plásticos & 1.006 & $2,7 \%$ & 1.070 & $2,9 \%$ \\
\hline Automóveis & 1.034 & $2,8 \%$ & 1.002 & $2,7 \%$ \\
\hline $\begin{array}{l}\text { Obras de ferro e } \\
\text { aço }\end{array}$ & 1.017 & $2,75 \%$ & 978 & $2,6 \%$ \\
\hline $\begin{array}{l}\text { Vestuário exceto } \\
\text { de malha }\end{array}$ & 884 & $2,4 \%$ & 935 & $2,5 \%$ \\
\hline $\begin{array}{l}\text { Filamentos } \\
\text { sintéticos ou } \\
\text { artificiais }\end{array}$ & 745 & $2,05 \%$ & 809 & $2,2 \%$ \\
\hline $\begin{array}{l}\text { Instrumentos de } \\
\text { precisão }\end{array}$ & 789 & $2,15 \%$ & 780 & $2,1 \%$ \\
\hline
\end{tabular}

É correto afirmar que a modernização do campo brasileiro exigiu melhor capacitação da mão-de-obra e sofisticação tecnológica e melhor gestão no comércio dos produtos primários brasileiros. A mecanização da lavoura implicou, por outro lado, na redução quantitativa dos trabalhadores rurais. Mas os quadros mostrados demonstram que a pauta de importação brasileira de manufaturados compete e pressiona o nosso setor industrial. Trata-se de desafio posto há alguns anos para o binômio governo-iniciativa privada brasileiro. Os manufaturados chineses ocupam um amplo leque de produtos, desde simples eletrodomésticos até automóveis. A sofisticação da nossa produção agrícola e de lavra de minérios levada aos chineses representa dois terços da pauta exportadora; e o produto agrícola é, praticamente, um só. 


\section{Considerações Finais}

A existência de um setor industrial razoavelmente sofisticado no Brasil aponta para uma diferenciação nas relações entre a RPC comparativamente àquelas que os chineses exercitam com Estados africanos. O modelo angolano, que foi adotado por outros países daquele continente não é adequado para o nosso País. Não podemos regredir a um status quo ante, do século XIX e primeiras décadas do século passado, quando se dizia que o Brasil era um País de vocação agrícola. A infraestrutura foi instalada visando a exportação desses bens primários. A injeção de recursos chineses na realização de projetos que contemplem exportação de bens primários parece um retrocesso. Sabemos ser do interesse direto da RPC, em face das suas carências. O governo chinês tem demonstrado que tem objetivos nacionais estratégicos claros e persegue uma Grande Estratégia para atingir esses objetivos.

O desenvolvimento de iniciativas na infraestrutura brasileira tem que comungar interesses dos dois lados. Não é razoável que elas tenham por fim principal o transporte de commodities. O próprio exemplo chinês do passado, quando os produtos exportados não geraram progresso industrial deveria guardada a distância do tempo - alertar para o que ocorre hoje no Brasil. A RPC buscará o que necessita com lastro na cooperação. Logo, é interessante alargar o horizonte brasileiro a descortinar a diversificação da pauta na nossa relação com os chineses. Parece claro que exigirá esforço hercúleo para cobrimos o gap tecnológico, de modo a que reduzamos as assimetrias que observamos diante dos chineses. Dentro do ambiente cooperativo, teremos que ser criativos para equilibrarmos a qualidade das relações nas diferentes dimensões.

Ficou demonstrado que a RPC necessita ser cooperativa, em um ambiente internacional nem sempre estável. A busca chinesa por exercer soberania sobre áreas marítimas disputadas explica o cuidado do PCCh em desenvolver o EPL, em especial a MEPL. Com efeito, a busca por alimentos e energia está mais complexa, porque distante. No ambiente do Atlântico Sul, é crível inferir a futura presença de navios da MEPL. Há exercício cooperativo da RPC com Estados africanos e sul-americanos. Mas é necessário reconhecer que há algumas diferenças de leitura entre a RPC e os EUA, como se observa no MSCh. O desenvolvimento de eventual instabilidade no Atlântico Sul não é útil para a RPC nem para o Brasil. Dada a proximidade de princípios norteadores das políticas externas de ambos, dentro da relação Sul-Sul, é útil que nos antecipemos, de modo a evitar contenciosos na região. É uma tarefa a ser executada pela diplomacia. 


\section{REFERÊNCIAS}

Alvin, Cheng-Hin Lim. 20I5. "Latin America China's 'New Normal' - Analysis". Eurasia Review. Acessed May 28, 20I5.http://www. eurasiareview.com/280520I5-latin-america-and-chinas-new-normalanalysis/.

Austin, Greg. 1998. China's Ocean Frontier: International law, military force and national development. Camberra: Allen \& Unwin.

Babones, Salvatore. 2015. "Trade and Trouble: What China can learn from I640 economic bust". Foreign Affairs. Accessed June 7, 2015. http:// www.foreignaffairs.com/articles/china/2015-06-07/trade-and-trouble.

Bergère, Marie-Claire, Lucien Bianco, and Jürgen Domes. I990. "La Révolution culturelle et les crises de succession (i966-1976)". In: La Chine au XXe Siècle: de 1949 à aujourd'hui, 6I-87. Paris: Fayard.

Brautigam, Deborah. 2009. The Dragon's Gift: the real story of China in Africa. New York: Oxford University Press.

Cabral, Severino. 20ıo. "As Relações Brasil-China e os Desafios do Século XXI". In O Século da China, by Argemiro Procópio (ed.), I85-202. Curitiba: Juruá.

Cervo, Amado Luiz, e Clodoaldo Bueno. 2002. "Meios e resultados do pragmatismo em política externa (I967-I979)". In História da Política Exterior do Brasil. 2. ed., 397-425. Brasília: UnB.

Chang, Felix K. 2012. "China's Naval Rise and the South China Sea: An operational assessment". Foreign Policy Research Institute. Accessed June 08, 20I5. http://www.fpri.org/print/246.

Cheng, Anne. 2008. “A Aposta de Confúcio no Homem”. In História do Pensamento Chinês, 63-99. Petrópolis: Vozes.

Confúcio. 1997. Analetos. São Paulo: Pensamento.

Diegues, Antonio Carlos Sant'Ana. 2002. "Bacia Amazônica”. In Povos e Águas: inventário de áreas úmidas. 2. ed., 7I-I94. São Paulo: Núcleo de Apoio à Pesquisa sobre Populações Humanas e Áreas Úmidas Brasileiras, USP.

Division for Ocenan Affairs and the Law of the Sea. United Nations. Declarations or Statements upon UNCLOS ratification. Accessed June 2, 20I5. http://www.un.org/depts/los/convention_declarations.html.

Fairbank, John King, and Merle Goldman. 2006. “A Primeira Unificação: o confucionismo imperial”. In China: uma nova história, 6o-8I. Porto Alegre: L\&PM. 
Foschete, Mozart. 200I. Relações Econômicas Internacionais. São Paulo: Aduaneiras.

Gao, Wenqian. 20II. “A Batalha Final”. In Zhou Enlai: o último revolucionário perfeito. 3I7-378. Rio de Janeiro: Record.

Gipouloux, François. 2007. "A Longa Marcha do Campesinato Chinês”. In A China do Século XXI: uma nova superpotência?, 6I-Ioo Lisboa: Instituto Piaget.

Howlett-Martin, Patrick. 2009-20I0. "Chine-Brésil, une aliance fragile". Monde Chinois 20 Hiver: 85-88.

Instituto Brasileiro de Geografia e Estatística. China. Accessed January ıo, 2015. http://www.ibge.gov.br/paisesat/main_frameset.php.

Jesus, Carlos Antônio Gonçalves de Ferro. 20I4. Departamento Nacional de Pesquisa Mineral. Sumário 20I4. Accessed April I4, 20I5. http://www. dnpm.gov.br/dnpm/sumarios/ferro-sumario-mineral-20I4.

Krasner, Stephen D. I999. Sovereignty. Princeton: Princeton University Press. Lau, Lawrence J. et al. 2015. The Economic Relationship between the Mainland and Hong Kong. Hong Kong: Chinese University of Hong Kong; Stanford University. Accessed March I2, 20I5. http://www.igef.cuhk/ igef_media/people/lawrencelau/presentations/english.

Martin, Michael E. 2007. "Notas, Reforma e Abertura". In A China de Deng Xiaoping: o homem que pôs a China na cena do século XXI, 28I-3Io. Rio de Janeiro: Nova Fronteira.

Mazzetti, Fernando. 2000. "O fim da dinastia". In De Mao a Deng, 79-89. Brasília: UnB.

Mizokami, Kyle. 20I5. "National Interest: China precisa cada vez mais das armas russas.”. Sputnik News. Accessed May 3I, 20I5. http:// br.sputniksnews.com/defesa/20I5053I/II7I454.html.

Moura, José Augusto Abreu de. 20I4. "A Defesa do Brasil”. In A Estratégia Naval Brasileira no Pós-Guerra-Fria, 87-I59. Rio de Janeiro: FEMAR.

Mutimer, David. I999. "Beyond Strategy: critical thinking and the new security studies". In Contemporary Security and Strategy, by Craig A. Snyder (Ed.), 77-97.. New York: Routledge.

National Bureau of Statistics of China. 20I4. Statistical Comuniqué of the People's Republic of China on the 2014 National Economic and Social Development. Stats. Accessed March 30, 20I5. http://www.stats.gov. cn/english/PressRelease/201502/t20150228_687439.html.

Naughton, Barry. 2007. “The Chinese Economy Before I949”. In The Chinese Economy: transitions and growth, 33-54. Cambridge: MTI Press. 
Oliveira, Henrique Altemani. 2005. "A Política Externa nos Governos Militares”. In Política Externa Brasileira, 107-167. São Paulo: Saraiva.

Organization for Economic Cooperation and Development and Food and Agriculture Organization. 2015. Agricultural Outlook 2013-2025 Highlights. Accessed April, Io, 2015. http:/www.oecd.org/berlin/ OECD-FAO\%2oHighlights_FINAL_with_Covers\%2o(3).pdf.

Pinotti, Talita de Mello. 20I5. "As Relações entre China e Vietnã no Mar do Sul da China: perspectiva asiática de análise.”. Master's Thesis. Instituto de Filosofia e Ciências Humanas, Universidade Federal do Rio Grande do Sul, Porto Alegre, Brazil.

Principal parceiro comercial desde 2009, China amplia investimentos no Brasil. Portal Planalto. Noticia a assinatura do Plano de Ação Conjunta 2015-202I. Accessed May 20, 2015. http://www2.planalto.gov. br/2015/05/principal-parceiro-comercial-desde-2009-china-ampliainvestimentos-no-brasil.

Rússia participará de exercícios navais no Mar do Sul da China. Sputnik News. Accessed May 3I, 20I5. http://br.sputniknews.com/ mundo/20150530/1168265.html.

Spence, Jonathan D. I995. "O Primeiro Choque com o ocidente”. In Em Busca da China Moderna: quatro séculos de história, I55-I74. São Paulo: Companhia das Letras.

Swain, Michael D.; and Ashley J. Tellis. 2000. "Summary". In Interpretating China's Grand Strategy: past, present, and future, ix-xiv. Washington: Rand.

Thorstensen, Vera. 200ı. Organização Mundial do Comércio. 2. ed. São Paulo: Aduaneiras.

United Nations Organization. United Nations Conventions on the Law of the Sea. Accessed February Io, 20I5. http://www.un.org/depts/los/ convention_agreements/texts/unclos/unclos_e.pdf.

. Organization for Economic Co-operation and Development (OECD) and the Food Agricultural Organization (FAO). Highlights 20I3-2022. Accessed May IO, 20I4. http://www.oecd.org/berlin/OECD-FAO\%2O Highlights_FINAL_with_covers\%20(3).pdf.

. China. Accessed April ıo, 2015. http://www.oecd.org/china/goingfor-growth-china-2015.pdf.

United States Department of Agriculture. World Agricultural Production. Circular Series WAP 7-I5, July 2015. Accessed July IO, 2015. http:// apps.fas.usda.gov/psdonline/circulars/production.pdf. 
United States Department of Defense. Annual Report to Congress: military and security developments involving the People's Republic of China 2015. Accessed May I6, 2015. http://www.defense.gov/pubs/20I5_China_ Military_Power_Report.pdf.

United States Energy Information Administration. China. Accessed July Io, 20I5. http://www.eia.gov/beta/international/analysis_includes/ countries_long/China/china.pdf

Visentini, Paulo Fagundes et. al. 2013. A África e as Potências Emergentes: nova partilha ou cooperação sul-sul? A presença da China, do Brasil e da Índia. Porto Alegre: Leitura XXI.

Xi, Jinping. 20I4. A Governança da China. Trad. China Radio International. Pequim: Editora de Línguas Estrangeiras Co. Ltd.

Yang, Wangli. 2015. "Rural-urban income gap narrows". China Daily, Accessed April 22, 2015. http://www.chinedaily.com.cn/2015-04/22/ content_20509439.htm.

Yasheng, Huang. 2008. "Capitalism with Chinese Characteristics". In Capitalism with Chinese Characteristics: entrepreneurship and the State, 233-298. New York: Cambridge.

\section{RESUMO}

Este artigo versa sobre os desafios fundamentais percebidos pela República Popular da China (RPC): segurança alimentar e segurança energética. Eles são evidenciados pela demanda superior à produção doméstica. Esta relação obriga o Partido Comunista Chinês a estabelecer acordos com outros países para que possa equilibrar a oferta frente à procura. Os instrumentos utilizados pela República Popular da China para garantir o cumprimento dos acordos são institucionais e militares. Estes últimos são necessários para o exercício da soberania chinesa no Mar do Sul da China e para manter livres as linhas de comunicação marítimas. Em consequência, são examinadas as relações sino-brasileiras, em especial as mais recentes.

\section{PALAVRAS-CHAVE}

República Popular da China; Segurança Alimentar; Segurança Energética.

Recebido em 7 de agosto de 2015. Aprovado em 3 de setembro de 2015. 


\section{DESENVOLVIMENTO E A OMC: LIBERDADE PARA QUEM?}

\section{Rafael Rosa Cedro ${ }^{1}$}

\section{Introdução}

Este artigo explora três abordagens analíticas distintas que oferecem propostas para a reflexão sobre a questão do comércio internacional, proporcionando uma visão crítica do funcionamento da Organização Mundial do Comércio (OMC) e da sua suposta defesa do livre comércio como motor do desenvolvimento. Tais abordagens são: vantagens comparativas; teoria da dependência e análises das Cadeias Globais de Commodities (CGC) / Cadeias Globais de Valor (CGV) (que serão consideradas em conjunto para os fins deste artigo). Inicialmente, é fornecida uma breve visão geral enfatizando quais são as suposições centrais dessas perspectivas em termos de como o sistema de comércio internacional funciona. Em seguida, o artigo refere-se a excertos de materiais importantes da OMC - alguns preparados pelo Secretariado da OMC e textos legais de acordos da OMC - para mostrar que essa Organização apresenta a perspectiva das vantagens comparativas como se fosse um princípio central guiador do seu funcionamento. Além disso, o artigo baseia-se na história da OMC e nos elementos da sua operação real para avaliar a extensão em que essas três abordagens analíticas distintas relacionadas ao comércio internacional, exploradas aqui, estão presentes no âmbito da OMC e/ou ajudam a explicar seu funcionamento. $\mathrm{O}$ artigo conclui evidenciando que a posição que a OMC adota em favor de estimular os países a dependerem fortemente de suas vantagens comparativas no seu compromisso dentro do mundo do livre comércio, citando aqui as palavras de Ha-Joon Chang, é na verdade não

\footnotetext{
I PhD em Estudos de Desenvolvimento do Instituto Internacional de Estudos Sociais (ISS), em Haia, na Holanda. Especialista em Políticas Públicas e Assuntos Governamentais, na área econômica, Ministério do Planejamento. Tem sido um dos negociadores do governo brasileiro na Rodada Doha da OMC, na Organização das Nações Unidas, e em outros acordos de integração econômica. É autor do livro Desenvolvimento Rural e a OMC: A Experiência do Brasil (Rural Development and the WTO: The Experience of Brazil). E-mail: rafael_cedro@yahoo.com.br
} 
mais do que uma tentativa velada de "chutar a escada" através da qual os atuais países desenvolvidos têm subido ao longo de suas trajetórias históricas (e da qual, em grande parte, eles ainda fazem uso hoje em dia).

\section{O Funcionamento do Comércio Internacional e Desenvolvi- mento pelos Prismas das Vantagens Comparativas, Teoria da Dependência e Análises das CGC/ CGV}

O tópico "comércio" - compreendendo considerações subjacentes de como a divisão internacional do trabalho deveria ser definida - e sua relação com o desenvolvimento econômico têm sido, há tempos, uma questão que chama a atenção de economistas políticos e analistas de relações internacionais. Esta primeira seção proporciona uma visão geral sobre a forma como os padrões de comércio internacional e sua relação com o desenvolvimento são concebidos do ponto de vista das vantagens comparativas, teoria da dependência e análises das Cadeias Globais de Commodities (CGC) / Cadeias Globais de Valor (CGV).

É importante reconhecer que essas três perspectivas analíticas devem compreender outros elementos que não são restritos apenas ao comércio. Ou seja, suas teorizações e quadros analíticos fornecem ideias e trazem suposições que também se relacionam a aspectos como evolução tecnológica, padrões de produção, padrões de consumo e outros. Dado o escopo deste artigo, esta seção foca nos aspectos mais imediatos relacionados ao comércio decorrentes dessas abordagens analíticas, concentrando-se nos aspectos fundamentais que são necessários para a análise realizada no artigo.

\subsection{Vantagens Comparativas}

Inicialmente sistematizada como uma teoria pelo economista clássico David Ricardo (I8I7), sua ideia central sobre o comércio internacional parte de uma suposição teoricamente baseada de que este beneficia todos os países. De acordo com essa perspectiva, isso aconteceria até mesmo para os países que não apresentam nenhuma vantagem absoluta em setores da sua economia se comparados a outros países. A lógica por trás dessa teoria é bastante simples. Um exemplo dessa perspectiva pode ser visto a seguir:

Vantagem comparativa significa que os custos de oportunidade para produzir certo bem são expressos no custo de produção para outro bem: no Canadá quatro unidades de cerveja podem corresponder à produção de 
uma unidade de vinho, enquanto no México a relação pode ser dois para um. Isso não significa que é mais barato produzir cerveja no México. Uma vantagem comparativa pode vir junto de uma desvantagem absoluta. Se seguirmos essa teoria, espera-se que o Canadá concentre-se na produção de cerveja e o México na de vinho, até mesmo quando os custos absolutos para ambos os produtos forem mais baixos no Canadá (Henning 2007).

A partir de tal perspectiva, portanto, a progressiva especialização de países em desenvolvimento em produzir principalmente apenas poucas commodities (ou matérias-primas) de pouco valor agregado não era tida como um problema. Ao contrário, isso permitiria um funcionamento mais eficiente da economia internacional e do sistema de comércio como um todo, promovendo crescimento e desenvolvimento para todos. Amsden $(2007, \mathrm{I} 2)$ aponta que, defendendo tal perspectiva, uma vez um economista ortodoxo sintetizou tal ideia em uma frase simbólica: "um país pode ganhar tanto produzindo batata frita quanto produzindo chips de computadores".

\subsection{Teoria da Dependência}

Em uma crítica direta à abordagem das vantagens comparativas, a teoria da dependência enfatiza um conjunto de elementos que desencoraja os países em desenvolvimento a adotarem ingenuamente o discurso do livre comércio internacional como motor de desenvolvimento. Por exemplo, de acordo com Amsden (2007, I2), como argumentado por Raul Prebisch, "os preços de matéria-prima, que representam cerca de noventa por cento das exportações do Terceiro Mundo, têm caído ao longo do tempo em relação aos preços das manufaturas". Assim, "os exportadores de matérias-primas têm que exportar cada vez mais para apenas se manterem". Além disso, "eles também perdiam nas mudanças tecnológicas”. Conforme destacado por autores como Cardoso (I977) e outros, as características padrão do comércio internacional muitas vezes destacadas por diferentes estudiosos da teoria da dependência incluem: relações persistentes de "colonização" e um padrão de comércio marcado pelo domínio dos países desenvolvidos e suas empresas ${ }^{3}$ de uma forma que prejudicou as perspectivas dos países em desenvolvimento de atingirem sua própria industrialização e desenvolvimento. Assim, a apropriação da riqueza, a menos que algo de diferente fosse feito, tenderia a ser desigual, privilegiando fortemente as economias centrais (desenvolvidas), em

\footnotetext{
2 Existentes ainda após os processos formais de independência/descolonização.

3 Não raramente, sob a proteção das tradicionais elites locais, que se beneficiam de um processo interno desigual.
} 
detrimento das periféricas ("subdesenvolvidas"4).

Uma solução proposta, decorrente desta perspectiva, frequentemente envolveria a adoção, pelos países em desenvolvimento, de um desenvolvimento mais autônomo e de estratégias de comércio mais pró-ativas e menos subalternas aos interesses das nações desenvolvidas. A estratégia de Industrialização por Substituição de Importações (ISI) foi frequentemente destacada como um possível caminho para colocar a proposta anterior em prática.$^{5} \mathrm{Em}$ tal contexto, o conceito de proteção da "indústria nascente" ${ }^{6}$ teria um papel importante. Instrumentos de política tais como "tarifa temporária de proteção à competição internacional", "subsídios", "imitação dos produtos manufaturados estrangeiros e aprendizado com eles para desenvolver novas tecnologias, até o ponto em que o país e suas indústrias estejam aptos para competir com produtos de maior valor agregado tanto no comércio interno quanto no internacional" eram elementos, entre outros (como o investimento governamental em áreas estratégicas), que deveriam ser considerados e combinados de forma apropriada. Em outras, palavras, "políticas de desenvolvimento" eram concebidas como um elemento central na promoção efetiva da prosperidade dos países, considerando o cenário global vigente.

Não obstante, isso não é o mesmo que dizer que a teoria da dependência é contra comércio per se. Ao contrário, a teoria da dependência destaca a necessidade de refletir sobre a previsibilidade e a existência atual de padrões de comércio (e de produção). A partir disso, a teoria da dependência muitas vezes defende a importância de os Estados dos países em desenvolvimento agirem estratégica e proativamente em favor das mudanças de tais padrões por meios que seriam considerados mais tendenciosos a promover o desenvolvimento doméstico e a romper progressivamente com as relações de subordinação e subdesenvolvimento.?

4 Ver, por exemplo, Frank (I966) e Furtado (1964).

5 Para mais sobre estratégias de ISI ver Bauman e Franco (2006) e Tavares (I977).

6 Conceito originalmente explorado por List (1885).

7 A este respeito, por exemplo, é importante notar que, mesmo na visão de Prebisch, a substituição de importações não foi vista como incompatível com o comércio. Em algumas circunstâncias, ele defenderia, países em processo de industrialização podem precisar exportar matérias-primas e commodities (durante o período de industrialização) a fim de serem capazes de importar máquinas e equipamentos necessários. Outro aspecto da estratégia relacionada com o comércio associado à abordagem da teoria da dependência é a promoção do comércio entre os países com níveis menos discrepantes de desenvolvimento econômico e tecnológico. Por exemplo: ver as proposições para melhorar o comércio regional na América Latina, como impulsionado pela Comissão Econômica das Nações Unidas para a América Latina e o Caribe (CEPAL) e, também, de forma mais geral, entre os países do Sul global, no âmbito da Conferência das Nações Unidas sobre o Comércio e Desenvolvimento (UNCTAD) - ambas as orga- 


\subsection{Análises de Cadeias Globais de Commodities (CGC) / Cadeias Globais de Valor (CGV)}

As análises de CGC e CGV são originadas como derivações analíticas dos estudos do Sistema Mundo, que compreendia um ramo do pensamento de alguma forma influenciado pela teoria da dependência. Dentro de tal perspectiva inicial, a avaliação do funcionamento das cadeias de commodities funcionou como ferramenta analítica relevante na observação de desequilíbrios e outros traços da distribuição da produção, excedente e receitas geradas, etc, ao longo das diferentes etapas de processamento de uma commodity, desde sua forma natural bruta até sua forma final para consumo. A teoria do Sistema Mundo, entretanto, não perderia de vista analisar uma cadeia de commodities como sendo parte de um contexto global mais amplo, em que as cadeias de diversas commodities funcionariam simultaneamente, moldando uma dinâmica econômica global inter-relacionada (Hopkins e Wallerstein I986; Talbot 2004). A partir dessa perspectiva, é importante ter em mente que, uma vez que tais trajetórias de cadeias de commodities frequentemente ocorrem através das fronteiras nacionais, o quadro internacional que regulamenta o comércio, então, influencia as perspectivas de tais atividades transnacionais (assim como ele também acaba sendo influenciado por elas, através de pressões exercidas por poderosos grupos econômico-políticos ou atores e, muitas vezes, por Estados nacionais).

Com o passar do tempo, entretanto, o quadro analítico da cadeia de commodities, que originalmente tinha uma abordagem muito mais de "economia política", foi gradualmente apropriado por analistas e pesquisadores orientados para os negócios. Em tal medida, o quadro foi progressivamente riscado dos seus conteúdos mais estruturais-políticos. Rótulos como as análises das Cadeias Globais de Commodities (CGC) e Cadeias Globais de Valor (CGV) foram atribuídos a tais modalidades mais recentes. Ainda assim, a despeito de uma preocupação muito menos avaliativa sobre como o funcionamento das cadeias de commodities pode afetar o desenvolvimento ou subdesenvolvimento das nações em um sentido mais amplo, como destacado em trabalhos como Gerefi e Korzeniewicz (I994), tais análises incluem, normalmente, a avaliação de elementos em dimensões, tais como: estrutura de insumo-produto (ou seja, um conjunto de produtos e serviços ligados em uma sequência de atividades econômicas de valor agregado); territorialidade (análise da estrutura particular da produção distribuída geograficamente e/ou entre empresas de diferentes tamanhos); estrutura de governança (por exemplo, autoridade e relações de poder que influenciam na forma como recursos

nizações que tinham sido encabeçadas por Prebisch. 
financeiros, materiais e humanos são alocados e fluem dentro de uma cadeia) e contexto institucional.

As recomendações, no entanto, nos quadros mais recentes das análises de CGC/ CGV, normalmente tenderiam a focar mais no desenvolvimento ("atualização") de uma perspectiva de empresa, sob a tentativa de crescer com uma maior apropriação e controle do processo (e valor) dentro da cadeia de commodities, em vez de abordar questões mais amplas e fundamentais do contexto do desenvolvimento das nações ou global, em um sentido mais abrangente.

\section{Avaliando a Presença e/ou Utilidade das Perspectivas de Comércio Analisadas no Presente Artigo em Relação ao Âmbito da OMC}

Esta seção proporciona uma breve análise do quadro político da OMC em um diálogo com as perspectivas vistas na primeira seção, bem como elementos do discurso, história e funcionamento da Organização.

\subsection{A Supremacia das "Vantagens Comparativas" como uma Perspectiva Oficialmente Definida como Diretriz}

Em vez de reconhecer que existem (ou deveriam existir) diferentes perspectivas analíticas - com diferentes conclusões - sobre os padrões de comércio internacional, liberalização do comércio e sua capacidade de promover (ou dificultar) o desenvolvimento econômico, no seu discurso formal, a OMC reconhece explicitamente apenas a existência da perspectiva das "vantagens comparativas". De fato, o documento "Understanding the WTO", feito pelo Secretariado da OMC como uma explicação geral e completa sobre a Organização, qualifica tal perspectiva como sendo o "senso comum" econômico (ver: WTO 2007, 13). Em uma seção de tal documento - "The case for open trade" - o Secretariado da OMC, utilizando um discurso monoeconômico ${ }^{8}$, destaca:

8 Devemos observar na passagem a seguir que ela se refere à "economia" como sendo um corpo teórico singular e não a uma perspectiva que nasce de uma entre diferentes escolas de pensamento existentes. Como Fairclough (2000) colocou em destaque, uma característica de importância do discurso neoliberal - a partir do qual a OMC consideravelmente se baseia - é a tentativa de promover a estruturação da diferença. Ou seja, ele faz uso de manobras retóricas de forma a esconder que poderia haver alternativas. 
A economia nos diz que podemos nos beneficiar quando estes bens e serviços são negociados. Basicamente, o princípio da "vantagem comparativa" diz que os países prosperam primeiramente ao tirar vantagem dos seus ativos para se concentrar no que eles podem produzir melhor, e então ao negociar esses produtos por produtos que outros países produzem melhor.

Em outras palavras, políticas liberais de comércio - políticas que permitem o fluxo irrestrito de bens e serviços - estimulam a competição, motivam a inovação e geram o sucesso. Elas multiplicam as recompensas que resultam da produção de melhores produtos, com o melhor design, pelo melhor preço. (WTO 2007,I4).

\section{(Ênfase dada pelo autor)}

A fim de não deixar dúvidas que a exploração das "vantagens comparativas" é a base do funcionamento pretendido do quadro político da OMC, o mencionado documento ainda apresenta uma caixa, referindo-se a David Ricardo, que explica as bases da sua teoria e cita as "vantagens comparativas" como sendo "sem dúvida a visão mais poderosa na economia" (WTO 2007, I4).

Não raramente, tal visão também é encontrada nas partes introdutórias de textos legais de acordos da OMC. Por exemplo, no texto oficial da Declaração de Marrakesh - acordo resultante da conclusão de negociações multilaterais da Rodada Uruguai, que instituiu a OMC - pode-se ver:

(...) o estabelecimento da Organização Mundial do Comércio (OMC) inaugura uma nova era da cooperação econômica global, refletindo o amplo desejo de operar em um sistema de comércio multilateral mais justo e aberto para o benefício e bem-estar dos povos. Ministros expressam sua determinação em resistir às pressões protecionistas de todos os tipos. Eles acreditam que a liberalização do comércio e regras fortalecidas atingidas na Rodada Uruguai irão levar a um ambiente mundial de comércio progressivamente mais aberto. Os ministros comprometem-se, com efeito imediato e até a entrada em vigor do acordo da OMC, a não tomar nenhuma medida comercial que possa enfraquecer ou afetar adversamente os resultados das negociações da Rodada Uruguai ou suas implementações. (WTO I994).

\section{(Ênfase dada pelo autor)}

Entretanto, apesar do discurso em defesa de tal livre comércio e das vantagens comparativas, como argumentado em Cedro e Vieira (20I0), Cedro (2008) e Cedro (20II), tal retórica, que é encontrada nos documentos expla- 
natórios da OMC e nas partes introdutórias dos acordos, não corresponde precisamente à realidade do funcionamento da Organização. Refiro-me aqui aos resultados concretos derivados da implementação do quadro político/regulatório da OMC. As subseções a seguir tentarão lançar alguma luz sobre isso, ao fornecer uma breve ligação com as outras perspectivas comerciais vistas na primeira seção.

\subsection{Verificando a Realidade: a Falácia das "Vantagens Comparativas" como a Base do Quadro Político da OMC}

\subsubsection{Aspectos Históricos}

Apesar de ser relativamente jovem como organização, a OMC carrega consigo uma história de "evolução" institucional do sistema mundial de comércio de pelo menos seis décadas. Ainda na esteira da Segunda Guerra Mundial, durante as discussões de Bretton Woods, uma Organização Internacional do Comércio (OIC) já havia sido prevista como uma terceira via do tripé econômico internacional para lidar com questões econômicas. O Fundo Monetário Internacional (FMI) primeiramente lidaria com as questões relativas à moeda e à balança de pagamentos, o Banco Internacional para Reconstrução e Desenvolvimento (BIRD, hoje parte do Grupo do Banco Mundial) foi criado para se concentrar na mobilização de recursos para a reconstrução pós-guerra e investimentos ao desenvolvimento, e a OIC seria responsável por fornecer uma estrutura para aumentar o comércio mundial. Ela tinha, contudo, como inicialmente havia sido negociada - com intensa participação de países em desenvolvimento - uma preocupação central não no próprio livre mercado. Em vez disso, o estabelecimento das preferências comerciais entre os participantes seria uma das muitas ferramentas que foram sendo concebidas para possibilitar o funcionamento de um sistema mundial de comércio que planejaria a promoção do desenvolvimento como seu objetivo primordial.

Neste contexto, princípios tais como indústria nascente e mecanismos e ferramentas associados estavam sendo discutidos para fazer parte do novo quadro de comércio global que estava em negociação. Contudo, depois de extensas negociações, tal quadro foi sumariamente rejeitado pelo governo dos Estados Unidos da América. Como podemos encontrar em trabalhos de autores como Hudec (I975) e Gardner (I969), os seguintes aspectos podem ser listados como as principais razões subjacentes para tal rejeição: (i) o conjunto de mecanismos de desenvolvimento previstos para ser parte do acordo foi considerado uma concessão excessiva em favor dos países em desenvolvi- 
mento e (ii) o novo quadro, que tentou reduzir o já existente desequilíbrio (em termos de uso do poder político e econômico) no comércio mundial, afetaria a capacidade das super potências de implementar políticas domésticas que impactassem negativamente outros países (por exemplo, os grandes subsídios à sua agricultura doméstica ${ }^{9}$ ).

Portanto, no lugar de uma OIC mais orientada para o desenvolvimento- que não teve sucesso pelo fato de que a maior potência econômica do mundo no momento não faria parte dela -, apenas o Acordo Geral de Comércio e Tarifas (GATT) foi instituído. Longe de ser uma organização completa, o GATT foi simplesmente um acordo de preferências comerciais. Como o historiador econômico Paulo Roberto de Almeida (2004, II6-7) descreve, o GATT é composto por elementos de, no máximo, um dos capítulos que teriam dado forma ao quadro da OIC. Entretanto, forneceu um quadro para negociações de rodadas subsequentes da liberalização do comércio, com regras e progressões a serem negociadas em etapas.

Inicialmente implementado por 23 partes contratantes, o GATT e seu sistema evoluíram durante as décadas seguintes, incluindo, progressivamente, novos participantes e novos passos no sentido do aprofundamento de um quadro para a liberalização do comércio (Trebilcock e Howse 2005, 23).

Pelas décadas subsequentes, houve momentos em que os países em desenvolvimento reclamaram e lutaram por mais espaço na estrutura econômica internacional para eles implementarem políticas na busca de seu próprio desenvolvimento; por exemplo, com o movimento da Nova Ordem Econômica Internacional (NOEI), que ganhou impulso na década de $1970^{\text {Io }}$.

9 O que não só permite que os produtores nos Estados Unidos combatam (em seu mercado interno) a competição decorrente dos países mais eficientes - em uma perspectiva das "vantagens comparativas" - mas também lhes permite assumir uma parte substancial do comércio mundial com seus produtos, exportando a preços subsidiados, como uma cena recorrente que pode ser observada em momentos posteriores e ainda hoje.

Io Já na sua introdução, I974 "Declaration on the Establishment of a New International Economic Order" deu o tom da luta afirmando a: "determinação de trabalhar com urgência para o estabelecimento de uma Nova Ordem Econômica Internacional baseada na equidade, igualdade soberana, interdependência, interesse comum e cooperação entre todos os Estados, independentemente dos seus sistemas econômicos e sociais que devem corrigir as desigualdades e reparar injustiças existentes, fazer possível eliminar a grande diferença entre os países desenvolvidos e os em desenvolvimento e garantir constantemente o aceleramento do desenvolvimento social e econômico e paz e justiça para as presentes e futuras gerações e para esse fim, declara: I. A maior e mais significante realização durante as últimas décadas tem sido a independência da dominação colonial e estrangeira de um grande número de povos e nações que lhes tem permitido tornarem-se membros da comunidade dos povos livres. Progresso tecnológico também tem sido realizado em todas as esferas das atividades econômicas nas ultimas três décadas, fornecendo assim um potencial sólido para melhorar o bem estar de todas as nações. Entretanto, os vestígios permanentes da dominação 
Baseado substantivamente em uma perspectiva influenciada pela teoria da dependência, o movimento NOEI exigiu, entre outras coisas, "espaço político" eficaz para os países em desenvolvimento no âmbito do sistema mundial de comércio, de forma a permitir uma redução dos desequilíbrios que foram percebidos em sua operação. Dentro de tal contexto, a Conferência das Nações Unidas sobre o Comércio e Desenvolvimento (UNCTAD) foi estabelecida como uma arena mais orientada para o desenvolvimento, em uma tentativa de conter a liberalização da agenda do GATT, que foi apontada como trabalhando em favor dos países já desenvolvidos, desfavorecendo os em desenvolvimento.

No entanto, após a queda do Muro de Berlim e a proclamação ideológica e coercitiva ${ }^{\text {II }}$ da "incontestável vitória do liberalismo econômico e político" (ênfase dada pelo autor) sobre todos os outros caminhos que possivelmente poderiam ter sido seguidos (Fukuyama I989, 3), o sistema GATT reapresentou sua supremacia em termos de poder. Ele destruiu muitas das demandas relacionadas ao "direito ao desenvolvimento" decorrentes do Sul que ganharam impulso com iniciativas como NOEI e o cenário da UNCTAD (Almeida 2004, II6-7), e estabeleceu um conjunto de regras mais compreensivas e estritas que engessou a habilidade dos países em desenvolvimento de romper com a sua posição subalterna no comércio internacional.

\subsubsection{O Sistema de Comércio Definido pela OMC}

A Rodada Uruguai de negociações multilaterais sobre sistema internacional de comércio (I986-94) foi, então, concluída. Foi nessa ocasião, como

colonial e estrangeira, ocupação externa, discriminação racial, apartheid e neo-colonialismo em todas as suas formas continuam estando entre os grandes obstáculos à plena emancipação e progresso dos países em desenvolvimento e todas as nações envolvidas. Os benefícios do progresso tecnológico não são compartilhados igualmente por todos os membros da comunidade internacional. Os países em desenvolvimento, que constituem setenta por cento da população mundial, representam apenas trinta por cento da renda mundial. Revelou-se impossível alcançar um desenvolvimento regular e equilibrado da comunidade internacional sob a ordem econômica internacional vigente. A diferença entre os países desenvolvidos e em desenvolvimento continua a ampliar em um sistema que foi estabelecido em um tempo em que a maioria dos países em desenvolvimento ainda nem existiam como Estados independentes e que perpetua a desigualdade." (Ênfase dada pelo autor) (United Nations General Assembly i974)

II É importante notar que, apesar da doutrinação ideológica, foi um período em que muitos países em desenvolvimento estavam encarando vulnerabilidades econômicas. Assim, eles precisavam do apoio das instituições financeiras internacionais, as quais, em grande medida, seguiram as diretrizes estabelecidas pelos países desenvolvidos. Por isso, entre as condições associadas ao apoio concedido, frequentemente havia pressão para que os países se comprometessem e aceitassem uma rodada ainda mais profunda e desequilibrada dentro do fórum do GATT. 
parte do acordo de "compromisso único" (pacote fechado) - que incluiu muitos elementos, que vão desde um sistema de aplicação quase judicial mais rigoroso a regras sobre proteção da propriedade intelectual ${ }^{12}$, liberalização do setor de serviços ${ }^{13}$ e outros -, que a OMC (uma organização internacional completa, não apenas um tratado) foi instituída (Pauwelyn 2005, 24-5; WTO I994). Sua missão: “Brevemente, (...) garantir que os fluxos comerciais sejam os mais fáceis, previsíveis e livres possíveis” (WTO 2009).

Deste modo, a questão é: livre para quem? Quando olhamos atentamente, observamos que o resultado real, como visto no cenário posterior ao estabelecimento da OMC e ao conjunto de regras que veio junto, está longe do que é ilustrado no discurso de justificativa. Em suma, podemos avaliar criticamente a OMC olhando para os seguintes elementos. Por um lado, os países em desenvolvimento foram pressionados a fazer esforços relevantes em abrir seus mercados e abdicar (e definir compromissos jurídicos sobre isso) de usar instrumentos que não apenas foram usados no passado pelos países desenvolvidos ${ }^{14}$, mas que ainda estão em uso nos dias de hoje (Chang 2002 e 2008). Por outro, o discurso de uma suposta já existente abertura dos mercados dos países desenvolvidos - que frequentemente sustentam suas alegações para os países em desenvolvimento a embarcar na perspectiva das vantagens comparativas no mundo do comércio - esconde uma falácia dupla.

O primeiro elemento de tal falácia é que o discurso mainstream frequentemente negligencia reconhecer que a dita abertura (relativamente baixas tarifas médias de importação) dos mercados de bens industriais dos países desenvolvidos ocorre em um cenário em que:

(a) Esses países já estão, frequentemente, muito à frente nos aspectos tecnológicos e com muitas das suas companhias bem estabelecidas como líderes de mercado (portanto, é mais fácil lidar com baixas tarifas de importação sobre seus competidores estrangeiros). É importar ressaltar, embora, que tal liderança, não raramente, foi atingida ao longo do tempo, quando aqueles mesmos países, como Chang (2002)

I2 Por meio do "Agreement on Trade-Related Aspects of Intellectual Property Rights" (TRIPS) I3 Como estabelecido pelo "General Agreement on Trade in Services" (GATS).

I4 Para uma crítica profunda sobre a história da globalização, ver o trabalho "Bad Samaritans: The Myth of Free Trade and the Secret History of Capitalism” (Chang 2008). Como apontado por Cerisier (20I2): "Os primeiros capítulos de Maus Samaritanos analisam a história "oficial" da globalização, como narrada pelos economistas do livre comércio e pela maioria das instituições internacionais (...) Dr Chang rejeita esse conto de fadas e argumenta que existem várias grandes falhas - e mentiras - na história oficial da globalização”. Chang faz isso usando vários casos exemplares e exaustivamente pesquisados. 
destaca, explicitamente fizeram uso da indústria nascente e das estratégias de desenvolvimento que eles agora rotulam como "ruins".

(b) Não apenas isso, mas a sua situação atual da "abertura comercial" é vinculada a um elemento complementar que consolida ainda mais sua liderança, em termos legais, perpetuando artificialmente a competitividade (em comparação com uma concorrência de livre mercado). Refiro-me aqui ao progressivo delineamento e aplicação das regras de propriedade intelectual (especialmente patentes industriais), no âmbito internacional..$^{\text {I5 }}$

O segundo elemento importante a ser considerado é que, ao mesmo tempo, o quadro político da OMC que foi estabelecido deixou, em grande parte, ainda como grandes exceções no quadro regulador do sistema de comércio mundial, importantes áreas que, naquele momento, eram - e ainda são - sensíveis às nações desenvolvidas. Por exemplo, agrícola e têxtil; ambos setores nos quais os países em desenvolvimento apresentariam, em muitos casos, a tendência de ser mais competitivos que os países desenvolvidos, se esses mercados fossem realmente abertos (excetuando-se os picos de tarifas altas e a enorme quantidade de subsídios que são mantidos pelo Norte ano após ano, como na agricultura, por exemplo). No entanto, não foi assim que aconteceu.

De fato, o que vimos foi que precisamente nas áreas em que os países do Norte eram mais sensíveis, ao invés de aplicar as mesmas regras para o aprofundamento do "livre comércio", acordos específicos (i.e. excepcionais) foram estabelecidos em textos à parte do corpo principal do GATT - então, o GATT I994, após a conclusão da Rodada Uruguai, que incorporou o original GATT I947 com as emendas subsequentes e forneceu o quadro geral para liberalização para o comércio mundial de bens. Por exemplo, o "Agreement on Agriculture" e o "Agreement on Textiles and Clothing" da OMC permitiram que os países desenvolvidos expandissem ao longo do tempo suas possibilidades de implementar o tipo de políticas de "distorção de mercado" que eles julgam como "políticas ruins" quando implementadas em outras áreas pelos países em desenvolvimento (Chang 2002; Chang 2008, 7; Cedro e Vieira 2010).

Apenas para mencionar dois exemplos relevantes, no setor agrícola, olhando para o cenário após a plena implementação dos compromissos esta-

I5 Por exemplo, ver o Acordo TRIPS da OMC, definido como o Anexo IC do Acordo de Marrakesh Estabelecendo a Organização Mundial do Comércio (WTO's TRIPS Agreement, set as the Annex IC of the Marrakesh Agreement Establishing the World Trade Organization), assinado em Marrakesh, Marrocos, em I5 de Abril de I994. 
belecidos pela Rodada Uruguai: (i) sobre o montante de subsídios internos de distorção do comércio autorizado pelo quadro da OMC aos Estados Unidos requererem anualmente, em comparação ao que é permitido ao Brasil para o mesmo tipo de subsídios; e (ii) com destaque para os extremamente altos picos tarifários de importação que as Comunidades Europeias são autorizadas a manter até mesmo depois de todos os compromissos estabelecidos pela Rodada Uruguai serem integralmente aplicados.

No primeiro caso, como apontado por Cedro e Vieira (2010, 132-4), o que observamos é que, para os "subsídios de caixa amarela" - aqueles considerados pela OMC como os que mais distorcem o mercado, e que, pela própria descrição da OMC, em sua maioria tendem a exercer efeitos negativos sobre outros países do globo quando aplicados -, a Organização autoriza os Estados Unidos a gastar até vinte vezes (2.094 por cento) o montante autorizado ao Brasil em termos da mesma categoria de subsídios (que, na verdade, se referem às políticas públicas), respectivamente US\$ I9.I bilhões versus US\$ 9I2 milhões por ano, em valores absolutos. Comparando com o tamanho das suas respectivas populações diretamente envolvidas em atividades agrícolas, isso significa uma autorização média de US\$3.350 por pessoa (EUA), contra US\$ 35 por pessoa (Brasil) por $\mathrm{ano}^{\mathrm{I} 6}$. Assim, isso figura como um resultado completamente desequilibrado, em favor do poder econômico do Norte, precisamente na área que é sensível em relação a deixar o mercado operar livremente (sem a intervenção estatal).

No segundo caso, o gráfico abaixo ilustra o que é comumente conhecido entre negociadores da OMC em Genebra como sendo um fato histórico: a persistência de picos tarifários extremamente elevados impostos pela União Europeia em muitos dos mais importantes produtos agrícolas em que os países em desenvolvimento são geralmente mais competitivos (Araujo et al 2005). Devemos observar, pelo gráfico, que não é raro encontrar produtos aos quais as Comunidades Europeias aplicam tarifas de importação de mais de I०० por cento do valor do produto importado, em alguns casos chegando a mais de 200 por cento (tornando o mercado daqueles blocos sobre aqueles produtos substancialmente inacessível para muitos países em desenvolvimento). Podemos destacar, por exemplo, produtos como: carnes, laticínios, alho, banana, azeite de oliva, açúcar, cogumelos, vegetais preparados, amido.

I6 Populações agrícolas respectivas de 5,7 milhões (EUA) e 25,8 milhões (Brasil), de acordo com dados da FAO, como apresentado por Cedro e Vieira (2010, I32). 


\section{Gráfico 1 - Estrutura das Tarifas de Importação da Agricultura das Comunidades Europeias: distribuição seguindo a classificação do Sistema Harmonizado internacional (SH)}

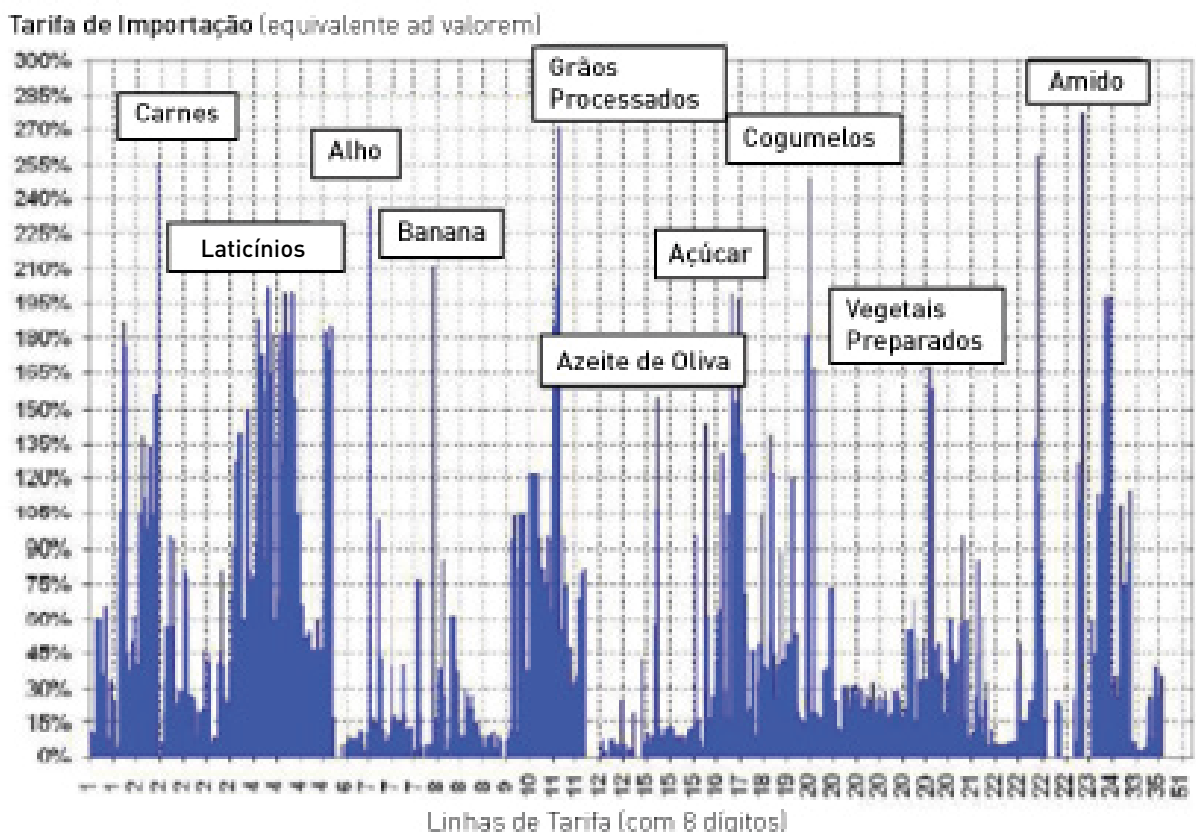

Fonte: Taric 2003 (em Araujo et al 2005)

Tudo isso e mais ${ }^{17}$ ocorre em um contexto em que o quadro da OMC é defendido como tendo fornecido um movimento em direção à realização de um suposto objetivo de permitir um "sistema de comércio multilateral mais justo e aberto" (ênfase dada pelo autor) ${ }^{18}$. Terminamos essa seção, então, retomando o alerta de Foucault (2004) sobre os discursos totalitários que retra-

I7 Para saber mais sobre o desequilíbrio dos compromissos estabelecidos dentro da OMC e o sistema de comércio internacional, bem como sobre os diferentes tipos de restrições impostas por tais estruturas, impedindo nações em desenvolvimento de perseguir estratégias de desenvolvimento e de comércio mais adequadas, ver os trabalhos "Putting Development First: The Importance of Policy Space in the WTO and IFIs" e "The Clash of Globalizations: Essays on the Political Economy of Trade and Development Policy", editados por Kevin Gallagher (Gallagher 2005 e 20I3). O primeiro trabalho engloba um conjunto robusto de ensaios de estudiosos críticos contemporâneos nas áreas de Economia Política Internacional e do comércio e desenvolvimento, incluindo Robert Wade, Alice Amsden, Ha-Joon Chang, e outros. O último é uma série de ensaios de Gallagher sobre diversos aspectos do mesmo tema desenhando sobre casos práticos e dialogando com a literatura contemporânea.

I8 Declaração de Marrakesh, do trecho previamente referido neste texto. 
tam uma perspectiva, existente entre outras, como se fosse única e universal: geralmente, tais discursos são usados a fim de disfarçar e perpetuar existentes relações de dominação e exploração.

\subsubsection{Análises Decorrentes da "Teoria da Dependência" e das "CGC/CGV"}

Como podemos ver aqui, a teoria da dependência nos fornece ideias interessantes para entender o real funcionamento da OMC. O quadro político da Organização - quando observamos os elementos discutidos no presente texto - parece não apenas seguir um caminho da Realpolitik em termos de abordagem para o sistema internacional de comércio, mas também tentar consolidá-lo, obrigando legalmente países em desenvolvimento a aceitarem uma divisão internacional do trabalho desequilibrada, na qual os países em desenvolvimento são relegados a permanecerem em um papel, em muitos casos, de provedores de matérias-primas para as companhias dos países do Norte (e, além disso, limitados àquelas commodities que não competem diretamente com as que o Norte também tem interesse em produzir). Como Frank (1996, I8) argumentaria, as condições do "subdesenvolvimento" de atuais países em desenvolvimento não representam um estado de "subdesenvolvimento" (como em um caminho linear, e referindo-se a uma situação em que "simplesmente, o progresso ainda não atingiu o Sul"). Em vez disso, os caminhos do desenvolvimento do Norte desenvolvido são explicados, inseparavelmente, a partir da exploração recorrente de colônias (no passado) e uma persistência de formas mais sutis de colonização - sem dominação territorial direta - que, como Chang (2002) de forma adequada apresentou, é colocada em prática nos dias de hoje precisamente através de estruturas vinculantes como as da OMC.

De forma auxiliar, embora também não explicitamente refletidas ou referidas no quadro formal da OMC, as análises de CGC/CGV- desde que o necessário destaque seja dado à economia política - podem ajudar a desvendar alguns dos argumentos enganosos que defendem que o "comércio mais livre" tem sido responsável por promover industrialização no Sul e, assim, o desenvolvimento, nos países em desenvolvimento. Esse tipo de análises pode ser útil no sentido de que elas podem permitir uma melhor investigação de elementos tais como: as porções dos valores gerados que são deixadas nos países em desenvolvimento quando corporações multinacionais descentralizam suas operações de produção enquanto ainda mantêm as atividades de decisão, design e concepção, e os beneficiários finais dos lucros gerados em seus 
respectivos países de origem; a medida em que as "escaladas tarifárias" ‘9 de importação existentes nas estruturas tarifárias dos países no Norte impedem o desenvolvimento de níveis mais sofisticados de progresso das cadeias de commodities dentro do território dos países do Sul que produzem as respectivas matérias-primas; e outras situações.

Assim, elas podem ajudar a descobrir ainda mais os desequilíbrios que são atualmente apresentados e permitidos no âmbito da OMC, e que são geralmente ofuscados devido ao foco da Organização nas relações entre os Estados e zonas de comércio. Nesse sentido, desenvolvimentos como o proposto por Blair (2005, I67-8) - que exige uma segunda geração de pesquisa de cadeias de commodities para olhar a forma como as cadeias são articuladas dentro e ao longo do meio social, cultural e político-econômico em que elas operam - podem ser interessantes de serem acompanhados.

\section{Conclusão}

Como vimos neste artigo, na era do "fim da história", um discurso poderoso de livre comércio, justificado sob o princípio das "vantagens comparativas", tem sido defendido e repetido como um mantra em uma tentativa de que soe verdadeiro. A OMC, instituição internacional que regula o sistema mundial de comércio, e que tem sido frequentemente vista como um dos principais símbolos de tal era, ao invés de adotar de fato a perspectiva das vantagens comparativas que ela retrata como sendo uma diretriz central do seu regulamento, na realidade, parece não só dar razão aos argumentos da teoria da dependência (de uma segregação do comércio mundial e divisão internacional do trabalho em favor das nações ricas), mas também parece tentar consolidá-la legalmente. Portanto, o que observamos, como um resultado da implementação do quadro da OMC, é uma mitigação das soberanias

I9 A "escalada tarifária" é uma situação em que um país aplica tarifas de importação muito baixas (ou mesmo nulas) às matérias-primas e define tarifas progressivamente mais proibitivas aos produtos com mais valor agregado dentro da mesma commodity ou cadeia de valor (ver: International Coffee Organization 20II). Um caso exemplar disso, que vai contra o livre comércio e premissas das vantagens comparativas defendidas pelos países desenvolvidos e pela OMC, é o do café solúvel. A Alemanha foi o principal exportador de café solúvel (instantâneo) no mundo pelo final da década de 2000 , mesmo sem ser apta para cultivar grãos de café no seu território. Em grande medida, este resultado foi associado ao fato de que, dentro da estrutura tarifária definida pela União Europeia (da qual a Alemanha faz parte), havia uma escalada tarifária relevante para produtos derivados do café. Isso permitiu à Alemanha importar regularmente grão de café barato e, ao mesmo tempo, impediu concorrentes que teriam melhores vantagens comparativas para produzir e fornecer café processado solúvel (instantâneo) para a Europa, como o Brasil, de competirem contra a Alemanha no grande mercado europeu. 
nacionais, que é reivindicada a ser feita em favor de uma liberdade coletiva supostamente melhor para todos os países no sistema (e suas respectivas populações) - analogamente às teorias contratualistas clássicas. Entretanto, o que se encontra quando se observa cuidadosamente é que, devido ao desequilíbrio das regras da OMC, e aos diferentes níveis de permissões que ela dá para os diferentes países para "distorcer os mercados" (e, assim, para ir contra o princípio de simplesmente confiar nas vantagens comparativas), alguns países acabam ficando em uma situação em que permanecem mais soberanos que outros, permitidos a praticar políticas públicas nacionais que não só trabalham em seu favor, mas, como as práticas dos países desenvolvidos têm sido vistas muitas vezes, até mesmo impõem pesados encargos sobre as perspectivas de desenvolvimento dos países em desenvolvimento.

Neste contexto, vemos que, embora o quadro da OMC não pareça formalmente reconhecer ou referir-se às perspectivas sobre comércio e desenvolvimento decorrentes de prismas como teoria da dependência ou análises de CGC/CGV, comprometer-se em explorar essas perspectivas, bem como outras que poderiam ser adicionadas, pode vir a revelar-se como uma ferramenta valiosa para permitir que se reconheça e diferencie como a própria OMC se apresenta, em comparação ao que seu quadro político realmente acaba representando na prática. Assim, em vez de simplesmente tomar como dada uma posição ingênua, nos tornamos mais capazes de reconhecer potenciais direitos adquiridos e mais poderosos para desafiar discursos monoeconômicos totalitários profundamente enraizados, como o argumento da OMC tomado como verdadeiro com relação às vantagens comparativas.

\section{REFERÊNCIAS}

Almeida, Paulo Roberto. 2004. Relações Internacionais e Política Externa do Brasil: história e sociologia da diplomacia brasileira (International Relations and Brazil's Foreign Policy). Second edition. Porto Alegre: UFRGS.

Araujo, Leandro et al. 2005. "Agricultura" (Agriculture), in Thorstensen, Vera and Marcos Jank (eds), O Brasil e os Grandes Temas do Comércio Internacional (Brazil and the Big Themes of International Trade). Sao Paulo: Aduaneiras.

Amsden, Alice. 2007. “Heaven Can't Wait”, Escape from Empire: the Developing World's Journey through Heaven and Hell. Cambridge MA: MIT Press.

Baumann, Renato; and A. M. de Paiva Franco. 2006. "The Concept of Import Substitution”, in Import Substitution in Brazil between I995 and 2000. CEPAL Review 86: 179-92. 
Blair, J.. 2005. "Global Capitalism and Commodity Chains: Looking Back, Going Forward". Competition and Change 9 (2): 153-I80.

Cardoso, Fernando Henrique. 1977. "The Consumption of Dependency Theory in the United States". Latin American Research Review, I2 (3): $7-25$.

Cedro, Rafael Rosa. 2008. "Princípios da Política Brasileira de Segurança Alimentar e o Acordo sobre Agricultura da OMC" (Principles of the Brazilian Food Security Policy and the Agreement on Agriculture of the World Trade Organization). Prismas: Direito, Politicas Públicas e Mundialização 5(2): 255-280.

Cedro, Rafael Rosa. 20II. Desenvolvimento Rural e a OMC: A Experiência do Brasil (Rural Development and the WTO: The Experience of Brazil). Curitiba: Juruá.

Cedro, Rafael Rosa; and Bruno Furtado Vieira. 20Io. “John Rawls' Justice as Fairness and the WTO: A Critical Analysis on the Initial Position of the Multilateral Agricultural Negotiation", Law and Development Review, Special Issue 20I0 - New Voices from Emerging Powers - Brazil and India, 3 (2): I2O-I4O.

Cerisier, Antoine. 20I2. Review of Bad Samaritans: The Myth of Free Trade and the Secret History of Capitalism, by Ha-Joon Chang. Social Justice First, March 3I.

Chang, Ha-Joon. 2002. Kicking Away the Ladder: Development Strategy in Historical Perspective. London: Anthem Press.

Chang, Ha-Joon. 2008. Bad Samaritans: The Myth of Free Trade and the Secret History of Capitalism.

Fairclough, Norman. 2000. "Language and neo-liberalism". Discourse and Society Guest Editorial II(2): I47-I48.

Foucault, Michel. 2004. “7 January I976”, in Society Must Be Defended: Lectures at the Collège de France, 1975-76. London: Penguin Books.

Frank, Andre Gunder. I966. "The Development of Underdevelopment", Monthly Review I8 (4): I7-3I.

Fukuyama, Francis. 1989. “The End of History?”, The National Interest (16): 3-I8.

Furtado, Celso. 1964. Development and Underdevelopment. Los Angeles: University of California Press.

Gallagher, Kevin. 2005. Putting Development First: The Importance of Policy Space in the WTO and IFIs. London: Zed Books.

Gallagher, Kevin. 2013. The Clash of Globalizations: Essays on the Political 
Economy of Trade and Development Policy. London: Anthem Press.

Gardner, Richard. I969. Sterling-Dollar Diplomacy: The Origins and the Prospects of our International Economic Order. Nova York: McGraw-Hill, Ig69.

Gereffi, Gary; and Miguel Korzeniewicz. I994. Commodity Chains and Global Capitalism. Westport: Greenwood Press.

Henning, Christoph. 2007. "Poverty and Free Trade", Blackwell Encyclopedia of Sociology Online. Accessed January 2, 20II. http://www. sociologyencyclopedia.com/subscriber/tocnode?id=g978 I405I2433I_ chunk_g978I405I2433I22_SSI-88.

Hopkins, T. K.; and Immanuel Wallerstein. I986. "Commodity Chains in the World Economy prior to I800”. Review Io (I): 157-I70.

Hudec, Robert. I975. The GATT Legal System and World Trade Diplomacy. New York: Praeger.

International Coffee Organization. 20II. The Effects of Tariffs on the Coffee Trade. Accessed November 07, 20I4. http://dev.ico.org/documents/ icc-I07-7e-tariffs-trade.pdf.

List, Friedrich. I885. The National System of Political Economy. London: Longmans, Green, and Company.

Pauweleen, Joost. 2005. “The Transformation of World Trade”. Michigan Law Review I04 (I): I-65.

Ricardo, David. I8I7. On the Principles of Political Economy and Taxation. London: John Murrey.

Talbot, John. 2004. Grounds for agreement: the political economy of the coffee commodity chain. Lanham: Rowman \& Littlefield.

Tavares, Maria da Conceição. I977. Da Substituição de Importações ao Capitalismo Financeiro (From the Imports Substitution to the Financial Capitalism), Sixth edition. Rio de Janeiro: Zahar.

Trebilcock, Michael J.; and Robert Howse. 2005. The Regulation of International Trade, Third edition. New York: Routledge.

United Nations General Assembly. I974. "Declaration for the Establishment of a New International Economic Order". United Nations General Assembly document A/RES/S-6/320I of I May I974. Accessed January 8, 20II. http://www.un-documents.net/s6r320I.htm.

WTO. 1994. "Uruguay Round Agreement: Marrakesh Declaration of April I5th I994". Accessed: January Io, 20II. http://www.wto.org/english/ docs_e/legal_e/marrakesh_decl_e.pdf.

WTO. 2007. Understanding the WTO. Third edition. Geneva: WTO. 
WTO. 2009. The World Trade Organization in Brief. Geneva: WTO. Accessed: January 30, 2009. http://www.wto.org/english/res_e/doload_e/inbr_e. pdf.

\section{RESUMO}

Este artigo explora três distintas abordagens analíticas que oferecem elementos para reflexão sobre o tema de comércio internacional - vantagens comparativas, teoria da dependência e análises de CGC/CGV - como um meio de fornecer uma análise crítica sobre o funcionamento da Organização Mundial do Comércio (OMC) e sua suposta defesa do livre comércio como um motor para o desenvolvimento.

\section{PALAVRAS-CHAVE}

Desenvolvimento; OMC; Economia Política Internacional.

Recebido em 22 de março de 2014. Aprovado em 13 de abril de 2015.

Traduzido por Isabela Souza Julio 


\section{DO CENTRO ÀS PERIFERIAS: 0 DESLOCAMENTO IDEOLÓGICO DA DIPLOMACIA DA SANTA SÉ COM O PAPA FRANCISCO}

\section{Anna Carletti ${ }^{1}$}

\section{Introdução}

Com o fim do sistema bipolar teve início um reordenamento das relações de forças em âmbito internacional devido principalmente ao surgimento de novos atores, na sua maioria, provenientes da assim chamada periferia do mundo. Após 500 anos de supremacia ocidental, os antigos centros de poder - entre os quais se destaca a China - parecem estar voltando ao cenário internacional pedindo uma inclusão qualitativa e não apenas quantitativa dentro do sistema internacional, como a que ocorreu após os processos de descolonização da Ásia e África. Trata-se de uma demanda de reestruturação internacional que leve em conta as mudanças ocorridas neste âmbito desde o fim da Segunda Guerra Mundial.

É neste cenário que surge o pontificado de Francisco, primeiro papa não europeu e primeiro papa latino-americano. O novo chefe do maior e mais influente ator religioso transnacional parece ter inaugurado um novo estágio de atuação da Igreja Católica no mundo, caracterizado por um deslocamento ideológico menos eurocêntrico e mais favorável à emergência das periferias, em sintonia com a atual demanda de reestruturação do sistema internacional apresentada por parte das nações periféricas. Através de uma leitura internacional dos primeiros anos de pontificado de Francisco, associada à análise do contexto mundial e regional - com especial ênfase na conjuntura da América Latina - que o precedeu, buscar-se-á, nesta pesquisa, evidenciar a importância

\footnotetext{
I Doutora em História e Pós-Doutora em Ciência Política pela UFRGS e Docente do curso de Relações Internacionais da Universidade Federal do Pampa. E-mail: annacarlettib@hotmail. com
} 
do papel que a Santa Sé pode desempenhar neste atual momento de reconfiguração mundial, não apenas em âmbito religioso, como também político.

Tal estudo busca contribuir também para a construção de novas categorias conceituais aptas a explicar a noção de ator religioso transnacional e sua atuação no âmbito de um sistema internacional considerado pela maioria das teorias de relações internacionais como um sistema secularizado e com pouco espaço para o fenômeno religioso.

$\mathrm{Na}$ primeira parte do artigo, vamos analisar o impacto da presença dos atores transnacionais religiosos no contexto do atual sistema internacional em transição dedicando especial atenção ao maior ator religião transnacional: a Igreja Católica.

$\mathrm{Na}$ segunda parte, serão analisadas as mudanças ocorridas de 2013 ao início de 2015 na composição e reestruturação da Cúria Romana, e, em seguida, alguns discursos e documentos do Papa Francisco e de seu novo Secretário de Estado enfatizando os que parecem ser os pontos-chave da nova diplomacia de Francisco.

Através dessa análise, procuraremos verificar a hipótese de que, nestes dois primeiros anos do pontificado, o Papa Francisco parece estar realizando um deslocamento ideológico da Santa Sé, aproximando a estrutura central da Igreja Católica, tradicionalmente ligada às elites nacionais e internacionais, às periferias do mundo político e eclesial.

\section{0 impacto dos atores transnacionais religiosos no atual sistema internacional: o caso da Igreja Católica}

Antes de falar do impacto dos atores religiosos transnacionais no atual sistema internacional faz-se necessária uma breve premissa para entendermos em que contexto tais atores religiosos ganharam relevância no cenário internacional e o porquê deste seu "inesperado" ressurgimento após séculos de aparente silêncio.

Com efeito, os acordos de Westfália, em i648, que marcaram o fim das longas guerras de religião na Europa, consagraram o princípio norteador da nova ordem internacional. A aplicação do principio cuius regio eius religio deveria garantir que, daquele momento em diante, a política dos Estados ficaria isenta de qualquer conotação religiosa. De fato, a política ligada à religião se tornou sinônimo de ameaça certa para a ordem, para segurança e para racionalidade. Era preciso, portanto, bani-la do âmbito público. Política e Religião "não poderiam coexistir nas práticas das relações internacionais" (Petito and Hatzopolous 2003, 2). As religiões perderam então sua influência em 
âmbito internacional. Os Estados nacionais foram considerados a partir de então os únicos atores capazes de influenciar a dinâmica das relações internacionais. Quando do surgimento das primeiras vertentes teóricas das relações internacionais, os Estados-nação ainda ocupavam um lugar de proeminência mesmo se começava a ser reconhecida a importância da atuação de outros possíveis atores internacionais. Contudo, o fenômeno religioso continuava sendo ignorado ou até rejeitado pelas teorias das relações internacionais que se desenvolveram a partir dos anos do entre guerras.

Nas últimas décadas, porém, registrou-se um ressurgimento do fenômeno religioso que suscitou, ao mesmo tempo, surpresa e interesse entre os analistas de política internacional. A partir do final da década de I980, e, sobretudo, após os acontecimentos do dia II de setembro de 200I, a análise do fenômeno religioso no âmbito dos estudos de política internacional vem conquistando mais espaço. O fator "esquecido", usando a expressão de Petito e Hatzopolous (2003), parece ter voltado do exílio, sendo considerado atualmente, por alguns analistas (Dosdad 2006; Ferrara 20I4), entre os elementos-chave cuja compreensão poderia auxiliar numa análise mais ampla e profunda dos eventos mundiais e do mundo em transformação.

No âmbito desta reavaliação da importância do fenômeno religioso, ao lado dos atores estatais e não estatais reconhecidos tradicionalmente como agentes influenciadores das dinâmicas internacionais, destacam-se de forma cada vez mais proeminente também os atores transnacionais religiosos que, de acordo com Haynes (2009), indubitavelmente afetam tanto a política interna que a política internacional dos Estados. Ao lado dos movimentos evangélicos norte-americanos, outros atores religiosos transnacionais são os movimentos islâmicos moderados ou extremistas, grupos nacionalistas hindus, fundamentalistas judeus, a Igreja Católica, entre outros.

Tais atores transnacionais religiosos possuem em comum a capacidade de atuar nas relações internacionais interagindo com grupos que possuem metas semelhantes e ultrapassando os limites estatais visam alcançar seus interesses vitais. Isso é possível apenas pela realidade atual da sociedade globalizante onde as barreiras de comunicação diminuíram e as redes nacionais em nível global não encontram grandes obstáculos, o que potencializa as capacidades destes atores transnacionais de ultrapassar as fronteiras dos Estados Nacionais e se tornar forças significativas que podem contribuir para moldar os acontecimentos internacionais (Haynes 2009).

Entre os maiores atores religiosos transnacionais, a Santa Sé e consequentemente a Igreja Católica Romana, contando com mais de I bilhão de fiéis no mundo todo, destaca-se no cenário internacional principalmente por possuir 
(...) uma ligação especial entre autoridade espiritual e autoridade temporal, pela combinação entre a organização de uma religião e a estrutura de um estado, pela superposição entre o sagrado e o soberano. O papa é ao mesmo tempo Somo Pontífice da Igreja e Poder Executivo do Estado do Vaticano (Turzi 2013, 30).

A Santa Sé, o órgão de governo da Igreja Católica é a única instituição religiosa no mundo que tem a prerrogativa de manter relações diplomáticas com os Estados. Atualmente, a Santa Sé possui representantes diplomáticos em I77 países além de manter observadores permanentes em organismos internacionais, como a Organização das Nações Unidas, entre outras.

Mesmo sendo considerado um Estado com todas as características constitutivas desta instituição política, a Santa Sé permanece um ator estatal sui generis. Os interesses que a Santa Sé persegue não são econômicos nem militares. Mesmo tendo dois corpos de segurança: os Guardas Suíços e o corpo de Gendarmaria ${ }^{2}$, a Santa Sé não possui os tradicionais recursos de poder do Hard Power, que qualificam a importância de um país no cenário internacional. Então, que tipo de relações de forças distingue a atuação da Santa Sé no cenário internacional?

Ao se utilizar o conceito de Joseph Nye acerca da força do Soft Power, definido como poder de atração e de convencimento ao invés de coerção ou recompensa, pode-se pensar que a Santa Sé tenha utilizado como base de sustentação de seu agir internacional justamente este tipo de poder, chamado poder brando, ou Soft Power descrito também como resultado de uma série de elementos de difícil mensuração, mas que envolvem diferentes dimensões.

A Santa Sé faz uso desse poder através de uma rede capilar de igrejas locais, instituições sociais e educativas distribuídas em todo o planeta. Sua mensagem é escutada mesmo pelos que não fazem parte desta instituição. Suas ações, positivas ou negativas repercutem nos meios de comunicação mundiais. Os escândalos financeiros e sexuais minaram a credibilidade e legitimidade da Igreja Católica, sobretudo nos últimos dois pontificados, o de João Paulo II e de Bento XVI. Papa Francisco, desde sua primeira aparição,

\footnotetext{
2 Ambos os Corpos tem a tarefa de defender o Estado da Cidade do Vaticano. Os Guardas Suíços têm suas origens em 1506 , quando foram recebidos como exército permanente pontifício pelo papa Júlio II. O Corpo da Gendarmaria foi criado sob o papa Pio VII, em I8ı6, abolido em I970, ressurgindo em I99I. Atualmente, o corpo de Gendarmaria, de uniforme azul, é constituído de cerca de Ioo agentes devidamente treinados, provenientes de repartições antiterroristas e que agem protegendo o papa e vigiando os ingressos nas portas dos muros vaticanos. Quando das viagens papais, cabe a eles a segurança do papa, em acordo com as autoridades da polícia do país que recebe a visita.
} 
parece buscar reestabelecer a credibilidade da Igreja perdida nas últimas décadas.

\section{As tentativas revolucionárias do primeiro papa latino- americano}

Desde a eleição do Papa Francisco muito se discutiu e muito se escreveu sobre a possível influência da proveniência geográfica do novo papa em relação ao futuro da Igreja Católica. Papa Francisco não é apenas o primeiro papa não europeu, mas também o primeiro papa latino-americano, isto é, um papa que nasceu, cresceu e viveu no sul do mundo, na periferia do poder tanto político e eclesial. Contudo, isto não seria um condicionamento suficiente para explicar os novos rumos que Francisco está empreendendo.

Um dos papáveis durante o conclave que elegeu o cardeal Bergoglio era também latino-americano, mas pertencente ao lado conservador da Igreja Católica. Então, o fato de ser latino-americano não explicaria completamente este deslocamento. Ao lado de sua latinidade, lembramos que Francisco é jesuíta. A Companhia de Jesus é uma das mais antigas ordens religiosas onde a componente comunidade, junto com estudo, obediência e discernimento é variável importante a ser considerada para entender a postura adotada por Bergoglio. O fato do Papa Francisco ter escolhido viver na Casa Santa Marta em contato de muitas pessoas, ao invés que residir no apartamento reservado ao papa - comparado por Francisco como um funil ao contrário, onde o acesso é estreito, e se entra com o conta-gotas (Spadaro 2013) - pode ser explicado justamente pela importância vital dada por Francisco à vida de comunidade. Outro elemento importante a ser considerado é sua experiência pastoral a frente de uma arquidiocese como a de Buenos Aires. Por isso escolhemos percorrer de forma introdutória a biografia do novo papa procurando colocar em evidência elementos que poderiam nos levar a uma compreensão mais clara das escolhas do novo papa.

\subsection{Notas Biográficas de Papa Francesco}

Papa Francisco - Jorge Maria Bergoglio - nasceu em I7 de dezembro de 1936 em Buenos Aires. Sua família - pai ferroviário, mãe dona de casa era originária da região do Piemonte (noroeste da Itália). Bergoglio, após ter ingressado no seminário diocesano, o deixou para se tornar jesuíta (Spadaro 20I3). Estudou teologia antes na Argentina, e depois na Alemanha onde conseguiu seu doutorado em Teologia. Após seu regresso na Argentina, foi 
nomeado provincial dos jesuítas (da Argentina e Paraguai), exercendo esta função de I973 a I979. Em I976, a junta militar chegou ao poder através de um golpe de Estado, instaurando um regime repressivo que durará até I983.

Bergoglio, como revelou em uma entrevista ao jesuíta Antonio Spadaro na revista "La Civiltà Cattolica", desempenhou a função de provincial sem ter tido nenhuma experiência anterior de como gerir uma comunidade. Quando assumiu o cargo, aos 36 anos, adotou uma postura autoritária que lhe procurou críticas e acusações de ultraconservadorismo. Contudo, graças àquela difícil experiência, quando anos depois foi nomeado Arcebispo de Buenos Aires, a atitude escolhida foi completamente diferente (Spadaro 2013).

Em I992, foi nomeado Bispo Auxiliar de Buenos Aires e em I998, Bergoglio foi nomeado Arcebispo de Buenos Aires. João Paulo II o criou cardeal em 200I. Entre 2005 e 20II, foi Presidente da Conferência Episcopal da Argentina. Como mencionado, desta vez a experiência de governo foi mais positiva que a de provincial. Aos 56 anos, Bergoglio aprendeu que "governar não era dar ordem, mas escutar, criar consenso, resolver problemas permitindo-se o tempo de avaliá-los com profundidade" (Politi 20I4, I39). Como arcebispo de Buenos Aires, privilegiou o estreito contato com os sacerdotes de sua diocese encorajando-os a praticar a misericórdia. Sua pastoral ficou conhecida pela sensibilidade aos problemas sociais.

Frequentemente, de ônibus ao invés que de carro, visitava as villas (os bairros mais pobres na grande Buenos Aires), participando das reuniões dos padres que trabalhavam com os mais pobres. Parava para conversar com os cartoneros, os que recolhiam o lixo na cidade de Buenos Aires. Bergoglio sentiu na pele os grandes problemas de uma metrópole com seu pluralismo cultural e suas contradições. Retratando as origens do novo papa, Politi evidencia a grande diferença do Papa Francisco em relação aos pontífices que o precederam:

Francisco é o primeiro papa nascido, crescido e que viveu numa metrópole contemporânea. $\mathrm{O}$ pontífice argentino, mesmo proveniente de uma área distante da Europa, é o único que se nutriu da experiência tumultuosa, dramática e variegada de uma cidade gigantesca, ao redor da qual gravitam treze milhões de habitantes. Ratzinger, Roncalli, Wojtyla e Luciani são todos nascidos em cidadezinhas de província e mesmo durante suas carreiras ignoraram o ritmo da metrópole (Politi 20I4, I40).

O contato diário com o povo argentino - ele preferiu morar num pequeno monolocal ao invés que na residência episcopal - incentivou seu empenho, como arcebispo, de combater as desigualdades sociais, denunciando 
abertamente aqueles que ele considerava responsáveis pelo sofrimento do povo, entre estes o governo argentino do Nestor Kirchner. Tal postura, se por um lado aumentou sua popularidade entre o povo, de outro lhe causou bastantes problemas com as autoridades políticas. Com efeito, já no final de 20Iо, o cardeal Bergoglio foi publicamente apontado como "colaboracionista" durante a ditadura militar. Os relatos difundidos pelos principais jornais de Buenos Aires - alinhados ao governo Kirchner - indicavam que Bergoglio, em i976, quando provincial dos jesuítas, teria traído dois sacerdotes de sua ordem, Yorio e Jalics, que foram presos e torturados. Uma vez soltos, os dois sacerdotes se refugiaram em Roma, acolhidos pelo Superior Geral dos Jesuítas, Pedro Arrupe, permanecendo no silêncio por muitos anos e deixando esta dúvida sobre a atitude de Bergoglio pairando no ar até sua eleição. De acordo com Frattini (20I4), os jornais próximos ao governo Kirchner preocuparam-se em alimentar esta dúvida que veio a tona de novo após a eleição de Bergoglio como novo Papa. Somente então, o silêncio de um dos dois sacerdotes foi quebrado. Padre Jalics vive atualmente na Alemanha, e após a eleição de Bergoglio afirmou que eles não foram traídos pelo então provincial. De acordo com suas informações, ele nunca os denunciou. Haviam acreditado nisso até o final dos anos 90 quando graças a conversações que eles tiveram entenderam qual era a verdade.

A visita da presidente Cristina Kirchner em I8 de março de 20I3, logo após sua eleição foi interpretada como sinal de trégua entre Bergoglio e o governo argentino.

\subsection{Os primeiros passos da Reforma da Cúria Romana, do Papado e da Igreja Católica}

Durante as reuniões pré-conclave das congregações gerais ocorridas de 4 a II março de 2013 , três propostas ganharam a aprovação dos cardeais: reformar a cúria, tornando-a mais simples e eficiente, fazer limpeza no banco do vaticano e promover a colegialidade, instaurando consultas frequentes entre o papa, o colégio cardinalício e as conferências episcopais nacionais (Politi 20I4).

Na entrevista a Antônio Spadaro da revista La Civiltà Cattolica, fazendo referência à reforma da Cúria e às competências dos dicastérios que a compõem, afirmou que estes "estão a serviço do papa e dos bispos: devem ajudar tanto as Igrejas particulares quanto as conferências episcopais [...] se forem mal entendidos, correm o risco de se tornar organismos de censura. Os dicastérios romanos são mediadores, não intermediares ou gestores" (Spadaro 20I3). De acordo com Politi (2OI4), isso já representaria uma revolução, pois 
o que era considerado até agora apenas um instrumento totalmente a serviço do papa, deverá se transformar em um mecanismo de ajuda e de ligação entre o papado e os episcopados do mundo.

Outro ponto abordado na entrevista foi a maior autonomia desejada pelo papa Francisco para as Conferências episcopais locais. Por exemplo, lembrando a quantidade de denuncias de falta de ortodoxia que chegam a Roma, Papa Francisco afirmou que "estes casos deveriam ser estudados pelas Conferências episcopais locais, às quais pode chegar uma ajuda válida de Roma. Os casos, de fato, se tratam melhor no lugar" (Spadaro 2013).

Tal decisão, se concretizada, constituiria uma ruptura com a postura adotada por Bento XVI. Com efeito, para Ratzinger as conferências nacionais não seriam parte integrante da estrutura da Igreja, cabendo-lhe apenas uma função pratica (Ratzinger 2000). Deste ponto de vista, Bento XVI defendia a manutenção de uma Igreja vertical de tipo imperial onde Roma ditava lei às sedes nacionais, enquanto o Papa Francisco está trabalhando para que a Igreja se torne uma instituição participativa, cuja atuação seja horizontal através de colaboração efetiva entre o governo central de Roma e as igrejas nacionais.

Em I3 de abril de 20I3, a exatamente um mês de sua eleição, Papa Francisco deu concretamente o primeiro passo em direção à tão esperada reforma da Cúria Romana: a criação de um grupo de oito Cardeais mais um Secretário com o objetivo de aconselhar o papa no governo da Igreja Católica e no projeto de revisão da Constituição Apostólica "Pastor Bonus", de I988, que regulamenta e estrutura o funcionamento da Cúria Romana.

Os Cardeais que integram o Conselho consultivo do papa são provenientes de todos os continentes e, com exceção do Governador do Estado da idade do Vaticano, o Cardeal Giuseppe Bertello, nenhum deles pertence à Cúria Romana. Após o ingresso no grupo do Secretário de Estado, Pietro Parolin, o grupo passou a ser chamado extraoficialmente de C9.

Desde sua criação, o Conselho se reúne a cada dois meses, na residência do papa, Casa Santa Marta. As reuniões duram três dias com a participação constante do papa. Após as primeiras reuniões, o Conselho chegou à conclusão que não vai ser suficiente reformar a Constituição "Pastor Bonus" de João Paulo II. Será preciso redesenhar "ex-novo o modelo de Cúria após séculos de poder ultra-centralizado". (Politi 20I4, I49).

\subsubsection{Renovação do Colégio Cardinalício}

Nos dois anos de pontificado, Papa Francisco nomeou 3I novos cardeais eleitores que vêm renovar o Colégio dos Cardeais da Igreja Católica. De 
acordo com o Cânone 349 do Código de Direito Canônico de I983, cabe ao Colégio dos Cardeais providenciarem a eleição do Romano Pontífice, além de assistir o papa "quer agindo colegialmente, quando forem convocados para tratar em comum dos assuntos de maior importância, quer individualmente, nos vários ofícios que desempenham, prestando auxílio ao Romano Pontífice na solicitude quotidiana da Igreja universal"3.

O Colégio dos Cardeais foi instituído em II50. O número dos cardeais integrantes cresceu com o passar dos séculos. No pontificado de Paulo VI foram estabelecidas regras quanto ao número máximo, estabelecido em I20, e quanto à idade máxima dos eleitores dispondo que ao cumprimento do $80^{\circ}$ ano, os Cardeais perdem o direito de entrar no Conclave. Mas o que chama mais a atenção na análise da criação dos cardeais eleitores durante os últimos pontificados é a proveniência geográfica destes cardeais. Durante os pontificados de João Paulo II e Bento XVI, a maioria dos cardeais eleitores veio da Europa, principalmente de nações próximas à região de origem dos pontífices, e os membros da Cúria Romana. Também neste caso, Francisco escolheu um caminho diferente. Os cardeais escolhidos pelo Papa Bergoglio vêm de todos os continentes, com evidente diminuição da percentagem dos europeus em relação aos pontificados que o precederemos como podemos visualizar nos gráficos que seguem.

\section{Cardeais criados por João Paulo II}

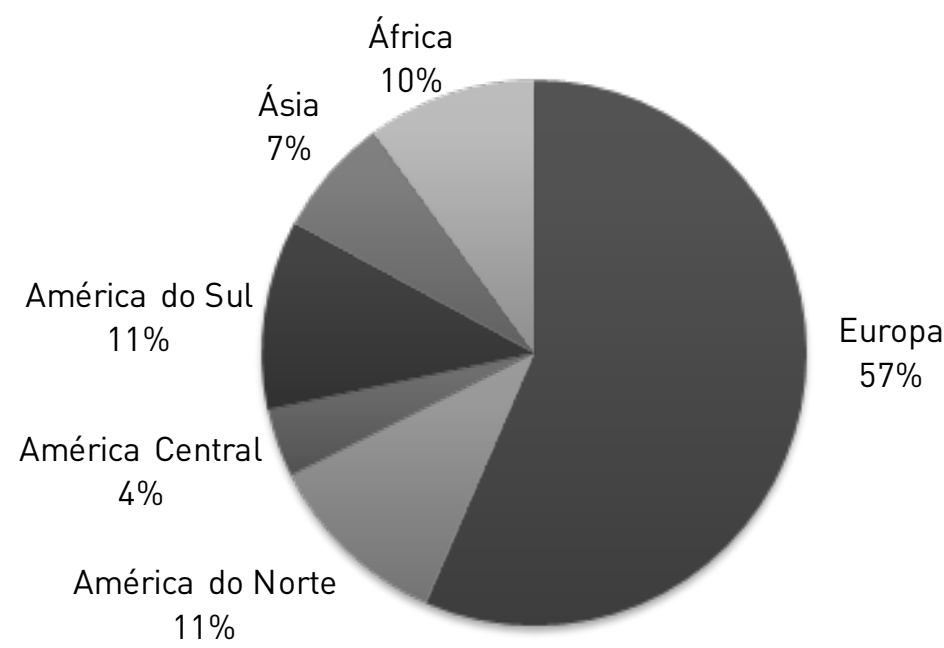

Fonte: http://www.vatican.va

3 Código de Direito Canônico. Disponível em: http://www.vatican.va/archive/cod-iuris-canonici/portuguese/codex-iuris-canonici_po.pdf. Acesso em: 27 mai. 2014. 
Cardeais criados por Bento XVI

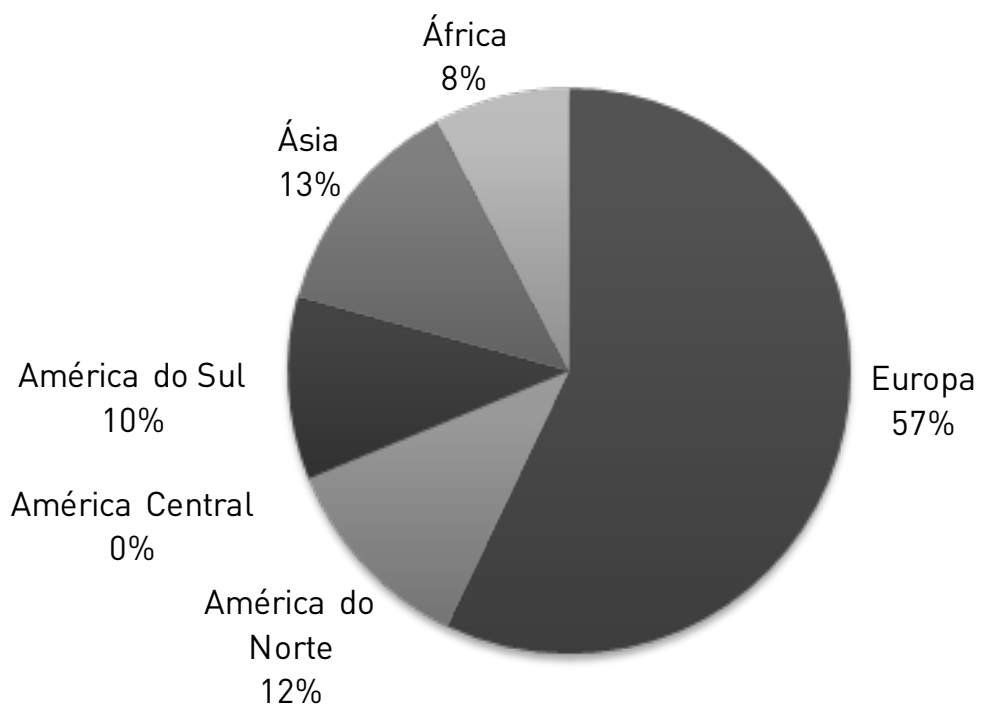

Fonte: http://www.vatican.va

\section{Cardeais criados por Francesco}

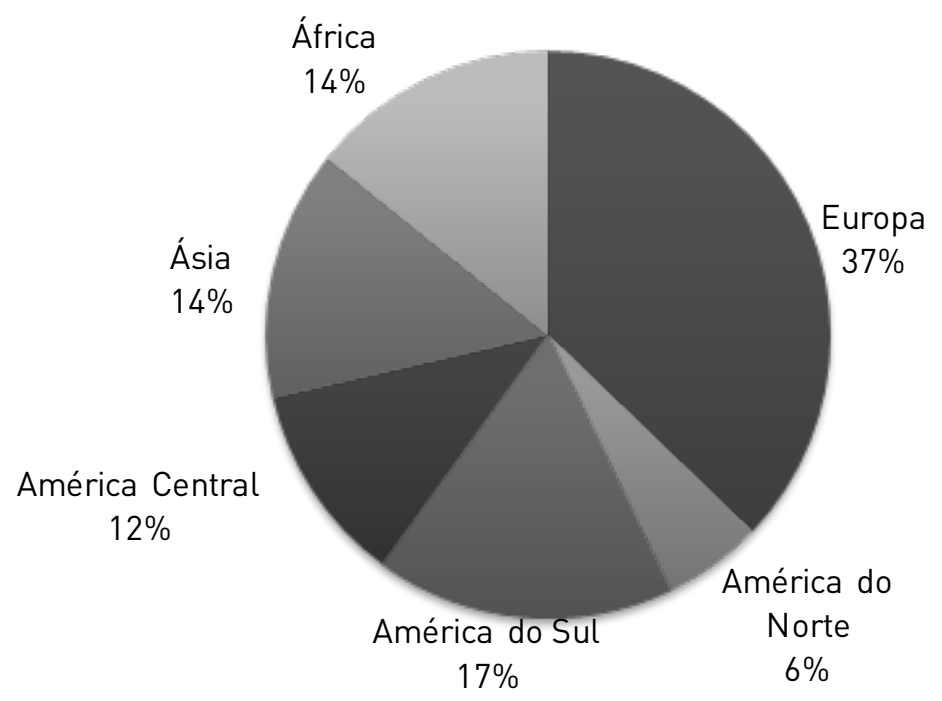

Fonte: http://www.vatican.va 
O gráfico que segue mostra a distribuição geográfica dos cardeais que compõem atualmente o Colégio Cardinalício.

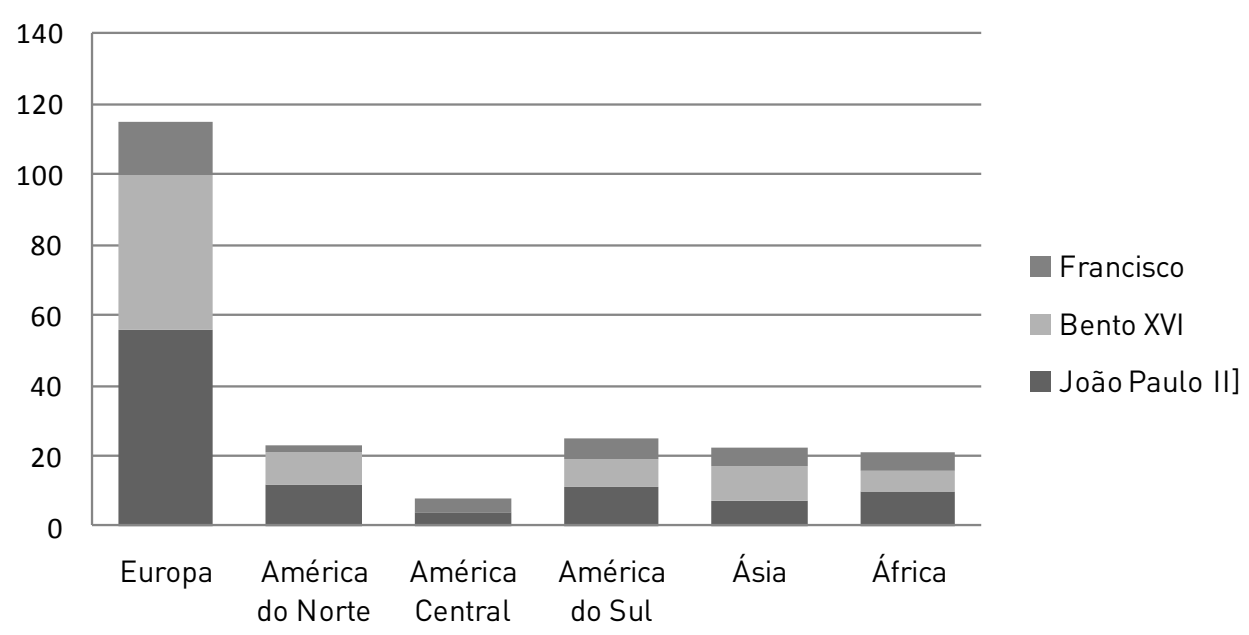

Fonte: http://www.vatican.va

Ainda há uma disparidade entre a Europa e os outros continentes, disparidade esta, que é o resultado da escolha feita sob os pontificados de João Paulo II e Bento XVI. Contudo, calcula-se que daqui a alguns anos o Papa Francisco deverá ter renovado mais da metade do corpo eleitoral do papa que o substituirá, deixando um Colégio de Cardeal mais representativo de todos os continentes onde o peso da Europa e, sobretudo o domínio tradicional dos italianos, deverá diminuir de forma considerável. De acordo com Politi "o futuro do catolicismo já não está mais no velho continente, mas entre os povos do Terceiro mundo. O pontífice reforçou particularmente a componente da América Latina, onde vive quase a metade dos católicos do planeta" (Politi 20I4, 238).

\subsubsection{Mudanças revolucionárias no papado e na Igreja Católica}

Desde o início de seu pontificado, Papa Francisco mostrou que o caminho que iria escolher seria de mudança, a começar pelo nome que nunca fora escolhido antes por nenhum papa. Além disso, Bergoglio se recusou em ser chamado Francisco I, provavelmente porque esta numeração ao lado do nome pode lembrar mais uma dinastia imperial que o título de um chefe religioso. Por último, ele deixou claro que o nome escolhido não se referia tanto ao missionário espanhol jesuíta Francisco Xavier que conquistou a Ásia, quanto a Francisco de Assis, o santo que desafiou a rica e corrupta Igreja 
Medieval apresentando-se como representante de uma igreja extremamente despojada de riquezas e de títulos.

As referências à pobreza como característica indispensável da Igreja Católica e de seus representantes são elementos constantes nos documentos oficiais do Papa Francisco desde 20I3, ano de sua eleição.

A reforma do IOR (Instituto para as Obras da Religião), conhecido mais popularmente como banco do Vaticano, é considerada um dos primeiros passos dado pelo novo papa em direção à reforma do Vaticano. Tal reforma - iniciada já no primeiro ano de seu pontificado - está sendo caracterizada pela busca de limpeza total nos movimentos financeiros do Vaticano, pelo aumento da transparência e pela mudança de diretores que se envolveram em escândalos.

Ainda no final de 2013, Papa Francisco instituiu um Conselho para a Economia criado para vigiar a gestão econômica e a atividade administrativa e financeira de todas as estruturas da Santa Sé. O Conselho é constituído por oito bispos e sete profissionais leigos. O presidente é o Cardeal de Munique, Reinhard Marx, também membro do C9 que auxilia o papa no governo da igreja Católica.

Além da reforma das finanças, o estilo de condução da Igreja Católica e de seus representantes parece estar sob acusação no novo pontificado.

Já em sua primeira visita internacional ao Brasil, o Papa Francisco dirigindo-se aos bispos responsáveis do Conselho Episcopal Latino-Americano (CELAM), chamou atenção para o perigo do clericalismo evidenciando as características que os bispos deveriam apresentar.

Os Bispos devem ser Pastores, próximos das pessoas, pais e irmãos, com grande mansidão: pacientes e misericordiosos. Homens que amem a pobreza, quer a pobreza interior como liberdade diante do Senhor, quer a pobreza exterior como simplicidade e austeridade de vida. Homens que não tenham "psicologia de príncipes". (Papa Francisco 20I3).

No final de 20I4, o discurso do Papa Francisco aos Cardeais e Bispos da Cúria Romana, ganhou destaque na mídia internacional. O papa aproveitou da oportunidade de se reunir com Cardeais e Bispos da Cúria Romana, em ocasião do Natal, para apresentar-lhe uma lista das quinze doenças que afetariam a Cúria Romana. Entre elas, o papa destacou a doença de se sentir imortais, a da excessiva operosidade, a do endurecimento mental e espiritual, do excessivo planejamento, a doença do Alzheimer espiritual, da rivalidade e da vanglória, da esquizofrenia espiritual, das fofocas, da indiferença e da 
acumulação, dos círculos mundanos, do lucro mundano e dos exibicionismos entre outras (Papa Francisco 20I4). Após o discurso, reuniu-se com os funcionários do Vaticano e seus familiares aos quais apresentou seu pedido de perdão: "Não quero terminar este encontro de bons votos sem vos pedir perdão pelas faltas, minhas e dos meus colaboradores, e também por alguns escândalos, que fazem muito mal. Perdoai-me." (Papa Francisco, 20I4).

O diagnostico da Cúria Romana, traçado com tanta clareza por Papa Francisco naquela ocasião, lhe atraiu críticas não apenas no território do Vaticano, como também nos ambientes mais conservadores do catolicismo italiano e internacional.

Sua rebelião em abraçar o estilo de vida de seus predecessores foi considerada um atentado à tradição que sustentou o papado ao longo de sua história. Os mais conservadores a interpretaram como uma crítica aos pontífices que o precederam, uma crítica ao modelo de Igreja tradicional compreendida como intocável estrutura central de poder da Igreja católica. Teme-se que Francisco, com sua simplicidade, possa diminuir a sacralidade da pessoal papal (Politi 20I4).

Sempre de acordo com Politi $(2014,232)$ "remodelar e simplificar a cúria significaria em perspectiva uma perda de poder, de influência de carreira e também de dinheiro de certa classe burocrático-eclesiástica, que se perpetua há séculos".

As críticas que os cardeais e bispos pertencentes a este grupo não podem manifestar abertamente, são veiculadas através de inúmeros sites e jornais tanto italianos que estrangeiros.

Não obstante os contínuos ataques dos meios de comunicação, o Papa Francisco parece estar avançando com decisão e firmeza, mesmo tendo ciência que os anos de seu pontificado - que seus opositores desejam seja breve - não serão suficientes para finalizar as reformas necessárias para mudar o rumo de uma Igreja até agora guiada por princípios monárquicos.

Uma das estratégias que o Papa Francisco parece estar usando é a de se circundar de pessoas competentes e profissionais em sua área de atuação que o ajudem a tornar tais mudanças eficazes e elevem o nível de preparação e atuação dos representantes da Igreja Católica. Exemplo disso, a constituição do C9, do qual falamos anteriormente e a mudança de seus colaboradores naquela é considerada uma das mais importantes áreas de atuação da Santa Sé, a dimensão internacional do papado.

Tal dimensão está adquirindo mais visibilidade justamente pelo deslocamento ideológico do Papa Francisco, cuja atenção está voltada mais às periferias do planeta que aos centros tradicionais de poder. 


\subsection{A nova diplomacia do Papa Francisco}

A escolha da proveniência geográfica dos novos cardeais parece demonstrar uma especial atenção do papa em garantir um maior equilíbrio entre centro e periferias. Mesmo sendo ainda alto o número de cardeais da Europa, com o tempo a tendência parece ser aquela de fortalecer a contribuição das "periferias" contrabalanceando o peso até então tido pela Cúria Romana e pela Igreja Europeia. Fortalecendo as Igrejas locais, se garantiria uma maior descentralização das relações de força na própria Igreja Católica, uma demanda que remonta ao Concílio Vaticano II, mas que até agora tinha ficado apenas no papel.

Reforça esta hipótese a análise das metas das viagens realizadas pelo papa nestes dois anos e meio de pontificado. Ao listar as metas internacionais já visitadas: Brasil, Turquia, Albânia, Coreia do Sul, Terra Santa, Sri Lanka e Filipinas, Bósnia-Herzegovina, Equador, Bolívia, Paraguai e a próxima visita a Cuba, se tem a impressão que a predileção do Papa Francisco em relação às periferias do mundo não permaneceu só na retórica. Os países que ele visitou são países que estão ou na periferia da Europa, ou na região chamada de sul do mundo, caracterizada por um passado ou presente de conflitos ou/e de exclusão, ou de marginalização do centro mundial político ou econômico.

As próprias visitas na Itália foram realizadas, na sua maioria em cidades ou cidadezinhas periféricas. Se observarmos com atenção a maneira de agir ou de falar do Papa Francisco nota-se que desde o início ele escolheu certa forma de governar: poucos colaboradores, mas bem formados que o auxiliem a ver e entender o panorama internacional em que a Igreja Católica está inserida para que ele possa tomar a decisão final. Entre estes colaboradores, a escolha do Secretário de Estado de um papa é considerada uma das mais estratégicas para o sucesso de um pontificado. A figura do Secretário de Estado corresponde na Santa Sé ao Primeiro Ministro ou ao Ministro das Relações Exteriores dos outros Estados.

Durante o pontificado de Bento XVI, por exemplo, a figura de seu Secretário de Estado, Tarciso Bertone sofreu bastante desgaste e não ajudou o já complexo pontificado de Bento XVI.

O novo Secretário de Estado do Papa Francisco não é um canonista como Tarcisio Bertone, mas um diplomata experiente que, Francisco, talvez não por acaso foi buscar na sua região de origem, a América do Sul.

Pietro Parolin, italiano, nascido em I955, quando chamado pelo Papa Francisco, encontrava-se na Venezuela onde, desde 2009, exercia as funções de Núncio Apostólico. Chegara na Venezuela após ter acumulado bastante 
experiência internacional. Além das experiências na Nigéria e no México, Parolin trabalhou io anos na Secretária de Estado durante os quais aprofundou seu conhecimento das principais questões geopolíticas do continente asiático: o conflito Palestina/Israel e as delicadas relações com o Vietnã. Criado Cardeal em 20I4, pelo Papa Francisco, participa regularmente das reuniões do Conselho de Cardeais (C9).

Para entendermos os pontos-chave do pensamento diplomático de Papa Francisco, escolhemos três documentos que manifestam tal pensamento, a saber, as duas Lectio Magistralis, proferidas em nome do papa pelo Cardeal Parolin, respectivamente em março de 20I5, na Pontifícia Universidade Gregoriana de Roma e, em abril de 20I5, na Faculdade de Teologia do Triveneto, mais a Exortação Apostólica Evangelii Gaudium, escrita por Papa Francisco em 20I3, quase um manifesto de intenções sobre o futuro de seu pontificado.

Na Lectio Magistralis proferida em março, abordando os objetivos da ação diplomática da Santa Sé, o Secretário de Estado primeiramente sublinha a postura pró-ativa da diplomacia da Santa Sé quando afirma que "ela não pode se contentar do papel de voz crítica, sendo chamada a atuar para facilitar a coexistência e a convivência entre as várias nações" (Parolin 20I5).

Para que a Santa Sé possa ter os meios adequados para que esta atuação seja efetiva e incisiva, Papa Francisco, propôs que no espaço da Secretaria de Estado volte a funcionar um Escritório para a mediação pontifícia que funcione de elo entre as atividades que a diplomacia da santa Sé já desempenha em diferentes países e também se coligar às atividades que desempenham neste âmbito as Instituições Internacionais. Nos anos 80, durante o pontificado de João Paulo II foi criado este Escritório dentro do Conselho para os Assuntos Públicos, que hoje é conhecida como Secção para as relações com os Estados da Secretaria de Estado. A tarefa deste Escritório era desenvolver conteúdos jurídicos-políticos que auxiliassem na resolução da disputa territorial entre a Argentina e Chile sobre o Canal de Beagle, no extremo sul do Continente americano.

A função de arbitragem e mediação pode ser considerada uma das atuações tradicionais ao longo da história da Santa Sé e de suas relações com os países. Parolin lembrou que estas mediações estão profundamente ligadas à dimensão eclesial, justamente porque foi pela presença e pelo papel da Igreja nos países diretamente interessados que a intervenção diplomática da Santa Sé foi considerada essencial (Parolin 20I5).

No mês seguinte, Parolin proferiu nova Lectio Magistralis dessa vez dirigida à comunidade acadêmica da Faculdade de Teologia do Triveneto, durante a qual evidenciou a visão do papa frente aos desafios do mundo atual. Muitos dos elementos desta conferência coincidem com os temas tratados 
pelo papa na Exortação Apostólica Evangelii Gaudium.

De acordo com Parolin, a visão que o Papa Francisco tem do mundo é a de um mundo aberto, onde em princípio não existem situações ou costumes pré-constituídos.

Este Papa que vem de longe, do fim do mundo, como ele disse no dia de sua eleição, olha à Europa e ao mundo com um olhar diferente, descentrado e distante daquela visão que acompanha a tradicional leitura teológica. Ele não pertence nem ao Oriente, nem ao Ocidente, como também não provém do coração do sistema internacional; por isso seu ensinamento desconcerta nossa habitual perspectiva e de certa forma revira nossa forma de ver o mundo e a Igreja. Como bom jesuíta, ele exerce seu discernimento e se coloca na busca da vontade de Deus para perscrutá-la e assim se preparar a tomar decisões sobre a terra: o que há de mais geopolítico e teológico ao mesmo tempo? (Parolin 20I5).

Ser o primeiro papa não europeu, e o primeiro papa latino-americano, certamente influencia a visão e abordagem dada por Bergoglio ao seu pontificado.

Ele não possui a dívida moral que os europeus assimilaram voluntariamente ou involuntariamente em relação aos Estados Unidos, como consequência dos horrores dos dois Conflitos Mundiais. Ao contrário ele viveu em sua própria pele o duro impacto da política de Segurança atuada pela superpotência norte-americana na América Central e América do Sul durante o período da Guerra Fria. Tais experiências possibilitam ao pontificado de Francisco um olhar diferente não do centro às periferias como foi o olhar tradicional dos papas que o precederam, mas das periferias ao resto do mundo. Foge à abordagem de Francisco a possibilidade de se aliar a um país hegemônico para levar para frente os objetivos da Igreja Católica, como aconteceu em diferentes papados. A preferência de Francisco parece ser um mundo multipolar onde as diferenças ao invés de dividir podem acrescentar e potencializar a busca das nações periféricas por um mundo menos desigual.

De acordo com Parolin, no novo pontificado de Francisco

(...) as periferias devem estar no centro das preocupações dos países que por condição social, política, econômica, territorial são os protagonistas do sistema internacional, como também das instituições internacionais chamadas a programar e gerenciar a cooperação e às suas ações. Somente englobando as periferias é possível ativar programas e ações inspirados pela solidariedade e não finalizados à assistência (Parolin 20I5). 
E para alcançar os excluídos, as periferias, a diplomacia da Santa Sé é considerada um instrumento privilegiado.

Se os governos realizam aquela que é chamada a "razão de estado" exercitando um Hard Power através da potência econômico-financeira ou das armas, a Santa Sé deve levar a cabo uma "razão da Igreja" através de um Soft Power feito de conviç̧ões e de comportamentos exemplares. Ela deve trabalhar, também através da ação diplomática, para criar mais justiça, primeira condição da paz (Parolin 20I5).

\subsection{Papa Francisco e os ataques ao capitalismo}

O tema da justiça social é outro argumento recorrente nos documentos do papa Francisco. A Exortação Apostólica Evangelii Gaudium de 2013 - e a Enciclíca sobre a questão ambiental, Laudato Sí, publicada há algumas semanas, apresentam fortes críticas ao atual sistema econômico cujas contradições são apontadas pelo Papa Francisco como as causas mais profundas dos problemas da sociedade de hoje. Papa Francisco não hesita em afirmar que "o sistema social e econômico é injusto na sua raiz” (PAPA FRANCISCO, 20I3, p. 50).

Assim como em Buenos Aires Bergoglio criticava a corrupção do governo argentino, como papa, hoje ele crítica o sistema mundial apoiado unicamente numa lógica de mercado.

Não podemos mais confiar nas forças cegas e na mão invisível do mercado. O crescimento equitativo exige algo mais do que o crescimento econômico, embora o pressuponha; requer decisões, programas, mecanismos e processos especificamente orientados para uma melhor distribuição das entradas, para a criação de oportunidades de trabalho, para uma promoção integral dos pobres que supere o mero assistencialismo. Longe de mim propor um populismo irresponsável, mas a economia não pode mais recorrer a remédios que são um novo veneno, como quando se pretende aumentar a rentabilidade reduzindo o mercado de trabalho e criando assim novos excluídos. (Ibid, I68)

A solidariedade é apontada por Francisco como elemento fundamental que deve estar presente nas relações mundiais, e antídoto ao atual sistema econômico que gera exclusão, pobreza e cultura do descarto junto à maioria da população mundial. 
Enquanto os lucros de poucos crescem exponencialmente, os da maioria situam-se cada vez mais longe do bem-estar daquela minoria feliz. Tal desequilíbrio provém de ideologias que defendem a autonomia absoluta dos mercados e da especulação financeira. Por isso, negam o direito de controle dos Estados, encarregados de velar pela tutela do bem comum. Instaura-se uma nova tirania invisível, às vezes virtual, que impõe, de forma unilateral e implacável, as suas leis e as suas regras. (Ibid, 50)

Na Encíclica Laudato Sí, após elencar os problemas mais graves relacionados ao degrado do meio ambiente, Papa Francisco evidencia a profunda ligação entre o degrado ambiental e as condições de pobreza e injustiça social que afetam ainda a maioria da população mundial, e que resulta numa situação de desigualdade planetária. Com efeito, de acordo com Papa Francisco, não existiria apenas desigualdade entre os indivíduos, mas também entre os países, o que obrigaria a pensar numa ética das relações internacionais para refletir sobre a dívida "ecológica" que existe entre o Norte e o Sul.

A dívida externa dos países pobres transformou-se num instrumento de controle, mas não se dá o mesmo com a dívida ecológica. De várias maneiras os povos em vias de desenvolvimento, onde se encontram as reservas mais importantes da biosfera, continuam a alimentar o progresso dos países mais ricos à custa do seu presente e do seu futuro. A terra dos pobres do Sul é rica e pouco contaminada, mas o acesso à propriedade de bens e recursos para satisfazerem as suas carências vitais é-lhes vedado por um sistema de relações comerciais e de propriedade estruturalmente perverso (Papa Francisco 2015, 52-52).

Numa entrevista ao Papa Francisco, de janeiro de 20I4, o papa defende suas críticas ao sistema neoliberal ressaltando a necessidade urgente de operar mudanças estruturais.

Não podemos mais esperar para resolver as causas estruturais da pobreza, para curar as nossas sociedades de uma doença que só pode levar a novas crises. Os mercados e a especulação financeira não podem gozar de uma autonomia absoluta. Sem uma solução aos problemas dos pobres não resolveremos os problemas do mundo. São necessários programas, mecanismos e processos orientados a uma melhor distribuição dos recursos, à criação de trabalho, à promoção integral de quem está excluído. (Francisco apud Tornielli 20I5) 
Por estas ferrenhas críticas ao atual sistema econômico, Papa Francisco foi acusado pelos ambientes conservadores de ser comunista e próximo à Teologia da Libertação. Quando lhe perguntaram se tais acusações o perturbaram, Papa Bergoglio respondeu que a opção preferencial aos pobres está contida desde o início na mensagem evangélica.

Se eu repetisse alguns trechos das homilias dos primeiros Padres da Igreja, do segundo ou terceiro século, sobre como se deve tratar os pobres, haveria alguns que acusariam que a minha homilia é marxista. "Não é dos teus bens que tu doas ao pobre; tu só lhe devolves o que lhe pertence. Porque é àquilo que é dado em comum para o uso de todos que tu te apegas. A terra é dada a todos, e não somente aos ricos". São palavras de Santo Ambrósio, que serviram para que o Papa Paulo VI afirmasse, na Populorum progressio, que a propriedade privada não constitui para alguns um direito incondicional e absoluto, e que ninguém está autorizado a reservar para o seu uso exclusivo aquilo que supera a sua necessidade, quando aos outros falta o necessário. São João Crisóstomo afirmava: "Não compartilhar os próprios bens com os pobres significa roubá-los e privá-los da vida. Os bens que possuímos não são nossos, mas deles". (Francisco apud Tornielli 20I5)

A postura adotada pelo Papa Francisco, neste sentido, aparece revolucionária em relação à atitude tradicional da Igreja Católica e do papado. É verdade que também em documentos anteriores do Papa João Paulo II e Bento XVI podem ser encontradas críticas ao sistema econômico neoliberal. O próprio Papa Francisco as coloca em evidencia tanto na Exortação Apostólica Evangelii Gaudium quanto na Encíclica Laudato Sí. Contudo, tais críticas podem ser consideradas referências isoladas dentro de pontificados que não se destacaram por grandes mudanças e oposição ao sistema econômico vigente. Papa Francisco não perde ocasião para chamar atenção sobre as causas estruturais que geram pobreza, violência e desigualdade planetária. O apelo á mudança pode ser encontrado em todos os documentos e discursos pronunciados desde o início de seu pontificado.

\section{Conclusões}

Ao longo deste artigo, procuramos verificar a hipótese de que, nestes dois primeiros anos do pontificado, o Papa Francisco estaria realizando um deslocamento ideológico da Santa Sé, aproximando a estrutura central da Igreja Católica, tradicionalmente ligada às elites nacionais e internacionais, às periferias do mundo político e eclesial. 
Os passos dados por Francisco durante este período de dois anos e meio parecem contribuir à descentralização do poder até então restrito à Cúria Romana. Além disso, muitas decisões importantes tomadas pelo Papa Bergoglio, que por questões de limitação de espaço não foram tratadas neste trabalho, demonstraram uma tentativa de mudança de rumo por parte do Papa Francisco. Citamos por exemplo: a criação dos Encontros Mundiais dos Movimentos Sociais e o incentivo dado pelo Papa Francisco à luta deste setor da sociedade; a beatificação de Dom Oscar Romero, após anos de silêncio por parte da Santa Sé que o considerava próximo demais à esquerda de El Salvador; a reabilitação de padre Miguel d'Escoto, o sacerdote que se tornou, na década de I970, ministro das Relações Exteriores do governo sandinista e que por isso foi suspenso das suas funções sacerdotais por 29 anos; a mediação pontifícia entre Cuba e Estados Unidos, o reconhecimento formal do Estado da Palestina, entre os acontecimentos internacionais de maior relevo. De acordo com Cardini, Francisco

(...) como peronista tem uma visão social muito avançada, quase socialista. Para ele a ordem social é justiça social, solidariedade, amor e resgate dos últimos. Não é por acaso que Francisco condena sempre a economia, nunca diretamente a política. Ele quer que a sociedade retorne a um modelo de cristianismo puro, como o frei de Assis que se despojou de tudo. Só que na Idade Média o contexto era integralmente cristão. Bergoglio quer ao contrário derrubar a ordem constituída, reverter o rumo do progresso socioeconômico do turbocapitalismo. Aqui está sua revolução, o apocalipse (Cardini apud Ciolli 20I4).

\section{REFERÊNCIAS}

Ciolli, Barbara. 20I4. "Papa Francesco, La política estera del pontefice." Lettera43, August 22, 2014. Accessed October Io, 2014. http:// www.lettera43.it/politica/papa-francesco-la-politica-estera-delpontefice_43675138538.htm.

Dosdad Iranzo, Àngela. 2006. "Religión y Relaciones Internacionales Genealogías.” Foro Interno (6): 39-65.

Fox, Jonathan. 2006. "Religion et relations internationales: perceptions et réalités.” Politique Étrangère (4) (Hiver). http://www.cairn.info/revuepolitique-etrangere-2006-4-page-I059.htm

Ferrara, Pasquale. 20I4. Atlante teopolitico: religioni e relazioni internazionali. Roma: Città Nuova.

Francisco. 2013. Evangelii Gaudium: Exortação Apostólica sobre o anúncio do 
evangelho no mundo atual. Roma: Libreria Editrice Vaticana.

. Discurso aos Bispos Responsáveis do Conselho Episcopal Latino-Americano (C.E.L.A.M.), Rio de Janeiro, 28 de julho de 2013. Accessed May Io, 20I4. http://w2.vatican.va/content/francesco/pt/speeches/20I3/july/ documents/papa-francesco_20130728_gmg-celam-rio.html.

. Discurso no Encontro com os Cardeais e Colaboradores da Cúria Romana para a Troca de Bons Votos de Natal. Segunda-feira, 22 de Dezembro de 2014. Accessed April 20, 2015. http://w2.vatican.va/content/francesco/ pt/speeches/20I4/december/documents/papa-francesco_2OI4I222_ curia-romana.html.

. Encontro com todos os Funcionários do Estado da Cidade do Vaticano e respectivos Familiares. Sala Paulo VI, 22 de dezembro de 2014. Accessed April 20, 20I5. http://w2.vatican.va/content/francesco/pt/speeches/20I4/ december/documents/papa-francesco_20I4I222_dipendenti-santasede-scv.html.

. Laudato Sí: Encíclica sobre o cuidado da casa Comum, 24 de maio de 2015. Accessed May 30, 20I5. http://w2.vatican.va/content/francesco/pt/ encyclicals/documents/papa-francesco_20I50524_enciclica-laudato-si. html.

Frattini, Eric. 20I4. La CIA in Vaticano. Milão: Sperling \& Kupfer.

Haynes, Jeffrey. 2009. "Transnacional Religious Actors and International Order." Perspectives 17 (2): 43-70. Accessed July IO, 20I4. mercury.ethz. ch/.../Files/.../02_ogchapter3.pdf.

Politi, Marco. 20I4. Francesco tra i lupi: il segreto di una rivelazione. Roma-Bari: Editori Laterza.

Petito, Fabio, and Paulos Hazopoulos. 2003. Religion in International Relations: the return from exile. Palgrave MacMilian.

Parolin, Pietro. 2015. "Lectio Magistralis" del Cardinale Segretario di Stato al "Dies Academicus" della Pontificia Università Gregoriana. March 11, 2015. Accessed April 23, 2015. http://press.vatican.va/content/salastampa/ pt/bollettino/pubblico/20I5/03/II/oI78/00402.html

" "Lectio Magistralis" del Cardinale Segretario di Stato al "Dies Academicus" della Facoltà Teologica del Triveneto. April 4, 20I5. Accessed May Io, 20I5. http://www.fttr.it/fttr/allegati/I988/FTTR_20I5_04_24_ dies_academicus_prolusione_Parolin.pdf

Ratzinger, Jospeh. 2000. Presentazione del Motu Proprio Apostolos suos. July 27, 2000. Accessed July 23, 20I4. http://www.documentacatholicaomnia. eu/o4z/z_2000-07-27__Ratzinger._Joseph._Card__ 
Presentazione_'Apostolos_Suos'_IT.doc.html

Spadaro, Antonio. 2013. "Intervista a Papa Francesco." La Civiltà Cattolica. September I9, 2013. Accessed November I2, 20I4. https://w2.vatican. $\mathrm{va/content/francesco/it/speeches/20I3/september/documents/papa-}$ francesco_20I3092I_intervista-spadaro.html.

Tornielli, Andrea. 20I5. "Intervista a papa Francesco: Avere cura di chi è povero non è comunismo, è Vangelo". La Stampa. January II, 2015. Accessed February I4, 20I5. http://www.lastampa.it/20I5/OI/II/ italia/cronache/avere-cura-di-chi-povero-non-comunismo-vangelolasvmlIioCWdmIomYzig2J/pagina.html.

Turzi, Mariano. 20I3. "El Papa del tercer mundo." Foreign Affairs Latinoamérica I3 (3), I9-25. Accessed April 20, 20I4. www.fal.itam.mx.

\section{RESUMO}

Através de uma leitura internacional dos primeiros anos de pontificado de Francisco, associada à análise do contexto mundial e regional - com especial ênfase na conjuntura da América Latina - que o precedeu, buscar-se-á, nesta pesquisa, evidenciar a importância do papel que a Santa Sé pode desempenhar neste atual momento de reconfiguração mundial, não apenas em âmbito religioso, como também político. Tal estudo busca contribuir também para a construção de novas categorias conceituais aptas a explicar a noção de ator religioso transnacional e sua atuação no âmbito de um sistema internacional considerado pela maioria das teorias de relações internacionais como um sistema secularizado e com pouco espaço para o fenômeno religioso.

\section{PALAVRAS-CHAVE}

Santa Sé; Diplomacia; Ator Transnacional.

Recebido em 10 de julho de 2015. Aprovado em 2 de agosto de 2015. 


\section{ORDEN INTERNO Y POLÍTICA EXTERIOR ARGENTINA: LA CUESTIÓN DE LOS BIOCOMBUSTIBLES}

Cristian Lorenzo ${ }^{1}$

\section{Introducción}

Este trabajo contribuye a la comprensión de la política exterior argentina reciente, focalizando en el estudio de su orden interno. Para ello, se analiza cómo se fue configurando el apoyo político doméstico de la política exterior argentina hacia América Latina, en materia de biocombustibles.

El estudio de las interrelaciones entre el ámbito doméstico y las relaciones internacionales registra amplios antecedentes en Estados Unidos como en Europa (Gourevitch I978; Putnam i988; Duroselle i998). En América Latina, también se abordó este fenómeno tanto desde el punto de vista teórico como empírico. Hay un interesante aporte de van Klaveren, en este sentido, en el que realizó una clasificación de los enfoques teóricos generalmente utilizados. Si bien planteó que no había un consenso sobre cuál era la variable que más poder explicativo tenía, señaló que los comportamientos de política exterior, generalmente, eran considerados a partir de sus factores internos y externos (van Klaveren I984).

En Argentina, el fenómeno de la política exterior fue analizado, señalando una retroalimentación permanente entre el ámbito internacional y el interno. Por ejemplo, Figari señaló que: "si la política exterior de una nación está inserta en un contexto internacional determinado que influye sobre sus ámbitos culturales, políticos, sociales y económicos, no es menos cierto

\footnotetext{
I Licenciado en Relaciones Internacionales (Universidad del Salvador), magíster en Ciencia Política y Sociología (Flacso, Argentina) y doctor en Relaciones Internacionales (Universidad del Salvador). Es becario posdoctoral del Consejo Nacional de Investigaciones Científicas y Técnicas de Argentina (Conicet). Afiliación institucional: Centro Austral de Investigaciones Científicas (Cadic) - Conicet, situado en la ciudad de Ushuaia, Argentina. E-mail: clorenzo.ar@ gmail.com.
} 
que la política exterior, dentro de esos límites impuestos por el contexto internacional, también constituye la manifestación de los objetivos -valores e intereses- que la Nación pretende promover en el mundo" (Figari I993, 43). Cabe agregar que este autor distingue dos fases, una interna y otra externa, lo que permite ordenar los elementos principales de la cita referida. Dice: "toda política exterior tiene dos fases. Una es la faz interna que informa sobre los recursos que tiene la Nación, para promover sus valores e intereses en la faz externa" (Figari I993, 44).

Ana Seitz, por su parte, planteó que la política exterior "lejos de ser solo una política burocrática, es la resultante de un vector dinámico de fuerzas y presiones que se ejercen desde dentro de los países y desde el sistema internacional en su complejidad y que termina por ser sintetizada en las decisiones burocráticas aludidas" (Seitz 20I0, 2). Con esta definición, esta autora agregó la idea de "duraciones" de los fenómenos, en sintonía con el planteo de la escuela de los Anales.

Para este trabajo, interesan particularmente aquellas investigaciones que enfatizaron en el orden del interno como causas de la política exterior de Argentina. En este punto podría realizarse una distinción. Algunos, se focalizaron en la influencia de actores domésticos en la política exterior. Un ejemplo de ello, puede encontrarse en el trabajo de Roberto Miranda, quién analizó la formulación de políticas destinadas al Mercado Común del Sur (MERCOSUR) en el período I995-20II. Este autor concluye, en primer lugar, que la política doméstica no influenció relevantemente en la formulación de políticas en este ámbito de integración regional. En realidad, observó que los actores subestatales y no estatales de la vida política argentina no fueron incluídos en el proceso de toma de decisiones del Ejecutivo. Para Miranda, no había articulación entre el Ejecutivo y la Cancillería, por un lado; y actores subestatales y no estatales, por el otro. Esta desconexión descansaba, en definitiva, en una característica que permanece en el tiempo en Argentina: las decisiones externas están concentradas en el Ejecutivo (Miranda 200I).

También, hay trabajos que focalizan más en el contexto del orden interno y no sobre el comportamiento de actores, específicamente. A modo de ejemplo, Anabella Busso observó que en Argentina la política exterior es la política pública más cambiante desde la vuelta a su democracia. Su devenir no ha dependido tanto de variables sistémicas sino que ubica sus causas en el orden interno. Afirmó esta autora: "las principales causas que explican los vaivenes de la política exterior en democracia son las crisis político/económicas, las tensiones entre los distintos modelos de desarrollo y sus respectivas estrategias de inserción internacional y las variaciones en la concepción de democracia" (Busso 20I4). 
En el marco de estas interpretaciones, se sostiene que el apoyo político doméstico fue uno de los pilares de la política exterior argentina hacia América Latina en biocombustibles, durante los gobiernos de Néstor Kirchner (2003-2007) y Cristina Fernández (2007-20II). En función de esta afirmación, primeramente se presentan algunas características del contexto histórico del sector de la agroindustria en Argentina. Posteriormente, se aborda cómo fue posible obtener el apoyo político doméstico, a partir de la existencia de intereses en confrontación. Para ello, se analiza las posiciones de actores en el Congreso Nacional en la discusión sobre un proyecto presentado por el Senador Luis Falcó de la Unión Cívica Radical, que proponía promover el desarrollo de la producción de biocombustibles en Argentina. Luego, se analiza el posicionamiento del Instituto Nacional de Tecnología Industrial (INTI) y el Instituto Nacional de Tecnología Agropecuaria (INTA) en torno de la dimensión ambiental del modelo de desarrollo de biocombustibles de Argentina, su vinculación con otros actores y sus percepciones sobre las tendencias internacionales. Por último, se presenta la política exterior argentina en biocombustibles hacia América Latina.

\section{Exportaciones, política agropecuaria y ciencia}

En materia de comercio exterior, según datos de la Cámara Argentina de Biocombustibles, entidad que nuclea los intereses de las principales empresas exportadoras de este tipo de energía en Argentina, Argentina ha mantenido un crecimiento constante y significativo de sus exportaciones en biocombustibles, tal como se señala en la Tabla I. Si se compara el año 20II con el 2007, estas exportaciones crecieron en un rooo por ciento.

Tabla I - Exportaciones de Biodiesel de Argentina en toneladas

\begin{tabular}{|l|c|c|c|c|c|} 
& 2007 & 2008 & 2009 & 2010 & 2011 \\
\hline Totales & 168.364 & 724.792 & 1.149 .663 & 1363.506 & 1.692 .891 \\
\hline
\end{tabular}

Fuente: Cámara Argentina de Biocombustibles, 2014

Este es un sector, concentrado en empresas con capacidad de producción a grandes escalas, que recibió inversiones de empresas de origen nacional y extranjeras. En la tabla 2, se señalan la presencia de empresas internacionales en el sector: 


\begin{tabular}{|c|c|c|}
\hline Empresa & Grupo & $\begin{array}{l}\text { Capacidad de } \\
\text { Planta } \\
\text { (tn/año) } 2010\end{array}$ \\
\hline Renova S.A. & $\begin{array}{l}\text { Grupo Pérez Companc (Argentina), Grupo } \\
\text { Glencore (Suiza); Grupo Vicentín (Argentina) }\end{array}$ & 480.000 \\
\hline $\begin{array}{l}\text { LDC Argen- } \\
\text { tina S.A }\end{array}$ & Grupo Louis Dreyfus (Francia) & 240.000 \\
\hline Ecofuel & $\begin{array}{l}\text { Grupo AGD (Argentina); Bunge Limited (Esta- } \\
\text { dos Unidos) }\end{array}$ & 240.000 \\
\hline Cargill & Cargill (Estados Unidos) & 240.000 \\
\hline Explora & Grupo Meck (Chile) & 120.000 \\
\hline
\end{tabular}

Para situar en un contexto más amplio la tendencia de este sector de la economía, se toma como referencia el año 20ı, un año antes del final del período de estudio de este trabajo, para tener una visión global de cómo era la estructura de sus exportaciones de Argentina. Si se consideran las exportaciones por grandes rubros, las exportaciones de origen agropecuario $(33,3 \%)$ estaban levemente por debajo de las de origen industrial (35\%). Concentrándonos en el primer componente, el complejo más relevante fue el oleaginoso, con una participación estimada del 25\% (I3.963.732 de dólares) de las exportaciones totales argentinas (55.672.097 de dólares). Esto señala la importancia para la economía argentina y también, la existencia de una alta disponibilidad de aceite de soja, materia prima para producir biocombustibles en Argentina. Si dicho aceite se vendía directamente en el mercado internacional o se lo transformaba en biodiesel, dependía del precio internacional y de factores internos, como ser el cobro de derechos de exportación del estado argentino.

Asimismo, es necesario presentar dos aspectos adicionales: las exportaciones del sector oleaginoso provenían principalmente de la provincia de Santa Fe, ubicada en el sector litoral del país (Instituto Nacional de Estadísticas y Censos, 2010). A esta concentración geográfica de la producción se añadía que dichas exportaciones estaban concentradas en pocas empresas de una capacidad de producción a grandes escalas, tales como Cargill, Noble Grain, ADM y Bunge (Marín, Ana; Pérez Constanzó, Gloria. 20II, 20II, 22).

En política agropecuaria, las relaciones del gobierno con el campo transitaron coyunturas de una intensa conflictividad política. La introducción de retenciones a las exportaciones agropecuarias, mediante la Resolución I25/2008 durante el mes de marzo de 2008 representó una quita de las ga- 
nancias al sector rural, lo que produjo una serie de paros en distintos puntos del país. Esa medida estuvo vigente hasta el mes de julio, cuando finalmente se derogó. En el período transcurrido los sectores que representan intereses del sector agropecuario lideraron distintos paros y movilizaciones en el país. En el ámbito de los biocombustibles, la resolución I26/2008 incrementó el volúmen de retenciones a un $20 \%$. Aún hoy, este es un tema sensible para el sector porque afecta a sus ganancias.

Cabe añadir que en este contexto de confrontación entre el Gobierno nacional y las entidades representantes de intereses del sector agropecuario, la Secretaria de Ambiente y Desarrollo Sustentable arremetió contra los intereses del sector agropecuario. Publicó un informe concluyendo que: "La expansión de la soja representa una reciente y poderosa amenaza sobre la biodiversidad de Argentina ... La producción de sojas resistentes a los herbicidas conlleva también a problemas ambientales como la deforestación, la degradación de suelos, polución con severa concentración de tierras e ingresos, expulsión de la población rural a la frontera amazónica o áreas urbanas, fomentando la concentración de los pobres en las ciudades" (Secretaría de Ambiente y Desarrollo Sustentable, 2008).

Esto tuvo repercusiones en el ámbito científico. Durante el mes de abril de 2009 , las conclusiones a las que había arribado el Dr. Andrés Carrasco, investigador del Consejo Nacional de Investigaciones Científicas y Técnicas (CONICET), suscitó polémicas. Su crítica apuntaba a los efectos del glifosato a la salud humana. Esta iba en contra de los cimientos de un modelo agropecuario cuya productividad estaba influenciada por el uso de este herbicida. Esto dijo dicho investigador:

Se utilizaron embriones anfibios, un modelo tradicional de estudio, ideal para determinar concentraciones que pueden alterar mecanismos fisiológicos que produzcan perjuicio celular y/o trastornos durante el desarrollo. Y debido a la conservación de los mecanismos que regulan el desarrollo embrionario de los vertebrados, los resultados son totalmente comparables con lo que sucedería con el desarrollo del embrión humano (Página I2, I3 de abril de 2009).

Días más tarde, el Ministro de Ciencia y Tecnología argentino, el Dr. Lino Barañao, fue entrevistado por Héctor Huergo, un periodista con larga trayectoria en el ámbito rural y que estaba a favor del desarrollo de biocombustibles en Argentina. En el programa “El campo, la industria verde”, dijo: 
Tal vez habría que relativizar un poco estos resultados porque no son directamente extrapolables a lo que podría ocurrir en la situación de campo, es decir, que una sustancia puesta en contacto directo con un tejido puede tener efectos que no se verifican cuando esto se da en condiciones ambientales normales. Por otra parte, existe otra cantidad de estudios en el mismo sentido de exposición de células animales a distintas sustancias usadas que evidencian un efecto pero eso no es, repito, no es directamente extrapolable. Lo que sí creo es el aspecto positivo, es justamente recalcar que no hay sustancias inocuas, que hay que tener los recaudos necesarios para la manipulación de cualquier producto que se usa (La Política On Line, I de mayo de 2009).

Sus declaraciones, claramente, significaron un respaldo al rumbo que había tomado la política agroindustrial del gobierno argentino. Esto fue ratificado mediante un informe elaborado por un Consejo Científico Interdisciplinario creado en el ámbito del CONICET. No puede dejar de al menos mencionarse que los cuestionamientos al modelo dominante agrícola-exportador también venían de organizaciones no gubernamentales. Como contracara de este proceso del modelo agropecuario exportador, había actores domésticos críticos al modelo "sojero" de Argentina. El Grupo de Reflexión Rural era uno de ellos, quienes promovían la campaña "Paren de Fumigar". Como producto de los testimonios recolectados en distintos puntos del país, esta organización publicó en el 2009 el libro "Pueblos Fumigados. Los efectos de los plaguicidas en las regiones sojeras", denunciando las consecuencias sobre la salud humana del glifosato (Rulli 2009).

\section{Discusiones en el Congreso de la Nación}

En junio de 2004, el Senador Luis Falcó del partido Unión Cívica Radical presentó un proyecto de ley, con el nombre de "Régimen promocional para la investigación, desarrollo, generación y uso de los biocombutibles y derivados oleoquímicos". Esta no era la primera vez que en el Congreso de la Nación se presentaba un proyecto referido a biocombustibles, pero a diferencia de los anteriores, este proyecto prosperó y terminó convirtiéndose en ley. Cuando el Senador Falcó presentó su proyecto contó con el apoyo de 49 Senadores, pertenecientes a distintos partidos y provincias. Esto generó expectativas en altas esferas del poder. De hecho, el 3 de julio, el Vicepresidente de la Nación en ejercicio publicó un artículo en el diario Clarín destacando la importancia estratégica que esta política tenía. Esto permite calibrar la relevancia política de los biocombustibles. Su apoyo provenía del Vicepresidente 
de la Nación, miembro del partido político gobernante y opositor, quién afirmó: "Puede decirse que nos encontramos ante una iniciativa de envergadura estratégica, que cuenta con el consenso político suficiente como para colocar a la producción de biocombustibles en el lugar de una de esas grandes políticas de Estado que la Argentina necesita para forjar un porvenir venturoso para todos" (Scioli 2004).

El I de diciembre, el Senado dio media sanción al proyecto presentado por el Senador Falcó y giró este proyecto a 6 comisiones de Diputados. La última de las comisiones que presentó su dictamen fue la de Presupuesto y Hacienda, con modificaciones sobre sus aspectos fiscales e impositivos. Después de sancionarse el 22 de marzo de 2006 , este proyecto pasó nuevamente a Senadores, hasta que quedó sancionada como ley el ig de abril, con el nombre de "Régimen de regulación y promoción para la producción y uso sustentable de biocombustibles”. Finalmente, se reglamentó en febrero de 2007.

En esta sección, se analiza las posiciones de actores en el Congreso Nacional respecto de la posibilidad de regular la producción y consumo de biocombustibles en Argentina. El período de estudio se restringe al transcurrido desde que Falcó presentó el referido proyecto hasta su reglamentación. Y para ello, se aborda un dilema que transversalmente recorrió a las discusiones legislativas: ¿había o no que otorgar beneficios e incentivos al desarrollo de esta industria? Como parte de la puja de interés, el Secretario de Agricultura, en una publicación del diario Clarín en octubre de 2004, marcó claramente su posición, que afectaría directamente al surgimiento y despliegue del sector de los biocombustibles:

Probablemente, antes de fin de año contemos con la media sanción de un proyecto de ley de biocombustibles, para continuar su tratamiento legislativo el próximo año. Así, contaríamos con un proyecto de ley nacional, que prevea como mínimo la estabilidad fiscal a diez años para los futuros inversores en el sector, el corte obligatorio de gasoil y naftas con biodiesel y etanol al $5 \%$, la liberación en el IVA para los proyectos que califiquen ante la Autoridad de Aplicación, como instrumento fiscal imprescindible para suavizar el diferencial de precio actual entre los combustibles fósiles y los biocombustibles puros, y el fomento público al desarrollo de este nuevo sector (Campos 2004).

De la misma forma, otro actor clave en este proceso fue la Asociación Argentina de Biocombustibles e Hidrógeno (AABH). Desde esta organización se subrayó los beneficios tanto sociales, ambientales como económicos que se desprenderían de aquella industria que estaba en sus momentos ini- 
ciales de gestación. En este sentido, se destacó la importancia del componente fiscal e impositivo para su desarrollo:

Sin incentivos fiscales no es posible construir una oferta permanente de biocombustibles que se ajusten a un estándar de calidad óptimo. Por ello, a priori se plantea la cuestión del costo fiscal que dichos incentivos generan. Esta cuestión se torna relevante en países como Argentina, muy sensibles a la situación tributaria. Sin embargo, en cuanto se profundiza el análisis, surgen conclusiones sorprendentes (Molina 2004).

En el ámbito legislativo, dentro de los que estaban a favor de sancionar una ley para los biocombustibles encontramos que en el caso del Senador Urquía se dio la particularidad de además de pertenecer a un partido político oficialista con representación en el Congreso, era Presidente de una aceitera importante en Argentina. "Sin incentivos fiscales no es posible construir una oferta permanente de biocombustibles que se ajusten a un estándar de calidad óptimo" (Urquía 2005), afirmó contundentemente en una publicación realizada en el suplemento Rural del diario argentino Clarín. Este dato era fundamental porque manifiesta el interés del sector aceitero en posicionar a los biocombustibles como una alternativa energética en el país porque representaban una demanda adicional a sus productos. Un dato a tener en cuenta es que, una vez sancionada la ley de biocombustibles, puede observarse que la empresa que presidía -Aceite General Deheza- obtuvo de la Secretaría de Energía, una habilitación para comercializar su producción de biocombustibles en el mercado interno. Por más que su designación haya sido de acuerdo al procedimiento burocrático definido para tal motivo, dejaba poco claro dónde estaban los límites de la representación de intereses.

Frente a los aspectos fiscales e impositivos en cuestión, la Cámara Aceitera de la República Argentina (CIARA), envió una nota directamente a la Cámara de Diputados cuestionando el otorgamiento sin restricciones de beneficios fiscales e impositivos:

Finalmente cabe plantearse que si con todos los beneficios que el proyecto de ley establece ... los proyectos que se presenten no son viables económicamente, entendemos que entonces habría que repensar el tema con una evaluación más exhaustiva de los beneficios que se desprenderán de los mismos y eventualmente si se llegara a la conclusión de que es necesario un aporte adicional, éste debiera originarse en un desembolso en forma de subsidio explícito por la real diferencia que requiera la viabilidad del proyecto (Clarín 2005).

En esta puja por incluir o excluir beneficios fiscales e impositivos, se 
destrabó finalmente con el dictamen de la Comisión de Presupuesto y Hacienda del Congreso. Esta Comisión solicitó hacer una serie de cambios al proyecto para acotar el costo fiscal que traería para el país (Cronista.com 2006). En realidad, no solicitaba eliminarlos sino restringirlos. En un informe que la Asociación Federal de Ingresos Públicos envió a Diputados se expidieron de la siguiente forma:

Se estima inconveniente la implementación de este tipo de beneficios, entendiéndose mucho más apropiado el otorgamiento de subsidios directos a los sujetos que realicen las actividades que se intentan fomentar, siendo este último mecanismo más transparente y de mucho más fácil control, sin desvirtuar el régimen impositivo vigente (Clarín 2005).

Como resultado de las negociaciones, predominaron finalmente los intereses del Ministerio de Economía, por sobre aquellos que sí querían incluir en el proyecto, beneficios fiscales e impositivos. En este sentido, algunos legisladores del Senador manifestaron su oposición a las reformas de Diputados. Según el Senador Falcó, quien había presentado el proyecto originalmente, "desde el punto de vista de la forma le han cambiado hasta el título". Esto no era una cuestión cosmética, lo que reflejaba era una serie de cambios, producto de intereses en juego.

Nosotros hablábamos de un proyecto de investigación y de desarrollo de la industria de los biocombustibles y sus derivados; y la Cámara de Diputados lo tituló como un régimen de regulación y de promoción, que finalmente - a nuestro juicio - fue una seudo promoción de la industria de los biocombustibles. Esto habla un poco de la intencionalidad de los cambios estructurales del proyecto, ya que hasta su título fue cambiado sustancialmente (Cámara de Senadores de la Nación 2006, I3).

Este proyecto, finalmente, obtuvo sanción en Senado en abril de 2006 y fue reglamentado en febrero de 2007.

En resumen, lo desarrollado en esta sección manifiesta que la confrontación de intereses en el Congreso argentino estuvo en las diferentes concepciones sobre cómo desarrollar esta industria. En este sentido, una de ellas fue favorable a la implementación de beneficios fiscales e impositivos; y la otra apoyaba un proyecto sin beneficios fiscales e impositivos. En ambos casos, se afectaba directamente a la configuración de un mercado interno. Asimismo, lo analizado sugiere tener en cuenta que existieron casos de sobrerepresentación del sector aceitero. Hay que añadir que el proyecto con beneficios fiscales 
e impositivos perseguidos por la Asociación Argentina de Biocombustibles e Hidrógeno (AABH), junto al despacho del Senador Falcó (UCR-Río Negro) tuvo un rol significativo en su promoción hasta que confrontaron con los intereses del Ministerio de Economía para impulsarlos sin dichos incentivos.

\section{Disputas internas}

En febrero de 2007 se reglamentó una ley para regular el mercado interno de biocombustibles, según se refirió anteriormente. El rumbo que había tomando la política de este sector en Argentina generó disputas entre dos agencias descentralizadas del Estado argentino. Una de ellas fue el Instituto Nacional de Tecnología Industrial (INTI), que hoy se ubica en la órbita del Ministerio de Industria; y la otra, el Instituto Nacional de Tecnología Agropecuaria (INTA), organismo que depende del Ministerio de Agricultura, Ganadería y Pesca de la Nación.

En esta sección, se analiza el posicionamiento de ambas instituciones respecto de la dimensión ambiental de este modelo de desarrollo, su vinculación con otros actores y sus percepciones sobre las tendencias internacionales. Para la primera institución, se analiza la posición de su Presidente respecto de estos asuntos, Enrique Martínez. Y para la segunda, al referente del Programa Nacional de Bioenergía del INTA, Jorge Hilbert. Éstos fueron seleccionados por haber participado en este proceso de discusiones en el orden interno y en la construcción de esta alternativa energética. A tal efecto, se utilizaron documentos de posicionamiento institucional, publicados en el contexto de la discusión del orden interno respecto de los biocombustibles.

Desde el INTI, se cuestionó el modelo de desarrollo en biocombustibles. Su Presidente planteó que el balance ambiental de los biocombustibles (biodiesel y etanol) era negativo. Esta consideración no menor, le permitía plantear y abrir un debate más amplio orientado a involucrar a otras opciones energéticas alternativas. En un documento publicado en 2007 se manifestó a favor de descentralizar la producción y consumo de este tipo de energía a nivel interno:

No tiene igual promoción mediática ni en muchos casos institucional, por descentralizar las fuentes de energía, la producción de biodiesel para usarlo al ıо०\%, a escala de una chacra. Hay ya un amplio damero de opciones de generación y consumo descentralizados, que harían menos necesarios los sistemas de producción y distribución de alta concentración, como los actuales (Martínez 2007a). 
Estas ideas sobre el desarrollo de biocombustibles ubicaron al INTI en confrontación con otros actores del ámbito público y privados del orden doméstico. En el primer caso, se diferencia claramente de la posición adoptada por el INTA.

Si la ecuación energética no cierra a partir del etanol o cuando se hace a partir del maíz no hay que ser necios. Ahí no hay un negocio solamente. Si no hay generación neta de energía, es todo un negocio absurdo, pero además de eso tampoco hay que comprar alegremente alternativas como la que dolorosamente, cuando nos embarcamos en el análisis de alternativas para agrocombustibles, elige el INTA. Yo tengo mucho respeto por la gente del INTA y he participado de muchos paneles. Creo que hay gente muy seria, que ha estudiado mucho el tema, pero se ve obligada por su exposición ante los hombres de negocios del campo a inventar alternativas como la de la jatrofa (Martínez 2007b).

También, criticó a la Asociación Argentina de Biocombustibles e Hidrógeno $(\mathrm{AABH})$, entidad que fomentó el desarrollo de los biocombustibles en Argentina y que participó durante el proceso de sanción de la ley de biocombustibles.

Un organismo como el nuestro tendrá que buscar mejorar el caudal tecnológico de la sociedad en los temas que crea más convenientes, pero deberíamos detenernos un minuto a tener la mirada global, porque si nos quedamos en la mirada específica nos va a pasar lo que le pasa a Claudio Molina, que viaja al exterior y vuelve espantado porque el biodiesel es más barato que el aceite de soja. ¡Pobre Claudio! (Martínez 2007c).

Pasado al plano internacional, Enrique Martínez realizó una lectura crítica de la industria global de biocombustibles. Señaló que los productores agrícolas al garantizarse una nueva demanda mundial fueron los principales beneficiados, como ocurrió, por ejemplo, en Estados Unidos; y quienes necesitaron importar maíz para consumo humano fueron los perjudicados porque a nivel internacional, el maíz tenía un nuevo destino: su conversión energética. Desde su diagnóstico, esta situación del comercio internacional del mercado alimentario y energético, ocasionaba dos consecuencias concretas: I-aumento de precios de los alimentos; 2-la posibilidad que Estados Unidos se posicione como comprador dominante en toda la cadena del mercado mundial de etanol (Martínez 2007b). También, situó a esta cuestión en el marco de una problemática ambiental global, asociándolo directamente a los patrones de consumo de los más ricos. Y por último, lo conectó a otros aspectos que 
instalan desafíos como una mayor demanda de tierra para sostener una creciente producción de alimentos ante proyecciones de crecimiento poblacional (Martínez 2007c).

Desde el INTA el involucramiento en torno del desarrollo de energías alternativas no constituyó un fenómeno novedoso. Su desarrollo en el tiempo fue interrumpido por un conjunto de variables, algunas de mercado y otras socio-ambientales. Desde su concepción, incluían un abanico de alternativas energética, entre las cuales se encontraba el biodiesel (Entrevista a Jorge Hilbert, 7 de julio de 2008).

En marzo de 2008, el INTA publicó un documento institucional. A diferencia del INTI, no se cuestionó la dimensión ambiental del modelo de desarrollo en biocombustibles. En su lugar, desde el supuesto de la "abundancia” de recursos naturales del país, tomaron con preocupación el cuidado de ciertos aspectos ligados a balances energéticos, la conservación de la biodiversidad, así como también, el impacto sobre el agua y el suelo. Esta "agenda ambiental”, ¿en función de qué era importante? Este es un interrogante central para comprender la forma de concebir que esta institución tenía sobre este asunto. Este proyecto no estaba orientado a desarrollar un proceso de descentralización de la producción y consumo de los biocombustibles. En su lugar, la preocupación estaba puesta en mejorar la oferta exportadora del país:

Argentina posee las condiciones necesarias para generar parte de la biomasa que se requerirá a nivel mundial" es una frase elocuente, en este sentido... La producción actual de granos, aceites y proteína vegetal, ubica a nuestro país como uno de los líderes mundiales en su exportación. El aprovechamiento de esos recursos para su conversión en bioenergía así como otros productos como harinas proteicas, vegetales y animales generará la oportunidad de, exportar mayor valor agregado en un plazo casi inmediato. Al mejorar la oferta exportadora del país, se podrán ofrecer alternativas de mercado para propiciar un mayor nivel de actividad, con el propósito de incrementar competitividad, productividad, sostenibilidad y equidad en la producción agropecuaria (Instituto Nacional de Tecnología Agropecuaria 2008, 3-4).

Esta "vocación exportadora" de Argentina, por su disponibilidad en abundantes recursos naturales, proyectaba transformaciones en el uso y la finalidad de su producción. Desde esta concepción, la agricultura no solo producía solamente alimentos sino también, energía. Además, la silvicultura también se posicionaba como una fuente de materias primas para producir energía a través de los residuos forestales. Como esto generaría cambios en el orden interno, desde el INTA proyectaban planificar el uso del suelo. En este 
sentido, uno de sus objetivos era definir un mapa nacional para distinguir tipos de suelos disponibles y zonas agroecológicas. Incluso, consideraban necesario introducir una Evaluación de Impacto Ambiental (EIA), que asegurara que realmente estaba trayendo beneficios ambientales.

En su vinculación con otros actores, su estrategia fue bifronte. Por un lado, buscaba tener aliados estratégicos en el ámbito estatal para la elaboración de una estrategia de desarrollo. Su enfoque articulaba energía, alimentos y medio ambiente. Para el INTA, "la política de fomento para la generación de biocombustibles, a partir de materias primas agrícolas y forestales nacionales, deberá ser tomadas como un Proyecto-País en su conjunto, el cual se complementará con la estrategia de seguridad alimentaria (disponibilidad de alimentos) y la de convertir a Argentina en un relevante actor agroindustrial/ alimentario. Como un principio básico de este enfoque, se destaca la necesidad de que el uso de los recursos naturales, suelo y agua para la producción de bioenergía, no debería afectar su disponibilidad, ni entrar en competencia con la producción de alimentos para el consumo interno y de exportación" (Instituto Nacional de Tecnología Agropecuaria 2008, 5).

Otra estrategia consistió en fomentar acciones de cooperación internacional. En este documento se presentan algunos ejes fundamentales de desarrollo del Programa Nacional de Bioenergía. Hay uno de ellos que está definido como "investigación y desarrollo". Se informa que las actividades de esta institución estarán orientadas a desarrollar tecnología para lograr tener un aprovechamiento integral de la biomasa. En ese marco, aparece una vinculación institucional con Naciones Unidas, específicamente con una de sus agencias: la Organización de las Naciones Unidas para la Agricultura y la Alimentación (FAO). A pesar que no hay una mención explícita de sus vinculaciones internacionales, aquí se conecta con la dinámica de la política internacional. En este sentido, uno de los proyectos fue llamado "Mapeo de Oferta y Demanda Integrada de Dendrocombustibles", conocidos por su siglas en inglés "WISDOM", que significa "Woodfuel Integrated Supply/Demand Overview Mapping”. En este marco, se generó un documento con el objetivo de tener información disponible sobre cuánto y dónde se disponía de biomasa en Argentina. (Organización de las Naciones Unidas para la Agricultura y la Alimentación 2009).

Respecto de sus percepciones sobre las tendencias internacionales, algo de esto se adelantó cuando se abordó cómo concebían la dimensión ambiental sobre el modelo de desarrollo. En el documento en cuestión, está presente la idea de un cambio de paradigma energético que países industrializados estaban transitando, pasando de economías "fosilizadas" a otras "verdes". En el documento se señala que: "La bioenergía está llamada a cumplir un 
rol junto a otras fuentes no convencionales en el cambio, de una economía basada en los combustibles fósiles a otra basada en un abanico de fuentes. La agricultura y la silvicultura serán las principales fuentes de biomasa para elaborar bioenergía en diferentes vectores, como la leña, el carbón, briquetas, biogás, bioetanol, biodiesel y bioelectricidad, entre otros" (Instituto Nacional de Tecnología Agropecuaria 2008, 2). Nótese que desde esta concepción no se está haciendo referencia exclusivamente al biodiesel o el etanol. Lo que plantean es más amplio en términos de opciones energéticas. En esta descarbonización de la economía, la biomasa adquiere una importancia central al ensanchar las posibilidades de materias primas utilizables para la generación de energía. En definitiva, esto representaba generar transformaciones en el uso en la finalidad de los recursos naturales en Argentina.

Esta sección, en resumen, se analizó el posicionamiento del INTI e INTA mediante tres ejes de análisis: la dimensión ambiental en la industria de biocombustibles, su vinculación con otros actores y sus percepciones sobre las tendencias internacionales. Se destaca que estos actores mantuvieron formas antagónicas de posicionamiento. De ellas, la visión del INTA fue la que terminó proyectándose en la política exterior de Argentina hacia América Latina en biocombustibles. En este sentido, se avanzó en menor medida en el fomento de experiencias de cooperación para incentivar la producción y consumo de este tipo de energía en forma descentralizada y en pequeñas escalas.

\section{América Latina}

Casi en paralelo a estas discusiones, en diciembre de 2006, el Consejo del Mercado Común decidió aprobar un Memorandum de Entendimiento para crear un Grupo Ah Hoc en Biocombustibles y recomendó su firma entre las partes. Su objetivo era estimular tanto la producción como consumo de biocombustibles; dentro de sus intereses estaba fomentar la cooperación técnica entre las partes. La I reunión tuvo lugar en marzo de 2008. Entre las cuestiones que se decidieron se destaca el acuerdo para realizar un taller sobre aspectos técnicos referidos a las cualidades físico-químicas de los biocombustibles, así como también mapear las empresas que hacían investigación en cualquiera de los eslabones de la cadena de producción de biocombustibles en el MERCOSUR. Éste fue el comienzo de este espacio de integración regional.

Meses más tarde, el MERCOSUR comunicó su posición institucional frente a la polémica internacional relación entre alimentos y biocombustibles. Aquí, los Presidentes del MERCOSUR disociaron la conexión entre 
producción de biocombustibles e incremento del precio de los alimentos, así como también, se posicionaron antagónicamente a países desarrollados que utilizaban materia prima agrícola para producir energía. Al mismo tiempo, ratificaron el rumbo que la política regional estaba tomado: la energía era considerado como un recurso estratégico para el MERCOSUR. Esto quedó claro en el punto 36 del Comunicado, en la que: "reconocieron asimismo la importancia de promover el uso y la producción de biocombustibles como fuente de energía renovable y alternativa capaz de contribuir a la diversificación de la matriz energética regional. Asimismo, registraron con satisfacción los avances alcanzados en el ámbito del Grupo Ad Hoc sobre Biocombustibles (GAHB) y destacaron la importancia de la implementación del Plan de Acción del MERCOSUR para la Cooperación en Materia de Biocombustibles" (MERCOSUR 2008).

Retomando los avances del Grupo Ah Hoc en Biocombustibles, al final del período que se estudia, se produjo su V reunión en 20I0. De acuerdo a lo que se observa del Acta final, la sustentabilidad de los biocombustibles constituyó un asunto de preocupación para los estados miembros. En este sentido, como línea de acción futura definieron que deberían establecer conjuntamente un criterio de sustentabilidad ambiental para respaldar su producción. Asimismo, aparecieron dos cuestiones con un claro componente político. Decidieron que deberían establecer posiciones conjuntas antes de participar en foros internacionales, así como también, definieron que era necesario participar activamente en la Asociación Internacional de Bioenergía, una asociación compuesta por actores públicos y privados de diferentes partes del mundo.

Otro espacio en el ámbito de la integración regional es el Consejo Agropecuario del Sur (CAS), compuesto por Argentina, Bolivia, Brasil, Chile, Paraguay y Uruguay, con el objetivo de coordinar políticas públicas agropecuarias. Uno de sus Grupos de Trabajo era, precisamente, el de Bioenergía. El soporte técnico y operativo de sus actividades estuvo a cargo del Instituto Interamericano en Cooperación para la Agricultura (IICA) y la Secretaría del CAS. En la VIII Reunión Ordinaria, que tuvo lugar en noviembre de 2005, se insistió en que su creación debería ser a la brevedad y que debería estar coordinado por Brasil (Consejo Agropecuario del Sur 2005). Posteriormente, en diciembre de 2007 , se decidió que se trabajaría en forma complementaria con el Grupo Ad Hoc en Biocombustibles del MERCOSUR (Consejo Agropecuario del Sur 2007). En marzo de 2008, en el contexto de la suba de precios de los alimentos en el mercado internacional, la CAS emitió un comunicado ratificando el rumbo de la política regional. Consideraban que los países integrantes del CAS tenían disponibilidad suficiente de materia prima 
como para producir alimentos y energía. A diferencia del grupo especializado del MERCOSUR, su mensaje incluyó una mención especial a la agricultura familiar. Esta referencia es relevante porque manifiesta un proyecto diferente al del MERCOSUR, en el que la escala de producción sería mucho menor: el sujeto beneficiario serían cooperativas de pequeños productores (Consejo Agropecuario del Sur 2008).

En otro orden, Venezuela y Cuba mantuvieron una posición crítica frente a la firma del acuerdo de cooperación entre Estados Unidos y Brasil para impulsar el desarrollo de la producción de biocombustibles en el continente americano, principalmente en América Central. En este contexto, se realizó la Cumbre Energética Sudamericana en Venezuela. Fue realizado en abril de 2007, en el marco de la Comunidad Suramericana de Naciones. Aquí, se produjeron hechos de vital importancia para la integración latinoamericana. La Comunidad Suramericana de Naciones pasó a llamarse Unión de Naciones Suramericanas y también, se creó el Consejo Energético de Suramérica. En materia de biocombustibles, el conflicto regional se saldó y se orientó hacia el desarrollo de este tipo de energía: "impulsar el desarrollo de las energías renovables, ya que cumplen un papel importante en la diversificación de la matriz energética primera, la seguridad energética, la promoción del acceso universal a la energía y la preservación del medio ambiente" (Comunidad Suramericana de Naciones 2007).

Tres años más tarde, se registraron avances. En la Cumbre extraordinaria de 20 Io en Los Cardales (Argentina), el Consejo Energético Suramericano aprobó una serie de documentos, producto de las reuniones que mantuvieron desde su creación como Consejo. Lo importante aquí es la elaboración de los lineamientos de la Estrategia Energética Suramericana y del Plan de Acción para la Integración Energética Regional, así como también, el establecimiento de la estructura del Tratado Energético Suramericana (Unión Suramericana de Naciones; Organización Latinoamericana de Energía 20I2, I5-16). En términos concretos, algunos de los criterios rectores que fueron definidos regionalmente fueron: asegurar el abastecimiento energético en la región; promover el intercambio energético regional; fortalecer la infraestructura energética regional; incentivar las acciones de cooperación entre empresas estatales de hidrocarburos; propiciar el intercambio y transferencia de tecnologías; y planificar regionalmente el uso de la energía. En este marco, definieron un plan de acción por cada tipo de energía, junto a un detallado número de actividades. En lo que se refiere a energías renovables, hay una referencia específica a los biocombustibles, en la que tienen como objetivo promover el uso y la producción de biocombustibles para diversificar la matriz energética regional (Unión Suramericana de Naciones; Organización Latinoamericana de Energía 20I2, I5-30). 


\section{Conclusiones}

En el marco de los estudios sobre política exterior, este trabajo se concentró en la política exterior reciente de Argentina y particularmente, en las relaciones entre orden interno y política exterior. Más concretamente, se analizó cómo fue posible la construcción del apoyo político doméstico de la política exterior de Argentina hacia América Latina en biocombustibles.

Como estrategia de abordaje, se seleccionaron dos ámbitos diferenciados y relevantes que sirvieron como fundamentos de la política exterior argentina, uno el legislativo nacional y el otro, el científico-técnico. En el primero, se analizaron las posiciones de actores en el marco de discusiones legislativas sobre un proyecto de Ley que terminó siendo, modificaciones mediante, la ley que actualmente regula en Argentina la producción y consumo en el mercado interno de biocombustibles. En el segundo, se avanzó sobre la polémica entre dos agencias especializadas del estado argentino: el INTA y el INTI. Por último, se analizó la política exterior de Argentina hacia América Latina. Se concluye, a partir de lo analizado y desarrollado en cada una de las secciones, que el apoyo político doméstico fue uno de los pilares de la política exterior argentina hacia América Latina en biocombustibles, durante los gobiernos de Néstor Kirchner (2003-2007) y Cristina Fernández (2007-20II).

Los alcances de estas conclusiones permiten corroborar algunos aspectos del diagnóstico realizado por otros autores, que investigaron el mismo tema y al mismo tiempo, permiten señalar nuevos aspectos. De acuerdo a lo observado por Miranda, en la toma de decisiones en Argentina, las decisiones en política exterior permanecieron concentradas en el Ejecutivo, es decir, la Cancillería y el Ejecutivo no abrieron el juego a que otros actores estatales y no estatales participaran durante el proceso. En este sentido, la política exterior de Argentina hacia América Latina en biocombustibles puso en manifiesto esta dinámica. Por último, es necesario agregar que si bien la investigación realizada no se concentró en los cambios o ajustes en política exterior y en su interrelación con los factores domésticos como lo hizo Busso, lo que sí si sugiere este trabajo es la existencia de fundamentos internos de la política exterior que permite trazar continuidades entre el orden interno y los lineamientos de la política exterior argentina hacia la América Latina, en materia de biocombustibles. 


\section{REFERÊNCIAS}

Busso, Anabella. 20I4. "Los vaivenes de la política exterior argentina redemocratizada (1983-2013). Reflexiones sobre el impacto de los condicionantes internos." Estudios Internacionales I77: 9-33.

Cámara de Senadores de la Nación. 2006. "Versión Taquigráfica - Sesión Ordinaria, I9 de abril de 2006 ", ig de abril. Acceso io de noviembre. http://www.senado.gov.ar/parlamentario/sesiones/busqueda

Campos, Miguel. 2oro. "La llegada definitiva de las energías limpias." Clarín, 30 de octubre. Acceso Io de noviembre, 20I4. http://edant.clarin.com/ suplementos/rural/2004/10/30/r-oiıio.htm

Clarín. 2005. "Con el tanque aún vacío." Clarín, 7 mayo. Acceso ro de noviembre, 20I4. http://edant.clarin.com/suplementos/ rural/2005/05/07/r-0020I.htm

Consejo Agropecuario del Sur. 2005. "Declaración de Ministros. VIII Reunión Ordinaria de Ministros.", is de noviembre. Acceso io de noviembre. http://www.consejocas.org/index.php/cas/reuniones-decas/reuniones-ordinarias

2007. "Declaración de Ministros. XIII Reunión Ordinaria de Ministros."

3 de diciembre. Acceso io de noviembre. http://www.consejocas.org/ index.php/cas/reuniones-de-cas/reuniones-ordinarias

_ 2008. "Contribuciones para una política agrícola regional en agroenergía, Grupo sobre Políticas Públicas en Agroenergía (GT6) - Red de Coordinación de Políticas Agropecuarias." http://agris.fao.org/agrissearch/search.do?recordID=AR2008000234

Comunidad Suramericana de Naciones. 2007. "Declaración de Margarita. Construyendo la integración energética del sur", abril. Acceso io de noviembre. http://unasur.webcindario.com/documentos.html

Cronista.com. 2006. "Cuatro leyes económicas son ahora prioridad en Diputados." Cronista, 26 de febrero. Acceso ro de noviembre. http:// www.cronista.com/impresageneral/Cuatro-leyes-economicas-sonahora-prioridad-en-Diputados-20060227-0033.html

Duroselle, Jean-Baptiste. I988. Todo imperio perecerá. Teoría sobre las relaciones internacionales. México: Fondo de Cultura Económica.

Figari, Guillermo. I993. Pasado, presente y futuro de la política exterior argentina. Buenos Aires: Editorial Biblos.

Gourevitch, Peter. I978. "The Second Image Reversed: The International Sources of Domestic Politics.”. International Organization 32 (4): 88I- 
892.

Instituto de Tecnología Agropecuaria. 2008. Programa Nacional de Bioenergía: Posicionamiento Institucional.

Instituto Nacional de Estadísticas y Censos. 20II. "Comercio exterior argentino 2010.” Acceso Io de noviembre. http://www.indec.mecon. ar/nuevaweb/cuadros/i9/com_ext_anu_io.pdf

La Política On Line. 2009. "Barañao desmiente estudio contra el glifosato: No es del Conicet.", I de mayo. Acceso Io de noviembre, 20I4. http://www. lapoliticaonline.com/nota/35858/

Martínez, Enrique. 2007a. "ENERGÍA + MEDIO AMBIENTE + ALIMENTOS: un humilde llamado de atención”, I7 enero. Acceso ro de noviembre, 20I4. http://www.inti.gov.ar/pdf/energia_medioambiente_alimentos. pdf

_ 2007b. "Etanol. ¿Oportunidad de qué?” Abril. Acceso ro de noviembre, 2014. http://www.inti.gov.ar/sabercomo/sc5I/intir.php

_ 2007c. "Reflexiones y Perspectivas sobre el papel de los Agrocombustibles en la Argentina", 5 de diciembre. Acceso ro de noviembre, 20I4. http:// www.iade.org.ar/modules/noticias/article.php?storyid=225I

Mercosur. 2008. "Comunicado conjunto de los Presidentes del MERCOSUR. XXXV Reunión del Consejo del Mercado Común”, i de julio. Acceso io de noviembre. https://mrecic.gov.ar/node/33045

Marín, Ana; Pérez Constanzó, Gloria. 20ıı. "Complejo Oleaginoso, Ministerio de Economía de Argentina. Subsecretaría de Programación Económica.” Acceso ro de noviembre http://www.mecon.gov.ar/peconomica/docs/ Complejo_Oleaginoso.pdf

Miranda, Roberto. 200I. "El eje doméstico de las cuestiones externas de la Argentina: el caso del Mercosur.” Invenio 4, (7): 99-156.

Molina, Claudio. 2004. "Energía limpia, empleo y desarrollo." Clarín, 4 de diciembre. http://edant.clarin.com/suplementos/ rural/2004/12/04/r-0040I.htm

Organización de las Naciones Unidas para la Agricultura y la Alimentación. 2009. "Análisis del Balance de Energía derivada de Biomasa en Argentina. Informe Final.” Acceso ro de noviembre. http://64.76.I23.202/ probiomasa/_pdf/Balance_de_Energia.pdf

Página 12. 2009. "El tóxico de los campos." Página 12, I3 de abril. Acceso Io de noviembre, 20I4. http://www.paginas2.com.ar/diario/ elpais/I-I23III-2009-04-I3.html

Putnam, Robert. I988. "Diplomacy and Domestic Politics: The Logic of Two- 
Level Games." International Organization 42: 427-460.

Rulli, Jorge. 2009. Pueblos Fumigados. Los efectos de los plaguicidas en las regiones sojeras. Buenos Aires: Editorial del Nuevo Extremo.

Scioli, Daniel. 2004. "Una política de biocombustibles." Clarín, 3 de julio. http://edant.clarin.com/suplementos/rural/2004/07/03/r-0200I.htm

Secretaría de Ambiente y Desarrollo Sustentable. 2008. "El avance de la frontera agropecuaria y sus consecuencias". Acceso io de noviembre. http://www.grr.org.ar/sym/avance_soja.pdf

Seitz, Ana. 2oro. "Integración Latinoamericana-Caminos, dilemas y desafíos." Ponencia presentada a la Jornada de la Red de Integración Latinoamericana (REDILA), Mendoza.

Unión de Naciones Suramericanas; Organización Latinoamericana de Energía. 20I2. "UNASUR: un espacio que Consolida la Integración Energética." Acceso to de noviembre. http://www.olade.org/es/ publicaciones/unasur-espacio-que-consolida-la-integracion

Urquía, Rubén. 2005. "Biocombustibles, una exigencia." Clarín, i9 de noviembre. Acceso to de noviembre. http://edant.clarin.com/ suplementos/rural/2005/II/I9/r-0280I.htm

van Klaveren, Alberto. I984. "El análisis de la política exterior latinoamericana: perspectivas teóricas." En Entre la autonomía y la subordinación. Política exterior de los países latinoamericanos, editado por Muñoz, Heraldo; Tulchin, Joseph. Buenos Aires: Editorial GEL.

\section{RESUMO}

El apoyo político doméstico fue uno de los pilares de la política exterior argentina en biocombustibles hacia América Latina, durante los gobiernos de Néstor Kirchner (2003-2007) y Cristina Fernández (2007-2011).

\section{PALAVRAS-CHAVE}

Política Exterior; Biocombustibles; Medio Ambiente.

Recebido em 6 de setembro de 2013. Aprovado em 13 de abril de 2015. 


\section{PARCEIROS}

\section{NERINT}

O Núcleo Brasileiro de Estratégia e Relações Internacionais (NERINT) foi o primeiro centro voltado exclusivamente ao estudo e à pesquisa em Relações Internacionais no sul do Brasil. Foi estabelecido em I999 junto ao ILEA-UFRGS visando ao estudo crítico e inovador das principais transformações do sistema internacional pós-Guerra Fria. Desde 20I4, o NERINT está localizado na Faculdade de Economia da UFRGS (FCE - UFRGS). Paralelamente, buscou contribuir para a retomada da discussão de um projeto nacional para o Brasil através da análise das opções estratégicas disponíveis para a consolidação da inserção internacional autônoma do país, a partir da perspectiva do mundo em desenvolvimento. $\mathrm{O}$ advento de uma "diplomacia ativa, afirmativa e propositiva” no Brasil no início do século XXI veio a convergir com as análises e projeções feitas nos seminários e publicações do NERINT.

Um dos resultados de sua atividade foi a implantação de um curso de graduação em Relações Internacionais (2004), o melhor do país de acordo com o Ministério da Educação (20I2), e de um Programa de Pós-Graduação em Estudos Estratégicos Internacionais (2010). Duas revistas também foram criadas: a bimestral Conjuntura Austral e a semestral e bilíngue Austral: Revista Brasileira de Estratégia e Relações Internacionais. Assim, além da pesquisa avançada, focada prioritariamente nos países emergentes, o NERINT deu origem a programas de graduação e pós-graduação, além de propiciar intensa atividade editorial.

\section{PPGEEI}

O Programa de Pós-Graduação em Estudos Estratégicos Internacionais (PPGEEI) iniciou suas atividades em 2010, com cursos de Mestrado e Doutorado, ambos propiciados por qualificados professores e pesquisadores com experiência internacional. Ele é resultado dos avanços obtidos nas áreas de pesquisa e ensino (Graduação e Pós-Graduação) na Universidade Federal do Rio Grande do Sul (UFRGS).

Suas raízes estão no Núcleo Brasileiro de Estratégia e Relações Internacionais (NERINT), um centro criado em i999 que realiza pesquisas, seminários e edita dois periódicos. Conta também com o apoio do Núcleo de Estudos em Tecnologia, Indústria e Trabalho (NETIT/FCE) e do Centro de Estudos Internacionais sobre Governo (CEGOV), sediado no Instituto Latino 
Americano de Estudos Avançados (ILEA/UFRGS). Em 2004, foi iniciado um curso de Graduação em Relações Internacionais na FCE/UFRGS, em 2005 foi formado o Centro de Estudos Brasil-África do Sul (CESUL) e, em 20I2, este transformou-se no Centro Brasileiro de Estudos Africanos (CEBRAFRICA). Tudo isto permitiu a formação de uma massa crítica, apoiada em ampla biblioteca especializada.

A tradição de pesquisa que deu origem ao PPGEEI baseou-se numa análise prospectiva das tendências mundiais dos anos I990. A notável expansão da diplomacia e da economia brasileiras a partir do início do século XXI confirmou a perspectiva adotada, que permitiu a intensa cooperação com os organismos diplomáticos e econômicos internacionais do Brasil. O curso já é uma referência na análise estratégica da inserção das potências emergentes e das relações internacionais Sul-Sul.

A visão diferenciada do PPGEEI dá ênfase a métodos estratégicos, teóricos e aplicados, sempre baseados em rígidos princípios acadêmicos e científicos. Por esta razão, tem sido procurado por estudantes de todo o Brasil e de vários países, e tem estabelecido parcerias em todos os continentes. Por essas razões, é um programa focado na compreensão das rápidas transformações pela qual passa o sistema internacional. Publica em parceria com o NERINT as revistas Conjuntura Austral (bimestral) e Austral: Revista Brasileira de Estratégia e Relações Internacionais (semestral e bilíngue). O PPGEEI possui três linhas de pesquisa:

\section{Economia Política Internacional}

Enfoca a inserção internacional da economia brasileira e de outros grandes países em desenvolvimento na América do Sul, na Ásia e na África; aborda as características e os efeitos da globalização; e desenvolve estudos comparados e setoriais preocupados com os efeitos da internacionalização de empresas e segmentos produtivos. Especial atenção é dada às crises financeiras internacionais e seus reflexos no Brasil e nos demais países do Sul.

\section{Política Internacional}

Enfatiza a análise do processo de formação, implementação e avaliação de política externa. Procura confrontar padrões de inserção internacional de países estratégicos de América do Sul, África e Ásia, considerando padrões institucionais, política comercial, estruturas de intermediação de interesses e atuação de atores da sociedade civil no eixo Sul-Sul das relações internacionais contemporâneas. 


\section{Segurança Internacional}

Aborda os principais problemas de segurança no sistema internacional a partir de uma perspectiva que leva em conta os Estados mais poderosos no nível global, mas que introduz de maneira sistemática o problema das balanças regionais de poder, o eixo Sul-Sul, a existência de complexos regionais de segurança e o impacto das tecnologias de informação na Era Digital.

\section{CEBRAFRICA}

O Centro Brasileiro de Estudos Africanos (CEBRAFRICA) tem suas origens no Centro de Estudos Brasil-África do Sul (CESUL), um programa estabelecido em 2005 através de um convênio entre a Universidade Federal do Rio Grande do Sul (UFRGS) e a Fundação Alexandre de Gusmão (FUNAG), do Ministério das Relações Exteriores do Brasil. Suas atividades de pesquisa são desenvolvidas junto ao Núcleo Brasileiro de Estratégia e Relações Internacionais (NERINT).

Em março de 2012 o CESUL foi ampliado para abranger o conjunto geográfico do continente africano, transformando-se em CEBRAFRICA, enquanto a Série Sul-Africana, que publicou cinco livros, foi transformada em Série Africana, com novas obras no prelo. O objetivo segue sendo o mesmo: realizar pesquisas, apoiar a elaboração de teses, dissertações e trabalhos de conclusão, congregar grupos de pesquisa em temas africanos, realizar seminários, promover intercâmbio de professores e estudantes e estabelecer redes de pesquisa e projetos conjuntos com instituições africanas e africanistas, publicar obras produzidas no Brasil ou traduzidas e ampliar a biblioteca especializada fornecida pela FUNAG.

As pesquisas têm por objetivo o conhecimento do continente africano e de suas relações com o Brasil, nas seguintes áreas: Relações Internacionais, Organizações de Integração, Segurança e Defesa, Sistemas Políticos, História, Geografia, Desenvolvimento Econômico, Estruturas Sociais e sua Transformação e Correntes de Pensamento. São parceiros do CEBRAFRICA conceituadas instituições do Brasil, Argentina, Cuba, México, Canadá, África do Sul, Angola, Moçambique, Senegal, Cabo Verde, Egito, Nigéria, Marrocos, Portugal, Reino Unido, Holanda, Suécia, Rússia, Índia e China. As pesquisas em andamento versam sobre a "A presença do Brasil, da China e da Índia na África”, "A África na Cooperação Sul-Sul”, "Conflitos africanos", "Integração e desenvolvimento na África”, "As relações da África com as Grandes Potencias" e "As relações interafricanas". 


\section{NORMAS DE SUBMISSÃO}

I. A revista AUSTRAL publica artigos científicos e resenhas bibliográficas;

2. A revista está dividida em duas seções: Artigos e Resenhas

3. Os artigos de pesquisa devem limitar-se a 70 mil caracteres (incluindo espaços e notas de rodapé) e as resenhas bibliográficas devem conter cerca de 4,5 mil caracteres (incluindo espaços) e não devem conter notas de rodapé;

4. As notas de rodapé restringem-se a esclarecimentos adicionais ao texto;

5. A bibliografia deve ser citada de acordo com o sistema Chicago (Autor-data ou notabibliografia), referenciando a literatura citada ao final do texto;

6. As contribuições devem ser inéditas e podem ser submetidas em português, inglês ou espanhol;

7. As contribuições devem conter o nome completo do autor, sua titulação, filiação institucional (com o nome completo da instituição) e e-mail para contato;

8. O completo preenchimento, pelo(s) autor(es), do formulário de submissão do artigo é imprescindível;

9. Admite-se a publicação de estudantes de graduação, desde que em parceria com um professor orientador titulado, que constará como autor principal do trabalho.

Io. No caso de resenhas bibliográficas, devem ser informados os dados completos e o ISBN da obra analisada;

II. As contribuições devem vir acompanhadas de: 3 palavras-chave em português ou espanhol e 3 palavras-chave em inglês; Título em português ou espanhol e em inglês; Resumo em português ou espanhol e Abstract em inglês, ambos com até 50 palavras. I2. As contribuições devem ser feitas através do website da Revista: www.seer.ufrgs.br/Austral.

\section{CONDIC̣ÕES PARA SUBMISSÃO}

Como parte do processo de submissão, os autores são obrigados a verificar a conformidade da submissão em relação a todos os itens listados a seguir. As submissões que não estiverem de acordo com as normas serão devolvidas aos autores.

I. A contribuição é original e inédita, e não está sendo avaliada para publicação por outra revista; caso contrário, deve-se justificar em "Comentários ao editor".

2. Os arquivos para submissão estão em formato Microsoft Word, OpenOffice ou RTF (não possuindo tamanho maior do que $2 \mathrm{MB}$ )

3. URLs para as referências foram informadas quando possível.

4. O texto está em espaço simples; usa fonte Times New Roman de I2-pontos; emprega itálico em vez de sublinhado (exceto em endereços URL); as figuras e tabelas estão inseridas no texto, não no final do documento, como anexos.

5. O texto segue os padrões de estilo e requisitos bibliográficos descritos em Diretrizes para Autores, na página Sobre a Revista.

6. Em caso de submissão a uma seção com avaliação pelos pares (ex.: artigos), as instruções disponíveis em Assegurando a avaliação pelos pares cega foram seguidas. 


\section{NÚMEROS ANTERIORES}

Disponíveis online em: www.seer.ufrgs.br/Austral

Volume 1, Número 1 (Jan./Jun. 2012)

- Apresentação (Celso Amorim)

- Editorial (Paulo Fagundes Visentini)

- 0 futuro do Mercosul (Samuel Pinheiro Guimarães)

- O Brasil de Lula: uma diplomacia global e afirmativa (2003-2010) (Paulo Fagundes Visentini)

- A virada russa para a América Latina (Yuri Paniev)

- Reordenando as Relações Internacionais: o Fórum de Cooperação ChinaÁfrica (Mamoudou Gazibo, Olivier Mbabia)

- A Política Externa do governo Jacob Zuma: associação ou dissociação? (Chris Landsberg)

- Cooperação Sul-Sul e a mudança de papel dos Estados do Golfo (Kristian Coates Ulrichsen)

- A crise financeira e a hegemonia do dólar (Marcelo Milan)

\section{Volume 1, Número 2 (Jul./Dez. 2012)}

- Editorial (Paulo Fagundes Visentini)

- Apresentação (Amado Luiz Cervo)

- As Lições da Experiência do Euro (Richard Griffiths)

- O Brasil na Atual Ordem Mundial (Amado Luiz Cervo)

- Neodesenvolvimentismo e a Busca de uma nova Inserção Internacional (Giorgio Romano)

- 0 Ensino e a Pesquisa sobre Política Externa no campo das Relações Internacionais do Brasil (Carlos Aurélio Pimenta de Faria)

- O Brasil diante da Ascensão Chinesa: os Riscos da Especialização Regressiva (André Cunha, Marcos Lélis, Julimar Bichara e Manuela de Lima)

- O Impacto da Crise Internacional no Comércio do Brasil com os BRICS (Rússia, Índia, China e África do Sul) (André Luiz Reis da Silva, Luiza Peruffo)

- A Mídia e a Política Externa no Brasil de Lula (Guilherme Casarões)

- Desenvolvendoa partir doSul: CooperaçãoSul-Sulnojogo de Desenvolvimento Global (Sean Burges) 
- Da Globalização Colonial à Pós-Globalização Colonial: 0 Não alinhamento e Cooperação Sul-Sul (Aditya Mukherjee)

Volume 2, Número 3 (Jan./Jun. 2013)

- Editorial (Paulo Fagundes Visentini)

- Poder Militar, Crise Financeira e o Panorama de Segurança Internacional no Século XXI (Érico Esteves Duarte)

- Más Allá del Crimen Organizado: La Reformulación del Concepto de Insurgencia y su Impacto en el Entorno Estratégico Sudamericano (Mariano César Bartolomé)

- África do Sul, Atlântico Sul e a Equação IBAS-BRICS: o Espaço Transatlântico em Transição (Francis Kornegay)

- Amazônia Azul: Pensando a Defesa do Território Marítimo Brasileiro (Marianne L. Wiesebron)

- Um Passo para Frente, Dois para Trás: Sucesso e Fracasso na Recente Política Externa Turca (Ilter Turan)

- Incidencias de la Primavera Árabe en el Fín de la “Era Verde” en Líbia: Cuestiones Sobre Derecho de Intervención y Deber de Injerencia (Gladys Lechini, Norma S. Rabbia)

- Cooperação Sul-Sul: a Parceria Brasileira com Moçambique e a Construção de uma Fábrica de Medicamentos de combate à AIDS (Maj-Lis Follér)

- O Valor do Conceito de Hegemonia para as Relações Internacionais (Luiz Augusto Estrella Faria)

- Pensando Criticamente a Economia Política Global: Apontamentos para o Estudo de Potências Médias Emergentes. (Leonardo Ramos)

- A Implementação da Lei Internacional Anti-Corrupção no Comércio: o Controle Legal da Corrupção Dirigido às Empresas Transnacionais (Luciano Vaz Ferreira, Fabio Costa Morosini)

Volume 2, Número 4 (Jul./Dez. 2013)

- Editorial: Brasil, o Elo Mais Fraco dos BRICS? (Paulo Fagundes Visentini)

- Perspectivas Brasileiras na Convergência entre o SISBIN e a ZOPACAS (Sérgio Gonçalves de Amorim)

- O Atlântico Sul, a África Austral e a América do Sul: Cooperação e Desenvolvimento (Analúcia Danilevicz Pereira)

- As Relações Brasil-África no Campo de Segurança e Defesa 
(Sérgio Luiz Cruz Aguilar)

- O Banco Central do Brasil como Agente das Relações Internacionais (Mauro Salvo)

- Fome Zero para o Mundo: a Difusão Global Brasileira do Programa Fome Zero (Markus Fraundorfer)

- A Cooperação Técnica Triangular do Inmetro (Leonardo Pace Alves)

- En las Entrañas de los BRIC: Análisis de la Naturaleza Semiperiférica de Brasil, Rusia, Índia y China (Daniel Efrén Morales Ruvalcaba)

- Política Exterior Latinoamericana y la Comunidad de Estados Latinoamericanos y Caribeños (Elsa Llenderrozas)

- Las Potencias Medias en la Arquitectura Climática Global: la Hibridación de la Brecha Norte-Sur (María del Pilar Bueno)

- Geografia e Potencial Marítimo de China e Irã (Sören Scholvin, Alexandr Burilkov)

\section{Volume 3, Número 5 (Jan./Jun. 2014)}

- Editorial (Paulo Fagundes Visentini)

- Poder Estrutural sobre Estados Fracos: a França, e não a China, importa para a África Francófona (Olivier Mbabia)

- África e as Potências Emergentes: o Sul e a Cooperação Profana (Paulo Fagundes Visentini)

- O Papel da Segurança fornecida comercialmente no Complexo Patrimonial de Segurança Africano (Christopher Kinsey, Andreas Krieg)

- Guerra Assimétrica: Experiências, Perspectivas, Ideias e Desafios com Foco no Zimbábue (Raymond Mharapara, Lucky Bassie Bangidza, Steven Gwekwerere)

- Visando à Redefinição da Pauta de Notícias na Mídia Nigeriana para o Desenvolvimento Nacional (Osakue Stevenson Omoera)

- Exército Nacional e Construção do Estado na África: A Abordagem Brasileira no Caso da República Democrática do Congo

(Igor Castellano da Silva, José Miguel Quedi Martins)

- Política Externa da Nova África do Sul: Reinserção e Afirmação Regional (Kamilla Raquel Rizzi, Nathaly Xavier Schütz)

- Cooperação e Conflito: as Dinâmicas do Petróleo e do Gás Natural na Ásia Central (Paulo Duarte)

- El rol político de Estados Unidos en el default de Argentina (Roberto Miranda)

- Nova Política Externa Independente, uma Questão de Ênfase (Eduardo Brigidi de Mello) 
Volume 3, Número 6 (Jul./Dez. 2014)

- Editorial: A Guerra Econômica e o Silêncio da Academia (Paulo Fagundes Visentini)

- As Relações Bilaterais Brasil-Estados Unidos no Governo Dilma Rousseff, 2011-2014 (Cristina Soreanu Pecequilo)

- O Retorno da Geopolítica: A Ascensão dos BRICS (Ronaldo Carmona)

- Da Política de Contenção à Reemergência: A Rússia volta ao Tabuleiro (Diego Pautasso)

- A China também olha para o Ártico (Alexandre Pereira da Silva)

- O Programa Nuclear da África do Sul do Apartheid e seu Impacto na África Austral (Jo-Ansie van Wyk)

- El Planeamiento Estratégico Militar en la Argentina (2003-2013): Reflexiones en torno al Gobierno Político de la Defensa (Luciano Anzelini, Iván Poczynok)

- Seguridad Cooperativa: La Construcción de Medidas de Confianza Mutua con Brasil en Tiempos de Democracia Argentina (Gisela Pereyra Doval, Miguela Varela)

- Na Sombra do Império: Refletindo sobre a Posição Estratégica de Estados Pequenos na Europa e na Bacia do Caribe durante a Guerra Fria (Mitchell Belfer)

- A Inovação e o Fenômeno Bélico (Lucas Pereira Rezende, Rafael Ávila)

- La Argentina ante la Disputa entre Palestinos e Israelíes: un Estudio respecto al Posicionamiento asumido por la Administración Alfonsín (1983-1989) (Ornela Fabani) 
